UNIVERSIDADE DE SÃO PAULO

INSTITUTO DE GEOCIÊNCIAS

\title{
ANÁLISE ESTRUTURAL DOS ENXAMES DE DIQUES MÁFICOS EOCRETACEOS DO SUL-SUDESTE DO BRASIL
}

\author{
Carlos Libório de Barros Tomba \\ Orientador: Prof. Dr. Claudio Riccomini \\ DISSERTAÇÃO DE MESTRADO
}

Programa de Pós-Graduação em Geoquímica e Geotectônica 


\title{
UNIVERSIDADE DE SÃO PAULO \\ INSTITUTO DE GEOCIÊNCIAS
}

\section{ANÁLISE ESTRUTURAL DOS ENXAMES DE DIQUES MÁFICOS EOCRETACEOS DO SUL-SUDESTE DO BRASIL}

\author{
Carlos Libório de Barros Tomba \\ Orientador: Prof. Dr. Claudio Riccomini \\ Dissertação de mestrado apresentada ao Instituto de \\ Geociências da Universidade de São Paulo para \\ obtenção do grau de mestre em Geotectônica
}

DISSERTAÇÃO DE MESTRADO

Programa de Pós-Graduação em Geoquímica e Geotectônica 


\section{FICHA CATALOGRÁFICA}

Tomba, Carlos Liborio de Barros (2012)

TíTULO

ANÁLISE ESTRUTURAL DOS ENXAMES DE DIQUES MÁFICOS EOCRETACEOS DO SUL-SUDESTE DO BRASIL

No de páginas: 133; $\mathrm{N}^{\circ}$ de ilustrações: 29; $\mathrm{N}^{\circ}$ de Quadros e Tabelas: 05.

DISSERTAÇÃO DE MESTRADO-IGC/USP

ORIENTADOR: PROF. DR. CLAUDIO RICCOMINI

PALAVRAS CHAVE:

1.Diques; 2.Província Paraná-Etendeka; Formação Serra Geral; 3. Oceano Atlântico Sul; Eocretaceo; 4. Pré-sal 


\section{AGRADECIMENTOS}

Primeiramente gostaria de agradecer ao professor Claudio Riccomini pela orientação, apoio e liberdade para o desenvolvimento deste trabalho.

Ao Serviço Geológico do Brasil, em especial à Viviane Carrillo Ferrari gerente da GEREMI-SP, pelo apoio incondicional para a conclusão desta dissertação.

Ao Professor Antonio Romalino Santos Fragoso Cesar, meu preceptor, pelos ensinamentos, amizade e principalmente pela companhia nos trabalhos de campo em Santa Catarina e pela leitura crítica da dissertação.

Ao Professor Valdecir Janasi, pela ajuda e discussões sobre os aspectos petrológicos e geocronológicos da Província Magmática Paraná-Etendeka.

Aos professores Marcos Egydio Silva e Ginaldo Campanha pelas discussões sobre geologia estrutural.

Aos professores Darcy Svizero e Hans Schorcher pelos excelentes cursos de pósgraduação e pelos conhecimentos transmitidos.

Aos amigos Ricardo Bertoncello e Thayná pela hospedagem e companhia durante o primeiro trabalho de campo em São Sebastião.

Á amiga Melina Leite e sua família pela hospedagem e companhia durante os trabalhos de campo entre Angra dos Reis e Paraty. Por todo carinho e amizade e pelos incontáveis artigos "baixados".

Ao amigo Guilherme Schroeder pela companhia e hospedagem durante os trabalhos de campo em Santa Catarina.

Ao amigo Enos Nobuo Sato pela companhia desde a graduação, pelas discussões geológicas e das coisas da vida. Agradeço também pela ajuda fundamental nas análises estatísticas desta dissertação.

Ao Fabrizzio Caltabelloti pela ajuda com o ArcGis.

À minha mais querida e especial amiga Maria Elisa Moura pela leitura e correção do abstract.

Aos funcionários da gráfica do IGc-USP, especialmente para o Henrique, Sr. Zé e Claudionor. Também gostaria de agradecer as secretárias de Pós-graduação Ana Paula e Magali e as bibliotecárias Brenda e Érica. 
Aos colegas de trabalho da CPRM, especialmente Sérgio Estevam, Roy, Claudia, Mislene, Vilmário, Mauro, Vitório e Viviane pela convivência.

Aos antigos colegas de GME4, especialmente ao Ricardo Barbosa, Eliseu, Ivair, Luis Luna, Rogério Matos, Bruno Fernandes, Danilo Ragazzi, Guilherme Rampazzo, Júnior, Tânia e Sr. Clodoaldo. Agradecimentos especiais à equipe do Projeto Bahia-Piauí, Paulo Haddad, Valter Mônaco, e Antonio Carlos Santos (Tim Maia).

Aos antigos amigos do Centro de Pesquisa Leopoldo Américo Miguez de Mello (CENPES): João Bosco, Anderson Moraes, Claudio Lima, Gabriel, Paulo Santarém, Jorge Mendonça, Antonio Palermo, Luis Alberto, Luis Felipe, Antonio Carlos, José Eduardo, Armando Prestes, Mário Villas-boas e todos os amigos do Fórum Transverso.

Aos amigos da Geo: Delano, Falcon, Trilô, Fernanda Quaglio, Banheirão, Cofrinho, Melado, Vinícius Tieppo, Gustavo Abreu, Cotoco, Xava, Sarah, Cláudia, Mimoso, Sinistro, e a todos que ficarão faltando, pela amizade e companhia no estudo das rochas.

Aos amigos e amigas de todos os dias: Maria Elisa Moura, Juliana Campoy, Cintia Acayaba, Enos Sato, Tiago Gouveia (Gominho), Silas Gubitoso, Edson Yoshio (Opção), Juliano Paccez, Érico, Fernando Domenico e Eleonora, Daniela Almenara, Maira Neves, Giacomo Favili, Thaís, Melina, MBS, Roque, Fernando, Fábio, Kiwi, Pedro Octaviano, Domingos Octaviano e a todos os outros que esqueci.

Agradeço aos meus pais: Mara e Carlos Roberto, e ao meu irmão Augusto pelo apoio e companhia.

E finalmente a Bruna Octaviano pelo apoio, compreensão e carinho em todos os momentos. 

Fui instruído nas letras desde a infância, e por me haver convencido de que, por intermédio delas, poder-se-ia adquirir um conhecimento claro e seguro de tudo o que é útil à vida, sentia extraordinário desejo de aprendê-las. Porém, assim que terminei esses estudos, ao cabo do qual costuma-se ser recebido na classe dos eruditos, mudei totalmente de opinião. Pois me encontrava embaraçado com tantas dúvidas e erros que me parecia não haver conseguido outro proveito, procurando instruir-me, senão o de ter descoberto cada vez mais a minha ignorância.

\author{
René Descartes
}




\section{RESUMO}

A abertura do Oceano Atlântico Sul durante o Eocretaceo está registrada na Plataforma Continental da América do Sul em derrames de basaltos continentais, enxames de diques máficos e bacias do tipo rift. Uma revisão do estado de conhecimento sobre os aspectos estruturais, tectônicos e geocronológicos dos enxames de diques máficos do Sul-Sudeste do Brasil foi tema de estudo desta dissertação. Análises estruturais realizadas em afloramentos nos enxames de diques Santos-Rio de Janeiro), Ponta Grossa e Florianópolis indicaram que a intrusão desses corpos ocorreu na crosta aproveitando sempre estruturas pré-existentes do embasamento rúptilmente deformado em eventos anteriores. Os Enxames de diques do Sul-Sudeste do Brasil marcam o início do processo de rifteamento e tendem a acompanhar as bordas ou truncar transversalmente o rift . Os diques podem ser utilizados como indicadores da direção do esforço principal mínimo ( $\sigma 3)$, bem como da direção de estiramento crustal. Estudos realizados no Enxame de Diques Santos-Rio de Janeiro, de direção geral NE-SW, indicaram que a intrusão na crosta ocorreu em condições rúpteis onde $\sigma 3$ era horizontal e orientado na direção geral NW-SE. No Enxame de Diques Florianópolis, com direção geral NNE-SSW, os estudos realizados indicaram que a intrusão também ocorreu em condições rúpteis da encaixante, onde $\sigma 3$ estava orientado na direção WNW-ESE, horizontal. O Enxame de Diques de Ponta Grossa de direção NW-SE, também se alojou na crosta em condições rúpteis, onde $\sigma 3$ estava orientado na direção NE-SW, igualmente horizontal. Análises estatísticas de 367 datações radiométricas do Magmatismo Serra Geral (derrames e enxames de diques), envolvendo as sistemáticas isotópicas $\mathrm{K}-\mathrm{Ar}$, $\mathrm{Ar}-\mathrm{Ar}$ e U-Pb indicaram que a sistemática U-Pb é a mais precisa e exata. Embora existam apenas 06 dados disponíveis na bibliografia (U-Pb 04 SHRIMP; 02 TIMS), estes definem uma idade mínima de $\sim 134$ Ma. No caso dos enxames de diques, as datações disponíveis não são precisas suficientes para estabelecer qualquer relação cronológica entre os enxames. Os resultados desta dissertação corroboram estudos anteriores realizados desde a década de 1940 por pioneiros da Geologia do Brasil, destacando Victor Leinz, Moraes Rego, Fernando Flávio Marques de Almeida, Eduardo Damasceno, José Moacyr Vianna Coutinho e Gilberto Amaral. A revisão bibliográfica feita sobre o tema demonstra a importância dos trabalhos destes autores no tema de estudo. 


\begin{abstract}
The opening of the South Atlantic Ocean during the Early Cretaceous is recorded on the continental shelf of South America in floods of continental basalts, mafic dyke swarms and rift basins. A review of the state of knowledge about the structural, tectonic and geochronological data of mafic dyke swarms of South-East Brazil was the subject of this dissertation. Structural analyzes performed on outcrops on the dyke swarms of Santos-Rio de Janeiro, Ponta Grossa and Florianopolis showed that these bodies intruded the crust through pre-existing brittle and ductile structures of the basement deformed in previous events. The dyke swarms of South-East Brazil, that marked the beginning of the rifting process, tend to follow the edges or truncate across the rift borders. Dykes can be used as indicators of the direction of least principal stress $(\sigma 3)$ as well the direction of crustal stretching. Studies in NE-SW Santos-Rio de Janeiro Dyke Swarm, indicated that the intrusion occurred in brittle conditions was $\sigma 3$ horizontal and oriented in NW-SE direction. The NNE-SSW Florianopolis Dyke Swarm also indicated that the intrusion occurred under brittle conditions of the host rocks, where $\sigma 3$ was oriented in WNW-ESE direction and horizontal. The NW-SE Ponta Grossa Dyke Swarm also intruded the host rock under brittle conditions where $\sigma 3$ was oriented NE-SW direction also horizontal. Statistical analysis of 367 radiometric ages of the Serra Geral Magmatism (lavas, dike swarms and sills), involving the K-Ar, Ar-Ar and U-Pb systematics indicate that the $\mathrm{U}-\mathrm{Pb}$ is the most precise and accurate. Although there are only 06 available data in the literature (04 U-Pb SHRIMP, TIMS 02), they define a minimum age of $\sim 134$ Ma. For the dike swarms, the available radiometric data are not precise enough to establish any chronological relation between the swarms. The results of this work confirm previous studies conducted since the 1940s by pioneers of brazilian Geology, highlighting Victor Leinz, Moraes Rego, Fernando Flavio Marques de Almeida, Eduardo Damasceno, José Vianna Moacyr Coutinho and Gilberto Amaral. The literature review that was done on the subject demonstrates the importance of these authors for this study.
\end{abstract}




\section{SUMÁRIO}

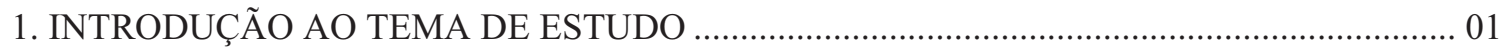

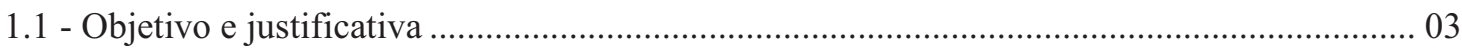

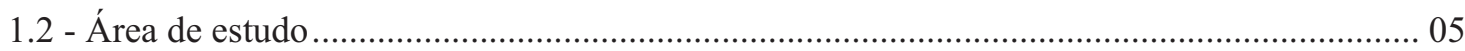

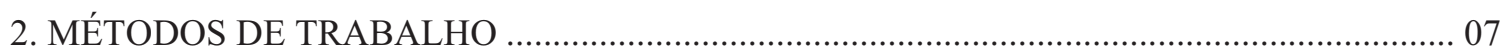

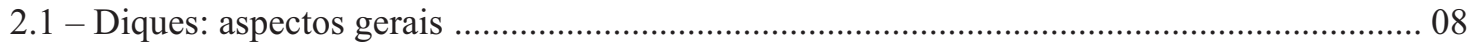

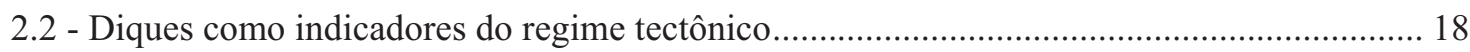

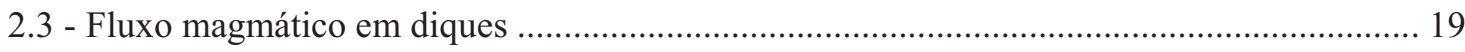

3. SIGNIFICADO GEODINÂMICO DE ENXAMES DE DIQUES ……......................................... 22

3.1 - A importância de Sir Arthur Holmes (1890-1965) no tema de estudo ................................... 27

3.2 - Rifts, grandes províncias ígneas, hot spots e plumas do manto ………………………….... 29

4. O MAGMATISMO EOCRETACEO E A ABERTURA DO OCEANO ATLÂNTICO SUL ..... 42

4.1 - A Formação Serra Geral: definição e unidades cronocorrelatas na porção Sul-Sudeste da

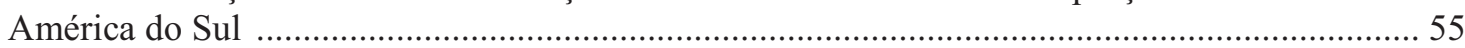

4.2 - Posicionamento crononoestratigráfico do magmatismo Serra Geral e eventos correlatos nas

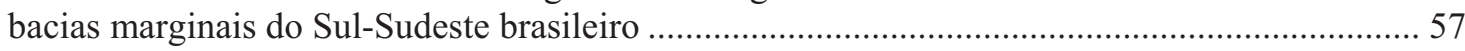

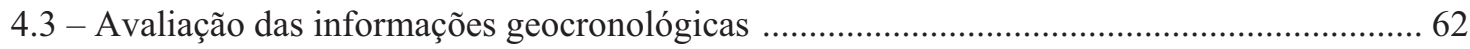

4.3.1. Discussão sobre os dados geocronológicos disponíveis na bibliografia ............................ 66

5. ENXAMES DE DIQUES MÁFICOS EOCRETACEOS NO SUL-SUDESTE DO BRASIL:

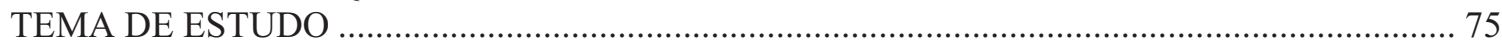

5.1 - Enxame de Diques Serra do Mar (Santos-Rio de Janeiro) ................................................... 78

5.1.1 Estudos no Enxame de Diques Serra do Mar................................................................. 80

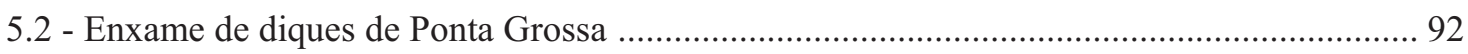

5.2.1 Estudos no Enxame de Diques de Ponta Grossa ................................................................. 96

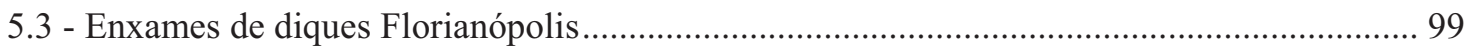

5.3.1 Estudos no Enxame de Diques de Florianópolis ................................................................ 100

6. CONSIDERAÇÕES FINAIS SOBRE A DISSERTAÇÃO …………………………................ 109

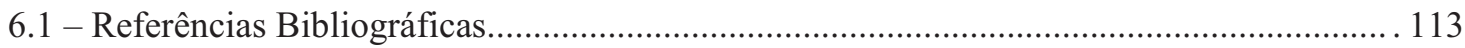




\section{ÍNDICE DE FIGURAS}

Figura 01 - Área de estudo e distribuição espacial dos enxames de diques máficos eocretaceos do Sul-Sudeste do Brasil..

Figura 02 - Modos de fraturamento aplicado aos diques, segundo Pollard (1987)....... .12

Figura 03 - Interpretação cinemática para feições de borda em segmentos de diques com terminações abruptas. Modificado de Rickwood (1990).

Figura 04 - Representação mecânica no Diagrama de Mohr das condições de ruptura e do efeito do magma na resistência das rochas encaixantes.

Figura 05 - Estágios evolutivos de enxames de diques continentais, simplificado de Fahrig (1987).

Figura 06 - Modelo esquemático demonstrando duas formas de distensão crustal, segundo Buck (2006).

Figura 07 - Modelo ilustrativo do mecanismo de "corrente de convecção" proposto por Arthur Holmes em 1929 para explicar a deriva continental e o surgimento de uma bacia oceânica.

Figura 08 - Estrutura do interior da Terra. Modificado de Bott (1971).

Figura 09 - Modelos teóricos de rifteamento. A) Rift passivo. B) Rift ativo. Segundo Şengor \& Burke (1978)......

Figura 10 - Relações temporais entre o magmatismo e o surgimento das anomalias magnéticas oceânicas (OMA) em diferentes províncias basálticas, segundo Courtillot et al. (1999)...... 36

Figura 11 - Distribuição global das províncias de basaltos continentais relacionados à ruptura do Pangea. Modificado de Coffin e Eldholm (1994).....

Figura 12 - Contexto regional do magmatismo mesozoico na região sul-sudeste do Brasil, segundo Almeida et al. (1996)...

Figura 13 - Arcos, altos estruturais, lineamentos e flexurastransversais da Bacia doParaná. Simplificado de Riccomini et al. (2005).

Figura 14 - Modelo evolutivo da Província Magmática Paraná-Etendeka durante a abertura do Oceano Atlântico Sul de acordo com Piccirillo et al. (1988)...... .48

Figura 15 - Bacias sedimentares brasileiras da Margem Continental Atlântica da América do Sul. Adaptado de Chang et al. (1992). 
Figura 16 - Distribuição espacial das datações radiométricas disponíveis para a Província Basáltica Paraná e rochas correlatas nas bacias da margem continental.

Figura 17 - Comparação da distribuição das idades radiométricas do magmatismo intrusivo e extrusivo associado à Província Magmática Paraná-Etendeka em relação à posição geográfica das amostras datadas.

Figura 18 - Comparação da distribuição das idades radiométricas por diferentes sistemáticas isotópicas de rochas ígneas vulcânicas e subvulcânicas da Província Magmática Paraná.. .72

Figura 19 - A) Variação das idades radiométricas existentes para a Província MagmáticaParaná e de unidades correlatas das bacias marginais brasileiras. B) Comparação da distribuição das idades radiométricas do magmatismo intrusivo e extrusivo associado à Província Magmática Paraná........73

Figura 20 - Cronoestratigrafia do magmatismo Serra Geral

Figura 21 - Contexto geológico regional dos enxames de diques máficos eocretaceos do SulSudeste do Brasil.

Figura 22 - A) Diagrama de rosácea representando 104 diques de diabásio entre São Sebastião e Ilhabela

Figura 23 - A) Diagrama de rosácea representando 133 diques de diabásio entre Ubatuba, Paraty e Angra dos Reis.

Figura 24 - A) Diagrama de rosácea representando 36 diques de diabásio entre Búzios-Cabo Frio...

Figura 25 - A) Diagrama de rosácea representando 72 diques de diabásio nos domínios do Arco de Ponta Grossa...

Figura 26 - A) Diagrama de rosácea representando 23 diques de diabásio entre Itajaí e Bombinhas.

Figura 27 - A) Diagrama de rosácea representando 71 diques de diabásio entre Florianópolis e Imbituba. .104

Figura 28 - Dique segmentado em zig-zag mostrando sua relação com as fraturas da rocha encaixante. 110

Figura 29 - Distribuição regional dos enxames de diques máficos eocretaceos do Sul-Sudeste do Brasil. 


\section{ÍNDICE DE QUADROS E TABELAS}

Quadro 01 - Classificação de diques segundo Rickwood (1990).....................................................

Quadro 02 - Sumário das temperaturas de fechamento do Ar em diferentes minerais....................63

Quadro 03 - Resumo estatístico dos dados geocronológicos do magmatismo Serra Geral...............66

Quadro 04 - Resumo estatístico dos dados geocronológicos do magmatismo extrusivo e intrusivo

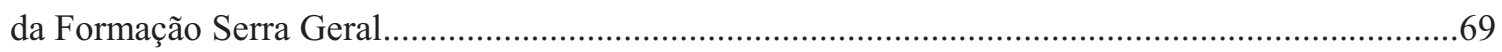

Quadro 05 - Resumo estatístico dos dados geocronológicos dos enxames de diques máficos associados à Formação Serra Geral. 


\section{CAPÍTULO I}

\section{INTRODUÇÃO AO TEMA DE ESTUDO}

Durante o Eocretaceo, na região centro-sul do Pangea, especificamente na porção correspondente à borda oriental da Plataforma Sul-Americana, ocorreu um intenso processo de rifteamento cujos principais registros geológicos são bacias sedimentares do tipo rift continental, sendo que algumas destas evoluíram para bacias oceânicas de margem passiva, acompanhadas por intenso magmatismo toleítico, representado por extensos derrames de basaltos continentais, intrusões de soleiras e enxames de diques. A análise estrutural e tectônica dos diques desses enxames é o principal objeto de estudo da presente dissertação. Para contextualizar este estudo dentro da evolução dos fenômenos geodinâmicos que culminaram com a completa ruptura da litosfera, separando os atuais continentes africano e sul-americano, serão abordados os principais conceitos estabelecidos até o momento visando fornecer um panorama geral sobre o assunto.

O estudo das relações entre o magmatismo e os rifts fornece subsídios para uma melhor compreensão dos mecanismos que iniciam e permitem o desenvolvimento dos processos de ruptura da litosfera. Tal estudo envolve, além da extensão e volume do magmatismo considerado, sua natureza composicional e seu significado tectônico no tempo e espaço. Além disso, vários exemplos de rupturas continentais registrados sugerem uma estreita relação entre magmatismo, ruptura de crosta continental e formação de crosta oceânica.

Tais manifestações magmáticas representam processos geodinâmicos do manto que se desenvolvem durante a distensão da litosfera e a consequente ruptura da crosta continental. Neste processo, magmas são transferidos do manto para a crosta superior e superfície, onde se cristalizam na forma de derrames e intrusões de enxames de diques e de soleiras. Os diques e seus enxames, posteriormente exumados, marcam os caminhos percorridos pelo magma ao atravessar a crosta. Ao longo do desenvolvimento desses eventos muitas fraturas são geradas e/ou reativadas e preenchidas por magmas 
obedecendo principalmente a direção normal à direção principal de esforço mínimo do campo de tensões regional.

Nesse quadro, a análise de enxames de diques representa uma excelente ferramenta para o entendimento das fases iniciais dos fenômenos de distensão crustal e na reconstituição do estilo tectônico e do campo de esforços atuante durante o desenvolvimento destes processos. Com o suporte de datações radiométricas a partir de sistemáticas isotópicas adequadas, tais enxames podem permitir a definição segura do intervalo de tempo da atuação desses eventos.

Na porção meridional do Brasil, e em partes do Uruguai, Paraguai e Argentina, o Eocretaceo está representado no registro geológico por um dos mais extensos derrames de lavas basálticas continentais do planeta, abrangendo uma área de cerca de 1.200.000 $\mathrm{km}^{2}$, com um volume de rocha preservado de cerca de $800.000 \mathrm{~km}^{3}$, denominado Província Magmática do Paraná (Piccirilo \& Melfi 1988), que reúne as unidades ígneas eocretáceas da Bacia do Paraná sobrepostas e intrudindo unidades sedimentares paleozoicas e mesozoicas. Os derrames desta província são reunidos na Formação Serra Geral, topo do Grupo São Bento (Gordon Jr. 1947).

A Província Magmática do Paraná é representada principalmente por derrames de basalto toleítico e, subordinadamente, por rochas efusivas de natureza ácida. Além desses derrames, houve significativa atividade magmática intrusiva, também de natureza toleítica e de composição predominantemente básica, na forma de soleiras e diques. Os diques formam enxames com direções tanto transversais (enxame de Ponta Grossa) quanto paralelas à costa atlântica (enxames de Florianópolis e Serra do Mar, também conhecido como Santos-Rio de Janeiro).

Além dos derrames da Formação Serra Geral da Bacia do Paraná, são reconhecidos, em furos de sondagens de empresas petrolíferas, derrames de mesma composição e idades em bacias da margem continental sudeste da América do Sul (e.g. Formação Imbituba; na Bacia de Pelotas, Formação Camboriú; na Bacia de Santos; Formação Cabiúnas; nas bacias de Campos e Espírito Santo).

Os enxames de diques associados à Formação Serra Geral cortam a cobertura sedimentar paleozoica e mesozoica da Bacia do Paraná. Suas principais exposições, no 
entanto, ocorrem intrudindo rochas ígneas e metamórficas do embasamento cristalino pré-cambriano, particularmente ao longo da linha de costa do sul e sudeste do Brasil.

Estes diques, tanto os costeiros (Santos-Rio de Janeiro e Florianópolis), como os transversais (Ponta Grossa) foram alvos de inúmeros trabalhos desde a década de 1960, principalmente no que diz respeito aos aspectos petrográficos petrológicos, geoquímicos e geocronológicos. Porém, somente nos últimos anos é que o significado estrutural e tectônico desses enxames, na forma de indicadores de paleocampos de esforços, vem sendo explorado (e. g. Riccomini 1995, Ferrari 2001, Silva \& Riccomini 2005, Riccomini et al. 2006, Tomba \& Sato 2006, Brentan 2006, Tomba \& Riccomini 2008).

\section{1- Objetivo e justificativa}

Os principais objetivos da presente dissertação de mestrado são a caracterização estrutural e a análise tectônica dos enxames de diques máficos da região sudeste da América do Sul, visando à elaboração de um modelo geodinâmico no contexto da ruptura da porção sul do Pangea, com a consequente abertura do rift que originou o oceano Atlântico Sul. As causas dos processos de transição entre a distensão crustal e rifteamento sem envolvimento de magmatismo, para o mesmo fenômeno envolvendo magmatismo, nem sempre são claras e normalmente são relacionadas por diversos autores à atividade de plumas do manto (e. g. Morgan 1971, Richards et al. 1989, White \& McKenzie 1989, O’Connor \& Duncan 1990, Hooper 1990, Griffiths \& Campbell 1991 Ernst et al. 1995, Ernst \& Buchan 1997, Turner et al. 1996, Hofmann et al. 1997, Hofmann et al. 2000, Courtillot et al. 1999, Campbell 2005 entre outros).

No entanto, registros dos campos de esforços atuantes à época desses eventos materializados na forma de enxames de diques, podem oferecer informações e novas perspectivas para as relações existentes entre a evolução dos campos de tensões regionais e o início e causa do magmatismo. Além disso, a partir da compilação de dados radiométricos das idades de basaltos das bacias marginais e da região emersa adjacente principalmente da Formação Serra Geral e das vulcânicas correlatas do Grupo Etendeka no continente africano, pretende-se obter uma contextualização temporal dos eventos tectono-magmáticos. 
Do ponto de vista tecnológico, o período de tempo compreendido e o contexto tectônico estudado neste trabalho representam o intervalo cronoestratigráfico correspondente à sedimentação pré-sal, onde as últimas grandes descobertas de campos de petróleo transformaram o oceano Atlântico Sul em uma nova fronteira exploratória para toda indústria petrolífera. Assim, o conhecimento da duração e extensão dos eventos magmáticos e de seu contexto tectônico é relevante para a avaliação dos sistemas petrolíferos vinculados à sedimentação pré-sal, bem como para o conhecimento dos aspectos evolutivos das bacias sedimentares da margem leste do Brasil, em especial para a fase rift destas bacias.

Desta forma, o presente trabalho pretende contribuir para o questionamento e discussão dos modelos atuais advogados para a ruptura do paleocontinente Pangea e abertura do Oceano Atlântico Sul, bem como dos eventos magmáticos relacionados a este contexto. 


\section{2 - Área de estudo}

As melhores e mais acessíveis exposições dos enxames de diques associados à Formação Serra Geral ocorrem em praias com costões rochosos ao longo do litoral sudeste sul-americano, principalmente Rio de Janeiro, norte de São Paulo, Paraná e Santa Catarina (Figura 01). Essas exposições intrudem rochas pré-cambrianas do embasamento cristalino, principalmente graníticas, gnáissicas (orto e paraderivadas) e migmatíticas, todas exibindo marcante textura milonítica geradas em contexto deformacional transcorrente (Hennies et al. 1967, Hasuy et al. 1969, Sadowski 1974).

No estado do Rio de Janeiro, a principal região de ocorrência de diques relacionados ao magmatismo cretaceo está localizada na porção centro-norte do litoral fluminense, especificamente entre os municípios de Armação dos Búzios, Cabo Frio e Arraial do Cabo. Na porção sul do litoral fluminense foram realizados trabalhos de campo na região compreendida entre os municípios de Angra dos Reis e Parati. Passando para o litoral do Estado de São Paulo, os trabalhos se concentraram na região litorânea entre os municípios de Ubatuba, Caraguatatuba e São Sebastião e, na porção insular, na ilha de São Sebastião, atual município de Ilhabela. No interior do continente, Estado de São Paulo, foram descritos diques na região de Capão Bonito-SP e Cerro Azul-PR. No Estado de Santa Catarina, os trabalhos se concentraram na costa entre os municípios de Bombinhas e Imbituba. 


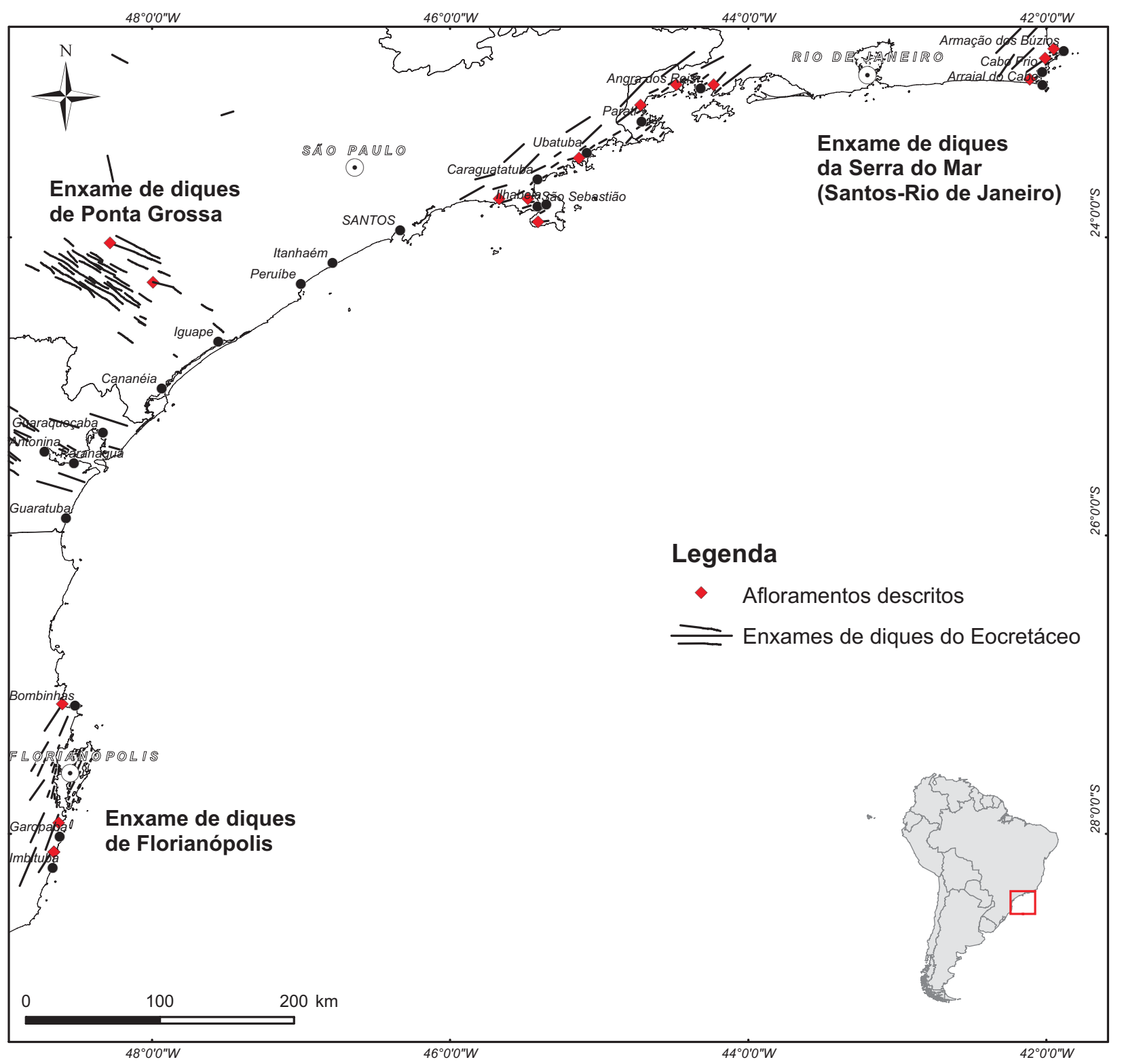

Figura o1 - Área de estudo e distribuição espacial dos enxames de diques máficos eocretaceos do Sul-Sudeste do Brasil. 


\section{CAPÍTULO II}

\section{MÉTODOS DE TRABALHO}

Para o alcance dos objetivos propostos, foram identificados e caracterizados diques de rochas ígneas máficas intrudidas em rochas do embasamento pré-cambriano aflorantes ao longo de trechos da costa dos estados de Santa Catarina, Paraná, São Paulo e Rio de Janeiro.

Dos diques estudados em trabalhos anteriores, foram compilados medidas de direção e de localização. No enxame Serra do Mar (Santos-Rio de Janeiro), os dados foram extraídos dos trabalhos de Damasceno (1966), Garda (1995), Ferrari (2001), Silva \& Riccomini (2005), Guedes (2005), Tomba \& Sato (2006), Valente et al. (2005) e Coutinho (2008). No enxame de Florianópolis, foram compilados os dados apresentados em Raposo et al. (1998), Brentan (2006), Coutinho (2008) e Tomazzoli \& Pellerin (2008). Na região do Arco de Ponta Grossa foram utilizados dados levantados anteriormente por Fúlfaro \& Suguio (1967), Raposo (1995ª) Machado Junior (2000) e Coutinho (2008). Desse modo, pretendeu-se obter um quadro regional da distribuição de diques e dos campos de esforços atuantes durante a época de colocação desses enxames.

Os diques estudados tiveram suas atitudes medidas (direção e mergulho), espessura e comprimento aflorante mínimo quantificados. Os contatos entre os diques e as rochas encaixantes foram descritos detalhadamente, uma vez que nesses locais encontram-se os principais indicadores cinemáticos necessários ao tipo de análise proposta, tais como: pontes, chifres, degraus, escalonamento de diques, falhas sinmagmáticas e foliações internas oblíquas usando os critérios sintetizados em Pollard (1987) e Rickwood (1990) discutidos no contexto adequado desta dissertação. Também foi dada especial atenção a indicadores primários de fluxo magmático, como estrias, elongação de vesículas isorientadas, rincle marks, scour marks, fingers marks, dobras de arrasto, elongação e assimetria de fenocristais conforme proposta de Côrrea-Gomes et al. (1996).

Para uma melhor definição do intervalo de tempo envolvido durante a intrusão destes enxames de diques na crosta, foram compiladas e recalculadas praticamente todas 
as idades ${ }^{40} \mathrm{~K} /{ }^{39} \mathrm{Ar},{ }^{40} \mathrm{Ar} /{ }^{39} \mathrm{Ar}$, além de idades $\mathrm{U}-\mathrm{Pb}$, obtidas em rochas vulcânicas extrusivas e intrusivas associadas ao magmatismo Serra Geral. Além disso, foi também realizado um estudo estatístico baseando-se na distribuição das idades visando uma melhor definição do intervalo de tempo envolvido.

\section{1 - Diques: aspectos gerais}

Diques são corpos planares normalmente com geometria tabular formados na maioria dos casos por rochas ígneas intrusivas, salvo os casos de diques clásticos. De um modo geral, expõem-se na superfície na forma de parede ou muro, justificando a denominação de "dique". Representam uma das formas de intrusão magmática rasa mais comum na natureza e podem ser considerados os principais condutos de transporte de magmas para níveis superiores da crosta, inclusive para a superfície (Holmes 1944).

Geralmente estes corpos apresentam uma relação média entre comprimento/largura máxima 1000:1, e mínima de 200:1 (Rickwood 1990), costumam apresentar mergulhos elevados e, como regra, são discordantes das estruturas das rochas encaixantes (Suppe 1985).

Os conceitos discordante e concordante, respectivamente para o caso de diques e soleiras, só se aplica em bacias sedimentares ou vulcanossedimentares que não apresentam deformações acompanhadas por forte basculamento das rochas encaixantes, como exemplificado pelos depósitos pré-cretaceos da Bacia do Paraná. No presente estudo, onde os diques investigados intrudem rochas graníticas ou migmatíticas, esses conceitos não são aplicáveis. Nesses casos é mais adequado tratar diques como intrusões planares subverticais.

Os diques podem ser classificados em função das suas dimensões (comprimento e espessura) observadas no plano horizontal, conforme os termos descritos no Quadro 1 . 
Quadro 1 - Classificação de diques segundo Rickood (1990).

\begin{tabular}{|l|l|l|}
\hline \multicolumn{1}{|c|}{ Nomeclatura } & \multicolumn{1}{c|}{ Largura } & \multicolumn{1}{c|}{ Comprimento } \\
\hline Microdique & $<1 \mathrm{~cm}$ & $<2 \mathrm{~m}$ \\
\hline Minidique & $1-10 \mathrm{~cm}$ & $2-20 \mathrm{~m}$ \\
\hline Dique & $0,1-50 \mathrm{~m}$ & $0,1-50 \mathrm{~km}$ \\
\hline Macrodique & $50-250 \mathrm{~m}$ & $50-250 \mathrm{~km}$ \\
\hline Megadique & $>250 \mathrm{~m}$ & $>250 \mathrm{~km}$ \\
\hline
\end{tabular}

A classificação de diques proposta por Rickwood (1990), por motivos óbvios, leva em consideração apenas aspectos bidimensionais. Cañón-Tapia (2007) discute o grau de dificuldade e incerteza existente para se determinar a estrutura em três dimensões de um dique. O maior problema está relacionado principalmente à dificuldade de se encontrar boas exposições de diques onde sua continuidade em profundidade pode ser observada e quantificada.

De fato, existem algumas maneiras de se estimar a profundidade de um dique a partir de suas dimensões 2D, normalmente com maior expressão no plano horizontal do que vertical (Rickwood 1990, Cañón-Tapia 2008). Baseando-se em modelos numéricos construídos a partir dos conceitos da Teoria da Elasticidade (Lei de Hooke), os diques podem apresentar uma variação da ordem de $10^{2}$ a $10^{4}$ em sua razão comprimento/largura (Pollard 1987, Maaløe 1998). Assim, assumindo que o comprimento de um dique é tão longo quanto sua dimensão vertical, podemos extrapolar que diques de grande comprimento em superfície possam ter ascendido de grandes profundidades, aprisionando muitas vezes xenólitos de rochas mantélicas comumente encontrados em diques de rochas máfico-ultramáficas (Cañón-Tapia 2008).

Em ambientes geológicos favoráveis à ocorrência de processos de fusão parcial da crosta continental e/ou do manto superior, diques e enxames de diques representam elementos facilitadores da drenagem do líquido magmático gerado (McKenzie 1984).

Os mecanismos de alojamento de diques máficos na crosta é ainda um assunto muito debatido. Existe certa discussão se a colocação de diques ocorre em fraturas préexistentes ou se o alojamento e a propagação do dique geram sua própria fratura. $\mathrm{O}$ fato da crosta superior ser repleta de fraturas e falhas suporta a ideia que diques possam ocupar de forma passiva fraturas preexistentes. Esta relação foi demonstrada em diversos trabalhos (e. g. Currie \& Ferguson 1970, Billings 1972, Bahar \& Girod 1983, 
Becaluva et al. 1983, Delaney et al. 1986, Mège et al. 2004, Le Gall et al. 2005, Jourdan et al. 2006).

Por outro lado, experimentos analíticos envolvendo conceitos da Mecânica de Rochas, ao aproximarem a geometria de diques para corpos elípticos elongados, demonstram que a tensão concentrada ao redor da ponta do dique é suficientemente grande para fraturar a rocha encaixante mesmo sob baixas pressões de magma (Atkinson 1987).

De um modo geral, a direção de alojamento de um dique depende do balanço de esforços entre a pressão do magma e o campo de tensões regional vigente durante o momento de colocação. Assim, a atitude de diques pode ser utilizada como indicadora da orientação do campo de esforços atuante durante a época de seu alojamento. A formação de um dique ocorre quando um magma sob pressão é forçado a abrir caminho na crosta através da propagação de uma fratura. Esta avança através de processos de fraturamento hidráulico da rocha em que o magma está atravessando. Para que ocorra a propagação do dique, é necessário que a tensão aplicada na direção perpendicular à direção da fratura seja menor que a pressão do magma. Ao mesmo tempo, para que ocorra a abertura de uma fratura, a tensão normal atuante no plano da descontinuidade deve ser obrigatoriamente menor do que a pressão de fluido atuante (Jolly \& Sanderson 1996). Cabe lembrar que essa condição é válida apenas para a crosta rúptil.

Assim, muitos autores sugerem que diques alojam-se na crosta perpendicularmente à direção do eixo de menor esforço, $\sigma 3$, sendo esta correspondente à direção de abertura da fratura, também conhecida como dilatação ou estiramento (Stevens 1911, Anderson 1951, Odé 1957, Pollard 1987, Zoback et al. 1989, Zoback 1992, entre outros). Esta relação também apresenta certa validade para corpos intrusivos de forma elíptica, onde muitos autores observam uma relação entre a direção do eixo de maior elongação desses corpos com a direção do eixo principal de mínimo esforço $\sigma 3$ (Nakamura 1977, Bosworth et al. 2000).

A partir de relações observadas entre diques e fraturas no Platô do Colorado, Delaney et al. (1986) concluem que ambas situações descritas acima podem ocorrer. No entanto, os autores demonstram que dependendo do ângulo entre a fratura e a direção do esforço principal mínimo $(\sigma 3)$, diques podem preencher fraturas pré-existentes em direções favoráveis à abertura em condições onde a diferença entre o esforço horizontal 
máximo $\left(\mathrm{Sh}_{\max }\right)$ é pequena quando comparada com a pressão dirigida exercida pelo magma. Nesses casos diques e/ou enxames de diques representam indicadores de esforços duvidosos sendo necessário recorrer a outros indicadores. Os autores alertam que este tipo de situação pode ocorrer em regiões onde as tensões horizontais são menores que a tensão vertical exercida pela gravidade, situação típica de regiões intraplaca.

$\mathrm{Na}$ maioria dos casos, diques não apresentam uma geometria tabular plana com paredes perfeitamente paralelas, mas sim uma série de segmentos aparentemente desconectados, dependendo do nível de erosão observado, com formas em lâminas (blade like dikes), conforme descritos em Nicholson \& Pollard (1985) e Rubin \& Pollard (1987). No entanto, Delaney \& Pollard (1981) observam que é possível que estes segmentos estivessem conectados pelo menos durante o momento de injeção do magma na crosta.

Variações na morfologia tabular de diques decorrem do estado de tensões da rocha encaixante, da pressão de fluido do magma e principalmente da presença de fraturas pré-existentes. O campo de tensões e a pressão de fluido determinam as características mecânicas do fraturamento formado através da propagação do dique, enquanto as condições de pressão e temperatura determinam o contraste reológico entre o magma e a rocha encaixante (Pollard 1987, Bussel 1989).

Variações na morfologia de diques podem ocorrer em função das características da fratura formada durante a propagação do dique (Pollard 1987). São descritos três modos de ruptura em função da variação do eixo de esforço principal mínimo $\left(\sigma_{3}\right)$, sendo elas fraturas do Modo Puro I, fraturas do Modo Misto I-II e fraturas de Modo Misto I-III (Figura 02). No caso das fraturas do Modo Puro I, o eixo de esforço principal mínimo $\left(\sigma_{3}\right)$ apresenta orientação constante, resultando em um dique planar e trajetória de propagação retilínea. Para as fraturas do Modo Misto I-II, ocorre uma rotação do eixo de esforço principal mínimo $\left(\sigma_{3}\right)$ em torno de um eixo paralelo à direção do dique, produzindo um dique curvilíneo. No caso das fraturas do Modo Misto I-III, a rotação do eixo de esforço principal mínimo $\left(\sigma_{3}\right)$ se dá em torno de um eixo perpendicular à direção do dique, produzindo um dique com arranjo escalonado. Fraturas de modo misto tendem a exibir trajetórias de propagação curvilíneas. 

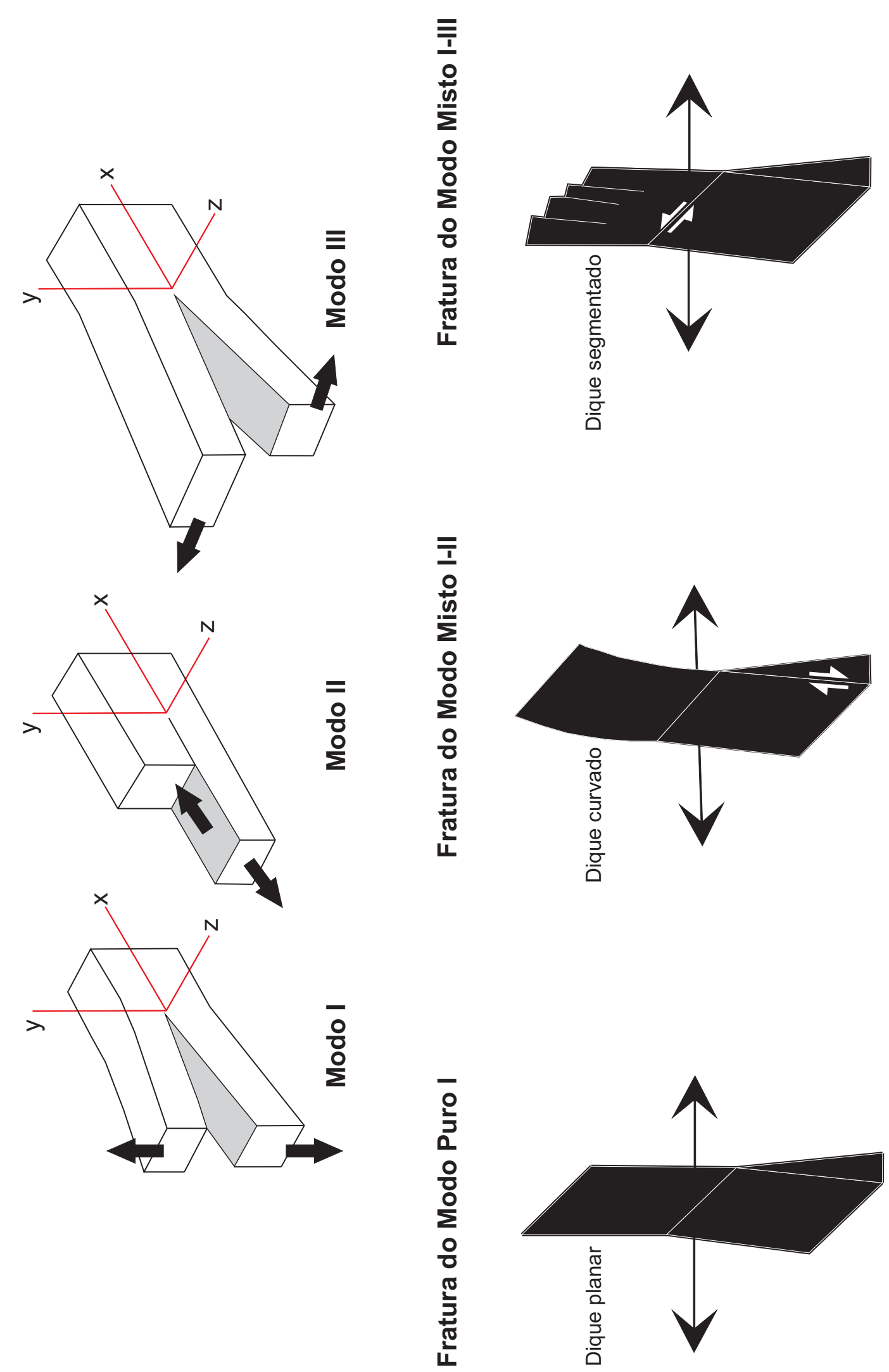
Marrett \& Peacock (1999) apontam que a terminologia utilizada para descrever o modo de ruptura de fraturas diz respeito apenas ao modo de propagação da fratura, sem relação com a geometria final da mesma. Uma vez que ensaios de mecânica de rochas demonstraram que tanto fraturas dos modos II e III, se propagam através da coalescência de micro fraturas do Modo I (Scholz 1990).

No estudo das relações entre preenchimento, fraturamento e propagação de diques, as condições de esforços responsáveis pelos diferentes modos de ruptura são interpretadas a partir de feições rúpteis localizadas nos contatos entre o dique e a rocha encaixante. Kattenhorn \& Watkeys (1995) denominam essas feições de Blunt-ended dyke segments, ou segmentos de diques com terminações abruptas, traduzidos geralmente como feições de borda de diques, descritas como pontes, chifres, tocos e degraus (vide Rickwood 1990, Figura 03).

Estas feições representam evidências físicas da relação entre o dique e a rocha encaixante e foram interpretadas de diferentes maneiras por diferentes autores: 1) colapso e rotação em torno do plano de propagação da fratura a partir da combinação dos modos de ruptura I -II e/ou I-III, formando uma fratura híbrida (Pollard et al. 1982); 2) acoplamento de segmentos sobrepostos de fraturas, diferenciando trajetórias de propagação retilíneas e curvas envolvendo a rotação e catáclase da rocha encaixante (Nicholson \& Pollard 1985); 3) transferência do processo de dilatação ao longo de fraturas pré-existentes (Baer \& Beyth 1990); 4) erosão magmática (Platten \& Watterson 1987); deformação dúctil causada por intrusão forçada (Noble 1952); dilatação ao longo de fraturas híbridas e/ou de cisalhamento, capazes de conectar segmentos do dique durante sua propagação, gerando cisalhamento da rocha encaixante paralelo à direção do dique (Kattenhorn \& Watkeys 1995).

A relação entre a geometria dos diques e o campo de tensões regional pode ser diferente ao modelo proposto por Anderson (1951) se os diques considerados tiveram seu alojamento controlado por uma zona de deformação não-coaxial (Glazner et al. 1999, Corrêa-Gomes et al. 2001). Nessas condições, fraturas de tração (Modo I) formadas no interior de uma zona de cisalhamento são geradas inicialmente perpendiculares à direção de mínimo esforço $\left(\sigma_{3}\right)$. No entanto, a existência de processos de deformação não-coaxial pode causar a rotação e acomodação dessas estruturas, conforme demonstrado por Ramsay (1980). Glazner et al. (1988) propõem a mesma 

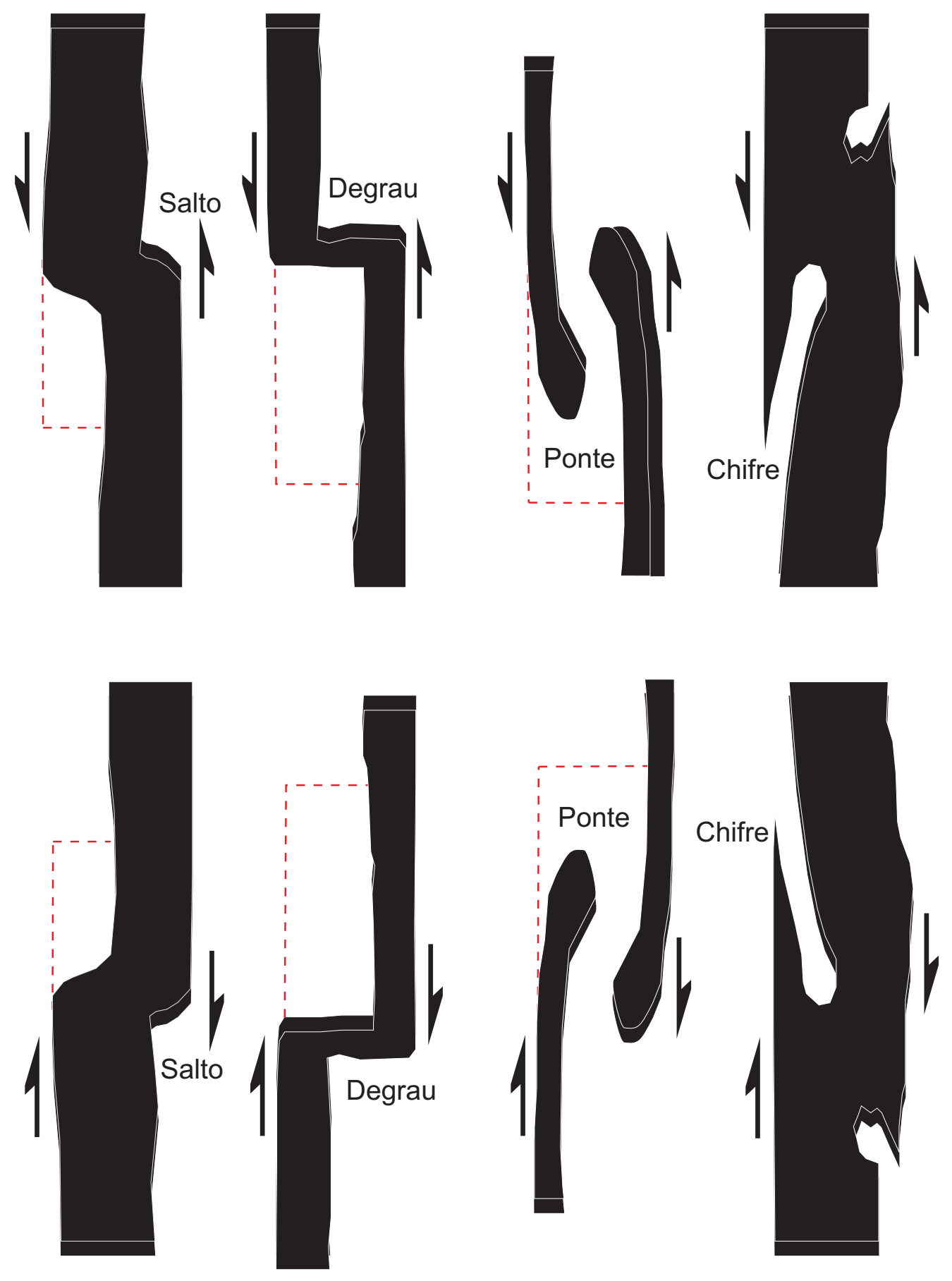

Figura o3 - Interpretação cinemática para feições de borda em segmentos de diques com terminações abruptas. Modificado de Rickwood (1990). 
relação para diques sin-cinemáticos com dilatação oblíqua em zonas de deformação não-coaxial.

Estruturas organizadas em arranjos escalonados ocorrem em diferentes escalas, desde centímetros até quilômetros em diferentes ambientes geológicos e podem ser preenchidas durante ou após sua formação por fluidos de diferentes naturezas desde hidrotermais até magmáticos e, geralmente, estão relacionados a regimes de esforços transcorrentes (Lajtai 1969, Ramsay 1980, Tchalenko 1992). Nesse caso, o esforço principal mínimo $(\sigma 3)$ orienta-se perpendicularmente a direção da fratura. Além disso, o arranjo geométrico das fraturas, principalmente quando escalonado, é utilizado para inferir o estado e as características da deformação (Ramsay \& Huber 1987) ou o regime de esforços na crosta durante o fraturamento (Pollard et al. 1983, Rickard \& Rixon 1983).

Berger (1971) sugere que em casos onde diques apresentam foliação mineral interna oblíqua às suas paredes, estas podem ser utilizadas como indicadores de movimentação lateral antes da consolidação completa da intrusão. Nesses casos podem ser observadas foliações oblíquas em lazy-S ou lazy-Z indicando movimentações destral e sinistral, respectivamente.

Bussel (1989) observa que feições de deslocamento semelhantes a pontes, chifres e degraus podem se formar a partir de deformações plásticas do magma e da rocha encaixante, produzindo feições do tipo pinch-and-swell e boudins, ou mesmo a partir de falhas nos estágios finais de consolidação do magma no interior de uma fratura e não apresentarem nenhuma relação com mecanismos de distensão oblíqua.

Seguindo a proposição de Delaney et al. (1986), Hoek (1991) argumenta que em termos geométricos um dique pode ser pensado a partir da combinação de um sistema de fraturas e de um campo de estiramento (dilation) que ocorre paralelamente à direção do esforço principal mínimo $(\sigma 3)$. $O$ autor propõe um sistema de classificação geométrica para diques, considerando estes como fraturas preenchidas reativadas e/ou neoformadas, distinguindo quatro geometrias principais: irregular, entrelaçado (braided), escalonado e zigzag. De acordo com o modelo, os três primeiros tipos seriam produtos do estiramento normal às paredes da fratura, enquanto o tipo zigzag seria produto do estiramento oblíquo aos segmentos de diques e normal ao "envelope" de propagação do dique (plano de propagação). 
Este tema, se dique aproveita uma fratura pré-existente ou gera uma nova, já tinha sido levantado por Holmes (1965). O autor propôs classificar os diques em dois tipos de intrusões: dilatantes (Dilation intrusions) e não dilatantes (Non dilation intrusions). O primeiro tipo representa diques associados a distensão e estiramento crustal e geralmente ocupam estruturas pré-existentes. O segundo tipo, por sua vez, representa diques que propagam sua própria fratura. $\mathrm{O}$ autor esclarece que geralmente este tipo de intrusão se encaixa em planos de falha e somente por este motivo pode ser reconhecida. Segundo Holmes (1965) intrusões não dilatantes são raras e de difícil reconhecimento, uma vez que para sua identificação segura deve-se obrigatoriamente ser observado o deslocamento de marcadores pré-existentes nas rochas encaixantes, o que nem sempre é possível.

Apesar do grande número de trabalhos utilizando diques como indicadores tectônicos, a compreensão da dinâmica e cinemática dos mecanismos envolvidos no alojamento desses corpos na crosta permanece um assunto relativamente mal entendido pela comunidade geológica. Segundo Zoback (1992), quanto mais raso o nível crustal de alojamento de um dique, maior será a tendência de que o controle da colocação seja exercido por descontinuidades pré-existentes. Assim, para validar a relação entre a orientação de diques e o campo de esforços atuantes durante o momento de sua colocação na crosta é conveniente a caracterização das descontinuidades existentes na rocha encaixante, para verificar possíveis relações na colocação dos corpos e o contexto estrutural envolvido.

$\mathrm{Na}$ presente dissertação, diques serão considerados como produtos da propagação de fraturas por mecanismos de fraturamento hidráulico, devido à pressão de fluido do magma. Nestas condições, enxames de diques podem preencher fraturas préexistentes e/ou gerarem sua própria fratura, dependendo do ângulo formado entre a fratura, ou um plano de fraqueza da rocha encaixante, e o esforço principal mínimo $(\sigma 3)$. Nestas situações, dois tipos de fraturas podem se formar: fraturas distensionais trativas e fraturas híbridas, envolvendo tração e cisalhamento (Figura 04). Neste caso, a orientação de diques, principalmente quando estes ocorrem na forma de enxames lineares, pode ser utilizada como indicador da orientação do esforço principal mínimo $(\sigma 3)$. No que diz respeito, a feições de borda de diques ou segmentos de diques com terminações abruptas, estas podem ser utilizadas como indicadores de nível crustal, uma vez que são formadas exclusivamente em estado rúptil. O uso dessas feições como 


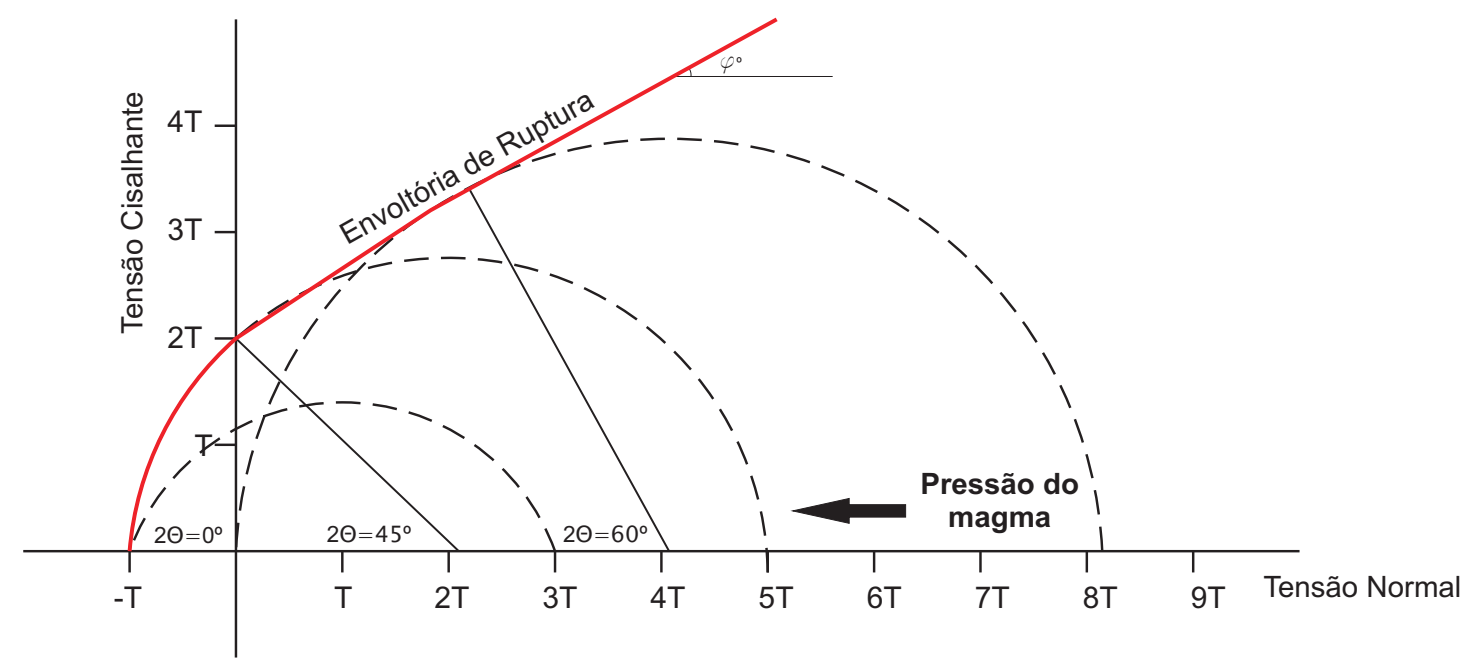

Figura o4 - Representação mecânica no Diagrama de Mohr das condições de ruptura e do efeito do magma na resistência das rochas. Note que a pressão de fluido diminui a resistência de ruptura da rocha encaixante. 
indicadores cinemáticos em diques nem sempre é seguro, uma vez que em um mesmo dique podem ser observados indicadores com deslocamentos opostos, além do fato destas feições admitirem diferentes explicações. No que diz respeito ao significado mecânico da presença de enxames de diques na crosta, estes podem ser utilizados como indicadores da direção do estiramento crustal sendo esta geralmente paralela à direção do esforço principal mínimo $(\sigma 3)$.

\section{2 - Diques como indicadores do regime tectônico}

Seguindo a proposição de que diques se alojam na crosta perpendicularmente à direção do eixo de menor esforço, $\sigma 3$ ou $\mathbf{S h}_{\min }$, alguns trabalhos demonstram a potencialidade do uso diques como paleoindicadores do campo de tensões em contextos tectônicos ativos tanto de abertura (e.g. McHone 1988, Faure et al. 1996, Jourdan et al. 2006) quanto de fechamento de oceanos, particularmente em regiões afetadas por falhas transformes (e.g. Féraud \& Campredon 1983, Féraud et al. 1987, Glazner et al. 1999).

Diques como paleoindicadores do campo de tensões em contextos de abertura do Oceano Atlântico são estudados em várias regiões de suas margens. Na Província Magmática do Atlântico Central, especificamente na costa leste da América do Norte, McHone (1988) conclui que os enxames de diques presentes nesta região marcam a vigência de um evento de deformação distensivo, evidenciado pela presença de enxames de diques de direção predominante NE-SW, sendo a direção NW-SE interpretada como a direção do esforço principal mínimo $(\sigma 3)$ paralela a direção de estiramento.

No extremo norte da costa leste da América do Norte, Faure et al. (1996) concluem que os enxames de diques básicos da Província Magmática de New EnglandQuebec marcam um evento de deformação distensional de direção NE-SW, correspondendo a direção de $\sigma 3$ enquanto a direção NW-SE contempla o esforço principal intermediário $\sigma 2$ ou $\mathrm{Sh}_{\max }$. Segundo os autores, estas direções são compatíveis com falhas normais contemporâneas aos diques.

Geoffroy et al. (1993) demonstram que em locais sob vigência de regime de esforços trativos, como na ilha de Skye na Escócia, onde afloram rochas vulcânicas extrusivas e intrusivas vinculadas ao magmatismo toleítico do Mar do Norte, o campo 
de tensões regional pode ser modificado pela intrusão e dinâmica de corpos plutônicos por um campo de tensões compatíveis com regimes de esforços transcorrentes. Nesse contexto, os autores descrevem diques de basaltos alcalinos e toleíticos com direções compatíveis com o alojamento sob regime de esforços transcorrentes.

Os exemplos citados acima demonstram uma relação empírica entre o campo de esforços regional, a dinâmica de falhas e o alojamento de diques. Nesses casos, foi demonstrado que geralmente a direção de um dique é controlada por um plano que contém os esforços principais máximo e intermediário $(\sigma 1$ e $\sigma 2)$ e ortogonal ao esforço principal mínimo $(\sigma 3)$. Assim, podemos concluir que em diques representam bons indicadores do campo de tensões regional e do estilo de deformação atuante na crosta durante a intrusão. Para a determinação do regime tectônico, o uso somente de diques é inconclusivo.

\section{3 - Fluxo magmático em diques}

Durante os últimos anos, a ideia de que o fluxo magmático em diques ocorre unicamente no plano vertical foi completamente abandonada. Apesar de trabalhos pioneiros realizados no início do século XX demonstrarem evidências de movimentações laterais de magma, o contrário perdurou como verdade até as últimas décadas do mesmo século (Rickwood 1990). A partir do trabalho de Smith (1987), muitos outros autores demonstraram que dependendo do nível de erosão observado em um dique, este pode revelar evidências de fluxo magmático vertical, horizontal ou até mesmo inclinado (e. g. Baer \& Reches 1987, Ernst 1990, Halls \& Bates 1990, Greenough \& Hodych 1990, Phillpots \& Asher 1994).

Em corpos tabulares de rochas ígneas, a interação entre a rocha encaixante e as bordas do corpo intrusivo representa o principal mecanismo gerador de feições indicadoras de fluxo magmático. Logicamente, o fluxo inicial é causado pelo pulso primário de injeção do magma que pode ocorrer com diferentes componentes de movimentação entre os sentidos horizontal e vertical, o sentido de movimento deste pulso é sempre de baixo para cima. Bussel (1989) observa que, de fato, movimentos verticais e laterais podem coexistir em um mesmo momento em diferentes partes de um mesmo corpo intrusivo. 
A interação entre o dique e a rocha encaixante é marcada por um enorme contraste reológico, estabelecido principalmente pelas diferenças de temperatura e viscosidade entre o magma e a rocha encaixante. Tais diferenças são observadas internamente ao dique, devido ao gradiente de temperatura estabelecido a partir das bordas em direção ao centro do corpo. O processo de cristalização mais rápido nas bordas, pelo contato com a encaixante mais rígida e fria, em relação ao centro do dique, gera uma série de descontinuidades reológicas paralelas às bordas do corpo, onde ocorrem processos de cisalhamento. As velocidades menores nas bordas e maiores no centro do corpo tendem a causar rotações nos minerais já cristalizados, fazendo os mesmos ocuparem posições de menor resistência ao fluxo. Por outro lado, com o aumento da taxa de solidificação a viscosidade do magma também aumenta, acentuando a dificuldade de movimentação dos indicadores cinemáticos (Corrêa-Gomes et al. 2001). Nesses casos, a diferença na taxa de cisalhamento entre as bordas e o centro do corpo magmático representa o principal mecanismo gerador de marcadores de fluxo.

Dessa maneira podemos observar diferentes modos de determinar a direção de fluxo magmático em diques. Os principais e mais confiáveis indicadores cinemáticos são representados por elongação de vesículas isorientadas, imbricação e elongação de fenocristais, estrias de fluxo, alinhamento de xenólitos, rincle marks, scour marks, fingers marks, dobras de arrasto e falhas sin-magmáticas (Baer \& Reches 1987, Rickwood 1990, Philpotts \& Asher 1994, Corrêa-Gomes 1996, Liss et al. 2002).

Outra maneira para determinar a direção do fluxo magmático em rochas ígneas intrusivas é através do uso da anisotropia de suscetibilidade magnética (ASM). Apesar da popularidade dessa ferramenta, as relações entre o fluxo magmático e a anisotropia de suscetibilidade magnética são ainda temas de debates entre os estudiosos do assunto (Hargraves et al. 1991). Em alguns casos, as comparações entre a direção de fluxo observada a partir de indicadores morfológicos, com direções de fluxo determinadas através do uso da ASM, mostram enormes discrepâncias. Philpotts \& Asher (1994) demonstram que em diques especialmente grandes $(>250 \mathrm{~km})$ como o dique de Higganum na Bacia de Hartford nos EUA, o fluxo de magma pode apresentar uma história relativamente complexa. Os autores descrevem a ocorrência de fluxo em pelo menos dois sentidos, uma direção aparentemente concordante com o sentido de alojamento e outra com sentido contrário. Em exemplos como esse, o uso da ASM 
como única fonte de informação para a determinação da direção e sentido de fluxo é particularmente inadequado.

Outra questão importante diz respeito ao modo de ocorrência de minerais magnéticos em rochas basálticas extrusivas e intrusivas. Nestas rochas a trama magnética é quase que exclusivamente dominada por óxidos de ferro e titânio, como a magnetita $\left(\mathrm{Fe}_{3} \mathrm{O}_{4}\right)$, a titanomagnetita $\left(\mathrm{Fe}_{2} \mathrm{TiO}_{4}\right)$ e ilmenita $\left(\mathrm{FeTiO}_{3}\right)$. Tais minerais normalmente se cristalizam tardiamente em relação aos silicatos preenchendo espaços intersticiais da trama. Este fato indica que os minerais magnéticos podem adquirir sua magnetização posteriormente à cristalização da trama de minerais silicáticos. De certa maneira, estas evidências podem explicar as discrepâncias observadas em determinações de fluxo magmático através de propriedades magnéticas (ASM) e indicadores morfológicos e trama mineral. 


\section{SIGNIFICADO GEODINÂMICO DE ENXAMES DE DIQUES}

O termo "enxame de diques" (dykes swarm) foi utilizado por Holmes (1944) para designar uma concentração de corpos tabulares de rochas ígneas intrudidas na crosta durante um mesmo evento magmático. No entanto, ferramentas como paleomagnetismo, petrologia, geologia estrutural e geocronologia mostraram em trabalhos posteriores que raramente a colocação destes corpos ocorre em um único evento e sim em sucessivos pulsos magmáticos que afetam a crosta durante um determinado intervalo de tempo. De acordo com Holmes (1965), diques máficos e ultramáficos representam uma expressão comum do processo de distensão da litosfera, tanto oceânica como continental, e constituem o principal mecanismo de transferência de magmas do manto para níveis superiores da crosta.

Segundo Dilek et al. (2000), em áreas oceânicas, intrusões na forma de diques desempenham importante papel no desenvolvimento e evolução do fundo marinho, sendo uma feição ímpar para o reconhecimento de antigas sucessões ofiolíticas na forma de camada de complexos de diques (sheeted dyke complexes). Em complexos vulcânicos oceânicos e/ou continentais, diques fazem parte, muitas vezes, do sistema alimentador estabelecido entre a câmara magmática e o edifício vulcânico (Halls \& Fahrig 1987). No interior da crosta oceânica atual, enxames de diques variam em idade desde o Triássico-Jurássico até o presente, onde intrusões se propagam lateralmente ao longo de zonas de fraturas conectando câmaras magmáticas profundas até a superfície, como na Islândia (Sigürdsson \& Sparks 1978). Ainda no interior da crosta oceânica, a advecção vertical e horizontal de massa e calor provida pelos diques possui potencial para induzir falhamentos próximos à dorsal através de modificações do campo de tensões locais e da estrutura axial e dinâmica da litosfera (Behn \& Ito 2008).

Em regiões continentais, a maioria dos enxames de diques se estende por centenas de quilômetros afetando enormes áreas Muitos desses enxames apresentam altas taxas de distensão crustal atestando enormes volumes de magma máficoultramáfico acrescido à crosta continental (McHone 1988). 
Os enxames de diques em regiões continentais, de uma maneira geral, apresentam ocorrência comum no Proterozoico e ampla distribuição no Fanerozoico, mais especificamente entre o Triássico e o Cretaceo, geralmente associados às grandes províncias magmáticas (Wilson 1989). A profusão de diques pré-cambrianos encontrados em áreas continentais, quando comparada com as ocorrências do Fanerozoico, principalmente as do Mesozoico, sugere que as rupturas continentais no Pré-cambriano eram provavelmente favorecidas pelo maior gradiente geotérmico e por anomalias nas correntes de convecção, além de possivelmente a existência de uma litosfera menos espessa e mais propensa a rupturas (Halls 1982).

Neste mesmo contexto, também são observados enxames de diques que avançam no interior do continente ao longo de zonas de fraturas interpretadas como ramificações abortadas de junções tríplices (Burke \& Dewey 1973). Como exemplos do Précambriano: Goiás-Crixás, 2.5 Ga (Brasil; Costa et al. 2006), Tandilia, 2.0-1.7 Ga (Argentina; Iacumin et al. 2002), Oeste Uruguai, 1.8-1.7 Ga (Uruguai; Bossi et al. 1993), Mackenzie-Sudbury dykes, 1.27 Ga (Canadá; Fahrig 1987), Keweenawan dykes 1.10 Ga (Canadá; Wallaace 1981), Salvador, 1.0 Ga (Brasil; Oliveira et al. 2000, D'Agrella-Filho et al. 2004), Greenland-Davis Strait 720 Ma (Canadá; Denyszyn et al. 2006) South Oklahoma 550 Ma (EUA; Keller et al. 1983); Rellfoot, St. Lawrence e Lake Melville 570-540 Ma (EUA; Hoffman 1989), Itabaiana 530-520 Ma (nordeste do Brasil, Trindade et al. 2006) e do Mesozoico: Atlântico Central 200 Ma (costa sudeste dos EUA; May 1971, McHone 1988, Beutel 2005, 2009), Karoo 185-177 Ma (África do Sul; Jourdan et al. 2006), Rio Ceará-Mirim 140-120 Ma (nordeste do Brasil; Misuzaki et al. 2002), Paraná-Etendeka, 137-115 Ma (Brasil-Namíbia; Coutinho 2005, Riccomini et al. 2005), Cuaró 132 Ma (Uruguai; Masquelin et al. 2009), Whitsunday, na costa leste da Austrália, 132-95 Ma (Bryan et al. 2000), Taupo na Nova Zelândia 132-90 Ma (Eawart et al. 1992).

Fahrig (1987) propõe um modelo baseado na evolução de uma margem passiva, onde enxames de diques se formariam em pelo menos três segmentos distensionais, sendo que um deles não evoluiria para uma margem passiva, representando um braço abortado do processo de ruptura continental (Figura 05). Para Fahrig (1987), o ciclo completo de evolução de um enxame de diques estaria intimamente associado ao próprio Ciclo de Wilson, ocorrendo em três estágios principais: 


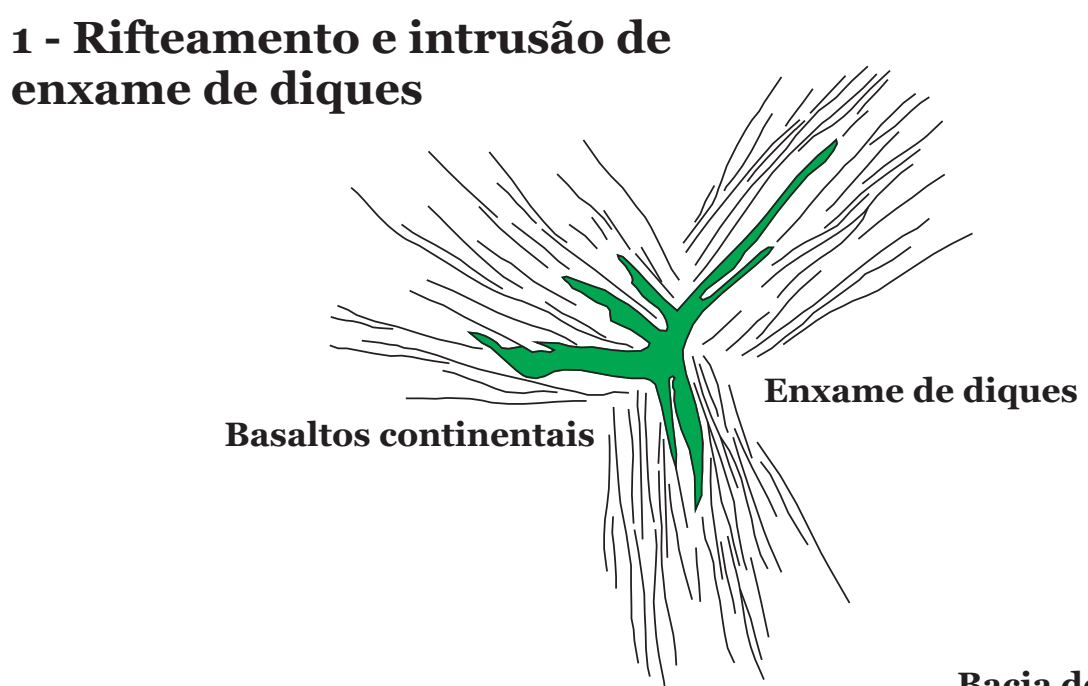

\section{2 - Distensão crustal e espalhamento oceânico}
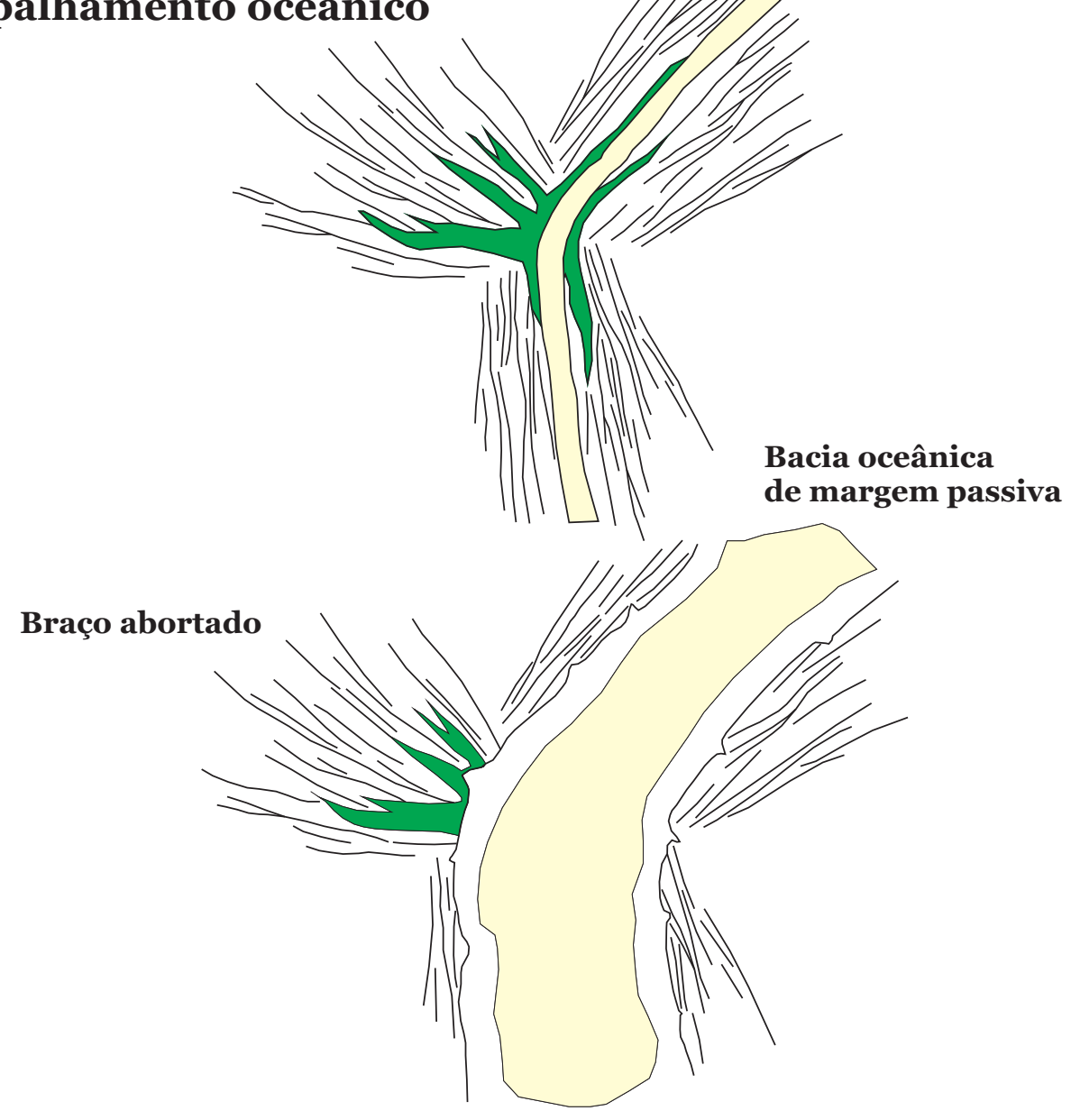

Figura 05 - Estágios evolutivos de enxames de diques continentais, simplificado de Fahrig (1987). 
i) Magmatismo e intrusão de enxames de diques na crosta seguido do processo de rifteamento;

ii) Evolução do magmatismo e formação de crosta oceânica;

iii) Evolução do Ciclo de Wilson com deformação dos enxames de diques durante o fechamento oceânico.

Buck (2006) chamam atenção para o fato de que a intrusão de diques e enxames de diques quase sempre está associada a eventos de ruptura continental. Segundo os autores, a intrusão de diques representa uma forma de acreção crustal em ambientes tectônicos distensionais como limites divergentes de placas, centros de expansão de crosta oceânica e rifts continentais, onde o magmatismo intrusivo acomoda grande parte da distensão crustal, proporcionando a ruptura da litosfera através de um processo denominado pelos autores como distensão magmática. Os autores demonstram que a ruptura da crosta continental é facilitada, em termos de magnitude de esforço e tensão de escoamento (yield stress), quando o magmatismo é envolvido no processo (Figura 06).

De acordo com os conceitos desenvolvidos a partir de Holmes (1944), atualmente, os grandes enxames de diques máficos, juntamente com as grandes províncias de rochas ígneas são responsáveis diretos pela criação em um curto intervalo de tempo de grandes volumes de crosta, especialmente em bacias oceânicas e em contextos tectônicos divergentes. Os principais litotipos presentes neste ambiente tectônico correspondem a basaltos de bacias oceânicas (MORB), plateaus basálticos em regiões continentais, basaltos subaéreos de seaward-dipping reflectors, planaltos oceânicos, cordilheiras submarinas, grupos de montes submarinos e, ainda, rochas intrusivas composicionalmente equivalentes na forma de enxames de diques, soleiras e basaltos intrudidos na crosta inferior (underplating), e derrames riolíticos (White \& McKenzie 1989, Jackson et al. 2000, Sears et al. 2005, Torsvik et al. 2009, Aslanian et al. 2009).

Tais conjuntos litológicos representam associações petrotectônicas características de ambientes distensivos do tipo rift que efetivamente evoluíram para bacias sedimentares oceânicas de margens passivas vulcanogênicas (sensu Menzies et al. 2002) conjugadas a exemplo das bacias marginais da margem continental do Brasil e 


\section{A)}

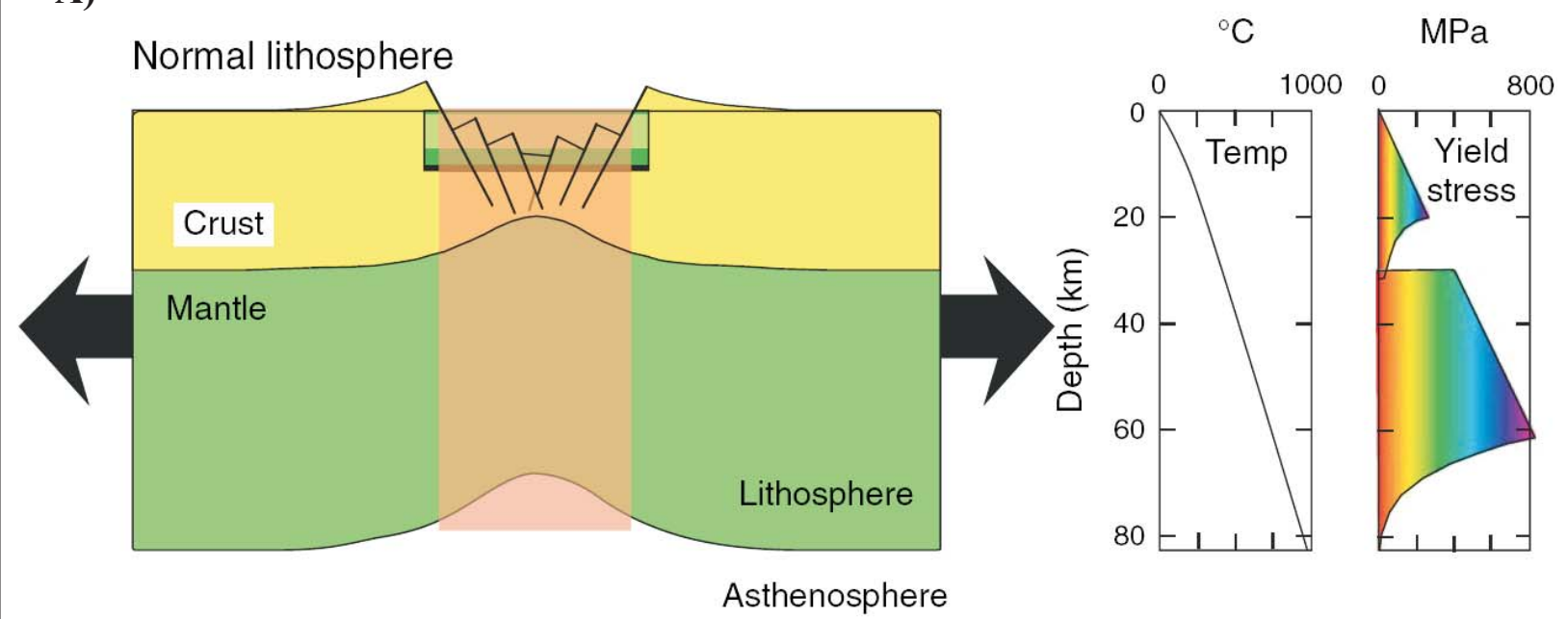

B) Magmatic extension
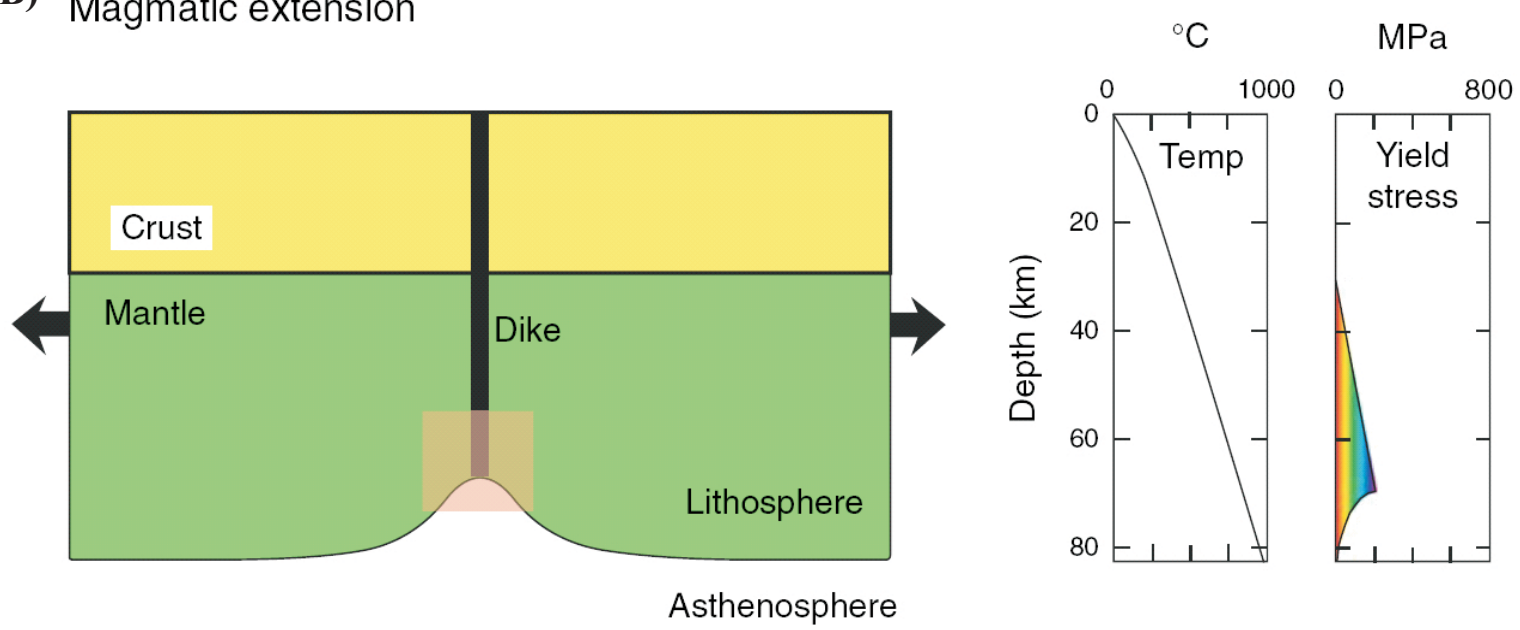

Figura o6 - Modelo esquemático demonstrando duas formas de distensão crustal. Note a enorme diferença de tensão de escoamento (yield stress) necessário para o processo sem magmatismo (A); e com envolvimento de magmatismo na forma de intrusão de enxame de diques (B), segundo Buck (2006). 
suas contrapartes no continente africano (e.g. Marton et al. 2000, Jackson et al. 2000, Bueno 2004, Torsvik et al. 2009, Aslanian et al. 2009).

\section{1 - A importância de Sir Arthur Holmes (1890-1965) no tema de estudo}

A discussão sobre a relação entre enxames de diques e os fenômenos de ruptura continental é um tema relativamente recente, mas a ideia, não: o primeiro a relacionar de forma clara que a formação de enxames de diques máficos em regiões continentais representaria sinais de atividades tectono-magmáticas precursora da ruptura dos continentes foi Sir Arthur Holmes na segunda edição de seu clássico livro Principles of Physical Geology em 1965.

Arthur Holmes (1890-1965) foi um dos geólogos mais influentes do século XX. Trabalhou como professor assistente no Imperial College entre 1912 e 1920, posteriormente como geólogo chefe de uma companhia de exploração de petróleo em Myanmar. Após isso, a partir de 1924 lecionou geologia na Universidade de Durham onde fez quase toda a sua carreira como professor e cientista. Em 1943 foi indicado para o posto de professor titular (Regis Professor) na Universidade de Edinburgh, onde deu aulas de geologia geral e mineralogia até sua aposentadoria em 1956.

Uma excelente síntese sobre a obra de Arthur Holmes está contida no livro "The Rejection of Continental Drift' (Oreskes 1999). De acordo com esta obra, em uma série de artigos publicados entre 1925 e 1933, Holmes apresentou um modelo que poderia explicar o mecanismo motor da deriva continental, conforme a proposição inicial de Alfred Wegener. No principal trabalho, publicado no número XVIII do Transactions of the Geological Society of Glasgow em 1929, Holmes propôs a existência de células de convecção no manto que dissipariam o calor gerado pelo decaimento isotópico de elementos radioativos. A ideia de Holmes integrava conceitos petrológicos e tectônicos, explicando uma série de fenômenos, como a origem das bacias oceânicas e a formação de rochas metamórficas de alta pressão como os eclogitos (Figura 07). De acordo com Holmes, bacias oceânicas se formariam em locais que a litosfera sofreria esforços trativos onde ocorreria extrusão de magmas basálticos na superfície. Deve ser levado em atenção que Holmes foi o primeiro a sugerir os mecanismos que viriam ser as bases para a visão moderna da dinâmica da Terra e de suas placas tectônicas. 


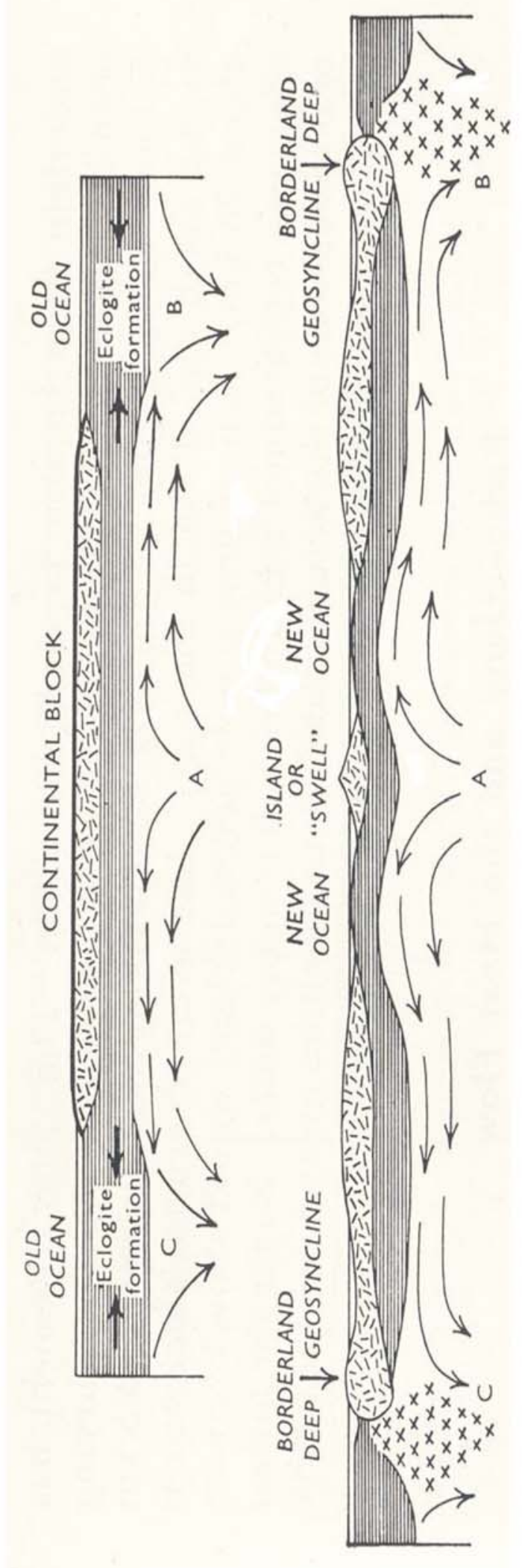

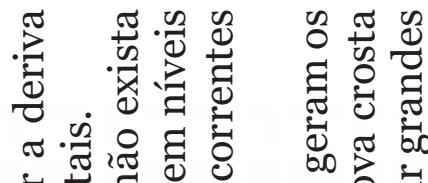

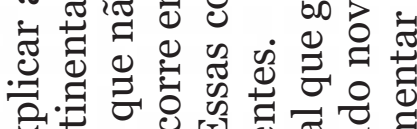

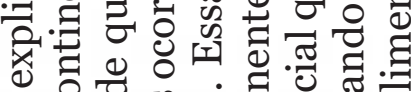

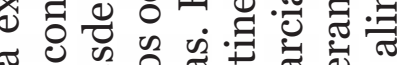
สँ คิ

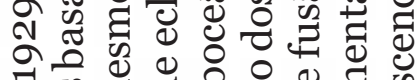
घ दี च ० ข

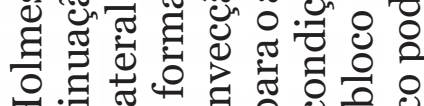

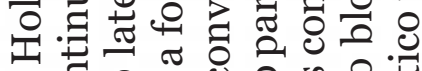

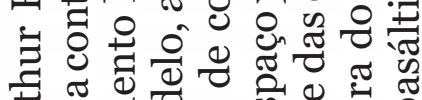

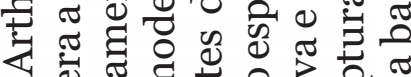
๘ี

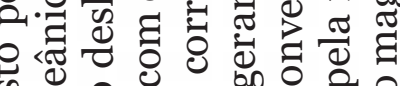
获

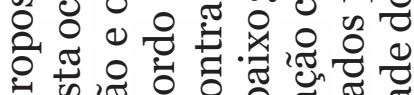
పు

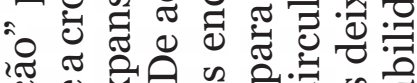

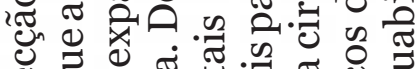

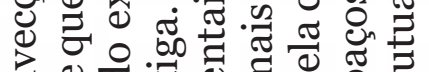

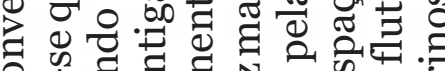
ช సี ช ๑ 仓

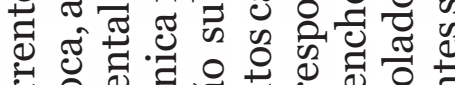
ปั

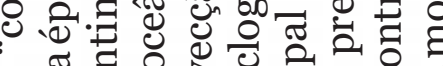

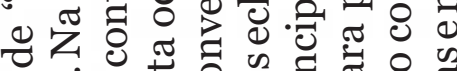

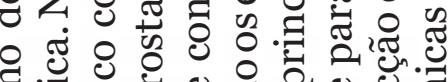

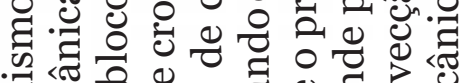

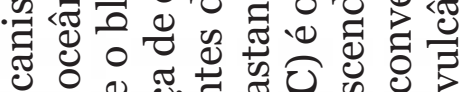

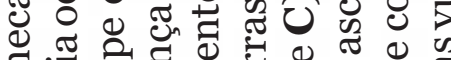

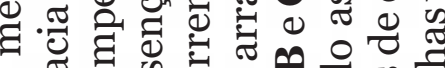

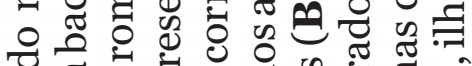

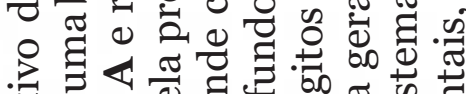
.

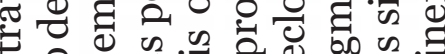

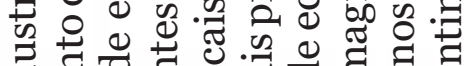

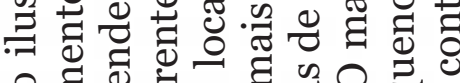

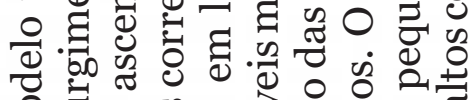

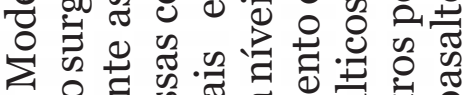

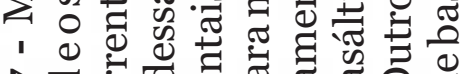

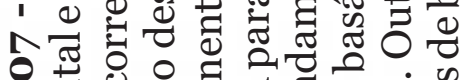

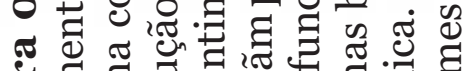

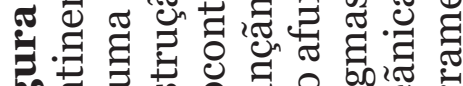

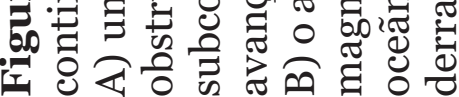


Apesar da originalidade e importância, as ideias de Holmes foram deixadas de lado principalmente pela escola geológica norte-americana, que considerava de forma pejorativa e preconceituosa a ciência geológica baseada em métodos indutivos, como a observação e o raciocínio lógico, valorizando mais métodos laboratoriais e analíticos do que "evidências de campo" (Oreskes 1999). Este fato prevalece até os dias de hoje, onde a influência da escola geológica norte-americana praticamente domina as ciências da Terra.

Em 2005, 76 anos depois da publicação do clássico artigo no Transactions of the Geological Society of Glasgow, a Geological Society of America publicou um volume especial: Plates, Plumes, and Paradigms (Foulger et al. 2005), onde os organizadores do livro reconhecem Arthur Holmes como o pai da moderna Teoria da Tectônica de Placas.

\section{2 - Rifts, grandes províncias ígneas, hot spots e plumas do manto}

Os enxames de diques, principalmente do Mesozoico, apresentam como característica comum o fato de serem abundantes paralelos e, mais raramente, transversais às margens continentais, em regiões localizadas em margens passivas que sofreram processos de rifteamento, geralmente vinculados a grandes províncias de rochas ígneas (LIPs - Large Igneous Province).

Províncias de basaltos continentais representam a principal forma de ocorrência de imensos volumes de rochas ígneas máficas intrusivas e principalmente extrusivas, geralmente consideradas como produtos de erupções em um curto intervalo de tempo (Coffin \& Eldholm 1992, 1993, 1994). Estes autores designam tais regiões como LIPs, fazendo uma distinção entre grandes províncias de rochas ígneas oceânicas e continentais. As LIPs oceânicas são constituídas por rochas ígneas intrusivas e extrusivas máficas formadoras de platôs oceânicos, basaltos de fundo oceânico, margens passivas vulcanogênicas, províncias de Seaward-dipping reflectors, cadeias e montes submarinos.

As províncias de rochas ígneas formadas por basaltos continentais representam extensos platôs vulcânicos, normalmente vinculados a ambientes tectônicos distensivos materializados pela associação comum com enxames de diques máficos. Olsen \& 
Morgan (1995) chamam atenção para o fato das LIPs nem sempre serem incluídas como expressões dos processos de rifteamento e abertura oceânica. Afirmam que tais províncias representam produtos dos processos de distensão litosférica geneticamente vinculadas a sistemas de rifts que evoluíram efetivamente para bacias oceânicas a partir da instalação de centros de espalhamento do assoalho oceânico (dorsais mesooceânicas), conforme o modelo de Hess (1960) e Dietz (1961). Estas regiões, onde ocorre magmatismo plutônico e vulcânico na forma de grandes províncias basálticas associadas a bacias sedimentares oceânicas de margem passiva, são denominadas de margens continentais vulcanogênicas (Menzies et al. 2002).

Sheth (2007) apresenta uma revisão a respeito dos conceitos e classificação das Large Igneous Province e sugere o uso de termos mais rigorosos em sua definição. Assim, o autor propõe o termo Large Basaltic Provinces - LBPs para as LIPs descritas acima. Apesar desta classificação ainda ser muito debatida (e.g. Bryan \& Ernst 2007), optou-se pelo uso das proposições sugeridas por Sheth (2007) pela clareza de seus critérios e argumentos.

Existem duas correntes teóricas para explicar a origem dos enxames de diques máficos e as grandes províncias basálticas. Basicamente, a corrente mais difundida e aplicada está relacionada aos modelos de plumas do manto, onde as grandes províncias de rochas ígneas, em especial as províncias basálticas (LBPs), são causadas por grandes anomalias térmicas formadas na interface manto-núcleo, de modo que a gênese de magmas basálticos estaria vinculada a processos de fusão parcial do manto e ascensão da astenosfera sem relação com mecanismos de distensão e afinamento litosférico (e. $g$. Richards et al. 1989, Hooper 1990, Griffiths \& Campbell 1991).

De uma maneira geral, as plumas do manto são definidas como grandes anomalias térmicas originadas na interface manto-núcleo em profundidades de aproximadamente $2900 \mathrm{~km}$ - camada D', coincidente com a Descontinuidade de Gutenberg (Stüwe 2007). Nesta profundidade do interior da Terra, uma importante mudança na velocidade de propagação de ondas $\mathrm{P}$ surge devido à alteração de estado entre o manto inferior sólido e o núcleo externo líquido. Esta camada representa um importante limite reológico devido à suas características térmicas e químicas (Figura 08). 

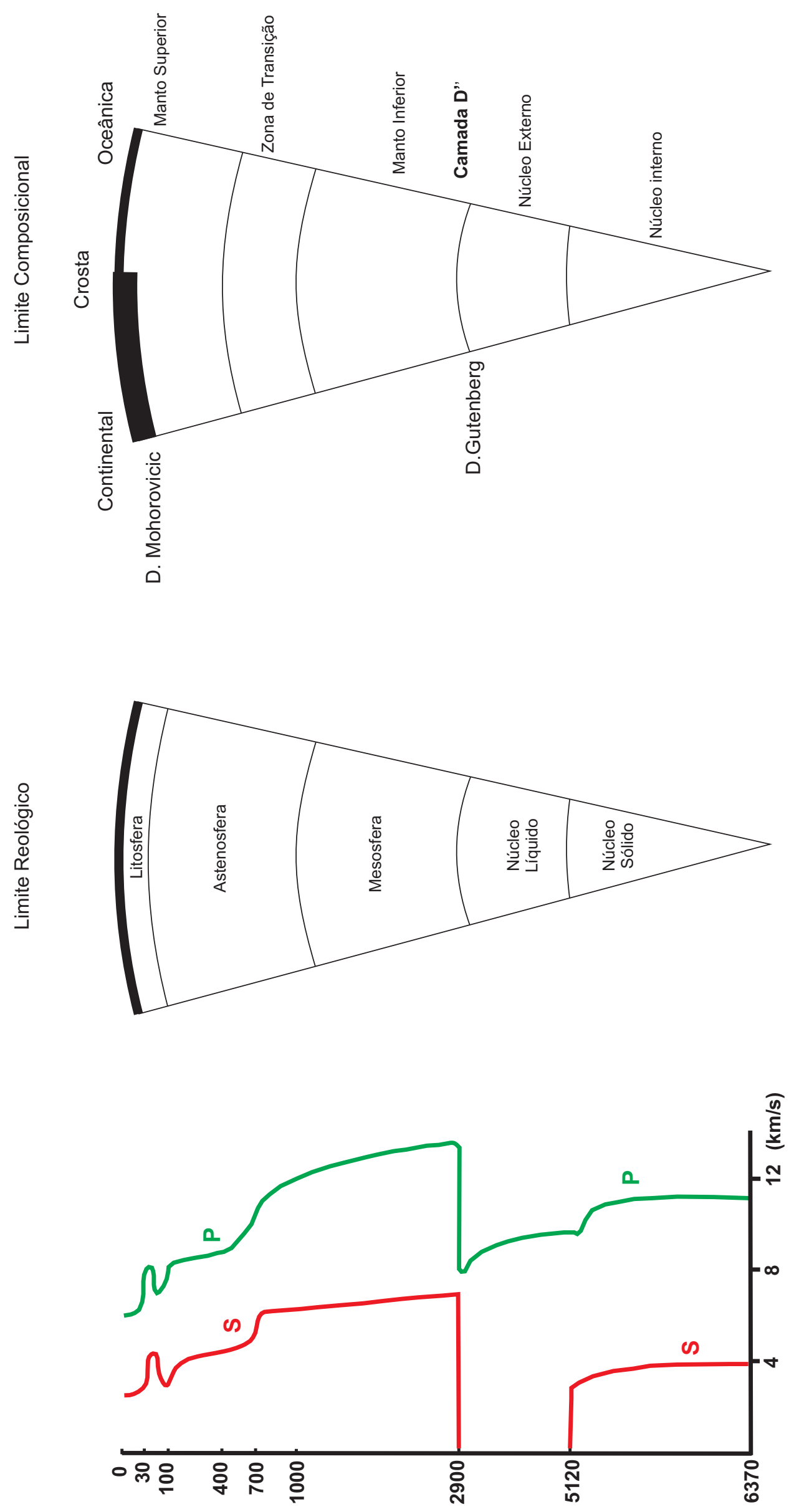
O modelo de plumas do manto advoga, através de processos essencialmente termais, que as diferenças composicionais, tanto geoquímicas como isotópicas, entre o magmatismo gerador de rochas vulcânicas intraplaca e interplacas são explicadas pela existência de dois grandes reservatórios mantélicos, de composição distinta, separados por uma descontinuidade sísmica situada em torno de $660 \mathrm{~km}$ de profundidade, responsável pela separação entre o manto superior e inferior (Anderson et al. 1992, Deuss et al. 2006). O reservatório mais profundo $(>660 \mathrm{~km})$ seria a fonte do magmatismo de ilhas oceânicas intraplaca (OIB), enquanto no mais raso $(<660 \mathrm{~km})$ seriam originados os basaltos MORB das dorsais meso-oceânicas. De acordo com Richards et al. (1989), experimentos de laboratório e modelos numéricos envolvendo dinâmica de fluídos em sistemas aquecidos corroboram essa interpretação. Hofmann (1997) e Schubert et al. (2001) apontam que as características da descontinuidade de $660 \mathrm{~km}$ determinam o estilo de convecção do manto, separando possivelmente uma porção onde todo o manto é envolvido no processo convectivo (manto superior), de outra onde a convecção ocorre de forma confinada (layered-mantle convection), representando o manto inferior. A verificação da existência desta descontinuidade $(660 \mathrm{~km})$ através de mudanças de fase ao longo da propagação de ondas sísmicas em grandes profundidades foi assinalada inicialmente por Ringwood (1975) e confirmada por outros autores (e.g. Ita \& Stixrude 1992, Deuss et al. 2006). Tais alterações foram atribuídas a mudanças composicionais do manto. Dois tipos de mudanças químicas foram sugeridos: $i$ ) mudança no teor de ferro (Anderson 1967, Sawamoto 1977, Stixrude et al 1992.); ii) mudança no teor de sílica (Anderson 1970, Stixrude et al 1992).

Para explicar a existência de vulcanismo intraplaca, como o arquipélago do Hawaii, e diferenças nas taxas de produção de magma em locais específicos de algumas dorsais oceânicas, Wilson (1963) apresentou um modelo onde, devido ao elevado gradiente de densidade do manto, as correntes de convecção ocorreriam na forma de "correntes de magma" (jet-stream type of convection). De acordo com o modelo, uma cadeia de ilhas vulcânicas seria formada através da passagem da crosta oceânica em movimento sobre a fonte de magma relacionada às tais correntes do tipo jet-stream. As fontes não precisariam ser efetivamente fixas, apenas movimentar-se com uma velocidade menor do que a corrente de magma. Este modelo ficou conhecido como hot spot, uma vez que seu principal aspecto esta relacionado à presença de anomalias 
térmicas, indicadas principalmente pelo volume de magma basáltico (Anderson \& Schramm 2005).

A partir dos trabalhos de Tuzo Wilson, Morgan (1971) introduziu o conceito de plumas termais profundas e fixas, responsáveis pela origem de cadeias lineares de ilhas oceânicas nas dorsais e montes submarinos intraplaca de natureza vulcânica, além de outras feições vulcânicas em dorsais não-sísmicas. O autor define hot spot como uma manifestação de fenômenos convectivos no manto inferior responsáveis pela força motriz das placas tectônicas. Tais manifestações foram denominadas pelo autor de "plumas de convecção".

É importante salientar que a definição de hot spot apresentada em Wilson (1963) não representa o mesmo conceito das "plumas de convecção" de Morgan (1971). De acordo com Anderson \& Shcramm (2005), o conceito de pluma surge nos trabalhos de Wilson no livro Physics and Geology (Jacobs 1974), onde Tuzo Wilson define pluma como:

"at level of 400 to $700 \mathrm{~km}$, the mantle becomes opaque, so that heat slowly accumulates untill, due to local irregularities, cylindrical plumes start to rise like diapirs in the upper part of the mantle. These plumes reach the surface, which they uplift, while their excess heat gives rise to volcanism. The lavas at these uplifts are partly generated from material rising from dephts of several hundred kilometers, which is thus chemically distinct from that generated to remain steady in the mantle for millions of years".

A diferença fundamental entre a proposição de Morgan (1971) e Wilson (1963) diz respeito a um aspecto crucial da Tectônica de Placas, o mecanismo motor. Morgan (1971) acredita que as plumas do manto são as responsáveis pela movimentação das placas tectônicas, enquanto Wilson (1963) acredita que o movimento das placas é causado pelas correntes de convecção conforme o modelo de Holmes (1929). Hoje sabemos que apesar da existência das correntes de convecção, o movimento das placas é atribuído principalmente aos processos de ridge push e slab pull (vide Kearey et al. 2009).

A hipótese de uma relação direta entre a disposição temporal e espacial das grandes províncias de rochas basálticas continentais e os eventos de ruptura continental foi proposta inicialmente por Morgan (1971). Baseados nesta proposição, Burke \& 
Dewey (1973) levantaram a hipótese de uma relação entre a ocorrência de processos de ruptura da crosta continental, com a presença de plumas do manto. De acordo com os autores, a ruptura continental se processaria especialmente em locais onde a crosta se encontra estacionada em relação a uma pluma mantélica. Nestes locais se formariam rupturas tipo rift facilitadas pelo desenvolvimento de junções tríplices do tipo rift-riftrift $(R-R-R)$, onde apenas dois segmentos evoluiriam até o desenvolvimento de uma bacia oceânica.

Şengör \& Burke (1978) discriminam dois tipos de processos de rupturas do tipo rift em relação ao tempo da interação magmatismo-rifteamento (Figura 09). No primeiro tipo, o magmatismo e o soerguimento dômico antecedem a principal fase de ruptura. Neste caso, o manto desempenharia papel ativo a partir de "plumas de convecção" (sensu Morgan 1971). Este tipo foi denominado de rift ativo. No segundo tipo, a movimentação horizontal das placas causa distensão e afinamento da litosfera proporcionando o rifteamento. Neste caso, o manto desempenha um papel passivo, sendo o magmatismo tardio em relação à fase principal de rifteamento. Esse modelo foi denominado de rift passivo. Mesmo discriminando estes tipos principais, os autores alertam que uma enorme variedade de condições locais pode resultar em alterações destas relações.

De acordo com Richards et al. (1989), as grandes províncias basálticas seriam resultado da presença de uma pluma do manto profunda e fixa, alojada de alguma maneira na base da crosta, sendo que o rifteamento seria posterior ao alojamento da pluma.

Courtillot et al. (1999) retomam a hipótese de Morgan (1971) e, a partir de dados radiométricos disponíveis, observam que nas grandes províncias basálticas o magmatismo extrusivo e/ou intrusivo precede ou tem início simultaneamente ao rifteamento, sugerindo uma relação de causa e efeito entre os dois fenômenos (Figura 10).

Carlson (1992) aponta que uma questão não resolvida e ainda polêmica sobre as grandes províncias basálticas, diz respeito à fonte do magmatismo. De modo geral, os modelos petrogenéticos existentes atribuem como fonte para esses magmas a astenosfera (e.g. McKenzie \& Bickle 1988, White \& McKenzie 1989, Arndt \& Christensen 1992) ou o manto litosférico (e.g. Gallagher \& Hawkesworth 1992). 


\section{A) Rift Passivo}

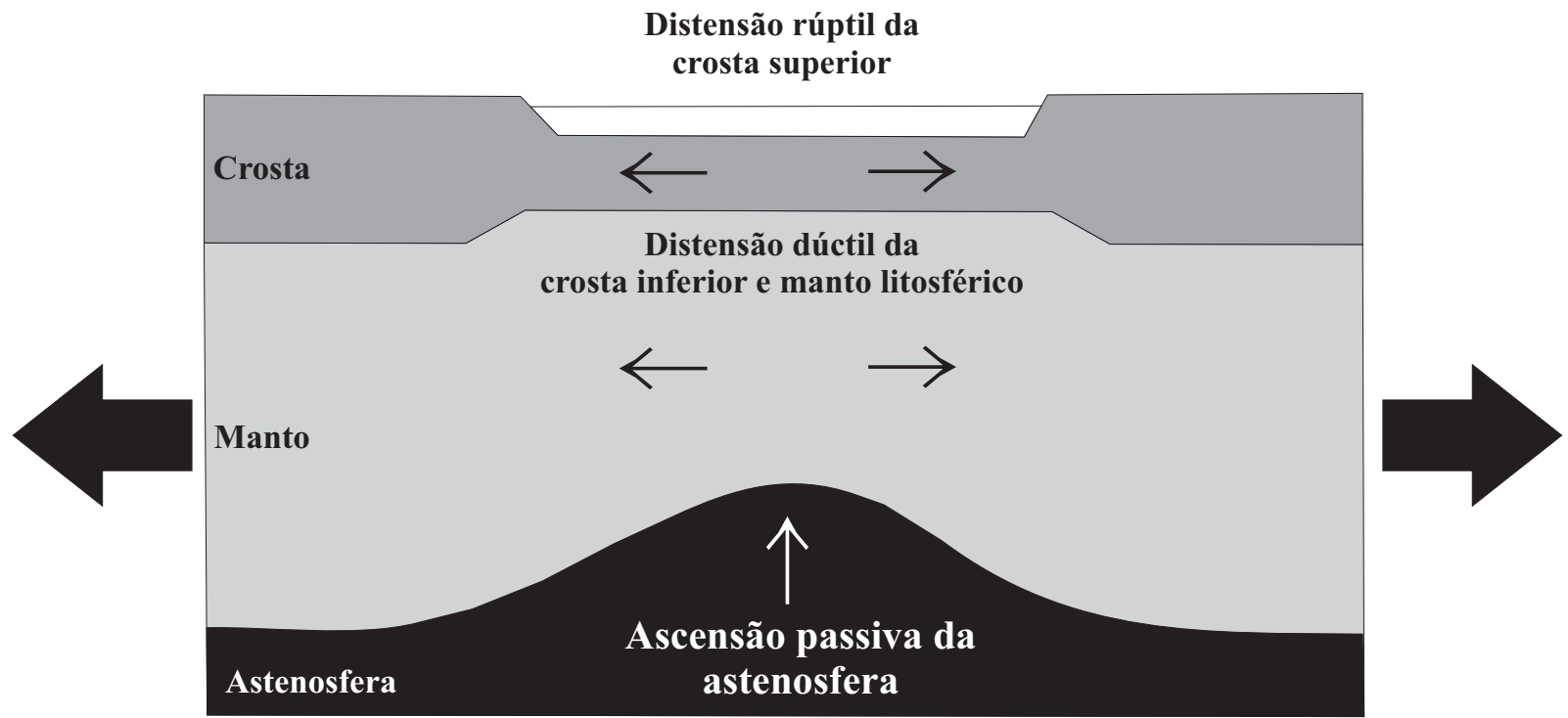

B) Rift Ativo

Soerguimento regional

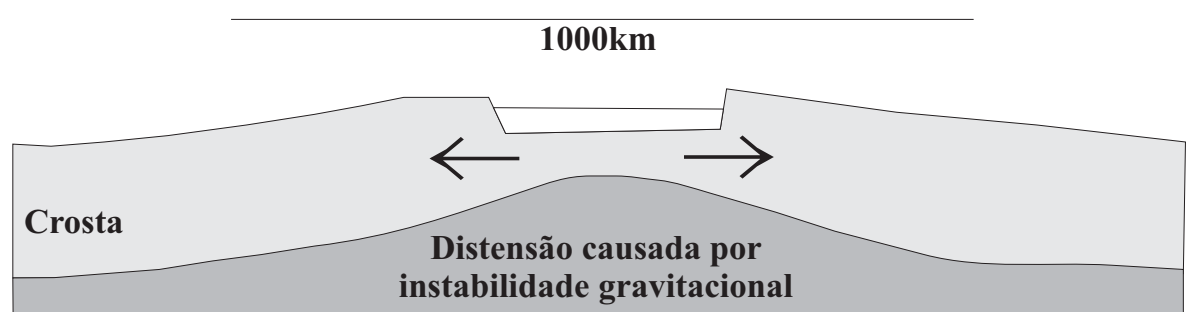
instabilidade gravitacional
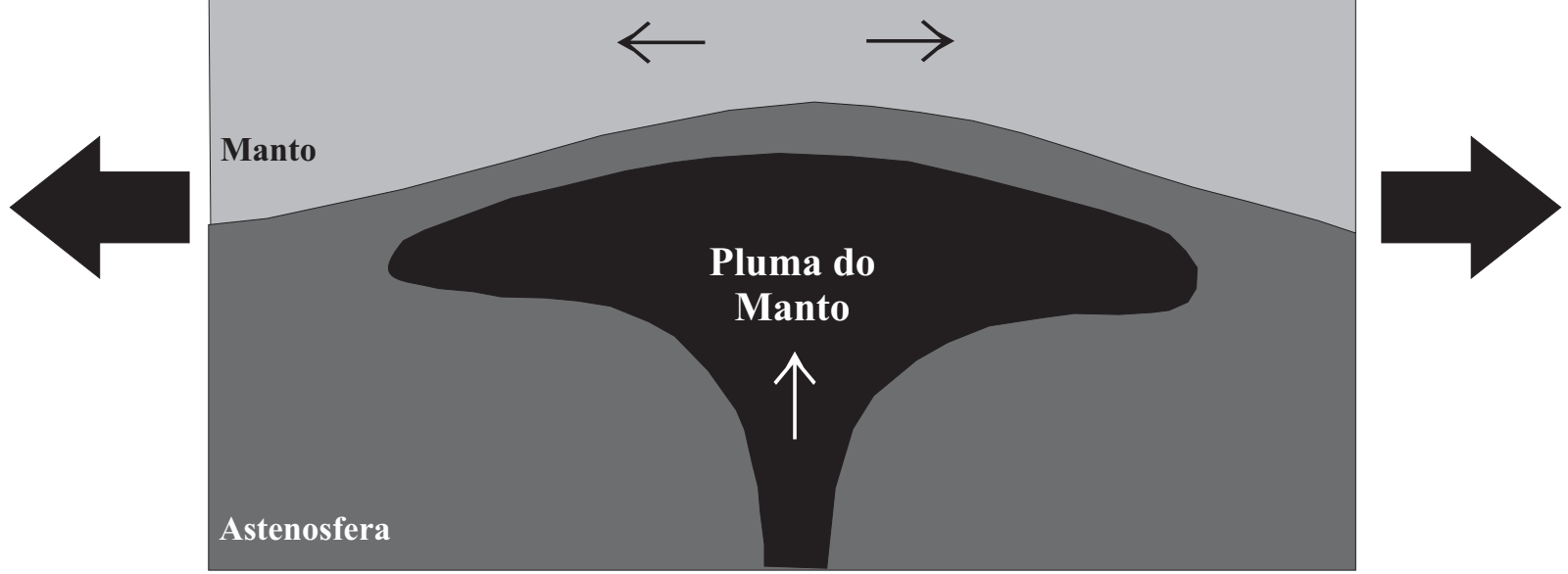

Figura 09 - Modelos teóricos de rifteamento. A) Rift passivo. B) Rift ativo. Segundo Şengor \& Burke (1978). 


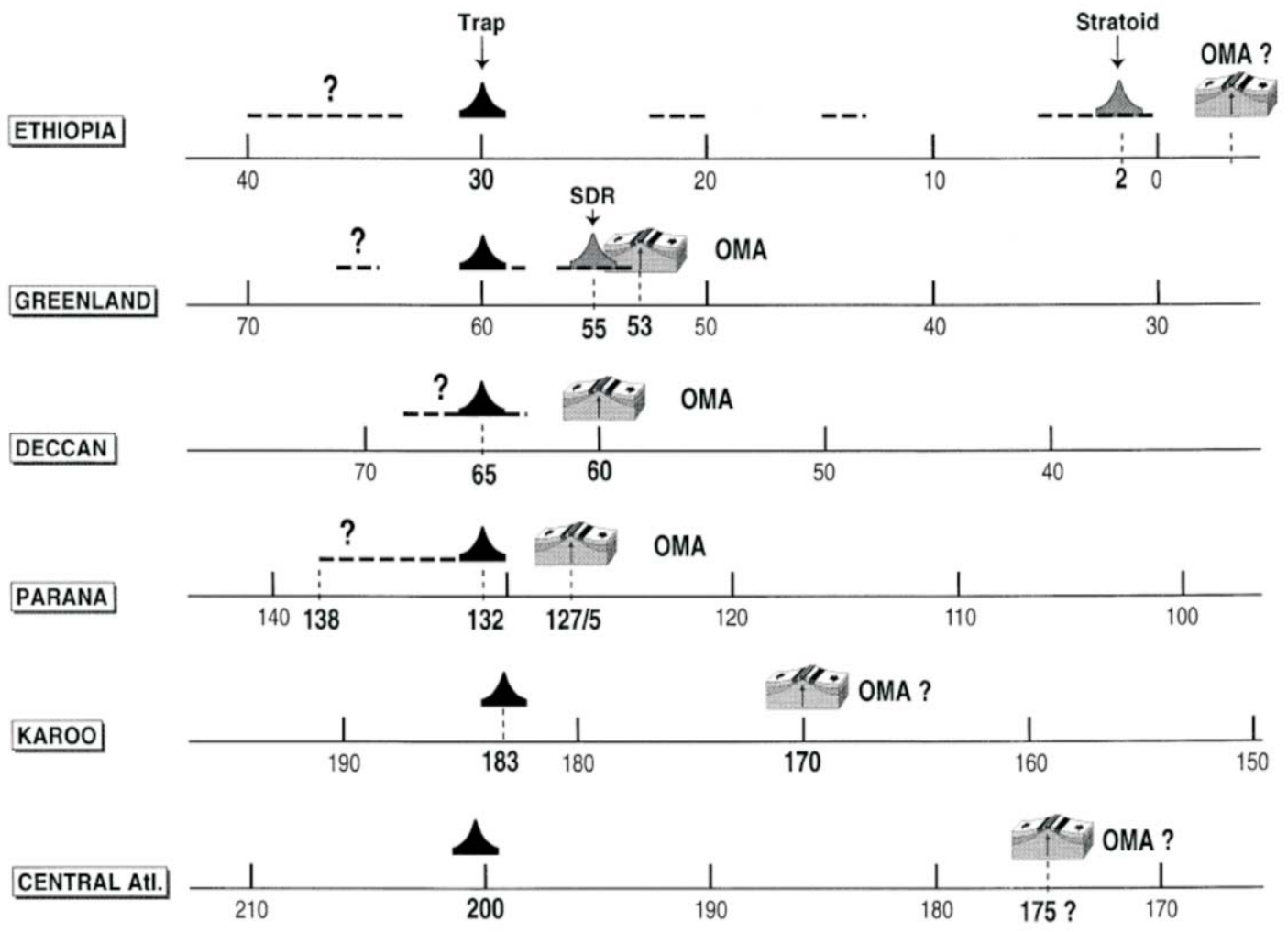

Figura 10 - Relações temporais entre o magmatismo e o surgimento das anomalias magnéticas oceânicas (OMA) em diferentes províncias basálticas, segundo Courtillot et al. (1999). 
Os modelos baseados em uma origem a partir da astenosfera são apoiados principalmente no fato de acreditar-se que a litosfera não possua condições térmicas suficientes para alcançar o elevado grau de fusão necessário para a geração desses magmas (1000-1200 $\left.{ }^{\circ} \mathrm{C}\right)$. De acordo com Carlson (1992), este seria o principal motivo da aceitação da hipótese das plumas do manto como responsáveis pela gênese das grandes províncias basálticas.

White \& McKenzie (1989) apresentam um extenso trabalho no qual discutem uma série de aspectos geológicos, geofísicos, petrológicos e geocronológicos e apresentam uma série de exemplos de rupturas continentais envolvendo magmatismo. Os autores sugerem que os processos de rifteamento formadores de bacias oceânicas são acompanhados por expressiva atividade ígnea. De acordo com o trabalho, o magmatismo nesses casos afeta tanto o rift propriamente dito como o continente adjacente. Segundo os autores, a produção de magma em bacias do tipo rift, que evoluem para bacias oceânicas de margem passiva e os derrames de basaltos continentais formadores das grandes províncias basálticas podem ser explicados por um modelo simples de rifteamento acima de uma anomalia térmica no manto subjacente. Segundo este modelo, as rochas ígneas são geradas através de fenômenos de fusão por descompressão adiabática do manto astenosférico à medida que o limite termal/reológico litosfera-astenosfera sobe passivamente abaixo da crosta continental estirada e afinada. Dessa forma, grandes volumes de magma seriam formados por processos de fusão parcial do manto astenosférico e de parte do manto litosférico, a partir de um incremento de temperatura da ordem de $100-200^{\circ} \mathrm{C}$ em regiões da crosta que tenham passado por distensão e afinamento litosférico (McKenzie \& Bickle 1988).

Os autores demonstram através de modelos quantitativos que este relativamente pequeno incremento de temperatura é suficiente para causar a geração de enormes quantidades de material fundido pela descompressão. O calor necessário para a fusão seria fornecido pela ascensão de uma pluma do manto, sendo esta também responsável pela formação de um extenso domeamento (bulge) na superfície da Terra, da ordem de 800 a $2000 \mathrm{~km}$ de amplitude e um soerguimento de 1 a $4 \mathrm{~km}$ de altitude (White \& McKenzie 1995).

Nesse contexto, diques e enxames de diques representariam elementos facilitadores da drenagem do líquido magmático gerado pelos fenômenos de fusão 
(McKenzie 1984). Cabe lembrar, que no trabalho de White \& McKenzie (1989), os autores utilizam o termo "plumas do manto" como sinônimo de hot spot baseando-se nos trabalhos de Wilson (1963) e Morgan (1971) que, como demonstrado anteriormente, não apresentam o mesmo significado.

No entanto, Gallagher \& Hawkesworth (1992) apresentam um modelo alternativo, onde as condições necessárias aos processos de fusão seriam facilitadas pela presença de água fato do manto litosférico apresentar certa abundância no conteúdo de água, o que seria comprovado pelas assinaturas geoquímicas litosféricas verificadas em diferentes províncias basálticas.

Hawkesworth \& Gallagher (1993) admitem que grandes eventos de fusão do manto superior requerem altas temperaturas. No entanto os autores argumentam que para que isso ocorra não é preciso a presença de plumas do manto, bastando fenômenos de distensão regional da litosfera.

A popularidade e difusão do modelo de plumas do manto transformaram tal hipótese em um paradigma para o entendimento das grandes províncias basálticas e dos processos de ruptura continental, conforme alertado por Thompson (1998). Tais conceitos foram desenvolvidos e difundidos principalmente por geofísicos que fomentaram a hipótese das plumas do manto, bastante utilizada como sustentação teórica para explicar a origem dos rifts intraplaca e do magmatismo intraplaca associado aos processos de ruptura continental (e. g. Richards et al. 1989, Hooper 1990, Hill 1991 e Griffiths \& Campbell 1991).

Courtillot et al. (2003) propõem 5 aspectos básicos para classificar uma atividade vulcânica como do tipo hot spot: 1) existência de cadeias vulcânicas lineares intraplaca com progressão gradual de idade; 2) existência de uma grande província basáltica associada com presença de rochas picríticas; 3) razões ${ }^{3} \mathrm{He} /{ }^{4} \mathrm{He}$ nas rochas vulcânicas, pelo menos 10 vezes maiores que a razão atmosférica, sugestivas de fonte profunda rica em gases; 4) existência de anomalias sísmicas profundas de baixa velocidade; 5) altas taxas de material ascendente no manto, maiores que $1 \mathrm{mg} / \mathrm{s}$. Se pelos menos 3 desses critérios forem satisfeitos, segundo os autores, há garantia que o vulcanismo observado seja resultante de uma pluma do manto. É importante notar que o primeiro critério postulado em Courtillot et al. (2003) é a própria definição de hot spot conforme a proposição de Wilson (1963). 
A partir desses aspectos, Anderson $\left(2005^{\mathrm{a}}\right.$ ) revisou e ampliou o número de critérios para a identificação de vulcanismo relacionado a hot spots. Neste trabalho, o autor aponta que a origem do magmatismo intraplaca e do magmatismo ao longo das dorsais meso-oceânicas a partir do modelo de plumas é controverso e baseado em critérios relativamente arbitrários. Dos 49 possíveis hot spot identificados por Courtillot et al. (2003), apenas 10 foram considerados pelos autores com possíveis origens vinculada a anomalias térmicas na interface manto-núcleo ( $>2900 \mathrm{~km}$ de profundidade).

De acordo com Anderson $\left(2005^{\mathrm{b}}\right)$, os gigantescos volumes de magma das províncias basálticas representam em primeira instância anomalias de fusão do manto e podem estar associada a fenômenos tectônicos relativamente rasos dominados por processos inerentes ao modelo de tectônica de placas, tais como: campo de tensão regional, regime tectônico, arquitetura crustal e por particularidades composicionais da astenosfera.

Além dos critérios expostos acima, a curta duração do evento magmático da ordem de 1 a 3 milhões de anos foi considerada por outros autores como um critério adicional para a distinção de vulcanismo relacionado a plumas do manto (Hoffman et al. 1997, Hoffman et al. 2000, Jackson et al. 2000).

A existência de padrões geométricos de enxames de diques do ínicio do Mesozoico circunjacentes às bordas do rift no Atlântico Central, descritos por May (1971) como enxames radiais formados durante a condição pré-drift dos continentes, também auxiliou na aceitação do modelo de plumas para a explicação das grandes províncias basálticas.

Seguindo este modelo, baseando-se na geometria e na extensão de enxames de diques, principalmente em enxames gigantes (comprimento $\geq 300 \mathrm{~km}$ ), Ernst \& Buchan (1997, 2001) consideraram estas feições como importantes indicadores da atividade de plumas do manto. Através da observação do padrão geométrico de diferentes enxames de diques com idades desde o Arqueano até o Neógeno, os autores subdividiram enxames de diques de diferentes partes do planeta em três classes geométricas principais: linear, radial e arqueado, com algumas variações e composições entre esses padrões principais. Os enxames lineares estariam associados a processos de rifteamento; os grandes enxames em forma de arco, por sua vez, poderiam refletir mudanças no campo de esforços regional durante o alojamento na crosta, ou indicar deformações 
posteriores, enquanto os enxames de diques radiais estariam relacionados a fenômenos de rupturas continentais a partir de junções tríplices.

Os enxames de diques radiais, segundo Ernst \& Buchan (2001), são definidos como enxames que, de uma maneira geral, apresentam uma divergência em forma de arco com até 15 graus de abertura. Para os autores, enxames de diques radiais, estão geralmente associados a processos de fraturamento radial relacionado a fenômenos de soerguimento crustal causado por domeamento térmico, vinculado à presença de uma pluma do manto na base da litosfera (Ernst \& Buchan 1997, Ernst \& Buchan 2001).

Mchone (2000) discute alguns fatos frequentemente esquecidos nos modelos vinculados a plumas do manto. Segundo o autor, especificamente para o caso do Atlântico Central, os basaltos do tipo CFB (continental flood basalts) presentes na porção E da América do Norte, W dá África e N da América do Sul se sobrepõem a eventos magmáticos intrusivos na forma de enxames de diques de diferentes tendências e afinidades composicionais supostamente incompatíveis com magmas gerados por uma mesma pluma. Esta consideração torna-se ainda mais controversa se levarmos em conta que nos modelos de pluma o manto é geralmente admitido como homogêneo e isotrópico. No caso do Atlântico Central, o magmatismo intraplaca é contemporâneo à formação da crosta oceânica, sendo que não existem evidências da presença de alguma trilha de ilhas oceânicas, comprovadamente integrantes de um sistema de hot-spot de idade máxima do Jurássico registrado na crosta oceânica do Atlântico Central.

Nos últimos anos, a integração de dados geológicos, geoquímicos, geocronológicos e geofísicos, bem como o aumento na precisão e qualidade desses resultados, os modelos das províncias basálticas têm passado por reformulações significativas, uma vez que o modelo clássico de plumas tem se mostrado incompatível com novas informações divulgadas por diferentes autores em distintas partes do mundo (King \& Anderson 1995, Anderson 1998, Smith \& Lewis 1999, Sheth 1999, Ernesto et al. 2002, Foulger 2003, Foulger et al. 2005).

Além disso, hipóteses alternativas estão sendo propostas nas quais o manto sublitosférico é heterogêneo, e os movimentos convectivos incapazes de promover sua completa homogeneização (Marques 2008). O que, de certa forma, poderia explicar as variações composicionais e os zoneamentos geoquímicos observados em várias províncias basálticas. Embora a origem, escala e natureza dessas heterogeneidades 
sejam ainda questões em debate, elas parecem desempenhar um papel muito importante na geração do magmatismo intraplaca e na geração das grandes províncias basálticas continentais (Anderson 1995, 2005 ).

Ao mesmo tempo, estudos baseados em aspectos tectônicos e estruturais em enxames de diques associados às províncias basálticas do Karoo e Atlântico Central mostraram discrepâncias em relação à geometria de enxames de diques máficos esperada nos modelos de plumas mantélicas (e.g. Ernst \& Buchan 1997, Ernst \& Buchan 2001), além do tempo envolvido na duração do magmatismo em regiões onde tais eventos foram atribuídos a estes modelos (McHone et al. 2005, Jourdan et al. 2006, Beutel 2005, 2009).

Assim, especialmente na última década do século passado, uma série de trabalhos baseados fundamentalmente no que conhecemos como a moderna teoria da tectônica de placas vem propondo que a origem das grandes províncias basálticas está vinculada a heterogeneidades na astenosfera causadas pela evolução dos próprios processos tectônicos vinculados a zonas de fraqueza da própria litosfera $(e . g$. Fouger et al. 2005). 


\section{O MAGMATISMO EOCRETACEO E A ABERTURA DO OCEANO ATLÂNTICO SUL}

No processo de ruptura do Pangea durante o Eocretaceo, a consequente geração do Oceano Atlântico Sul está relacionada a duas grandes províncias magmáticas: Paraná-Etendeka e Karoo (Figura 11), além das espessas elevações vulcânicas de Rio Grande e Walvis (White \& McKenzie 1989). A província do Karoo representa a segunda maior manifestação de lavas basálticas do planeta, com aproximadamente $2.000 .000 \mathrm{~km}^{2}$ de área aflorante e um volume de rochas estimado em $1.400 .000 \mathrm{~km}^{3}$ (Wilson 1989).

Por sua vez, a porção sul-americana da província Paraná-Etendeka, Formação Serra Geral (White 1908, Gordon Jr. 1947), constitui a terceira maior província de basaltos continentais com uma área aflorante em torno de $1.200 .000 \mathrm{~km}^{2}$, um volume de magma da ordem de $800.000 \mathrm{~km}^{3}$ e espessura máxima preservada de $1.720 \mathrm{~m}$ junto ao depocentro da Bacia do Paraná (Amaral et al. 1966, Piccirilo \& Melfi 1988). A sucessão vulcânica da Formação Serra Geral da Bacia do Paraná é dominada por basaltos e basaltos andesíticos de filiação toleítica, com porções subordinadas de riodacitos e riolitos. Além desses litotipos, são comuns níveis de soleiras de diabásio e gabro e diques de diabásio. São ainda conhecidas ocorrências de fácies magmáticas efusivas na forma de depósitos piroclásticos em regiões restritas no sudoeste do Paraná (Wildner et al. 2006).

Do lado africano, na região costeira da Namíbia, Angola, Congo e Gabão ocorrem derrames e enxames de diques de rochas predominantemente basálticas relacionadas ao mesmo evento, constituindo a porção africana da Província Magmática Paraná-Etendeka. No continente africano, o vulcanismo basáltico (Grupo Etendeka, no sul e norte da Namíbia, além de ocorrências isoladas nas bacias de Luanda e Kwanza) abrange uma área de aproximadamente $80000 \mathrm{~km}^{2}$ (Piccirillo et al. 1990, Renne et al. 1992, Turner et al. 1994, Peate et al. 1997, Jerram et al. 1999, Ewart et al.2004). 


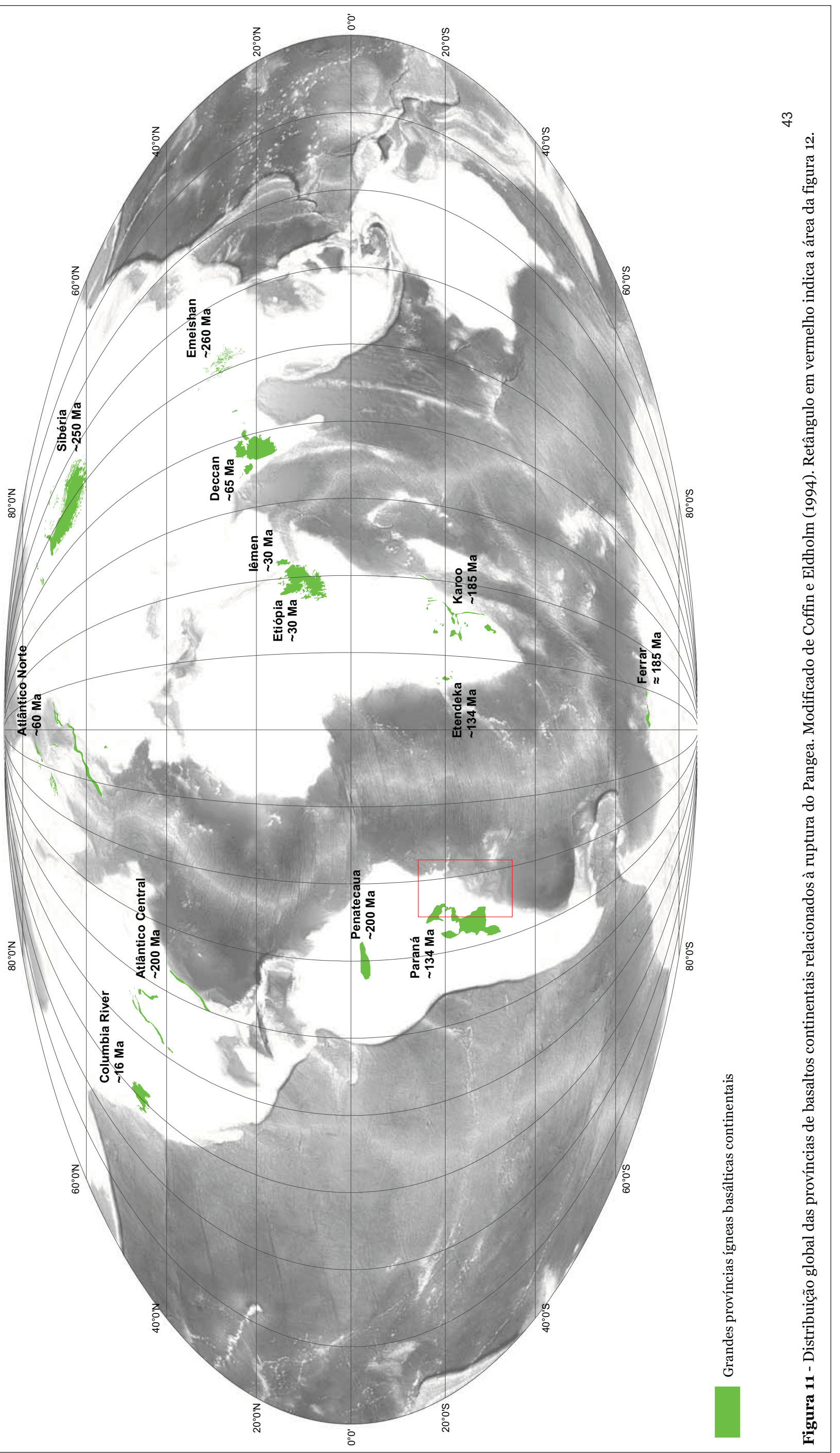


De acordo com Milner et al. (1995), a distribuição das idades das rochas vulcânicas encontradas na Província Magmática de Etendeka (137-128 Ma) é praticamente a mesma observada na Província Magmática do Paraná, mostrando claramente o sincronismo entre os eventos.

Diversos trabalhos demonstram as semelhanças petrológicas, geoquímicas e isotópicas existente entre as rochas ácidas, básicas e intermediárias da Formação Serra Geral com as rochas vulcânicas do Grupo Etendeka na Namíbia e em ocorrências isoladas espalhadas pela costa e interior de Angola, Congo e Gabão (Erlank et al. 1984, Duncan et al. 1988, Milner et al. 1995, Peate 1997, Marzoli et al. 1999 Marques et al. 1999, Marsh et al. 2001 e Ewart et al. 2004).

A Província Basáltica Paraná-Etendeka mostra uma marcante assimetria na distribuição do volume de lavas, sendo a maior parte das rochas extrusivas concentradas sobre a placa Sul-Americana. Esta assimetria foi explicada de diferentes maneiras: (1) como barreira topográfica presente ao longo da margem do continente africano (White \& McKenzie 1989); (2) um deslocamento do centro de calor da pluma de Tristão da Cunha (O'Connor \& Duncan 1990); (3) cisalhamento simples assimétrico durante o rifteamento (Peate 1990); (4) diminuição da espessura da litosfera abaixo da Bacia Paraná (Thompson \& Gibson 1991); e (5) um gradiente de pressão horizontal do magma entre a zona de falha axial do rift e a Bacia do Paraná (Harry \& Sawyer 1992).

Os trabalhos de Almeida $(1967,1969,1972,1976)$ e Almeida et al. $(1996,2000)$ definiram o conceito de Plataforma Sul-Americana e os efeitos causados pela reativação tectônica do Mesozoico (Reativação Wealdeniana). Nestes trabalhos, com destaque para Almeida (1976), é proposto um modelo de evolução geológica da região adjacente à Bacia de Santos, a partir da fragmentação do Pangea durante o fim do Jurássico e início do Cretaceo. De acordo com o autor, as rochas vulcânicas encontradas na Bacia de Santos foram extravasadas durante o Eocretaceo e recobriam grande parte da porção continental incluindo os sedimentos paleozoicos da Bacia do Paraná, concomitante ao desenvolvimento da Falha de Santos (Figura 12).

Uma série de estruturas transversais aos traços estruturais do embasamento précambriano mostra uma complexa história de reativações tectônicas desde o Paleozoico até o recente. Na porção centro-sul da América do Sul, ao longo das bordas da Bacia do Paraná (Figura 13), ocorrem uma série de arcos, altos estruturais e flexuras reativados 


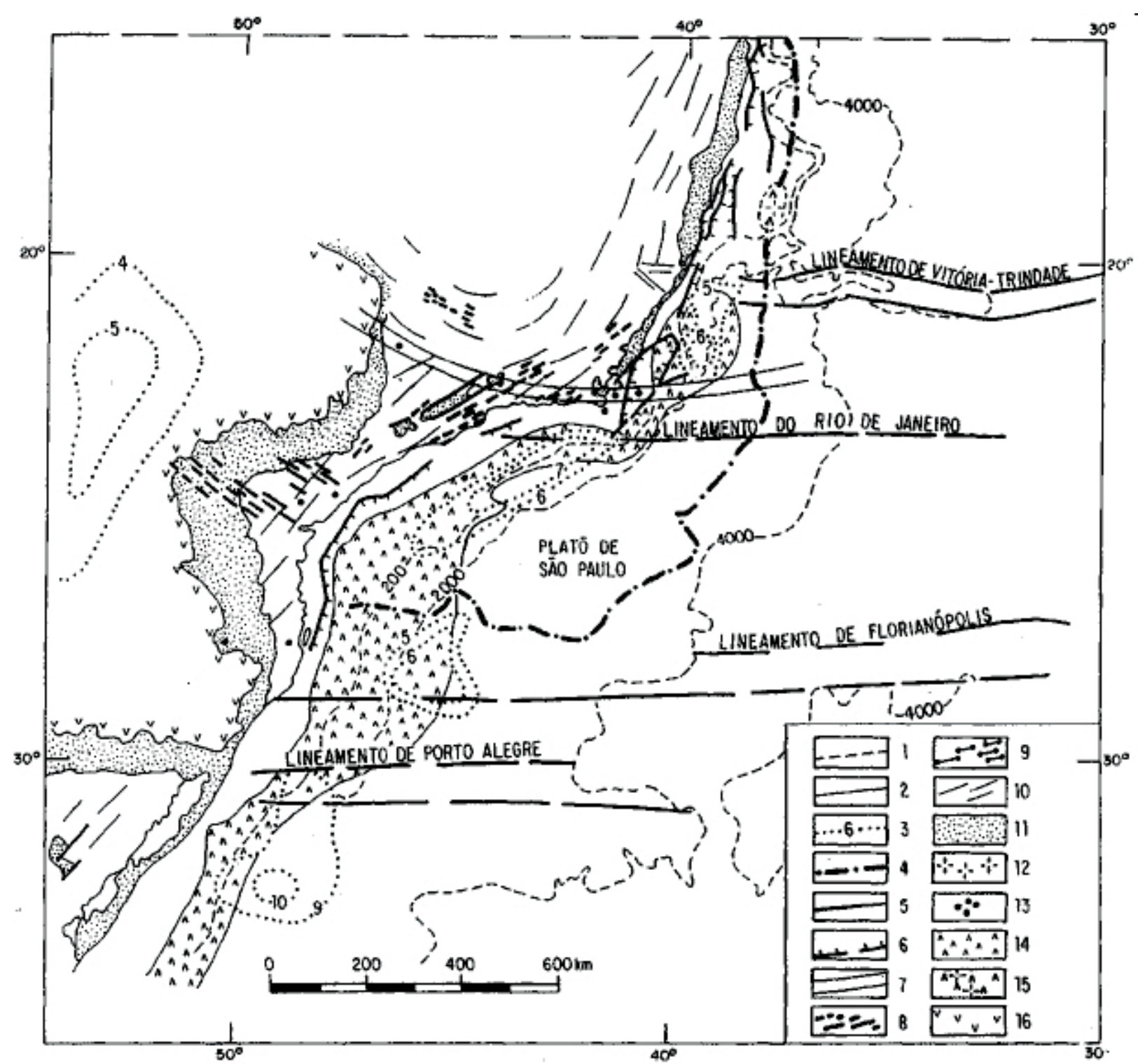

Figura 12 - Contexto regional do magmatismo mesozoico na região sul-sudeste do Brasil, segundo Almeida et al. (1996). Convenções cartográficas:1) cota batimétrica (m); (2) contato geológico ou limite do continente; (3) isópacas (km); (4) limite externo da zona de sal em subsuperfície; (5) zona defratura ou falhamento, (6) falha normal; (7) alinhamento magmático; (8) dique do Cretáceo Inferior; (9) dique do Permo-Triássico a Jurássico Inferior; (10) orientação das estruturas no embasamento; (11) bacia sedimentar; (12) rochas ígneas terciárias; (13) rochas alcalinas e álcali-cálcicas; (14) basalto do Cretáceo Inferior na região costeira sul-sudeste, em subsuperfície;(15) basalto do Cretáceo Inferior no Banco de Abrolhos, em subsuperfície; (16) basaltos na Bacia do Paraná. 


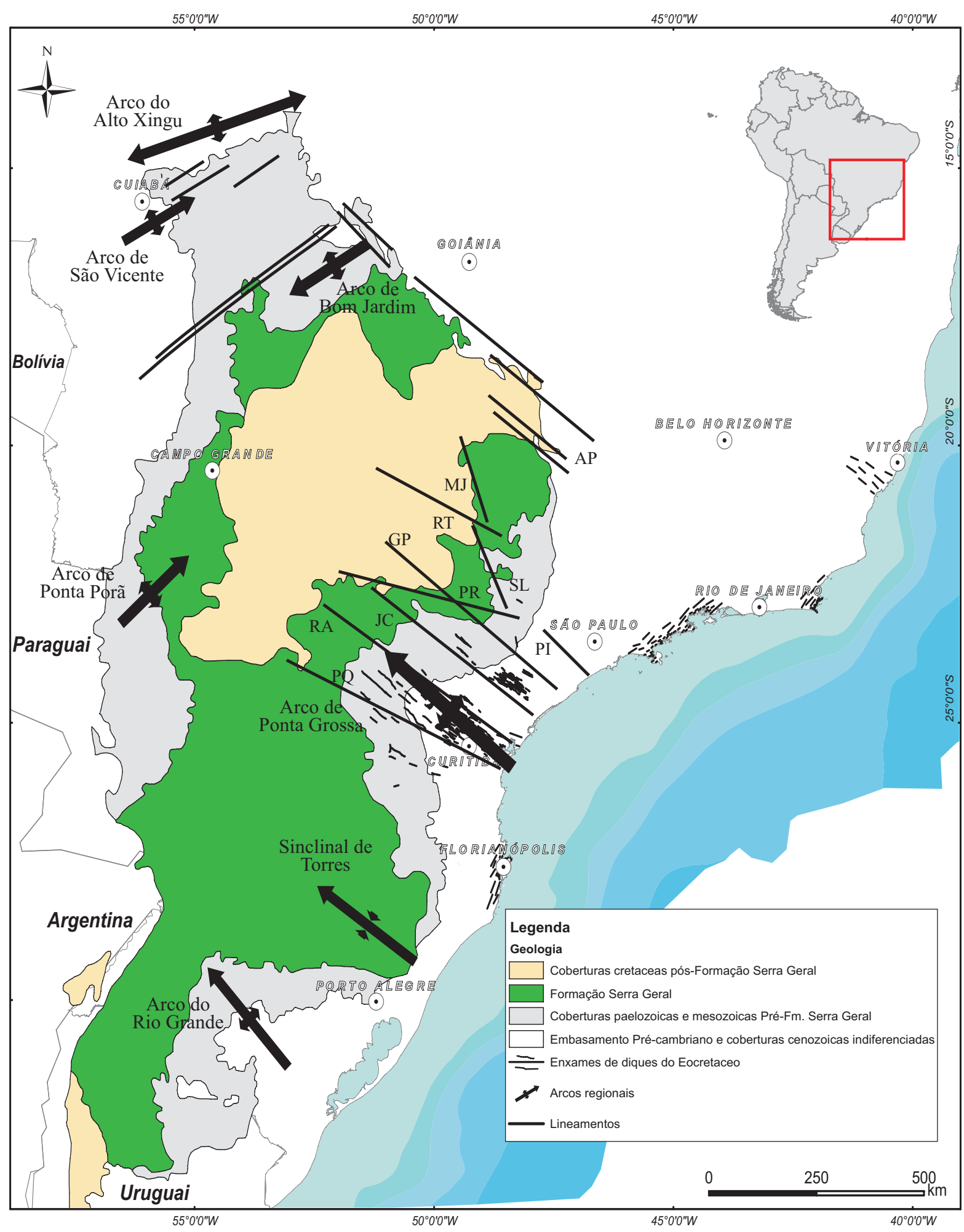

Figura 13 - Arcos, altos estruturais, lineamentos e flexuras transversais da Bacia do Paraná. Simplificado de Riccomini et al. (2005). Lineamentos estruturais (TBTransbrasiliano; AP-Alto Paranaíba; MJ-Moji-Guaçu; RT-Rio Tietê; SL-São Carlos-Leme; PR-Paranapanema; PI-Piedade; GP=Guapiara; JC-São Jerônimo-Curiúva; RA-Rio Alonzo; PQ-Rio Piquiri. 
e/ou neoformados ao longo do período de separação entre a América do Sul e a África. Sadowski (1987) apresenta um quadro de evolução dessas estruturas envolvendo reativações tectônicas e magmatismo pré e pós-ruptura. $\mathrm{O}$ autor levanta a hipótese de uma relação entre os eventos de reativações tectono-magmáticas aos mecanismos cinemáticos e mudanças de trajetórias envolvendo as placas sul-americana e africana.

Ao longo do desenvolvimento da margem continental, em especial o segmento central (Sul-Sudeste do Brasil), é indiscutível o controle exercido pela trama estrutural do embasamento na determinação da localização de falhas de borda, zonas de charneira, depocentros e altos estruturais geralmente paralelos a estruturas do embasamento précambriano (Almeida et al. 1986). Além disso, as descontinuidades e anisotropias do embasamento foram decisivas na delimitação de regiões com diferentes taxas de estiramento que operaram na crosta durante a evolução do rift do Atlântico Sul, conforme demonstrado por Chang \& Kowsmann (1984).

Piccirillo et al. (1988) apresentam um modelo envolvendo 4 estágios para o desenvolvimento do magmatismo da Província Magmática Paraná-Etendeka (Figura 14):

i) Estágio pré-rift - caracterizado pela presença de uma anomalia térmica do manto litosférico nas regiões afetadas pelos derrames da Formação Serra Geral e do Grupo Etendeka. A ascensão desta anomalia térmica seria a responsável pelo soerguimento generalizado do continente conforme a proposição de Asmus (1975) e Asmus \& Guazelli (1981).

ii) O segundo estágio seria marcado pela evolução da anomalia térmica no manto litosférico até o ínicio dos fenômenos de fusão parcial do mesmo, acompanhando a instrusão de magmas picríticos na crosta inferior (underplating) e extrusão de basaltos continentais. O vulcanismo neste estágio seria marcado por altas taxas de extrusão, mostrando uma polaridade de sul para norte, a partir da porção sul do atual Estado do Paraná. Para os autores, durante esta fase do processo de ruptura, a litosfera do Pangea teria sofrido distensão sem a ocorrência do rifteamento.

iii) O terceiro estágio seria caracterizado pelo aumento da distensão crustal iniciando assim o processo de rifteamento com afinamento litosférico e 

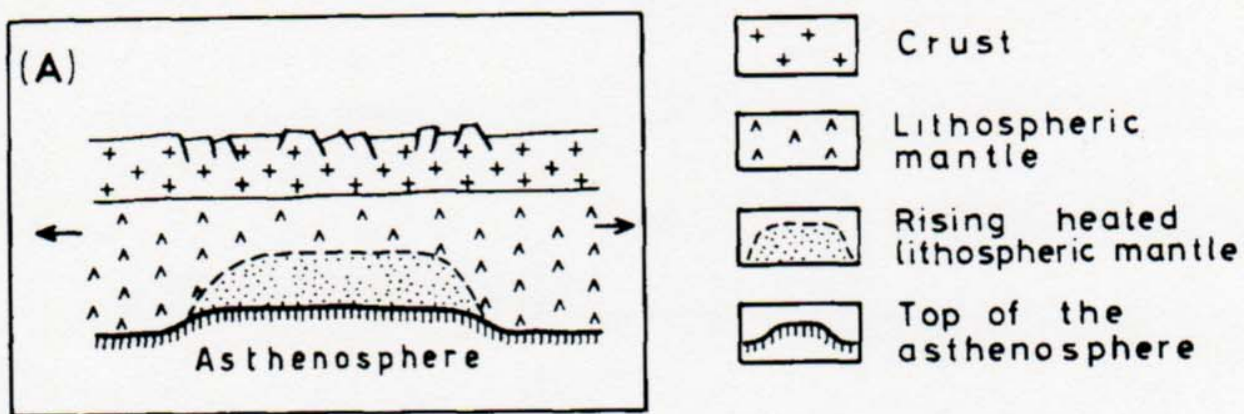

\section{PRE-RIFT STAGE (CRUSTAL UNDERPLATING)}

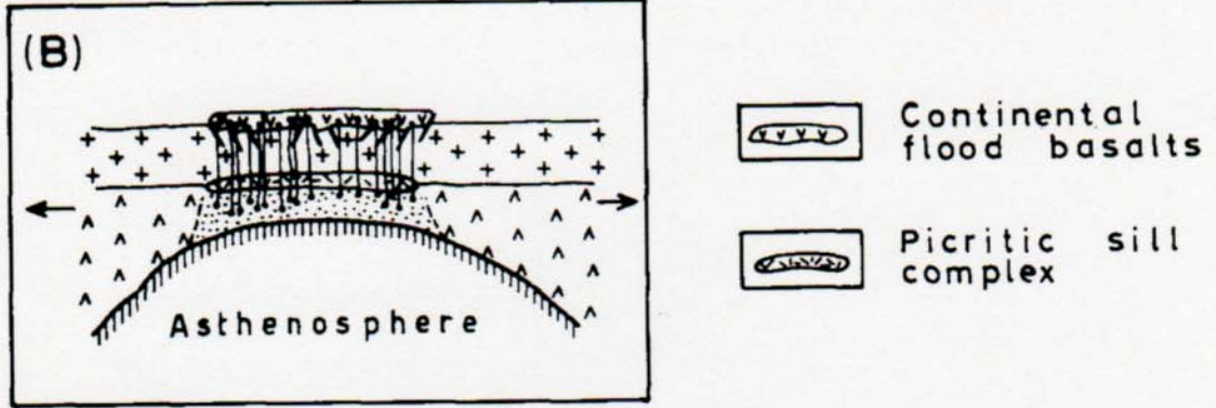

EARLY RIFTING (CRUSTAL THINNING)
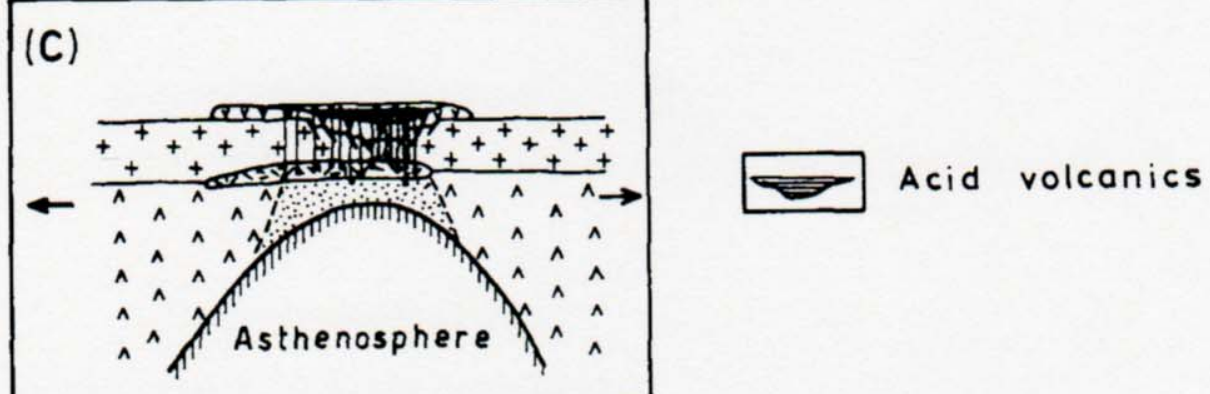

\section{MAJOR RIFTING $\rightarrow$ PROTO-OCEANIC CONDITIONS}
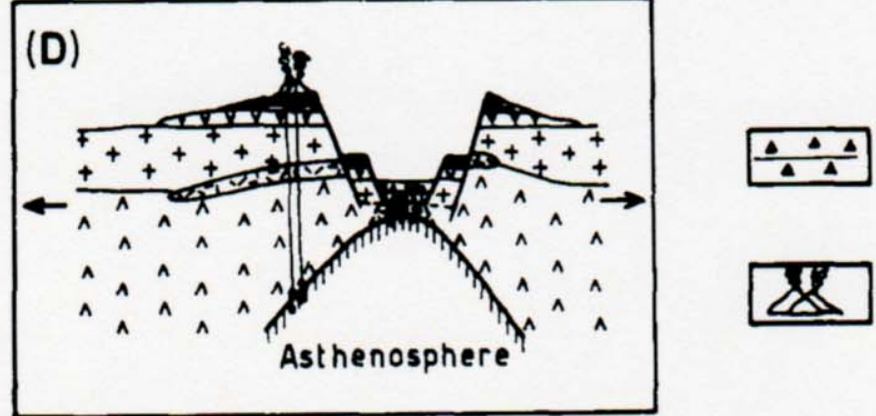

Continental-oceanic basalt types

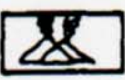

Alkaline magmatism

Figura 14 - Modelo evolutivo da Província Magmática Paraná-Etendeka durante a abertura do Oceano Atlântico Sul de acordo com Piccirillo et al. 1988. 
vulcanismo se propagando para leste. Apesar de não situar o evento no tempo, os autores consideram o enxame de diques de Ponta Grossa como representantes tardios do magmatismo.

iv) No quarto e último estágio, a distensão e afinamento litosférico atingiria o clímax do rifteamento, levando à ascensão da astenosfera e confinando o vulcanismo nas regiões de máxima subsidência do rift.

White \& McKenzie (1989), seguindo os modelos de Morgan (1971) e Burke \& Dewey (1973), sugerem que o Oceano Atlântico Sul é um bom exemplo de ruptura continental causada por uma anomalia térmica resultante da presença de uma pluma mantélica na base da crosta. Segundo os autores, tal anomalia seria a responsável pela geração de processos de fusão parcial do manto astenosférico e parte do manto litosférico originando os derrames basálticos da Província Paraná-Etendeka e das elevações vulcânicas submarinas de Walvis e Rio Grande. Neste modelo, a pluma responsável pela anomalia térmica estaria hoje posicionada abaixo da ilha vulcânica de Tristão da Cunha a uma distância de aproximadamente $400 \mathrm{~km}$ da Dorsal MesoAtlântica. Os autores consideram que o espalhamento do fundo oceânico entre a América do Sul e África iniciou no extremo sul da Bacia do Cabo, no mesmo período da anomalia magnética M9, ou seja, cerca de 128 Ma segundo Harland et al. (1990).

O’Connor \& Duncan (1990), baseados em idades ${ }^{40} \mathrm{Ar} /{ }^{39} \mathrm{Ar}$ de rochas vulcânicas basálticas da ilha de Tristão da Cunha e das elevações de Rio Grande e Walvis, argumentam a existência de uma pluma mantélica atuando a partir de uma área localizada nas imediações do Arco de Ponta Grossa, de onde se propagou todo o magmatismo encontrado nas elevações oceânicas e na Província Paraná-Etendeka.

Turner et al. (1994) propõem um modelo onde o magmatismo Serra Geral teria se formado como decorrência da atividade da pluma de Tristão da Cunha sob o continente sul-americano. Os autores descrevem o mecanismo de abertura do oceano Atlântico Sul caracterizado pela rotação no sentido horário da porção sul da América do Sul, com o desenvolvimento de processos deformadores indicados pela distensão NESW materializada nos enxames de diques de Ponta Grossa e do leste do Paraguai praticamente coetâneo ao evento de colocação dos diques da faixa costeira entre Santos e Rio de Janeiro. Ainda neste trabalho, fazem uma importante observação considerando que a faixa de direção NW-SE, onde ocorrem os diques de Ponta Grossa, tenha se 
comportado como uma zona de deformação transcorrente, não representando apenas o simples movimento da placa sul-americana sobre a pluma de Tristão da Cunha.

Diversos autores abordaram o problema da cronologia dos eventos responsáveis pela abertura do Oceano Atlântico Sul através de técnicas de reconstituições paleogeográficas (e.g. Bullard et al. 1965, Rabinowitz \& LaBrecque 1979, Vink 1982, Pindell \& Dewey 1982, Curie 1984, Nürnberg e Müller 1991, Lawver et al. 1999, Schettino \& Scotese, 2005, Eagles 2007, König \& Jokat 2006, Torsvik et al. 2009, Moulin et al. 2010). A construção desses modelos é feita com base em interpretações das anomalias magnéticas do fundo oceânico, isócronas das anomalias, linhas de fluxo das falhas transformes, geometria das zonas de fratura oceânica e continental e datação radiométrica de rochas ígneas relacionadas ao evento. De acordo com Moulin et al. (2010), todos os modelos apresentam divergências (lacunas, sobreposições e distorções) e incompatibilidades no que diz respeito as idades das anomalias magnéticas e dinâmica da deformação intraplaca. Exceto os modelos de Torsvik et al. (2009) e Moulin et al. (2010), os outros foram construídos considerando a premissa da rigidez das placas tectônicas e da deformação concentrada nos limites das mesmas.

Com base no mapeamento de anomalias magnéticas a sul das elevações Walvis e do Plateau de São Paulo, Rabinowitz e La Brecque (1979) apresentaram o primeiro modelo cinemático para a ruptura da porção sul do Pangea, segundo o qual os continentes se movimentaram como blocos rígidos ao longo de uma distensão de direção E-W durante o Neocomiano (145.5-130 Ma). Os autores consideram que o espalhamento do fundo oceânico no Atlântico Sul iniciou-se por volta de $138 \mathrm{Ma}$ marcado pela anomalia magnética M12.

Nürnberg \& Müller (1991) formularam um modelo onde a abertura do Oceano Atlântico Sul ocorre a partir da propagação de um rift iniciado no extremo sul do Pangea. De acordo com o modelo, entre $150 \mathrm{Ma}$ e cerca de $130 \mathrm{Ma}$ o rifteamento atingiu a região do paralelo $38^{\circ} \mathrm{S}$, causando deformação tectônica nas bacias Colorado e Salado na Argentina. Posteriormente, entre 130 e 126,5 Ma, correspondente a anomalia magnética M4, a polaridade do rift avançou para o paralelo $28^{\circ} \mathrm{S}$, resultando em deformação intracontinental ao longo da zona de deformação da Bacia Paraná-Chaco. No intervalo de tempo compreendido entre as anomalias magnéticas M4 e M0 (126,5118,7 Ma), o rifteamento atingiu a atual região da Nigéria, próximo a latitudes 
equatoriais. O Atlântico Equatorial começou a abrir apenas após a formação da anomalia M0 (118,7 Ma). Neste intervalo de tempo teriam ocorrido deformações intracontinentais ao longo de zonas de fraqueza pré-existentes no embasamento précambriano. De acordo com os autores, a abertura do Atlântico Sul a partir de $84 \mathrm{Ma}$ (Chron 34) é caracterizada pela simples divergência de duas placas continentais rígidas.

Bueno (2004) separa a ruptura da porção meridional do Atlântico Sul em três fases de break-up. De acordo com o modelo proposto por este autor, o início da propagação do rift ocorreu no extremo sul da América do Sul, a partir das Falklands até os afloramentos atuais dos basaltos da Formação Serra Geral em Torres, no Rio Grande do Sul, coincidindo com a anomalia magnética M11 (132 Ma segundo Gradstein et al. 1995). Posteriormente, a propagação se processou da porção norte da Bacia de Pelotas até o sul da Bacia de Santos, concomitante a formação da anomalia M3 (126 Ma segundo Stewart et al. 1996). A terceira fase ocorreu por volta de $115 \mathrm{Ma}$, do norte da Bacia de Santos até aproximadamente a porção submersa da Bacia Sergipe-Alagoas. Para esta fase, não foram reconhecidas anomalias magnéticas equivalentes na crosta oceânica. Para o autor, existe um claro diacronismo entre as gerações de Seawarddipping reflectors (refletores mergulhantes para o mar), os enxames de diques e a formação da crosta oceânica.

A evolução tectônica da margem continental atlântica sul-americana é relativamente complexa e marcada por múltiplos eventos, compreendendo, sucessivamente, o magmatismo toleítico eocretaceo da Formação Serra Geral, a instalação das bacias marginais, o magmatismo neocretaceo-paleoceno, além de eventos tectônicos e magmáticos posteriores (e.g Riccomini \& Assumpção 1999, Riccomini et al. 2004, Zalán 2004).

De acordo com Riccomini et al. (2006), o magmatismo extrusivo teve início em $137 \mathrm{Ma}$ ao longo de alinhamentos de direção NE, coincidente com a atual calha do Rio Paraná, e posteriormente migrou para SE, com intensa atividade magmática intrusiva na forma de enxame de diques ao longo de alinhamentos de direção NW-SE, que constituem o Arco de Ponta Grossa entre 131 e 130 Ma. Adiante, o magmatismo intrusivo teve lugar ao longo das regiões costeiras dos estados de Santa Catarina, Paraná, São Paulo e Rio de Janeiro, em parte aproveitando antigas estruturas do 
embasamento de direção NE-SW a ENE-WSW, até atingir o continente africano na região da Namíbia e Congo há cerca de 127 Ma.

Por outro lado, Torsvik et al. (2009) propõem um novo modelo para os mecanismos e o tempo envolvido no processo de abertura do Atlântico Sul. Baseandose em novas interpretações e mapeamento por métodos indiretos (batimetria, gravimetria, magnetometria, sísmica de reflexão/refração) do limite crosta continentalcrosta oceânica, das coberturas evaporíticas aptianas, e considerando a cronologia da atividade magmática bem como a deformação intraplaca contemporânea ao evento, os autores propõem que as bacias marginais brasileiras, juntamente com suas margens conjugadas no lado africano (Angola, Congo, Gabão), representaram até aproximadamente o limite Aptiano-Albiano $(\approx 112 \mathrm{Ma})$ uma única bacia sin-rift, posicionada em latitudes subtropicais $\left(10^{\circ} \mathrm{S}-27^{\circ} \mathrm{S}\right)$.

O modelo admite que a expansão do fundo oceânico nessas latitudes iniciou-se a norte das elevações de Rio Grande e da Cadeia de Walvis contemporaneamente ao magmatismo da Província Paraná-Etendeka em torno de 132 Ma (Barremiano), antes da anomalia M4. Os autores consideram o magmatismo da Província Paraná-Etendeka relacionado à atividade termal da pluma de Tristão da Cunha. De acordo com o modelo proposto, a expansão do assoalho oceânico no Atlântico Sul começou na margem continental da Argentina na Bacia de Colorado em torno de 134-131 Ma. Este período é marcado pela anomalia M11, não reconhecida na margem continental da América do Sul (Eagles 2007, Torsvik et al. 2009).

Moulin et al. (2010), em trabalho praticamente simultâneo ao de Torsvik et al. (2009), também apresentam um modelo de reconstituição paleogeográfica e cinemática da abertura do Atlântico Sul. Baseando-se na identificação de anomalias magnéticas, isócronas radiométricas do fundo marinho, linhas de fluxo com geometria das zonas de fraturas oceânicas e de estruturas do embasamento pré-cambriano, demonstram uma complexa relação envolvendo a ruptura da crosta continental, o magmatismo intraplaca e interplaca e a deformação intracontinental registrada durante a abertura do Atlântico Sul. De acordo com o modelo destes autores, a primeira crosta oceânica no Atlântico Sul surgiu entre as anomalias M9 e M7, no intervalo entre 134-130 Ma. No segmento central do Atlântico Sul, os autores acreditam que a formação da primeira crosta oceânica surge no limite Albiano-Aptiano $(\approx 112 \mathrm{Ma})$, após o extravasamento dos 
basaltos da Província Paraná-Etendeka (136-125 Ma). Os autores postulam que, durante a ruptura do continente, parte da deformação foi acomodada através de movimentações horizontais, do tipo strike-slip.

De acordo com os critérios propostos em Courtillot et al. (2003), a ilha oceânica de Tristão da Cunha representa um hot spot primário que teria originado, através do impacto termal exercido na base da litosfera, a província magmática Paraná-Etendeka. Segundo esta hipótese, as cadeias submarinas de Rio Grande e Walvis representam os registros deixados por esta pluma no assoalho oceânico durante a migração deste. Datações ${ }^{40} \mathrm{Ar} /{ }^{39} \mathrm{Ar}$ em basaltos de Walvis, segundo Müller et al. (1993), mostram uma progressão das idades de 113 a 30 Ma. Sleep (1990), através do estudo de anomalias do geóide, determinou uma taxa de material ascendente da ordem de $1,7 \mathrm{mg} / \mathrm{s}$, satisfazendo mais um dos critérios propostos por Courtillot et al. (2003). As baixas razões isotópicas ${ }^{3} \mathrm{He} /{ }^{4} \mathrm{He}$ encontradas nas rochas vulcânicas de Tristão da Cunha (Farley \& Neroda 1998) e a ausência de anomalias de baixa velocidade sísmica no manto subjacente $(660 \mathrm{~km})$ determinadas por Ritsema \& Allen (2003) e Montelli et al. (2006) foram os dois critérios não atendidos para a confirmação do envolvimento de plumas na gênese da Província Paraná-Etendeka.

No entanto, trabalhos realizados por Anderson (2005 $\left.5^{\mathrm{a}}, 2005^{\mathrm{b}}\right)$, Baksi (2005) e Fouger (2010) questionam uma série de argumentos e premissas assumidas nos modelos de pluma, e de certa forma, retomam a hipótese de Hawkesworth \& Gallagher (1993), vinculando a origem das grandes províncias basálticas, como produtos diretamente relacionados a grandes eventos de fusão do manto aos processos conhecidos da tectônica de placas.

A despeito de toda discussão sobre a existência, origem e evolução de plumas do manto, idades radiométricas e pólos paleomagnéticos demonstram a ocorrência de uma migração da atividade vulcânica de sul para norte o que, segundo Marques \& Ernesto (2004), inviabilizaria o modelo proposto por O'Connor \& Duncan (1990) e Turner et al. (1996). Ernesto et al. (2002) e Marques \& Ernesto (2004) afirmam ainda que, em reconstruções paleogeográficas da Placa Sul-americana por volta de $133 \mathrm{Ma}$, a região afetada pelo magmatismo Serra Geral estava distante pelo menos $1000 \mathrm{~km}$ da ilha vulcânica de Tristão da Cunha e que, portanto, não poderia ter contribuído de maneira significativa como fonte de calor para a fusão do manto litosférico subcontinental. 
Nesse contexto, cabe ainda lembrar a gritante assimetria no volume e área de exposição de rochas vulcânicas quando realizada a comparação entre a porção sul-americana e o lado africano.

Uma alternativa para ao modelo de pluma foi apresentada por Ernesto et al. (2002), onde a fonte de calor necessária para a geração do magmatismo estaria relacionada às extensas anomalias térmicas do manto profundo, indicada em estudos de tomografia sísmica e por anomalias do geóide, e ainda não totalmente dissipada localizada na costa oeste do continente africano.

A concentração da atividade magmática durante o Mesozoico na porção centroleste do Pangea, mais especificamente nas atuais regiões sul-sudeste da América do Sul (Província Magmática Paraná) e sua contra parte no extremo oeste do continente africano na Província Magmática de Etendeka (Namíbia e Congo), corrobora a existência de uma enorme anomalia térmica em uma região relativamente pequena (Província Paraná-Etendeka) (Piccirillo et al. 1988). De acordo com Bott (1971), anomalias como esta seriam responsáveis pela geração de mudanças nas propriedades reológicas da crosta, tornando-a mais fraca e suscetível a processos de rupturas gerados por esforços distensivos.

Em relação ao magmatismo intrusivo (soleiras e enxames de diques), Ernst e Buchan (1997) propõem um modelo onde os enxames de diques do Arco de Ponta Grossa, Serra do Mar e Florianópolis fazem parte de um grande sistema radial, causado pelo soerguimento da litosfera devido à influência da pluma de Tristão da Cunha. Este modelo também não encontra respaldo em datações radiométricas e resultados paleomagnéticos, que mostram a existência de diferentes episódios de colocação de diques, com diferença significativa entre as idades (Marques \& Ernesto 2004). 


\section{1 - A Formação Serra Geral: definição e unidades cronocorrelatas na porção Sul-Sudeste da América do Sul}

A primeira referência formal às rochas vulcânicas da Formação Serra Geral aparece no trabalho de White (1908) na tentativa de estabelecer uma coluna estratigráfica para a Bacia do Paraná. Neste trabalho, o autor denominou de "eruptivas da Serra Geral" à sucessão de rochas basálticas que afloram na porção oriental da Bacia do Paraná. A denominação utilizada faz referência às escarpas do platô vulcânico aflorante em grande parte da porção Sul-Sudeste do Brasil. Na concepção de White (1908), as "Eruptivas da Serra Geral" representavam toda a sucessão de rochas vulcânicas em sua maioria basálticas sobrepostas, e localmente intercaladas, a Grés de São Bento. A esta sucessão litoestratigráfica White (1908) denominou de Série São Bento, com idade entre o Jurássico e o Cretaceo. A Grés de São Bento corresponderia a Grés de Botucatu, conforme inicialmente descrita por Gonzaga de Campos (1889), posteriormente redefinida como Formação Botucatu (Sanford \& Lange 1960).

De certa forma, a denominação Formação Serra Geral como conhecemos atualmente se deve ao trabalho clássico de Gordon Jr. (1947), onde o autor definiu esta unidade como formada por rochas vulcânicas extrusivas com intercalações de arenitos eólicos. As rochas vulcânicas são basaltos amigdaloidais, subordinadamente com estrutura maciça e/ou colunar. Apesar de ocorrerem intercalações entre os basaltos da Formação Serra Geral e os arenitos da Formação Botucatu, Gordon Jr. (1947) descreve o contato entre as duas unidades como marcado por uma discordância.

Apesar de a denominação Formação Serra Geral estar amplamente difundida e aceita pela literatura geológica nacional, Rocha-Campos et al. (1988) apontam alguns problemas em sua formalização como unidade de mapeamento, principalmente no que diz respeito aos contatos inferior com a Formação Botucatu e superior com a Formação Caiuá (sensu Sanford \& Lange 1960). Além dessas duas unidades, em alguns locais da Bacia do Paraná, a Formação Serra Geral encontra-se sobreposta diretamente a rochas sedimentares do Grupo Passa Dois e sobre o embasamento pré-cambriano (Freitas 2009).

Outro fator de controvérsias diz respeito à ocorrência de derrames e corpos subvulcânicos de rochas ígneas de composição básica a intermediária. Tais ocorrências 
foram inicialmente descritas por Leinz (1949) e representam uma grande extensão em área e volume e encontram-se igualmente reunidas sob a denominação Formação Serra Geral.

Bellieni et al. (1984) reconheceram a divisão geoquímica e geográfica existente nas rochas magmáticas da Formação Serra Geral de acordo com a distribuição dos teores de Ti encontrados na pilha de rochas vulcânicas. Segundo os autores, abaixo do lineamento Rio Uruguai, na porção SE da Província Magmática Paraná ocorrem rochas vulcânicas com baixos teores de Ti e elementos incompatíveis (P, Sr, Zr, La, Ce e Ba), enquanto na porção NW, especificamente acima do lineamento Rio Piquiri, ocorrem predominantemente rochas com elevado teor de Ti e elementos incompatíveis.

De uma maneira geral, as rochas magmáticas da Província Paraná apresentam composição bimodal, com um hiato de sílica maior que $10 \%$ em teor, sendo que a quase totalidade dessas rochas possuem caráter composicional básico (90\%), enquanto 7,5\% representam rochas de composição intermediária, e apenas 2,5\% é representado por rochas de caráter ácido (Bellieni et al. 1986; Nardy et al. 2002).

As rochas de caráter básico e intermediário apresentam ampla distribuição geográfica, sendo comuns a toda Província Paraná e representadas por basaltos e andesitos toleíticos. Com base nos conteúdos de Ti, Zr, Y, Sr, e Ba, juntamente com as observações de Bellieni et al. (1986), Peate et al. (1992) atribuíram as diferenças entre os dois grandes grupos de rochas vulcânicas a diferentes tipos de magma, sendo eles: basaltos de baixo Ti - Ribeira, Esmeralda e Gramado; basaltos de alto Ti - Urubici, Pitanga e Paranapanema. Posteriormente, os basaltos do tipo Ribeira foram reclassificados e inseridos no grupo de alto Ti por Peate (1997).

As rochas de caráter ácido ocorrem mais expressivamente na parte meridional da província, onde aparecem geralmente no topo da sucessão vulcânica, sobrepostas aos derrames de caráter básico. Mantovani et al. (1985) e Bellieni et al. (1986) dividiram essas rochas em dois tipos principais, o tipo Palmas, formado dominantemente por riolitos e dacitos com baixos teores de Ti; e o tipo Chapecó, representado por dacitos, riodacitos, quartzo-latitos e riolitos, ambos com elevado teor de Ti.

Na região centro-sul do Rio Grande do Sul, entre os municípios de Santana da Boa Vista e Canguçu ocorrem derrames de rochas vulcânicas preservados no gráben do 
Moirão (sensu Tomba 2006) recobrindo rochas do Grupo Rosário do Sul. Estas rochas foram estudadas por Figueró et al. (1996), onde os autores identificaram a existência de pelo menos dois derrames, um de afinidade básica e outro de caráter intermediário, agrupando as ocorrências de rochas vulcânicas em uma nova unidade litoestratigráfica, denominada de Formação Passo das Carretas. Idades ${ }^{40} \mathrm{~K} /{ }^{40} \mathrm{Ar}$ obtidas pelos autores indicaram valores entre 137 Ma para os litotipos básicos e $126 \mathrm{Ma}$ para litotipos intermediários. Tomba (2006) correlaciona as rochas da Formação Passo das Carretas diretamente com as rochas vulcânicas da Formação Serra Geral, baseando-se nos aspectos geoquímicos, petrográficos e nas idades apresentadas em Figueró et al. (1996).

Ainda no Rio Grande do Sul, próximo à fronteira com o Uruguai, CominChiaramonti et al. (2010) descrevem a ocorrência de rochas vulcânicas ácidas ricas em cordierita. As idades apresentadas $\left(157 \pm 5 \mathrm{Ma}\right.$ e $\left.139.6 \pm 7.4 \mathrm{Ma}{ }^{40} \mathrm{Ar} /{ }^{39} \mathrm{Ar}\right)$ mostram-se relativamente acima do intervalo de idades normalmente admitidos para o evento Serra Geral. Os autores vinculam a origem dessas lavas a processos de fusão parcial relacionados a reativações de falhas. Possivelmente essas rochas representam manifestações iniciais do vulcanismo, uma vez que a reativação dessas falhas deve estar associada aos processos de distensão crustal antecedentes ao período principal de ruptura do Pangea.

\section{2 - Posicionamento crononoestratigráfico do magmatismo Serra Geral e eventos correlatos nas bacias marginais do Sul-Sudeste brasileiro}

Na costa leste da América do Sul, especificamente na porção central do Oceano Atlântico, existe uma série de bacias sedimentares, em sua maioria submersas, que representam o registro geológico da evolução do rift do Oceano Atlântico Sul, até o estabelecimento da atual margem passiva sul-americana (Figura 15). De acordo com Chang et al. (1988), a porção brasileira da margem continental do centro-sudeste da América do Sul compreende seis bacias sedimentares (Sergipe-Alagoas, Bahia Sul, Espírito Santo, Campos, Santos e Pelotas), posteriormente Milani \& Thomaz Filho (2000) subdividiram a bacia de Bahia Sul nas bacias de Jacuípe, Camamu, Almada, Cumuruxatiba, Jequitinhonha e Mucuri. Estas bacias, com exceção de Sergipe-Alagoas e Bahia Sul possuem em suas colunas estratigráficas sucessões vulcânicas e sedimentares descontínuas, separadas por hiatos deposicionais e discordâncias regionais que datam desde o Cretaceo até o recente, sendo que em algumas delas é confirmada a 


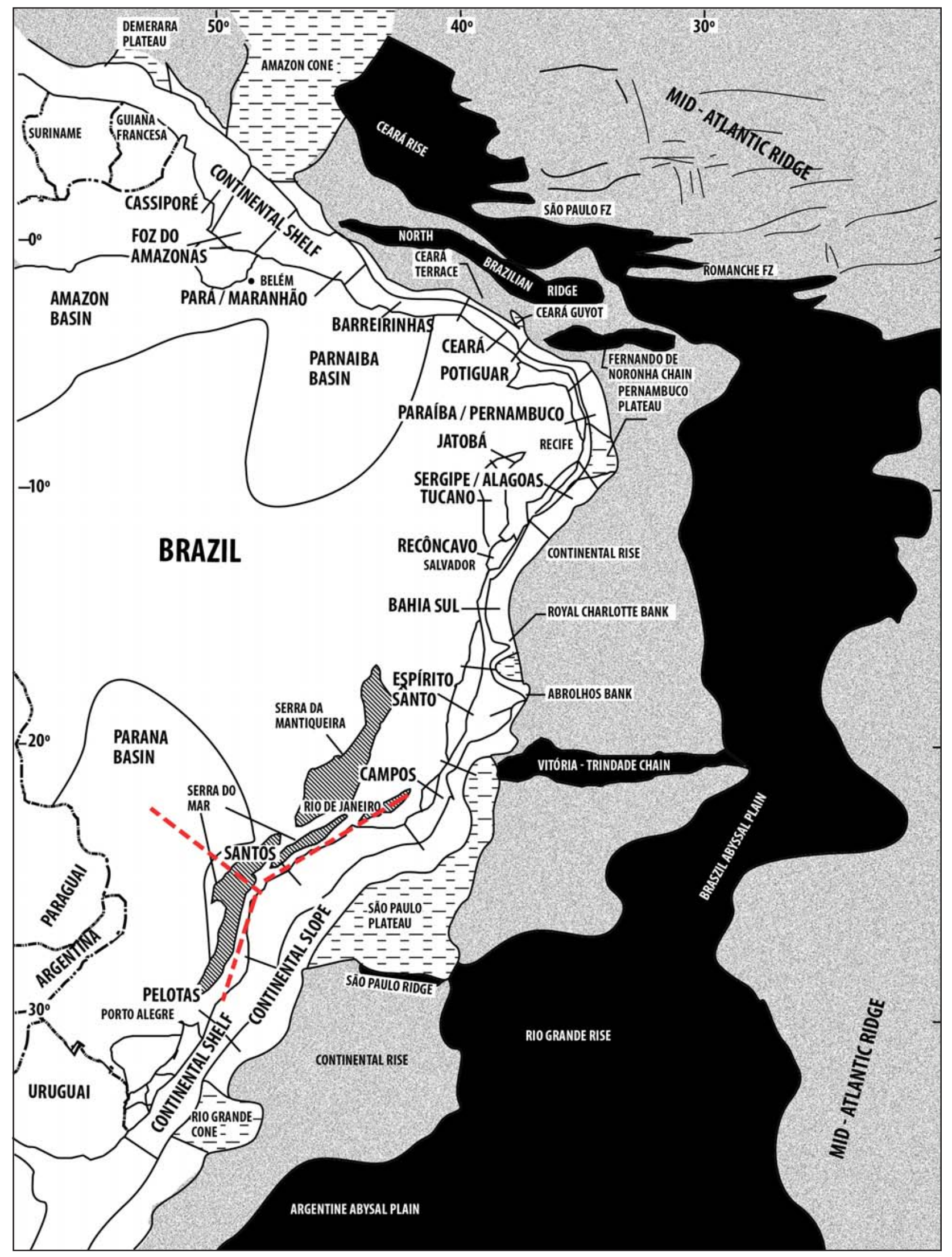

Figura 15 - Bacias sedimentares brasileiras da Margem Continental Atlântica da América do Sul. As linhas tracejadas em vermelho representam os enxames de diques máficos eocretaceos do Sul-Sudeste do Brasil. Adaptado de Chang et al. (1992). 
presença de rochas sedimentares paleozoicas na forma de embasamento pré-rift. Nas bacias de Santos, Campos e Espírito Santo são marcantes as deformações causadas por influência da movimentação dos níveis evaporíticos (Mohriak et al. 2008).

As primeiras classificações das bacias marginais brasileiras no contexto da tectônica de placas foram realizadas por Estrella (1972) e Asmus \& Porto (1972). Posteriormente Asmus \& Ponte (1973) e Ponte \& Asmus (1978) subdividiram a evolução das bacias marginais em quatro estágios evolutivos: pré-rift, rift, protooceânico e margem continental.

Asmus \& Porto (1980) interpretam a margem continental brasileira em dois estilos de rifteamento principais: dômico (bacias de Campos e Santos), e interdômico (bacias de Sergipe-Alagoas e Bahia Sul). Os principais critérios considerados nesta classificação foram a existência de sedimentos pré-rift e a presença de vulcanismo.

Asmus \& Guazelli (1981), no trabalho clássico sobre a evolução da margem continental brasileira, apontam a existência de um evento de soerguimento dômico generalizado da porção SE do Brasil a partir do fim do Permiano ao Triássico, que acarretou na geração de importantes manifestações magmáticas (vide Riccomini et al. 2005) resultantes de perturbações térmicas no manto. Segundo os autores, após o evento de soerguimento seguiu-se o estágio de rift-valley caracterizado pela presença generalizada de estruturas distensionais, principalmente falhamentos normais que resultaram nas bacias da porção $\mathrm{S}$ e $\mathrm{SE}$ da margem continental brasileira, mais especificamente as bacias do Pelotas, Santos, Campos e Espírito Santo. Nestas bacias é reconhecida a ocorrência de rochas vulcânicas toleíticas com evidentes vínculos composicionais e geocronológicos aos basaltos da Formação Serra Geral (Almeida 1976).

Chang et al. (1992) apresentam um modelo de evolução tectônica e estratigráfica do denominado Sistema de Rifts do Leste do Brasil. De acordo com os autores, o preenchimento vulcânico e sedimentar das bacias continentais pode ser dividido em 4 megassequencias (continental, transicional, plataformal e marinha) vinculadas à duas fases de subsidência principais: rift e pós-rift. Segundo o modelo, o magmatismo basáltico encontrado nas bacias de Pelotas, Santos, Campos e Espírito Santo estariam vinculados a megassequencia continental, durante a fase rift destas bacias, com pico magmático entre 130-120 Ma. 
Uma série de trabalhos realizados ao longo das décadas de 1980 e 1990 levantou a possibilidade de uma correlação espacial, temporal e genética entre o magmatismo das bacias da margem continental brasileira com o magmatismo observado nas áreas emersas adjacentes (e. g. Chang et al. 1988, Chang et al. 1992, Dias et al. 1990, Macedo 1990, Fontana 1987, Almeida et al. 1996), em especial a Formação Serra Geral na América do Sul e sua contraparte em continente africano com os derrames de Etendeka (Bellieni et al. 1984).

Antes disso, baseando-se apenas em datações radiométricas ${ }^{40} \mathrm{~K} /{ }^{40} \mathrm{Ar}$ e na similaridade geoquímica, Amaral et al. (1966), já tinha considerado em seu trabalho a possível correlação das rochas vulcânicas basálticas das bacias marginais com os derrames da Formação Serra Geral.

A grande dificuldade de correlação entre o magmatismo observado nas bacias marginais com o magmatismo das áreas emersas, em especial com a Formação Serra Geral, deve-se principalmente às difíceis condições de amostragem e qualidade das amostras obtidas, unicamente a partir de perfurações para a pesquisa de hidrocarbonetos realizadas pela PETROBRAS.

Datações radiométricas de rochas vulcânicas das bacias marginais são pouco divulgadas e/ou pouco confiáveis, devido principalmente ao estado físico e natureza das amostras. Apesar disso, as poucas idades disponíveis foram compiladas e sumarizadas nos trabalhos de Mizusaki et al. (1998, 2002).

Uma síntese dos conhecimentos acumulados em 54 anos de exploração das bacias sedimentares brasileiras, em especial as bacias da margem continental, foi apresentada por Milani et al. (2007) no Boletim de Geociências da Petrobras. Esta publicação reúne a visão da PETROBRAS sobre os principais aspectos estratigráficos das bacias sedimentares brasileiras, apoiados pelo enorme acervo de informações geocronológicas (datações radiométricas e paleontológicas), sedimentológicas e bioestratigráficas obtidos a partir de dados de poços e afloramentos.

De acordo com a carta estratigráfica da Bacia de Pelotas (Bueno et al. 2007), as rochas vulcânicas de afinidade básica a intermediária descritas na bacia estão distribuídas em três unidades litoestratigráficas: formações Serra Geral, Imbituba e Curumim. Dias et al. (1994) consideram as formações Serra Geral e Imbituba 
cogenéticas. Bueno et al (2007), apoiados em datações radiométricas ${ }^{40} \mathrm{Ar} /{ }^{39} \mathrm{Ar}$ obtidas por Lobo (2007), sugerem que estas unidades estejam em parte separadas no tempo por uma discordância, e posicionam a Formação Imbituba no intervalo 130-118 Ma, enquanto para a Formação Serra Geral, os autores consideram um intervalo de idade compreendido entre 137-127 Ma. A Formação Curumim, por sua vez, seria formada por basaltos, andesitos e traquiandesitos, de idades $\left({ }^{40} \mathrm{Ar} /{ }^{39} \mathrm{Ar}\right)$ da ordem de $113 \mathrm{Ma}$ (Dias et al. 1994).

Vários autores interpretaram esses derrames como prováveis Seaward-dipping reflectors (refletores mergulhantes para o mar) intercalados a rochas sedimentares siliciclásticas (Lohmann et al. 1995, Almeida et al. 1996, Bueno et al. 2007). Idades radiométricas ${ }^{40} \mathrm{~K} /{ }^{40} \mathrm{Ar}$ em rochas basálticas atravessadas pelo poço 1-RSS-3 indicam valores ao redor de $124 \pm 8,6 \mathrm{Ma}$ (Dias et al. 1994). Na porção norte da bacia, nos domínios do Alto Estrutural de Florianópolis, ocorre expressivo volume de rochas basálticas com espessamento dos derrames no sentido do continente (Almeida et al. 1996). Apesar de não existirem idades radiométricas disponíveis para essas rochas, as características composicionais e petrográficas sugerem uma correlação com a Formação Serra Geral, como descrito em Almeida et al. (1996).

$\mathrm{Na}$ Bacia de Santos, Moreira et al. (2007) identificaram três eventos de magmatismo básico pré-albianos. Os dois primeiros representam basaltos reunidos sob a denominação de Formação Camboriú, posicionada no intervalo 137-127 Ma. O terceiro evento representa basaltos intercalados na base da Formação Barra Velha do Grupo Guaratiba e apresentaram idade ${ }^{40} \mathrm{Ar} /{ }^{39} \mathrm{Ar}$ da ordem de $117 \mathrm{Ma}$.

A Bacia de Campos, por sua vez, apresenta em sua coluna estratigráfica uma série de episódios vulcânicos no intervalo Eocretaceo-Eoceno (130-35 Ma). O mais antigo é representado pelos basaltos da Formação Cabiúnas (137-130 Ma) se estende até a Bacia do Espírito Santo (França et al. 2007). Winter et al. (2007) consideraram a Formação Cabiúnas cronocorrelata à Formação Serra Geral da Bacia do Paraná. Segundo estes autores, a Formação Cabiúnas é constituída por basaltos e diabásios subalcalinos, extrudidos em ambientes subáereos e subaquáticos, intercalados com siltitos, arenitos e conglomerados intertraps. Na Bacia do Espírito Santo, França et al (2007) posicionam a Formação Cabiúnas no intervalo 136-118 Ma baseando-se em datações ${ }^{40} \mathrm{~K} /{ }^{40} \mathrm{Ar}$. 


\section{3 - Avaliação das informações geocronológicas}

Encontram-se disponíveis na literatura uma grande quantidade de dados geocronológicos referentes a idades radiométricas das rochas vulcânicas e subvulcânicas relacionadas à Formação Serra Geral. A maior parte dos dados representa datações realizadas nas décadas de 1960 e 1970 pela sistemática ${ }^{40} \mathrm{~K} /{ }^{40} \mathrm{Ar}$ no então recém implantado Laboratório de Geocronologia do Departamento de Geologia da Faculdade de Filosofia Letras e Ciências da Universidade de São Paulo. Grande parte das idades K-Ar compiladas aqui foram inicialmente obtidas por Amaral et al. (1966), Fodor et al. (1984), Fodor \& Veter (1984) e Misuzaki et al. (1998, 2002) e reunidas por Rocha-Campos et al. (1988).

Determinações radiométricas ${ }^{40} \mathrm{~K} /{ }^{40} \mathrm{Ar}$ representam idades de resfriamento, indicam a época em que a temperatura do sistema isotópico ${ }^{40} \mathrm{~K} /{ }^{40} \mathrm{Ar}$ atinge a temperatura crítica para a retenção de argônio. Isso ocorre para o caso de muitas espécies minerais, onde a temperatura de fechamento varia em cada uma delas (Quadro 02). No entanto, o significado de uma datação ${ }^{40} \mathrm{~K} /{ }^{40} \mathrm{Ar}$ é similar em qualquer caso, representando o tempo decorrido desde que o mineral analisado iniciou a retenção de argônio, ou seja, o resfriamento do ambiente para valores abaixo da temperatura crítica (Dickin 1997). Assim, idades ${ }^{40} \mathrm{~K} /{ }^{40} \mathrm{Ar}$ são sempre consideradas idades mínimas relativas aos episódios de formação dos minerais e rochas, podendo representar idades mais jovens que as idades de cristalização dos magmas. No entanto, rochas cristalizadas em ambientes rasos e com resfriamento relativamente rápido como no caso de rochas vulcânicas e subvulcânicas, tais idades representam uma aproximação adequada das idades de cristalização.

O método ${ }^{40} \mathrm{~K} /{ }^{40} \mathrm{Ar}$ pode ser utilizado para datar tantos espécimes minerais individuais, como para rocha total. Neste caso, a precisão do método é menor devido à falta de controle da fase mineral datada. 
Quadro 2 - Sumário das temperaturas de fechamento calculadas de porcentagens de difusão de $\mathrm{Ar}$ em diferentes minerais a taxas de resfriamento de $5^{\circ} \mathrm{C} / \mathrm{Ma}$.

\begin{tabular}{|c|c|c|c|c|}
\hline \multirow{2}{*}{ Mineral } & \multicolumn{2}{|c|}{\begin{tabular}{|c|}
$\begin{array}{c}\text { Temperatura de } \\
\text { fechamento }\end{array}$ \\
\end{tabular}} & \multirow{2}{*}{$\begin{array}{c}\text { Tamanho do Grão } \\
\mathrm{mm}\end{array}$} & \multirow{2}{*}{ Referência } \\
\hline & ${ }^{\circ} \mathbf{C}$ & \pm & & \\
\hline Hornblenda & 490 & - & 80 & Harrison(1981) \\
\hline Hornblenda & 685 & $53 \mathrm{a}$ & 210 a 840 & Berger \& York(1981) \\
\hline Biotita & 373 & $21 \mathrm{a}$ & 500 a 1410 & Berger \& York(1981) \\
\hline Feldspato Alcalino & 230 & $18 \mathrm{~b}$ & 125 a 840 & Berger \& York(1981) \\
\hline Plagioclásio & 176 & $54 a, b$ & 125 a 210 & Berger \& York(1981) \\
\hline Microclineo & 132 & 13 & 125 a 250 & Harrison \& Mcdougall(1981) \\
\hline
\end{tabular}

${ }^{a}$ Média de algumas determinações julgadas válidas pelo autores

${ }^{\mathrm{b}_{\mathrm{b}}}$ Taxa de resfriamento assumida como $0,5^{\circ} \mathrm{C} / \mathrm{Ma}$

Fonte:Faure,G. Principles of Isotope Geology 2nd ed.chap.7,pp.108-111

Considerando as premissas interpretativas do método ${ }^{40} \mathrm{~K} /{ }^{40} \mathrm{Ar}$, é possível a utilização desses dados para determinar o intervalo de variação das idades existentes para o magmatismo Serra Geral, bem como as rochas vulcânicas presentes nas bacias marginais.

A partir da década de 1990, com o aperfeiçoamento da sistemática radiométrica ${ }^{40} \mathrm{Ar} /{ }^{39} \mathrm{Ar}$ foram intensificados os estudos geocronológicos sobre a Formação Serra Geral, na tentativa de estabelecer o intervalo de tempo compreendido durante a extrusão de todo o volume de lavas. A sistemática ${ }^{40} \mathrm{Ar} /{ }^{39} \mathrm{Ar}$ é considerada mais precisa em relação à sistemática ${ }^{40} \mathrm{~K} /{ }^{40} \mathrm{Ar}$ em vários aspectos: $1^{\circ}$ ) a sistemática ${ }^{40} \mathrm{Ar} /{ }^{39} \mathrm{Ar}$ é relativamente menos complexa, uma vez que medir isótopos de um mesmo elemento é muito mais simples do que medir isótopos de diferentes elementos; $2^{\circ}$ ) o método de medição via aquecimento em passos (step heatting) permite avaliar a origem do Ar medido, se radiogênico ou atmosférico, auxiliando na detecção de possíveis contaminações (Faure 1986). Apesar da grande difusão de idades ${ }^{39} \mathrm{Ar} /{ }^{40} \mathrm{Ar}$ disponíveis na literatura e utilizadas como embasamento para modelos de evolução de províncias basálticas e da crosta oceânica, Baksi (2005) chama atenção para o fato de muitas das idades não apresentarem significado geológico devido a falta de consistência analítica e estatística de seus resultados. 
Renne et al. (1992) e Hawkeswoth et al. (1992), a partir de datações ${ }^{40} \mathrm{Ar} /{ }^{39} \mathrm{Ar}$ pela técnica incremental laser heating, obtiveram idades de $133 \pm 1 \mathrm{Ma}$ e duração de menos de 1 milhão de anos para todo o vulcanismo vinculado à Formação Serra Geral.

Trabalhos posteriores realizados por Turner et al. (1994) e Stewart et al. (1996) a partir de determinações radiométricas ${ }^{40} \mathrm{Ar} /{ }^{39} \mathrm{Ar}$ combinando as técnicas de laser spot e stteped heating em rochas vulcânicas ácidas e básicas de diferentes regiões da Província Magmática Paraná obtiveram idades isocrônicas ${ }^{39} \mathrm{Ar} /{ }^{40} \mathrm{Ar}$ versus ${ }^{36} \mathrm{Ar} /{ }^{40} \mathrm{Ar}$ entre 138 e $127 \mathrm{Ma}$, sugestivas de um intervalo de pelo menos 11 milhões de anos para a extrusão de toda pilha de rochas vulcânicas. Em trabalho recém publicado, Thiede \& Vasconcelos (2010) acreditam haver comprovado a hipótese da rápida extrusão do magmatismo Serra Geral, através da obtenção de idades ${ }^{40} \mathrm{Ar} /{ }^{39} \mathrm{Ar}$ pela técnica de incremental laser heating em amostras anteriormente utilizadas por Turner et al. (1994) e Stewart et al. (1996) e indicadas por estes como as amostras com idade mais jovem e mais antiga, perfazendo uma diferença de 11 milhões de anos. Os autores obtiveram

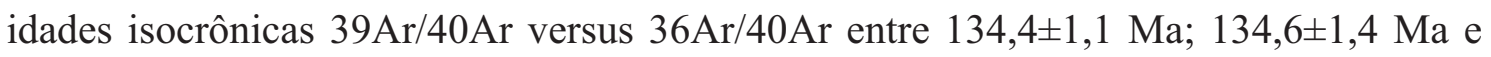
$134,8 \pm 0,8$ Ma. A partir dessas idades atribuem o início do magmatismo por volta de $134,7 \pm 1 \mathrm{Ma}$ com duração menor que 1 milhão de anos e acreditam terem confirmado a hipótese de Renne et al. (1992), onde toda a pilha de lavas teria extravasado em um curto intervalo de apenas 1 milhão de anos.

Apesar da quantidade e qualidade dos resultados analíticos apresentados por Thiede \& Vasconcelos (2010), a amostragem realizada pelos autores peca pela falta de controle estratigráfico das amostras datadas. Em derrames vulcânicos como o da Formação Serra Geral, espera-se a existência de um padrão decrescente de idades rumo ao topo da sucessão vulcânica, conforme a ocorrência de episódios de extravasamento e empilhamento de lavas. Seguindo este critério, Onstott et al. (1993 apud Milani 1997) apresentaram os resultados de datações ${ }^{39} \mathrm{Ar} /{ }^{40} \mathrm{Ar}$ realizadas a partir de uma seção de rochas ígneas vulcânicas atravessadas pelo poço Alto Piquiri da PETROBRAS, na porção central da Bacia do Paraná. Os resultados radiométricos mostram idades mais jovens no sentido do topo da sucessão vulcânica $(136,6 \pm 1,5$ a $1038 \mathrm{~m}$, e $130,8 \pm 6,0$ a $140 \mathrm{~m}$ de profundidade). No entanto, se considerarmos os erros dessas idades essa afirmação não se sustenta. 
Dados paleomagnéticos apresentados por Ernesto et al. (1990, 1999) e Renne et al. (1992, 1996), obtidos em sucessões vulcânicas consideradas como representativas de toda coluna estratigráfica da Formação Serra Geral, levaram os autores a proporem a existência de no máximo 4 reversões de polaridade magnética que, segundo Thiede \& Vasconcelos (2010), estariam de acordo com a ideia proposta por Gradstein et al. (2004) de que tais mudanças de polaridade magnética ocorrem aproximadamente em intervalos de 400 mil anos, corroborando, segundo os autores, a hipótese de rápida extrusão das lavas da Formação Serra Geral em um intervalo mínimo de 1,2 milhões de anos.

No entanto, datações U-Pb em zircão obtidas por SHRIMP em diferentes litotipos apresentadas por Pinto et al. (2010) mostraram valores mínimo e máximo entre $134,4 \pm 1,1$ e $135,6 \pm 1,8 \mathrm{Ma}$, respectivamente. A idade mais nova encontrada pelos autores representa um basalto situado no vale do Rio Uruguai em Santa Catarina, enquanto a idade mais antiga foi obtida em quartzo latito nos domínios do Lineamento do Rio Piquiri. Cabe observar que a idade mais antiga encontra-se em um nível considerado estratigraficamente acima do basalto onde foi obtida a idade mais jovem.

Freitas (2009) e Janasi et al. (2010) apresentaram idades U-Pb TIMS em cristais de zircão e badeleíta de rochas vulcânicas ácidas associadas à Formação Serra Geral com idade isocrônica ${ }^{206} \mathrm{~Pb} /{ }^{238} \mathrm{U}$ versus ${ }^{207} \mathrm{~Pb} /{ }^{235} \mathrm{U}$ de $134,4 \pm 0,9$ Ma. De acordo com os autores, a amostra datada representa um dacito extravasado direto sobre o embasamento pré-cambriano e recoberto por basaltos toleíticos de alto $\mathrm{TiO}_{2}$.

Em outro trabalho, Florisbal et al. (2010) apresentou uma idade U-Pb TIMS em cristais de zircão e baddeleíta do dique de diabásio de aproximadamente 50 metros de

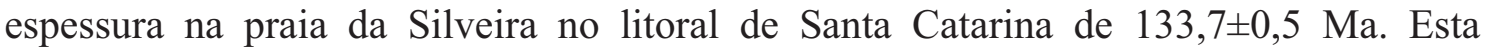
datação representa a única datação $\mathrm{U}-\mathrm{Pb}$ de diques associados ao magmatismo Serra Geral.

Assim, idades K-Ar representam idades de resfriamento, devendo ser tratadas como idades mínimas. As idades Ar-Ar, embora mais precisas, também representam idades de resfriamento. Já datações geocronológicas $\mathrm{U}-\mathrm{Pb}$, em cristais de zircão ou baddeleyíta representam geocronômetros excepcionais e permitem determinar com precisão e exatidão idades de cristalização magmática (Krogh et al. 1984). 


\subsubsection{Discussão sobre os dados geocronológicos disponíveis na bibliografia}

$\mathrm{Na}$ tentativa de delimitar um intervalo mais preciso para o magmatismo Serra Geral, nesta dissertação foram realizados estudos estatísticos baseados num total de 367 determinações geocronológicas das seguintes sistemáticas isotópicas: K-Ar (241 idades), Ar-Ar (120 idades) e U-Pb (06 idades) distribuídas ao longo da Província Magmática Paraná (Figura 16). Junto com esses dados estão computados 17 datações radiométricas da Província Etendeka extraídos dos trabalhos de Renne et al. (1996) e Kirstein et al. (2001). Os dados geocronológicos foram separados considerando a sistemática isotópica, fase mineral datada, litotipo e forma de jazimento. A partir desses dados foram calculados os parâmetros básicos da estatística descritiva convencional (média, desvio padrão, moda mediana etc.) para cada sistemática isotópica considerada. A fundamentação estatística utilizada foi baseada em Triola (2005).

Com base no resumo estatístico apresentado no Quadro 03, podemos observar que a média geral dos dados geocronológicos referentes às rochas vulcânicas da Província Magmática Paraná-Etendeka, foi de 129,13 Ma com desvio padrão de 11,59 Ma, e mediana de 130,80 Ma. A pequena diferença observada entre a média e a mediana indica uma baixa influência de valores extremos na média, confirmando esta como uma medida de boa precisão.

Quadro 03 - Resumo estatístico dos dados geocronológicos do magmatismo Serra Geral.

\begin{tabular}{|l|r|r|r|r|}
\cline { 2 - 5 } \multicolumn{1}{c|}{} & \multicolumn{1}{c|}{ Ar-Ar } & \multicolumn{1}{c|}{ K-Ar } & \multicolumn{1}{c|}{ U-Pb } & \multicolumn{1}{c|}{ Geral } \\
\hline Média & 133.22 & 126.96 & 134.57 & 129.13 \\
\hline Desvio Padrão & 4.47 & 13.46 & 0.63 & 11.59 \\
\hline Moda & 132.10 & 127.10 & N.D. & 134.10 \\
\hline Mediana & 133.58 & 127.20 & 134.50 & 130.80 \\
\hline Variância & 19.99 & 181.05 & 0.39 & 134.31 \\
\hline Mínimo & 120.50 & 79.10 & 133.70 & 79.10 \\
\hline Máximo & 148.61 & 215.30 & 135.60 & 215.30 \\
\hline Amostras & 120.00 & 241.00 & 6.00 & 367.00 \\
\hline Nível de confiança (95.0\%) & 0.81 & 1.71 & 0.66 & 1.19 \\
\hline
\end{tabular}




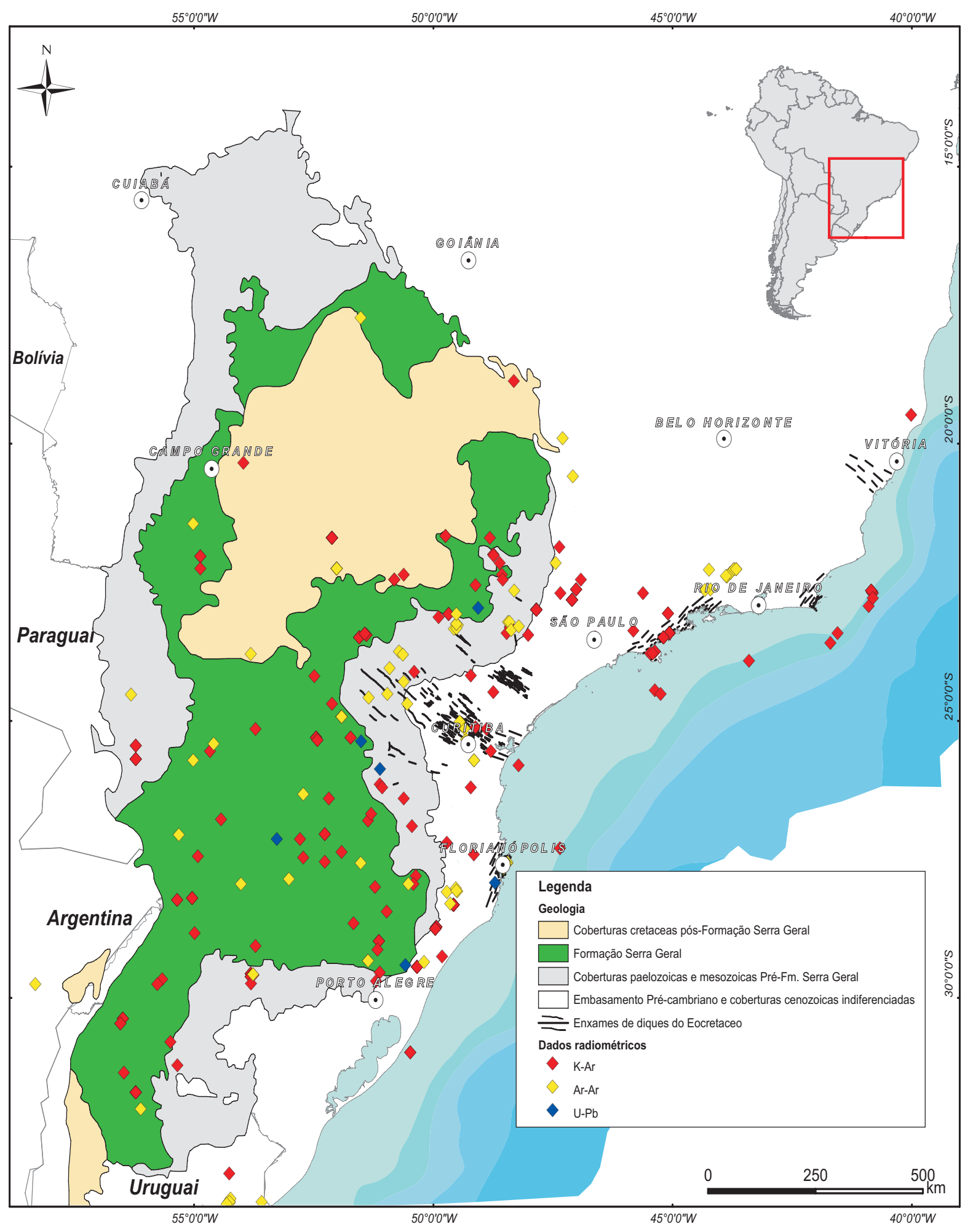

Figura 16 - Distribuição espacial das datações radiométricas disponíveis para a Província Basáltica Paraná e rochas correlatas nas bacias da margem continental. 
No entanto, estes valores servem apenas para situar uma idade mínima para o evento, uma vez que estão computados dados de sistemáticas radiométricas de significados geológicos distintos.

Mesmo com a maior dispersão relativa dos dados e do erro mais elevado, a

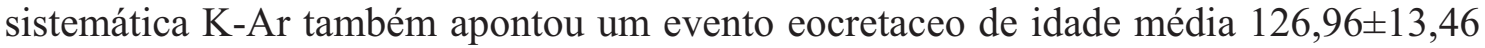
Ma. Este valor, pode ser considerado bastante preciso, considerando que dos 241 dados analisados, 157 são de datações em rocha total, sempre menos precisas em seu significado (Faure 1986).

Apesar disso, se consideramos as idades K-Ar para definir o intervalo do magmatismo, este estaria situado entre 215,1-79,1 Ma, totalizando um intervalo de 136 milhões de anos, desde o Triássico Superior até o Neocretaceo, incompatível com os conhecimentos geológicos atuais sobre a evolução da Bacia do Paraná e do Magmatismo Serra Geral. Assim, não julgamos aconselhável o uso destas idades, exceto os valores em torno da média, que servem apenas para situar o magmatismo no Eocretaceo, concordante com as sistemáticas abaixo discutidas.

Os dados Ar-Ar são mais precisos, com menor dispersão relativa. A média de idades obtida é de 133,22 $\pm 4,47 \mathrm{Ma}$, com desvio padrão de 4,47 Ma. Se definirmos o intervalo do magmatismo Serra Geral com base apenas nos dados Ar-Ar, este teria idade máxima de 148,6 Ma e mínima de 120,5 Ma, indicando um intervalo de cerca de 28 milhões de anos. No entanto, ao contrário dos dados K-Ar, esse intervalo de idades não contraria os conhecimentos geológicos da Bacia do Paraná e do Magmatismo Serra Geral.

A idade de cristalização das rochas que marcam este evento, possivelmente pode ser melhor definida pela sistemática isotópica $\mathrm{U}-\mathrm{Pb}$, embora apenas seis idades estejam disponíveis na bibliografia. Os dados U-Pb indicam uma idade média de 134,57 Ma, com desvio padrão de 0,63 Ma. A idade média dos dados U-Pb indicam idade de

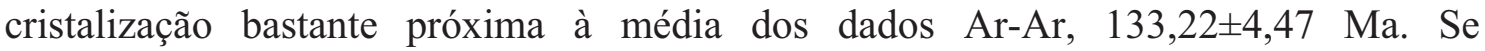
consideramos o intervalo do magmatismo apenas com base nos dados $\mathrm{U}-\mathrm{Pb}$, este está situado entre 135,6 e 133,7 Ma, totalizando um intervalo em torno de 2 milhões de anos.

Quando comparamos as idades do magmatismo extrusivo e intrusivo, observamos que diques e soleiras apresentam idade média superior as dos derrames em 
cerca de 3 a 4 milhões de anos (Quadro 04). No entanto, se considerarmos teoricamente que diques alimentadores e derrames são contemporâneos, esta diferença reflete antes uma evolução termal e intempérica distinta para as duas forma de ocorrência ígneas. Então, parece mais adequado avaliar criticamente estas medidas tentando entender seu significado antes de assumir uma postura categórica e definitiva.

Quadro 04 - Resumo estatístico dos dados geocronológicos do magmatismo extrusivo e intrusivo da Formação Serra Geral.

\begin{tabular}{|l|r|r|}
\cline { 2 - 3 } \multicolumn{1}{c|}{} & \multicolumn{1}{c|}{ Magmatismo Extrusivo } & Magmatismo Intrusivo \\
\hline Média & 127.88 & 131.38 \\
\hline Desvio Padrão & 12.81 & 8.57 \\
\hline Moda & 134.10 & 132.10 \\
\hline Mediana & 129.82 & 131.80 \\
\hline Variância & 164.16 & 73.44 \\
\hline Mínimo & 79.10 & 108.90 \\
\hline Máximo & 215.30 & 164.30 \\
\hline Amostras & 236.00 & 131.00 \\
\hline Nível de confiança (95.0\%) & 1.64 & 1.48 \\
\hline
\end{tabular}

No caso dos enxames de diques estudados, o número de datações radiométricas é bastante reduzido se considerarmos toda a extensão de ocorrência desses enxames. A análise estatística dos dados radiométricos existentes (Quadro 05) indica uma idade média maior para o enxame Serra do Mar (134,26 Ma), seguido de Ponta Grossa (133,62 Ma) e Florianópolis (128,83 Ma). No entanto, se considerarm0s os desvios padrões calculados para cada um dos enxames, podemos concluir que o alojamento desses corpos na crosta foi praticamente simultâneo. No entanto, fica claro que do ponto de vista geocronológico, esses enxames de diques ainda são mal datados.

A comparação das idades radiométricas em relação à posição geográfica das amostras datadas (latitude e longitude) indica que em grande parte da Província Magmática Paraná o magmatismo se manifestou praticamente ao mesmo tempo, por volta de $\sim 134 \mathrm{Ma}$, conforme indicado na Figura 17. 


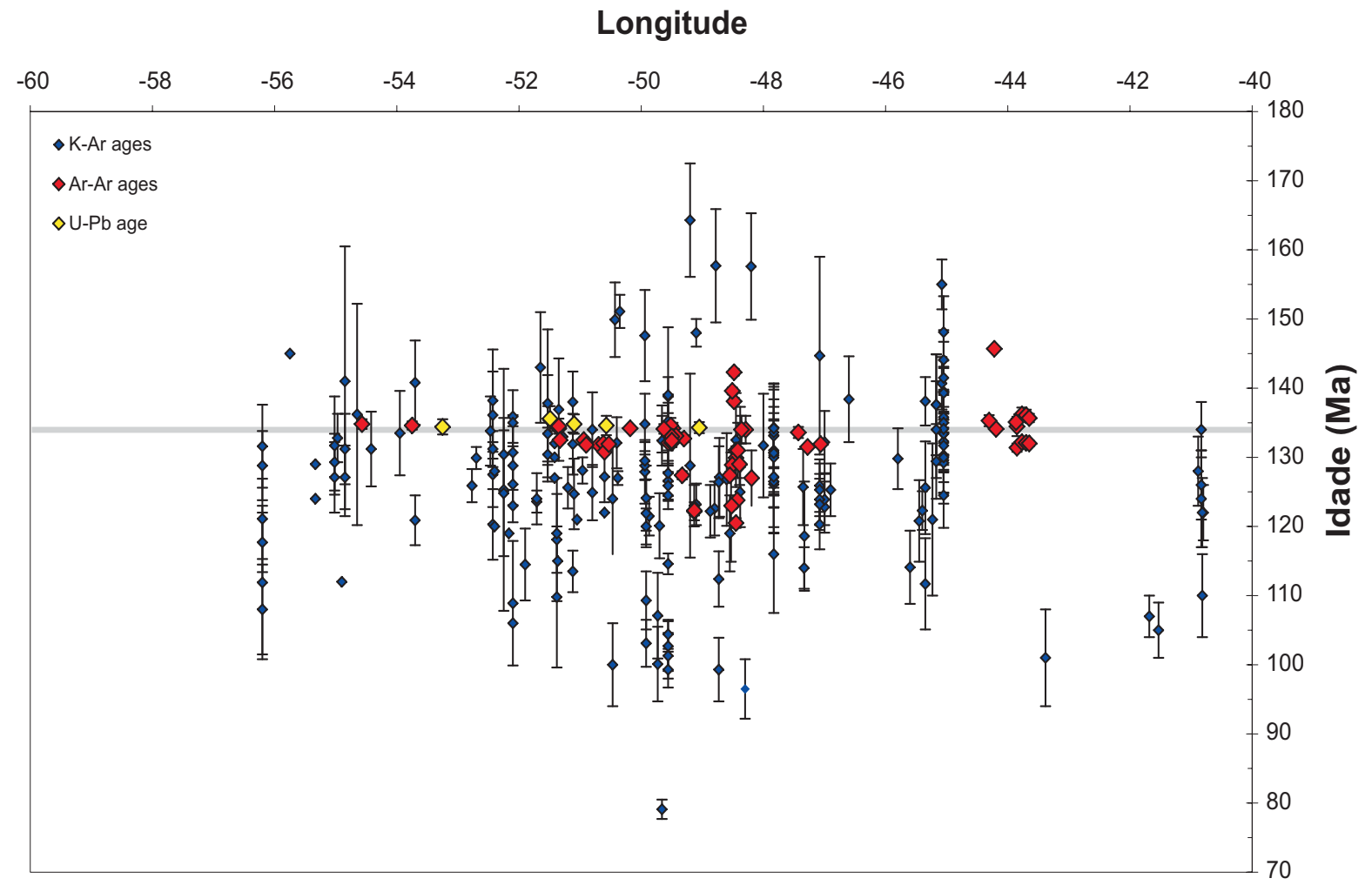

\section{Latitude}

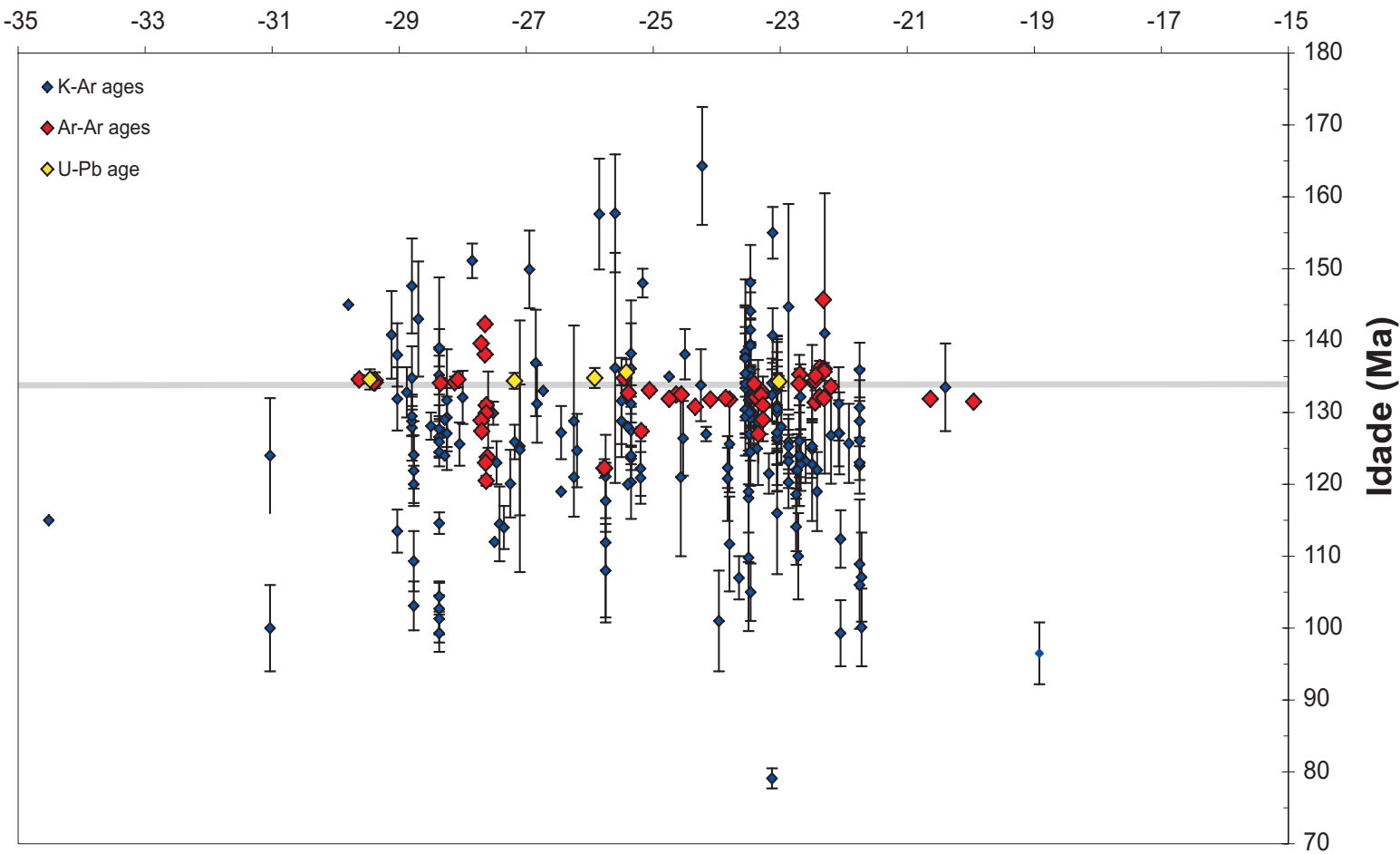

Figura 17 - Comparação da distribuição das idades radiométricas do magmatismo intrusivo e extrusivo associado a Província Magmática Paraná-Etendeka em relação a posição geográfica das amostras datadas. 
Quadro 05 - Resumo estatístico dos dados geocronológicos dos enxames de diques máficos associados à Formação Serra Geral.

\begin{tabular}{|l|r|r|r|}
\cline { 2 - 4 } \multicolumn{1}{c|}{} & \multicolumn{1}{c|}{ Florianópolis } & Ponta Grossa & \multicolumn{1}{c|}{ Serra do Mar } \\
\hline Média & 128.83 & 133.62 & 134.26 \\
\hline Desvio Padrão & 7.32 & 10.03 & 7.50 \\
\hline Moda & 123.00 & 122.20 & 134.10 \\
\hline Mediana & 128.15 & 132.10 & 134.10 \\
\hline Variância & 53.58 & 100.60 & 56.26 \\
\hline Mínimo & 120.10 & 122.20 & 111.70 \\
\hline Máximo & 142.30 & 164.30 & 155.00 \\
\hline Amostras & 14.00 & 23.00 & 42.00 \\
\hline Nível de confiança (95.0\%) & 4.23 & 4.34 & 2.34 \\
\hline
\end{tabular}

Florianópolis: (N=02 K-Ar; 11 Ar-Ar; $01 \mathrm{U}-\mathrm{Pb})$

Ponta Grossa (N=07 K-Ar; 15 Ar-Ar)

Serra do Mar (N=40 K-Ar; 12 Ar-Ar)

Assim, considerando o significado geológico destas idades, de acordo com as diferenças entre as sistemáticas isotópicas utilizadas, não se pode ainda definir um intervalo preciso de duração do magmatismo continental. No entanto, os dados existentes, principalmente $\mathrm{U}-\mathrm{Pb}$, indicam um pico de atividade ígnea por volta de $\sim 134$ Ma, como destacado nas figuras 18 e 19.

A análise conjunta destes dados confirma a tese de que o evento magmático responsável pela formação da Província Basáltica Paraná-Etendeka, bem como suas unidades correlatas nas bacias marginais brasileiras, desnecessariamente designadas com outras denominações litoestratigráficas (e.g. Formação Imbituba, Formação Camboriú e Formação Cabiúnas), é um evento de idade Eocretácea com idade mínima de $\sim 134 \mathrm{Ma}$.

As sistemáticas isotópicas mais precisas para obtenção de idades para este tipo de rochas são U-Pb (idades de cristalização) e Ar-Ar (idades de resfriamento). Uma síntese apresentando a cronoestratigrafia dos eventos magmáticos, baseadas nos dados geocronológicos existentes é apresentada na Figura 20. 
Idades K-Ar, Ar-Ar e U-Pb

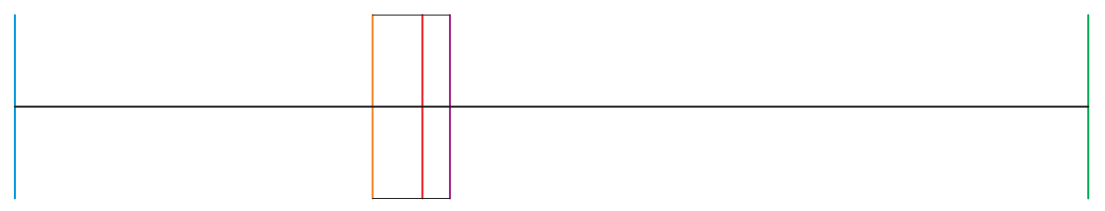

124.5 Ma $\quad$ 134.5 Ma

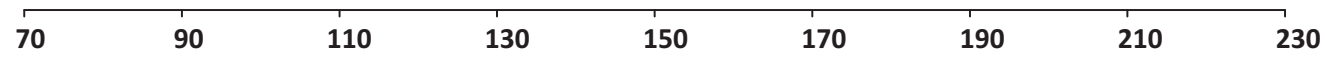

Idades K-Ar

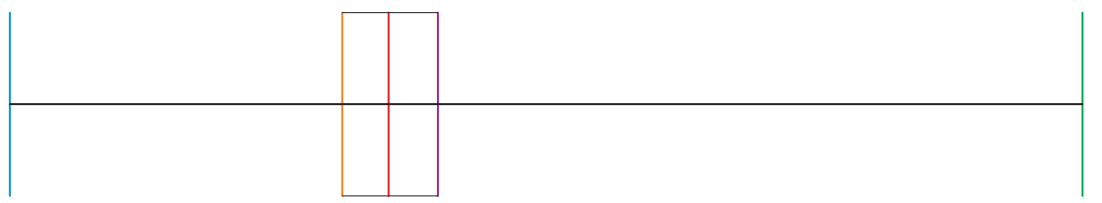

121.3 Ma $\quad 133.4 \mathrm{Ma}$

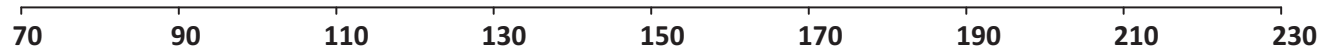

Idades Ar-Ar

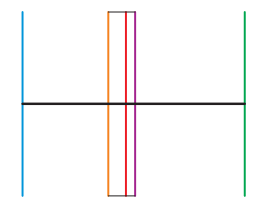

$131.3 \mathrm{Ma} \quad 134.7 \mathrm{Ma}$

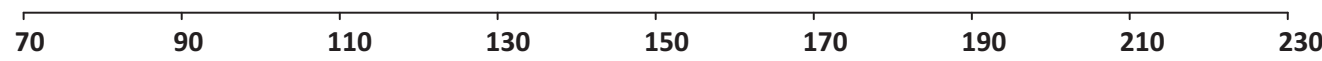

Idades U-Pb

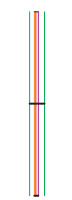

134.3 Ma 134.8 Ma

\begin{tabular}{lllllllll}
\hline 70 & 90 & 110 & 130 & 150 & 170 & 190 & 210 & 230
\end{tabular}

— Mínimo - $1^{\circ}$ quartil - Mediana - $3^{\circ}$ quartil — Máximo

Figura 18 - Comparação da distribuição das idades radiométricas por diferentes sistemáticas isotópicas de rochas ígneas vulcânicas e subvulcânicas da Província Magmática Paraná. 

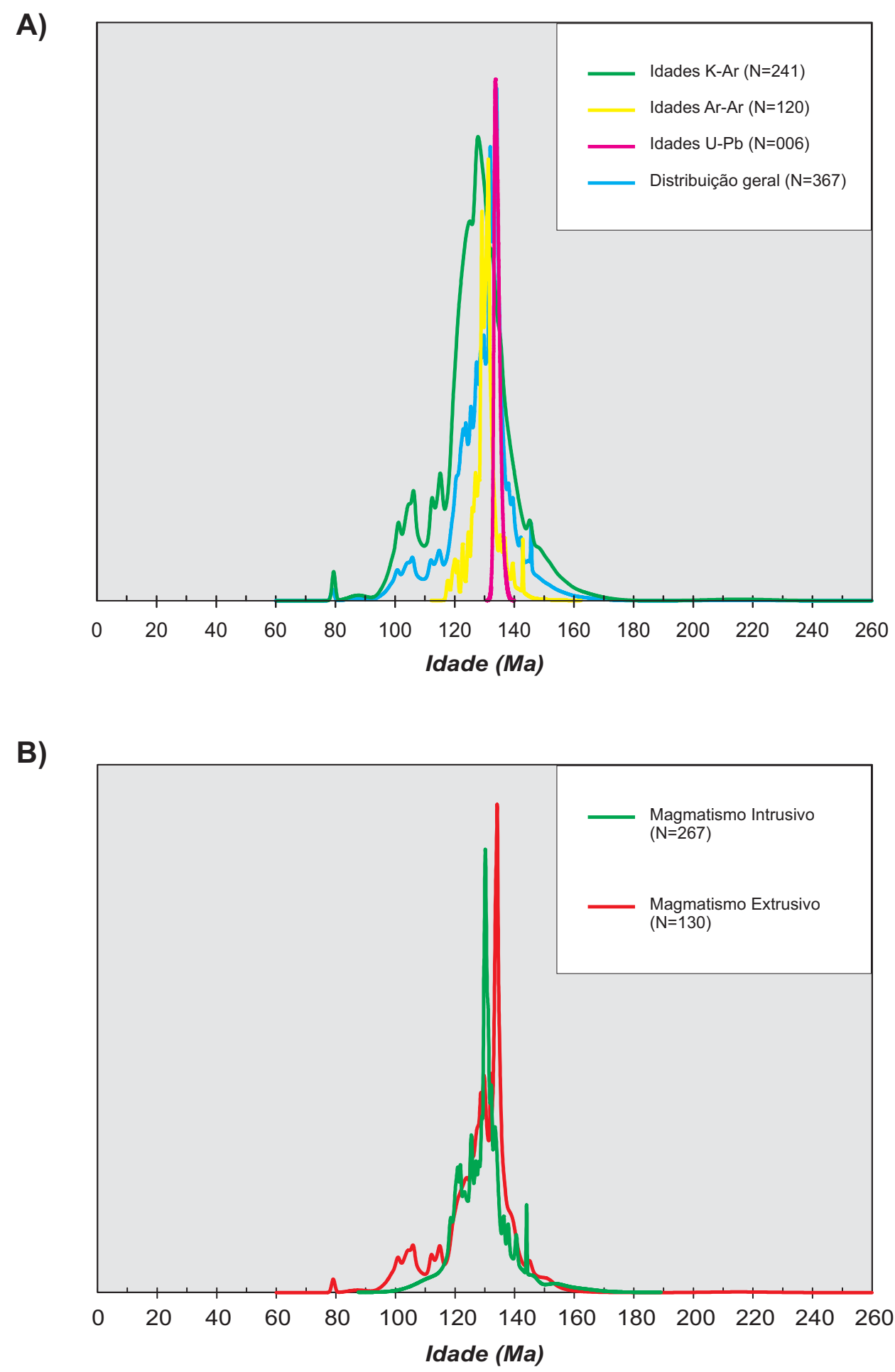

Figura 19 - A) Variação das idades radiométricas existentes para a Província Magmática Paraná e de unidades correlatas das bacias marginais brasileiras. B) Comparação da distribuição das idades radiométricas do magmatismo intrusivo e extrusivo associado a Província Magmática Paraná. 


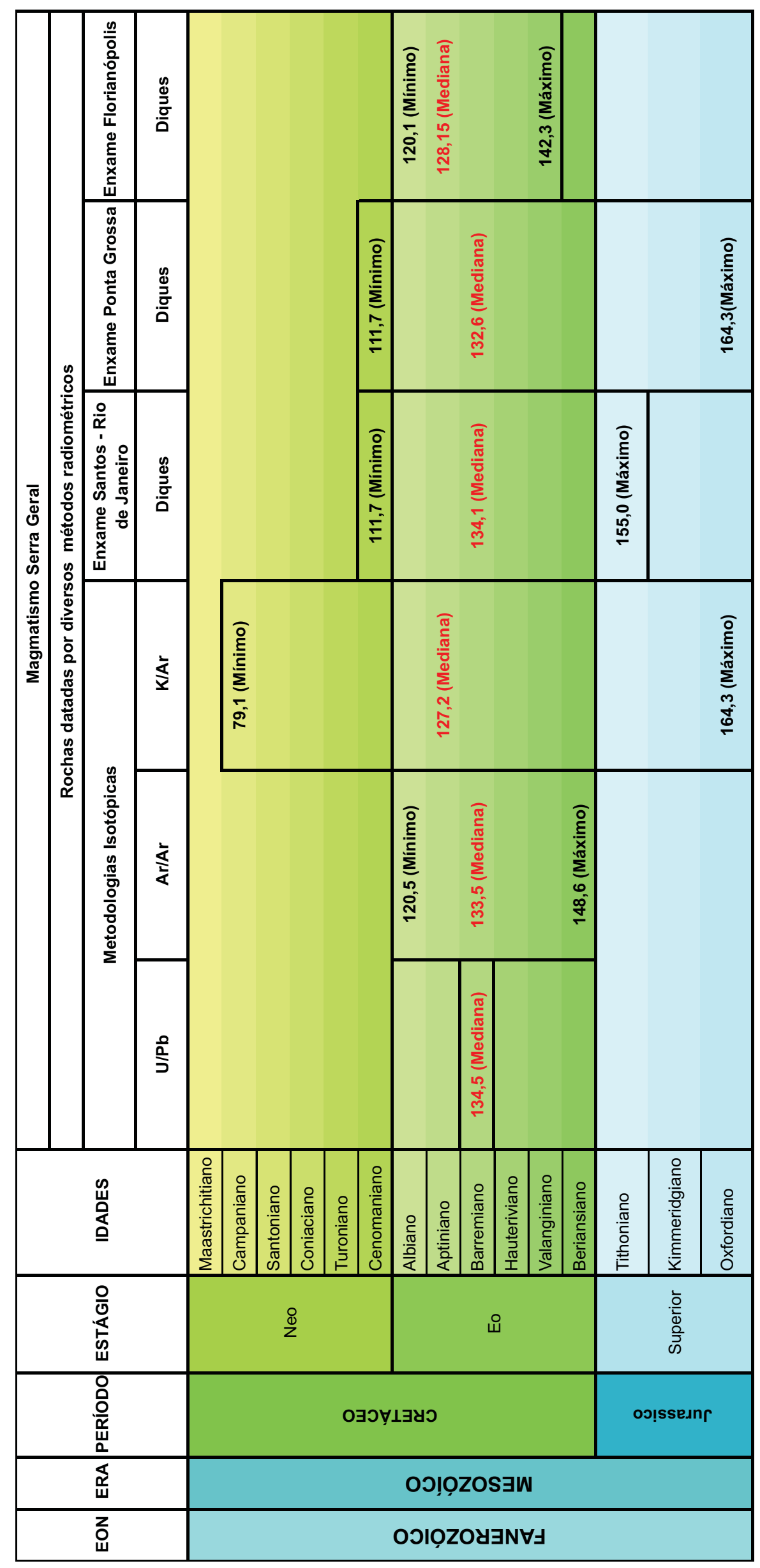




\section{CAPÍTULO V}

\section{ENXAMES DE DIQUES MÁFICOS EOCRETACEOS NO SUL- SUDESTE DO BRASIL: TEMA DE ESTUDO}

O tema de estudo da presente dissertação é a análise estrutural e tectônica dos enxames de diques eocretaceos do Sul-Sudeste brasileiro. Devido à gênese comum desses enxames de diques com os derrames basálticos da Formação Serra Geral, bem como sua relação com a fragmentação do Pangea e a abertura do Atlântico Sul, foi feita uma revisão bibliográfica sobre estes assuntos e exposta nos capítulos acima. No presente, são discutidos os três principais enxames do sul-sudeste brasileiro com acréscimo de nossos estudos realizados a partir da observação e descrição de afloramentos em trabalhos de campo em áreas selecionadas.

Grande parte do magmatismo intrusivo na forma de enxame de diques da Província Magmática Paraná-Etendeka concentra-se na região Sul-Sudeste da América do Sul (Figura 21), nos enxames de Florianópolis, Ponta Grossa e Serra do Mar (Sial et al. 1987, Coutinho 2008). Além desses segmentos, é citado na literatura a presença de diques básicos eocretaceos ao longo do Lineamento Colatina, no Espírito Santo (Novais et al. 2003). Cabe lembrar que, além dos enxames de diques máficos eocretaceos, ocorrem nos mesmos domínios diques máfico-ultramáficos de afinidades intermediária a alcalina relacionados ao magmatismo alcalino do Neocretaceo-Cenozoico (e.g. províncias alcalinas de Piratini, Serra do Mar Central e Serra do Mar Norte; vide Almeida 1983, Riccomini et al. 2005).

Uma série de trabalhos confirma a presença de profundas zonas de cisalhamento afetando o embasamento pré-magmatismo na porção Sul-Sudeste da América do Sul (e.g. Sierra Ballena, Dorsal do Canguçu, Major Gercino, Lancinha-Ribeira-CubatãoAlém Paraíba etc). Estas regiões representam zonas de fraqueza crustal e estiveram sujeitas a inúmeros episódios de reativação tectônica.

Estudos sobre os aspectos geoquímicos desses diques foram realizados ao longo desses três enxames principais (Comin-Chiramonti et al. 1983, Piccirillo et al. 1988, Pinese 1989, Hawkesworth et al. 1992, Garda 1995, Marques 2001, Dutra 2006, entre outros). Da mesma maneira que nas rochas extrusivas da Formação Serra Geral, dados 


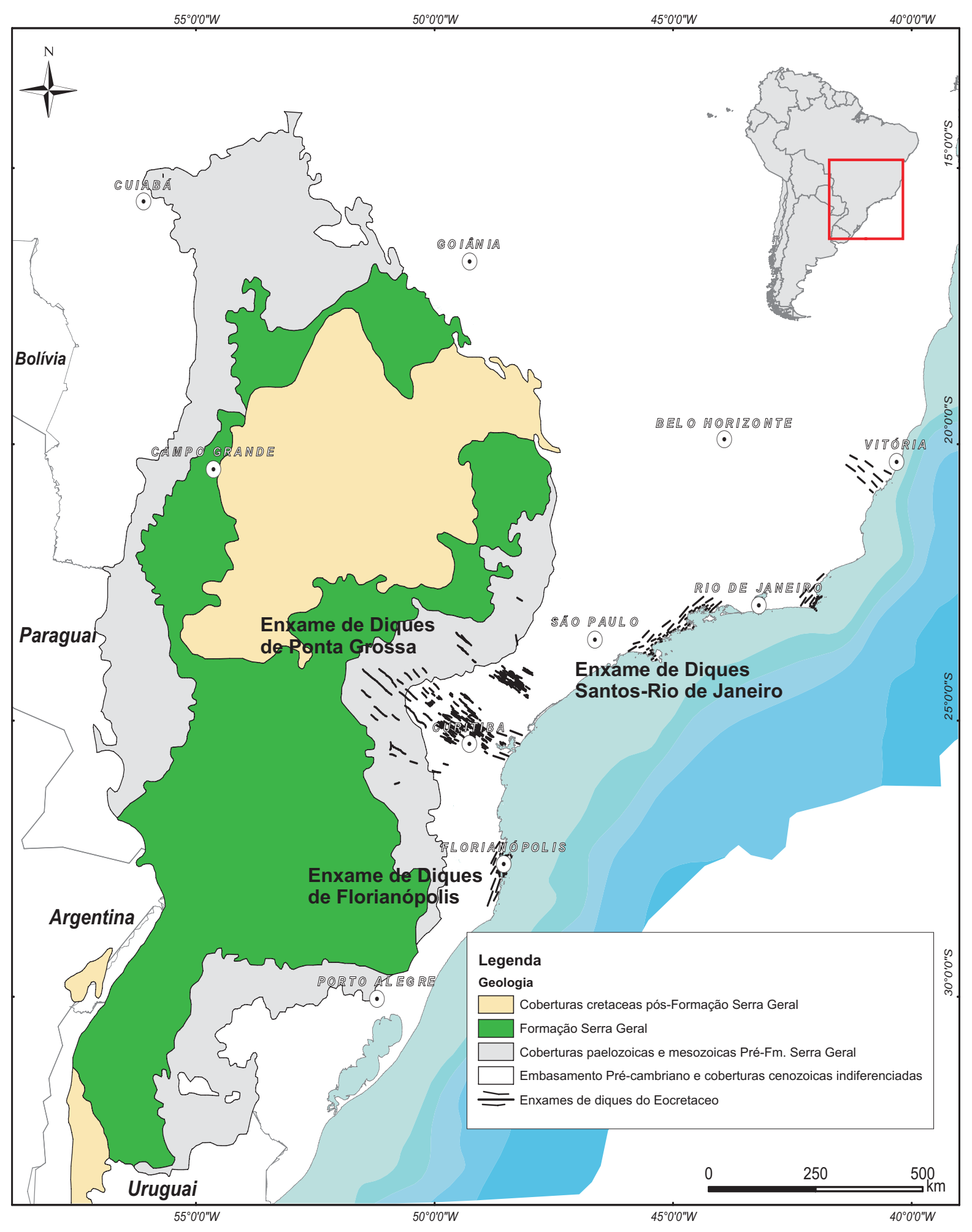

Figura 21 - Contexto geológico regional dos enxames de diques máficos eocretaceos do Sul-Sudeste do Brasil. 
geoquímicos revelaram a presença de dois grupos distintos com respeito aos teores de $\mathrm{TiO}_{2}$. Os diques presentes no enxame de Ponta Grossa podem ser classificados como basaltos, andesibasaltos, latibasalto e basalto transicional, todos de natureza toleítica, com caráter predominantemente básico, semelhantes aos derrames do tipo Pitanga e Paranapanema, com altos valores de $\mathrm{TiO}_{2}$ (Pinese 1989, Marques 2001). Os diques do enxame Santos-Rio de Janeiro, por sua vez são classificados do ponto de vista litológico como andesibasaltos, latibasaltos e latiandesitos com caráter toleíticotransicional (Garda 1995, Marques 2001). Inicialmente tais diques foram considerados como pertencentes a suítes predominantemente de alto $\mathrm{TiO}_{2}(\mathrm{Comin}-\mathrm{Chiaramonti}$ et al., 1983; Valente et al. 1998). No entanto, trabalhos posteriores demonstraram a ocorrência de diques com baixos teores de $\mathrm{TiO}_{2}$, tanto na região costeira entre Búzios e Cabo Frio, como na Região Serrana do Estado do Rio de Janeiro e Vale do Paraíba (Marques 2001, Monteiro e Valente 2003, Guedes et al. 2005, Dutra 2006). No enxame de Florianópolis, os diques são representados por andesibasaltos toleíticos, latiandesitos e subordinadamente basaltos e andesitos toleíticos, tanto de alto e baixo $\mathrm{TiO}_{2}$ (Marques 2001). Os diques presentes ao longo do Lineamento de Colatina são classificados como basaltos e basaltos andesíticos de baixo $\mathrm{TiO}_{2}$ de uma série subalcalina toleítica (Dutra et al. 2008).

Coutinho (2008) apresenta o mais amplo e completo estudo sobre os enxames de diques máficos do Sul-Sudeste da América do Sul. A partir do mapeamento e estudo petrográfico de detalhe de aproximadamente 300 diques de rochas máficas toleíticas e ultramáficas alcalinas o autor interpreta os diques toleíticos como constituinte dos braços de um sistema de junção tríplice centrado na costa do Estado do Paraná e relacionado à abertura inicial do Atlântico Sul.

Esse trabalho de Coutinho (2008) representa o guia da presente dissertação, pois esta analisa diques discutidos por este autor, além de outros próximos, pertencentes ao mesmo contexto, mas não investigados na citada publicação.

Coutinho (2008) cartografa e descreve “as características mineralógicas e petrográficas dos diques máficos que ocorrem ao longo de $650 \mathrm{~km}$ da costa sudeste brasileira, entre as cidades de São Sebastião-SP e a Ilha de Santa Catarina-SC" (pág.29). Destes diques, 98 foram estudados nesta dissertação, além de outros 12 a norte 
de São Sebastião-SP, em Paraty-RJ, e no Enxame de Diques de Florianópolis, 15 a sul da Ilha de Florianópolis, em Garopaba, Silveira, Barra de Ibiraquera e Ribanceira.

\section{1 - Enxame de Diques Serra do Mar (Santos-Rio de Janeiro)}

Dos três enxames de diques eocretaceos do sudeste do Brasil, o ramo correspondente ao Enxame de Diques Serra do Mar (Santos-Rio de Janeiro) é sem dúvida o mais estudado. Os diques são acessíveis preferencialmente na faixa litorânea dos estados de São Paulo e Rio de Janeiro, com inúmeras ocorrências na porção interiorana adjacente, confirmando a abrangência regional do evento de colocação desses corpos.

A geologia do Pré-cambriano da região costeira dos estados de São Paulo e Rio de Janeiro, de uma maneira geral, é ainda pouco conhecida. Na Carta Geológica do Brasil ao Milionésimo (CPRM 2004), tais rochas estão reunidas sob a denominação de Complexo Costeiro (Hasuy et al. 1981). Esta denominação reflete o baixo nível de conhecimento sobre tais litologias, uma vez que nesta unidade estão reunidos indiscriminadamente conjuntos de rochas com características e natureza distintas, englobando gnaisses para e orto derivados, migmatitos, granitos e charnockitos.

De acordo com o IPT (1981), o Complexo Costeiro é definido como de idade paleoproterozoica, embora envolva corpos graníticos e outros mais jovens. De acordo com o trabalho citado, abrange uma série de unidades litológicas distinguidas por diversos autores tendo recebido as mais diferentes denominações. Predominam na unidade rochas migmatíticas com estruturas variadas; granulitos em faixas e núcleos restritos, representadas por granulitos quartzo feldspáticos, kinzigitos, charnockitos e rochas granito-gnáissicas com hiperstênio, localmente migmatizadas e transpostas por uma foliação milonítica. Em algumas regiões, principalmente entre São Sebastião e Caraguatatuba, é comum a presença de corpos básicos, constituídos por metadioritos, metagabros e outros (Karniol 2000). De uma maneira geral, o Complexo Costeiro representa uma unidade de médio a alto grau metamórfico onde as relações estruturais entre os diferentes litotipos ainda não são bem compreendidas. 
No Estado do Rio de Janeiro, o Complexo Costeiro é formado por gnaisses, granitóides e migmatitos, com intercalações de rochas metassedimentares representadas por quartzitos, mármores e rochas calcissilicáticas (Hasuy \& Oliveira 1984), ocorrendo também charnockito-gnaisses e kinzigitos. Na região entre Armação dos Búzios e Cabo Frio, as rochas metamórficas ortoderivadas e paraderivadas, representadas por migmatitos, gnaisses granulíticos, anfibolitos e rochas calcissilicáticas, estão reunidas na Sequência Búzios, de Fonseca et al. (1979).

A região costeira entre São Paulo e Rio de Janeiro é afetada por uma série de zonas de cisalhamento e faixas miloníticas pré-cambrianas de direção principal NE-SW, comuns a toda porção sudeste da América do Sul. Estas estruturas apresentam uma longa e complexa história geológica possivelmente iniciada no Paleoproterozoico, com períodos de reativação tectônica durante a Orogenia Brasiliana (Neoproterozoico) e eventos posteriores do Ediacarano-Cambriano, Paleozoico e Mesozoico-Cenozoico (e. g. Almeida 1967, Riccomini \& Assumpção 1999, Riccomini et al. 2004, Fragoso-Cesar 2008, Almeida et al. 2010).

O Enxame de Diques Serra do Mar ocorre distribuído ao longo do Planalto Atlântico nos domínios geomorfológicos da Serra do Mar (Almeida 1986). A feição orográfica conhecida como Serra do Mar representa um conjunto de escarpas festonadas com cerca de $1.000 \mathrm{~km}$ de extensão, desde os estados do Rio de Janeiro até Santa Catarina, onde termina o Planalto Atlântico. Almeida \& Carneiro (1998) atribuem a origem da Serra do Mar aos fenômenos tectono-magmáticos envolvidos na reativação tectônica durante o Cenozoico, especificamente a partir do Paleoceno, onde deformações causadas por flexura, frente à carga de sedimentos nas bacias marginais, levaram a reativações de estruturas do embasamento pré-cambriano, dando origem às bacias tafrogênicas do sudeste brasileiro (Sistema de Rifts da Serra do Mar sensu Almeida 1976 ou Rift Continental do Sudeste do Brasil sensu Riccomini 1989).

O sudeste da América do Sul apresenta uma história de reativações tectônicas superpostas, soerguimento e denudação. Estudos de termocronologia por traço de fissão em apatita em diferentes compartimentos topográficos do sudeste do Brasil mostram soerguimento progressivo desta porção do continente durante o Mesozoico e ativo até o recente (Gallagher et al. 1994, Hackspacher et al. 2004, Hiruma et al. 2010, FrancoMagalhães et al. 2010). 


\subsubsection{Estudos no Enxame de Diques Serra do Mar}

Neste enxame de diques foram descritos afloramentos na região litorânea entre os municípios de São Sebastião e Ilhabela, na região entre Ubatuba, Paraty e Angra dos Reis, e entre Búzios e Cabo Frio, totalizando a descrição de 98 diques. Além disso, foram compilados medidas e ocorrências de diques de diabásio dos trabalhos de Damasceno (1966), Garda (1995), Ferrari (2001), Silva \& Riccomini (2005), Tomba \& Sato (2006), Valente et al. (2005) e, fundamentalmente, Coutinho (2008). A apresentação dos estudos estruturais será feita com base em domínios onde os diques apresentam mesma associação litológica como encaixante. Assim foram separados quatro segmentos: São Sebastião-Ilhabela, Ubatuba-Paraty-Angra dos Reis e BúziosCabo Frio.

No segmento São Sebastião-Ilhabela, os diques medidos foram descritos em campo como diabásio. De modo geral, estes litotipos apresentam coloração cinza escuro a preta, textura afanítica a fanerítica fina a média, equigranular e inequigranular. A mineralogia observada em campo é formada principalmente por plagioclásio e piroxênio, com ilmenita, magnetita e pirita como opacos acessórios.

A partir da descrição detalhada de lâminas petrográficas, Coutinho (2008) caracterizou estas rochas como diabásio, diabásio pórfiro e microdiorito pórfiro. Segundo o autor, as rochas classificadas como diabásio apresentam granulação fina a média, textura intergranular a subofítica. A mineralogia essencial é formada por plagioclásio cálcico $\left(\mathrm{An}_{50-60}\right)$ e clinopiroxênio (augita-pigeonita). Como acessórios ocorrem apatita e opacos, como magnetita, ilmenita e pirita. Os litotipos classificados como diabásio pórfiro são caracterizados como rochas microporfiríticas, matriz de granulação fina, textura intergranular a intersertal. A mineralogia é constituída de plagioclásio cálcico (An50-60), clinopiroxênio (augita) e olivina. De acordo com Coutinho (2008), estas rochas apresentam certa familiaridade com rochas lamprofíricas. A presença de microdiorito pórfiro, descrita inicialmente por Garda (1995), é caracterizada por textura microporfirítica com matriz fina. Os fenocristais são formados por plagioclásio $\left(\mathrm{An}_{20-50}\right)$, augita e hiperstênio. 


\subsubsection{São Sebastião-Ilhabela}

$\mathrm{Na}$ porção entre São Sebastião e Ilhabela, os diques estudados apresentam direção predominante NE-SW. A dispersão dos dados é relativamente pequena com franco predomínio de diques entre as direções N30-60E (Figura 22A). Os mergulhos desses corpos mostram caimentos dominantemente de alto ângulo para os quadrantes NW e SE (Figura 22B). Em toda a região é comum a presença de fraturas oblíquas, ortogonais, paralelas e subparalelas aos diques (Figura 22C). A foliação milonítica regional observada nas rochas encaixantes apresenta atitude variando entre N20-70E, com mergulhos variando de baixo a alto ângulo, geralmente paralela e/ou subparalela à direção dos diques (Figura 22D).

Nesta região os diques intrudem principalmente migmatitos bandados e ortognaisses do Complexo Costeiro. Os migmatitos foram descritos em campo como rochas bandadas de granulação média a grossa com leucossoma quartzo feldspático, às vezes com granada. O melanossoma é formado por anfibólio preto a esverdeado e biotita, isorientados em bandas centimétricas $(\sim 5 \mathrm{~cm})$. Estas feições encontram-se transpostas por uma marcante foliação protomilonítica a milonítica, registrada pela forte elongação dos minerais, com direção geral N40E (Prancha I - Foto 01).

A relação temporal entre as fraturas e os diques nem sempre é clara, devido ao paralelismo das estruturas. No entanto, em alguns casos, a relação de corte entre fraturas e diques indicou a existência de fraturas anteriores à intrusão. Em uma única situação, foi observada a ocorrência de um dique de lamprófiro intrudindo paralelamente um dique de diabásio (Prancha I - Foto 02). Este fato é muito importante, uma vez que mostra a recorrência do aproveitamento de fraturas e zonas de fraqueza da crosta para a intrusão de diques.

A geometria dos diques é predominantemente retilínea e mais raramente segmentada (Prancha II - Foto 03 e Foto 04), geralmente com bordas de resfriamento. Os diques apresentam marcantes feições rúpteis caracterizadas como segmentos de diques com terminações abruptas, caracterizadas como chifres e saltos. Estas feições confirmam o estado rúptil da encaixante durante a intrusão. 

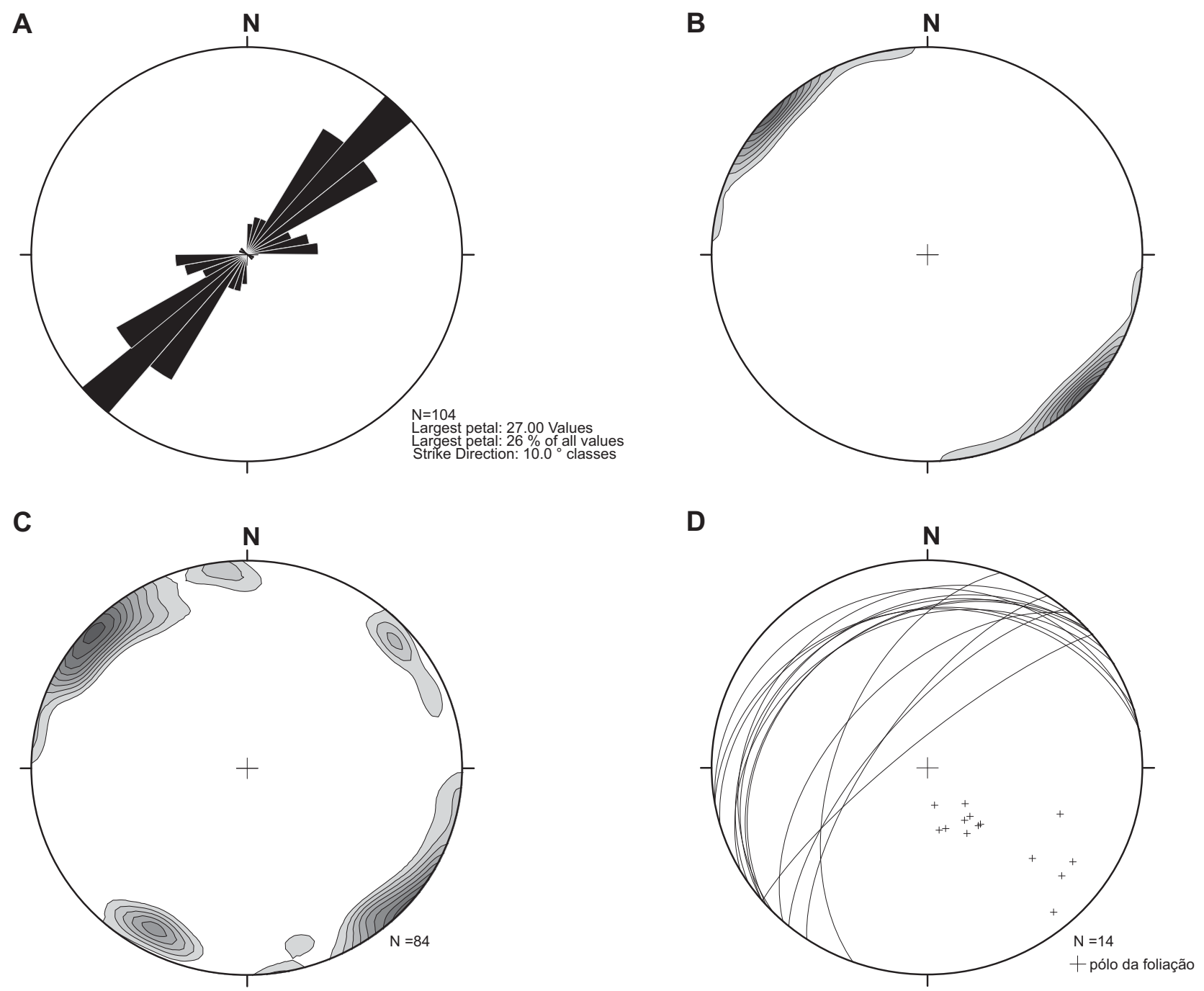

Figura 22 - A) Diagrama de rosácea representando 104 diques de diabásio entre São Sebastião e Ilhabela dados obtidos nesta dissertação e compilados dos trabalhos de Garda (1995), Silva \& Riccomini (2005) e Coutinho (2008). B) Diagrama de contornos dos diques indicando o predomínio de mergulhos subverticais. C) Diagrama de contornos de atitude de fraturas nas rochas encaixantes dos diques. D) Notar a presença de fraturas subparalelas à direção dos diques. Projeção estereográfica da atitude da foliação regional do embasamento pré-cambriano . 


\section{Prancha I}

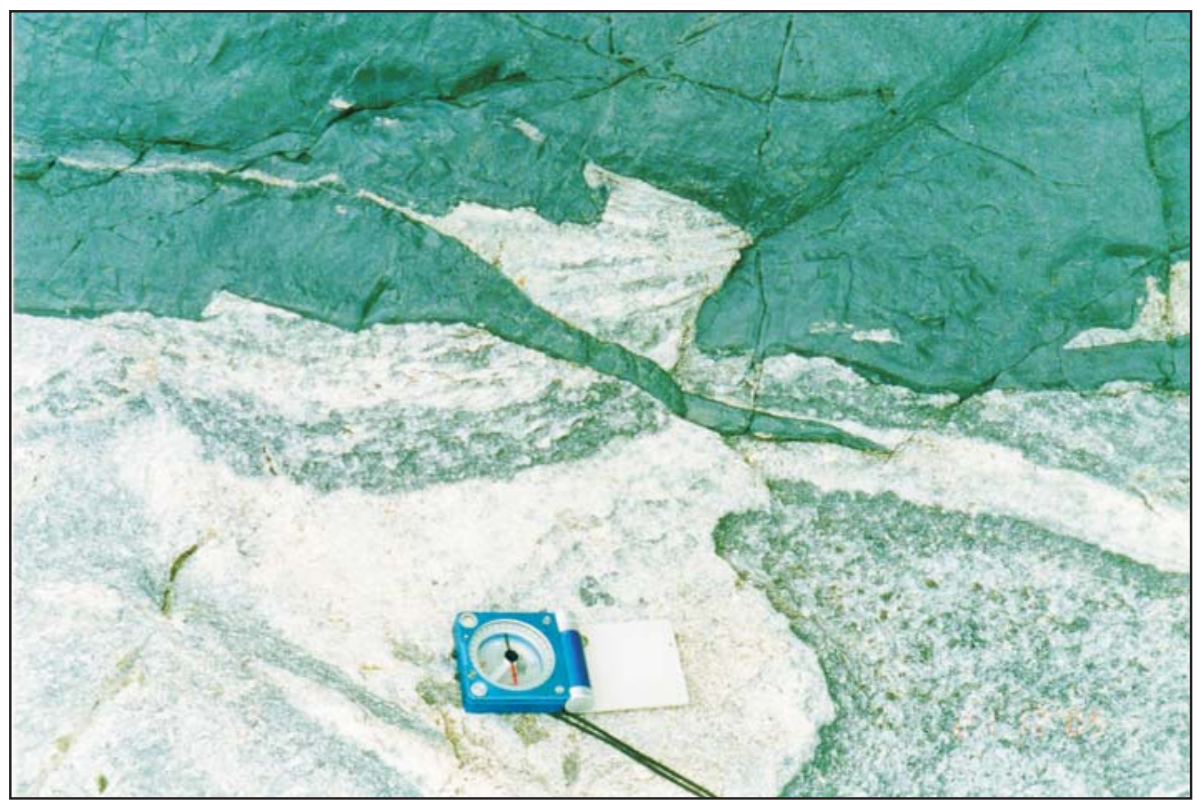

Foto o1 - Contato de dique de diabásio com migmatito encaixante. Praia do Curral, Ilhabela.

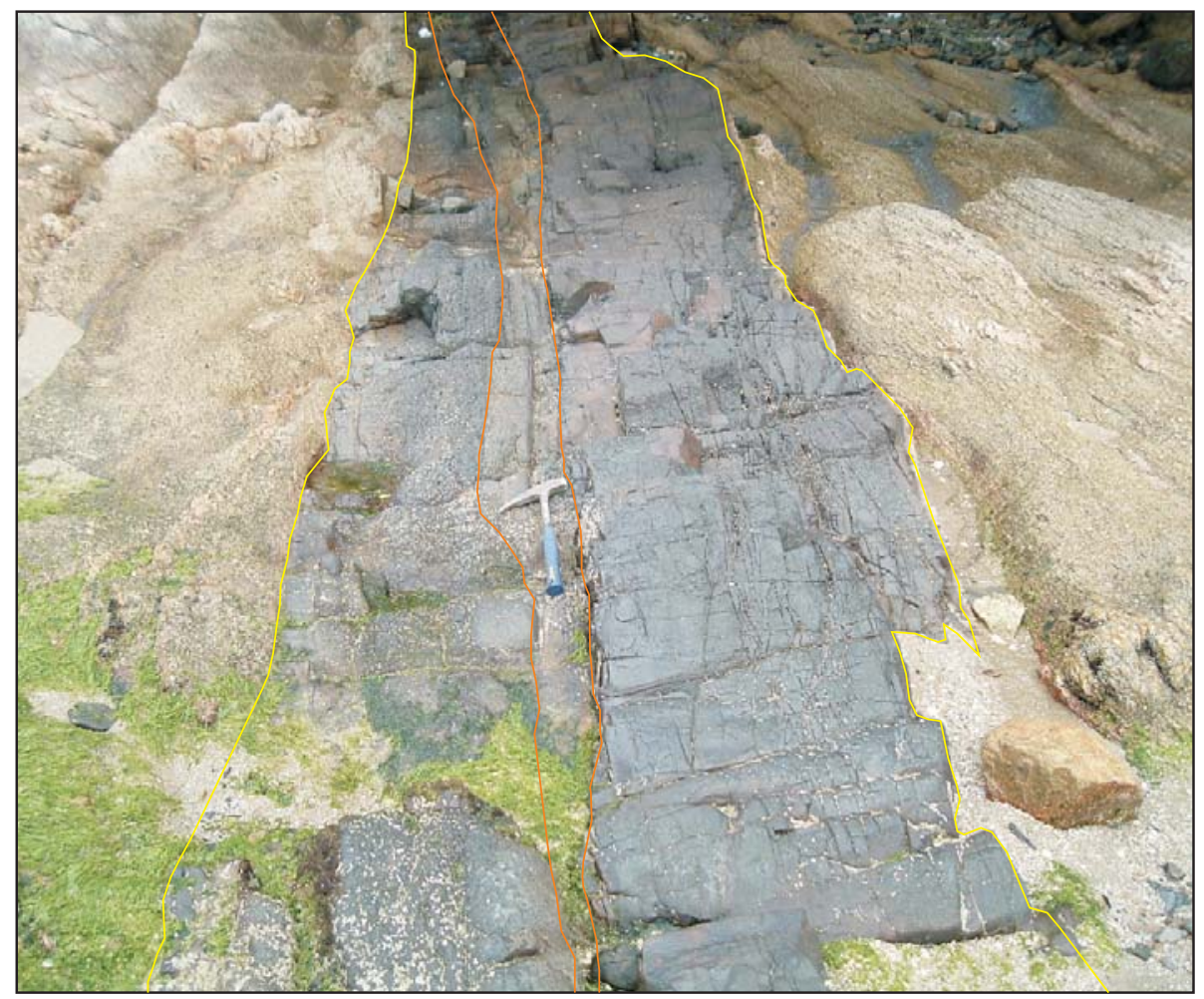

Foto 02 - Dique de diabásio (linha amarela) intrudido por dique de Lamprófiro (linha laranja). Ponta do Araça, São Sebastião. 


\section{Prancha II}

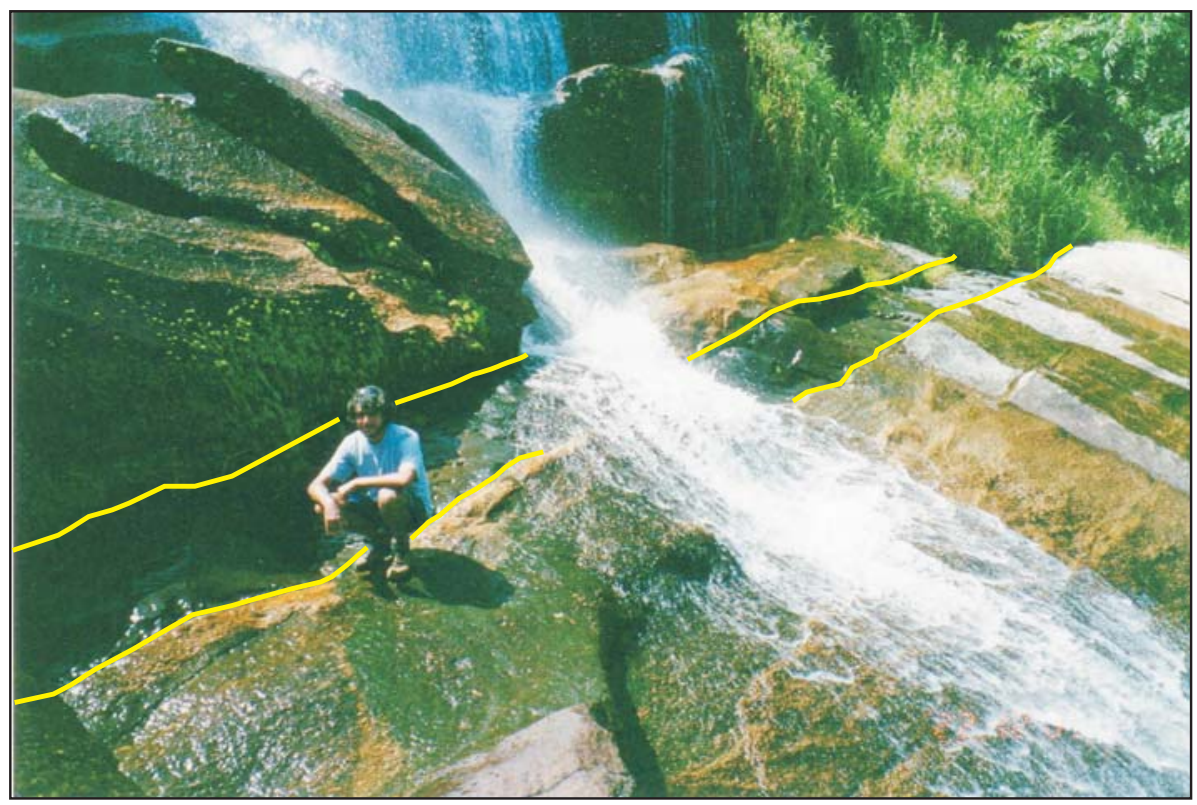

Foto 03 - Dique de diabásio com geometria retilínea. Cachoeira dos Três Tombos, Ilhabela.

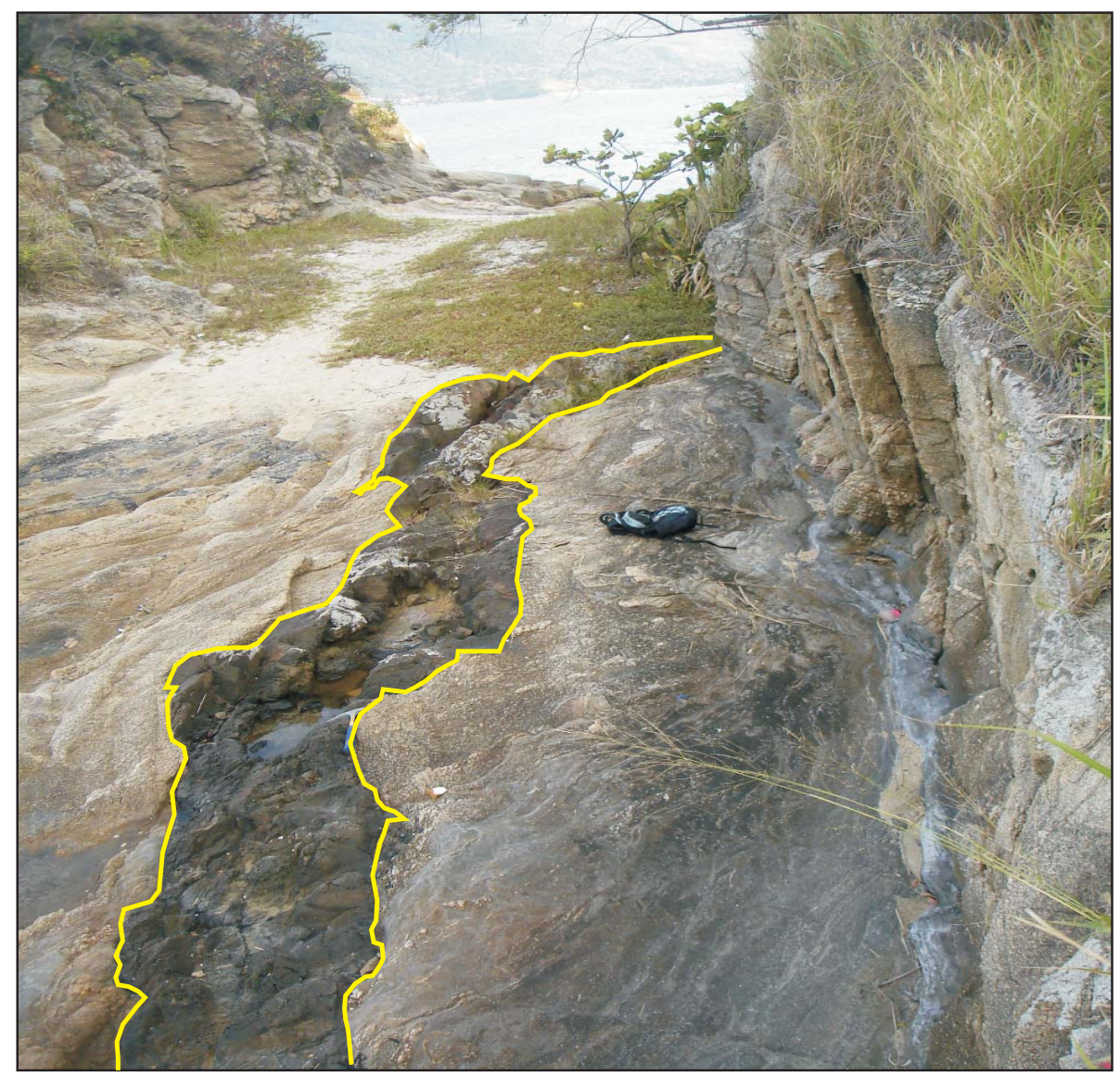

Foto 04 - Dique de diabásio com geometria segmentada. Ponta do Araça, São Sebastião. 


\subsubsection{Ubatuba-Paraty-Angra dos Reis}

Na porção norte de Ubatuba, passando por Paraty e Angra dos Reis, os diques descritos foram classificados em campo como diabásio de textura fanerítica fina a média, equigranular, e mineralogia formada por plagioclásio e piroxênio, com ilmenita, magnetita e pirita como opacos acessórios. Neste trecho, a geometria dos corpos é predominantemente retilínea, com menor ocorrência de segmentos com terminações abruptas. Os contatos com a rocha encaixante são bruscos, com ou sem bordas de resfriamento. Geralmente, exibem fraturas de resfriamento subparalelas e/ou transversais ao contato com a encaixante

Os diques estudados apresentam direção predominante NE-SW, com predomínio de diques entre as direções N40E e N60E (Figura 23A). Os mergulhos desses corpos mostram caimentos dominantemente de alto ângulo para os quadrantes NW e SE (Figura 23B).

Nessa região é marcante a presença de fraturas, principalmente paralelas e subparalelas aos diques (Figura 23C). No trecho do litoral, a foliação milonítica regional observada nas rochas encaixantes apresenta fortes inflexões, marcada pela morfologia da linha de costa. Neste segmento, a foliação milonítica apresenta direção geral em torno de N45E com mergulhos de alto ângulo para o quadrante NW. Em alguns locais, esta foliação muda entre N-S e N20W (Figura 23D).

Damasceno (1966) chama atenção para a retilinearidade dos diques da região de Ubatuba. Nossas observações reafirmam esse fato, e estendem essa característica para os diques entre Paraty e Angra do Reis, onde também predominam diques com geometria retilínea, e mais raramente segmentada (Prancha III - Foto 05 e Foto 06). Em alguns diques ocorrem bordas de resfriamento e feições rúpteis da encaixante registradas nos segmentos de diques com terminações abruptas, caracterizadas como chifres, saltos e apófises (Pranchas IV e V). 

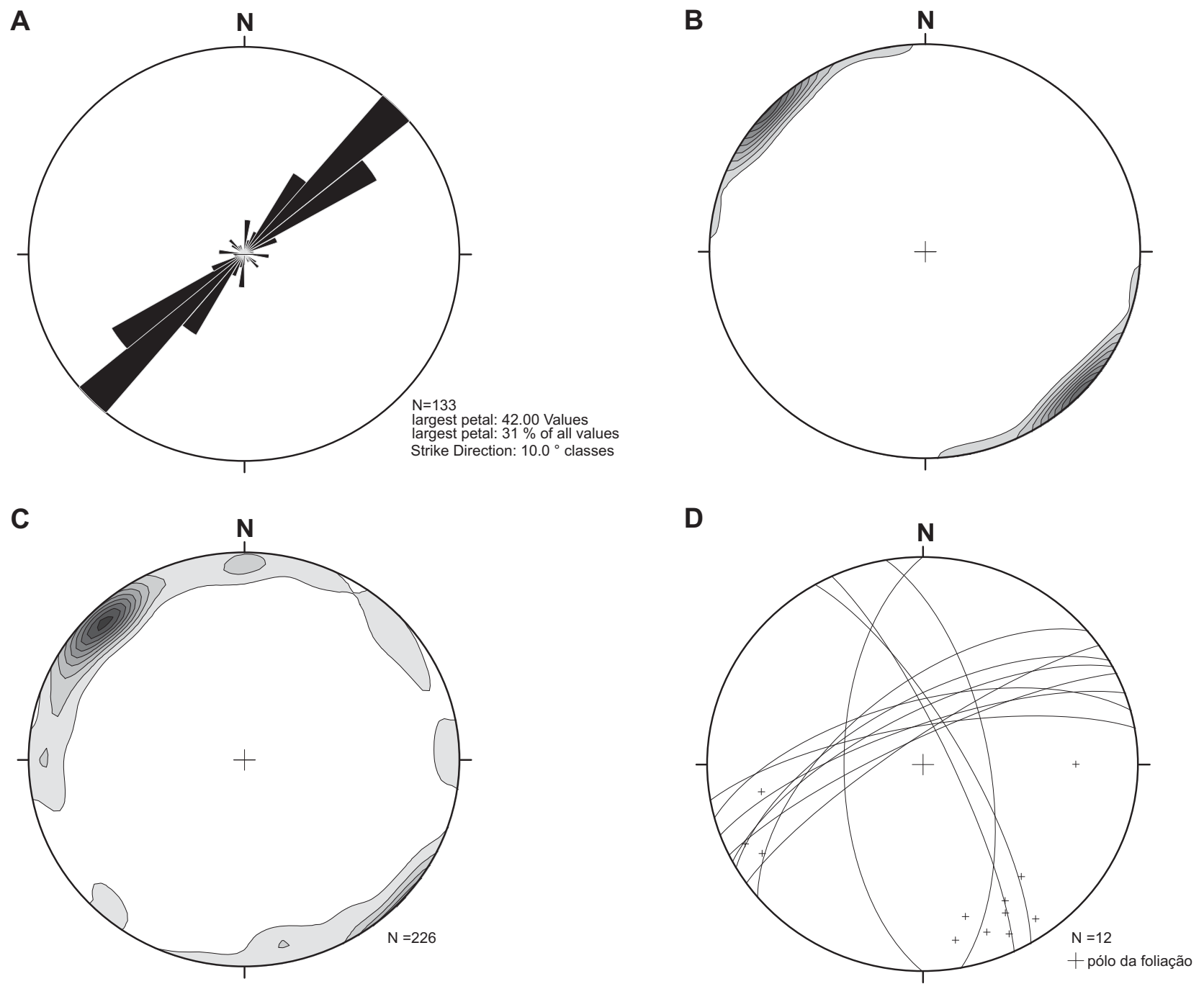

Figura 23 - A) Diagrama de rosácea representando 133 diques de diabásio entre Ubatuba, Paraty e Angra dos Reis. Dados obtidos nesta dissertação e compilados dos trabalhos de Damasceno (1966). B) Diagrama de contornos dos diques indicando o predomínio de mergulhos subverticais. C) Diagrama de contornos de atitude de fraturas nas rochas encaixantes dos diques. Notar a presença de fraturas subparalelas à direção dos diques. D) Projeção estereográfica da atitude da foliação regional do embasamento pré-cambriano . 


\section{Prancha III}

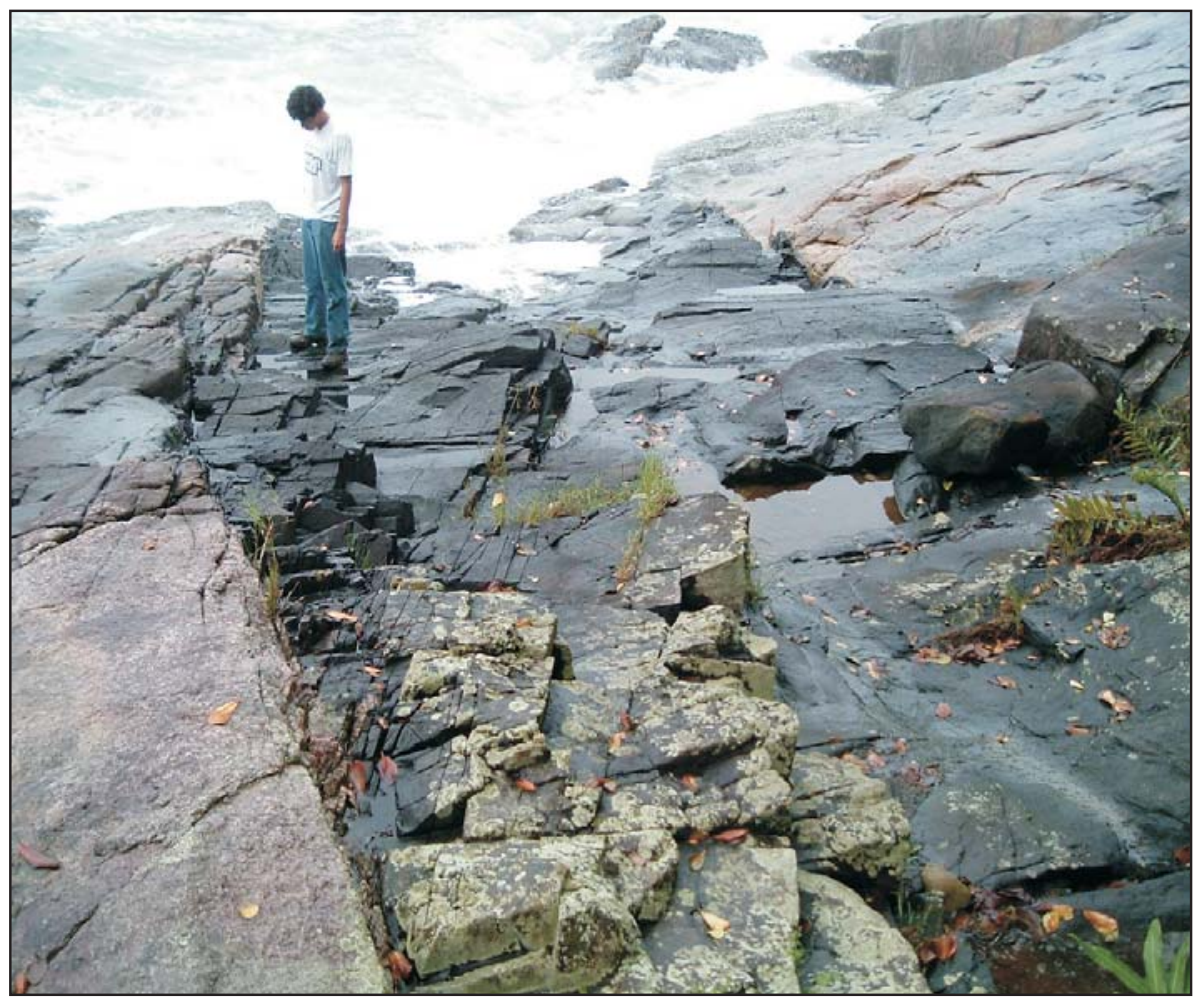

Foto 05 - Dique de diabásio com geometria retilínea. Praia do Centro, Ubatuba. Foto : Claudio Riccomini.

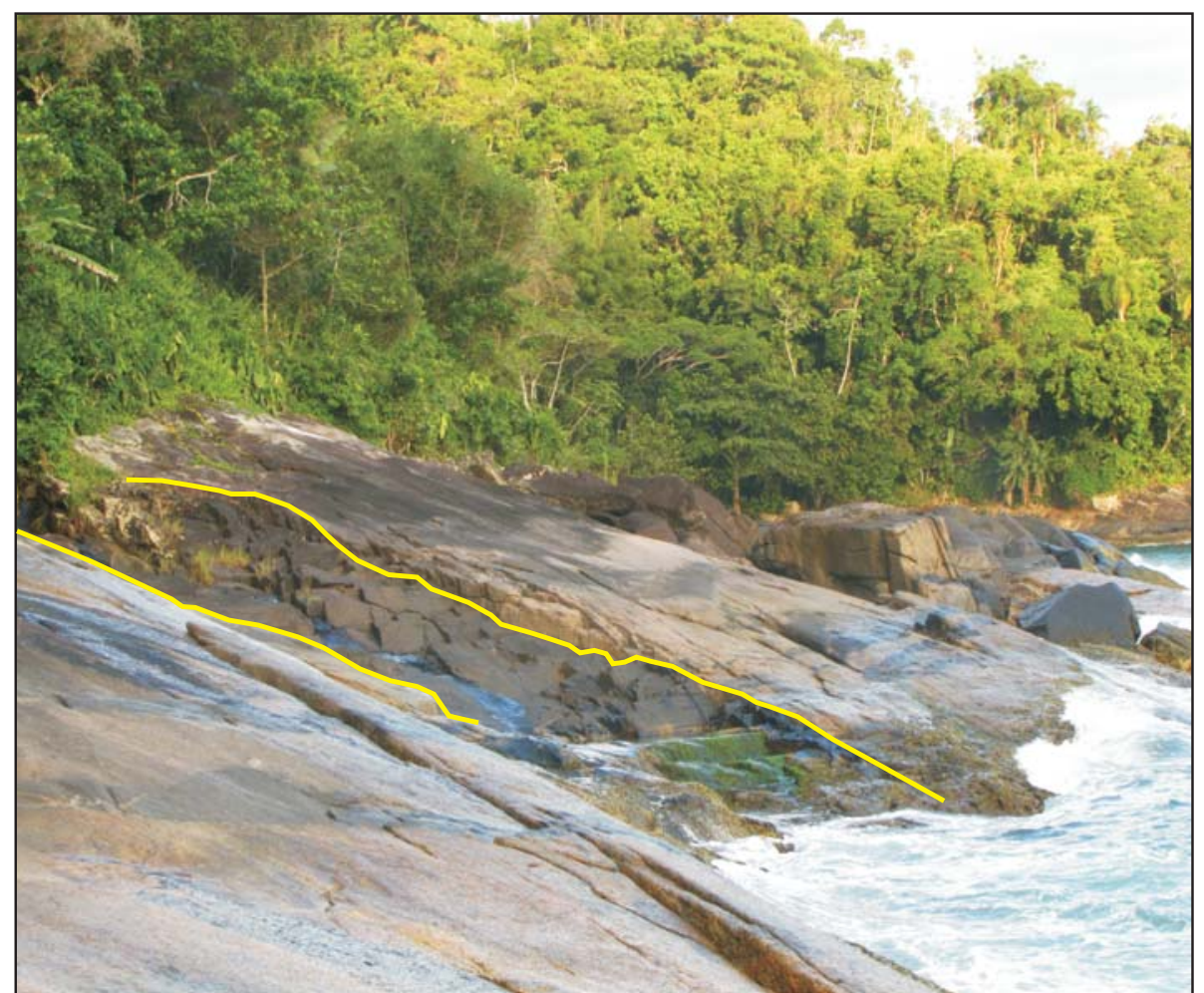

Foto o6 - Dique de diabásio com geometria retilínea. Praia Vermelha, Ubatuba. A espessura do dique é de aproximadamente 4,om. 


\section{Prancha IV}

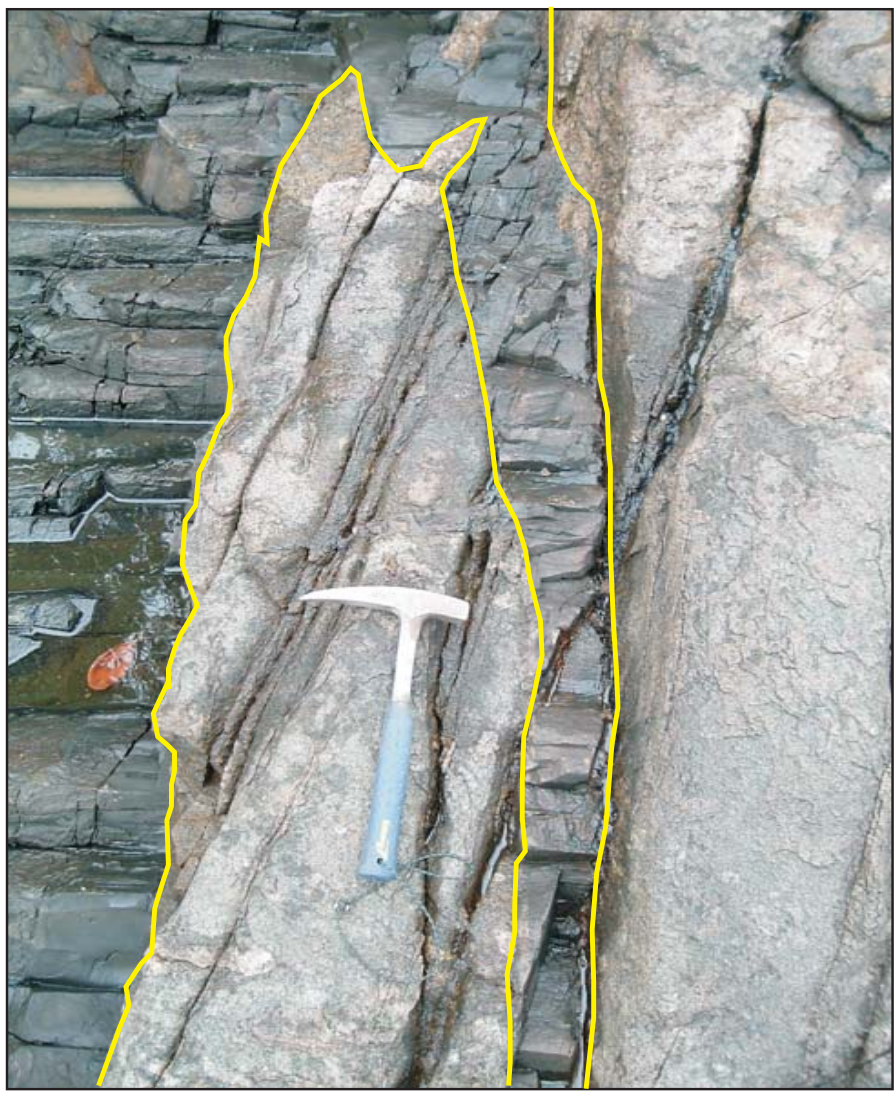

Foto 07 - Dique de diabásio com geometria retilínea e apófise paralelo ao dique. Praia do Centro, Ubatuba. Notar o intenso fraturamento da encaixante. Foto : Claudio Riccomini.

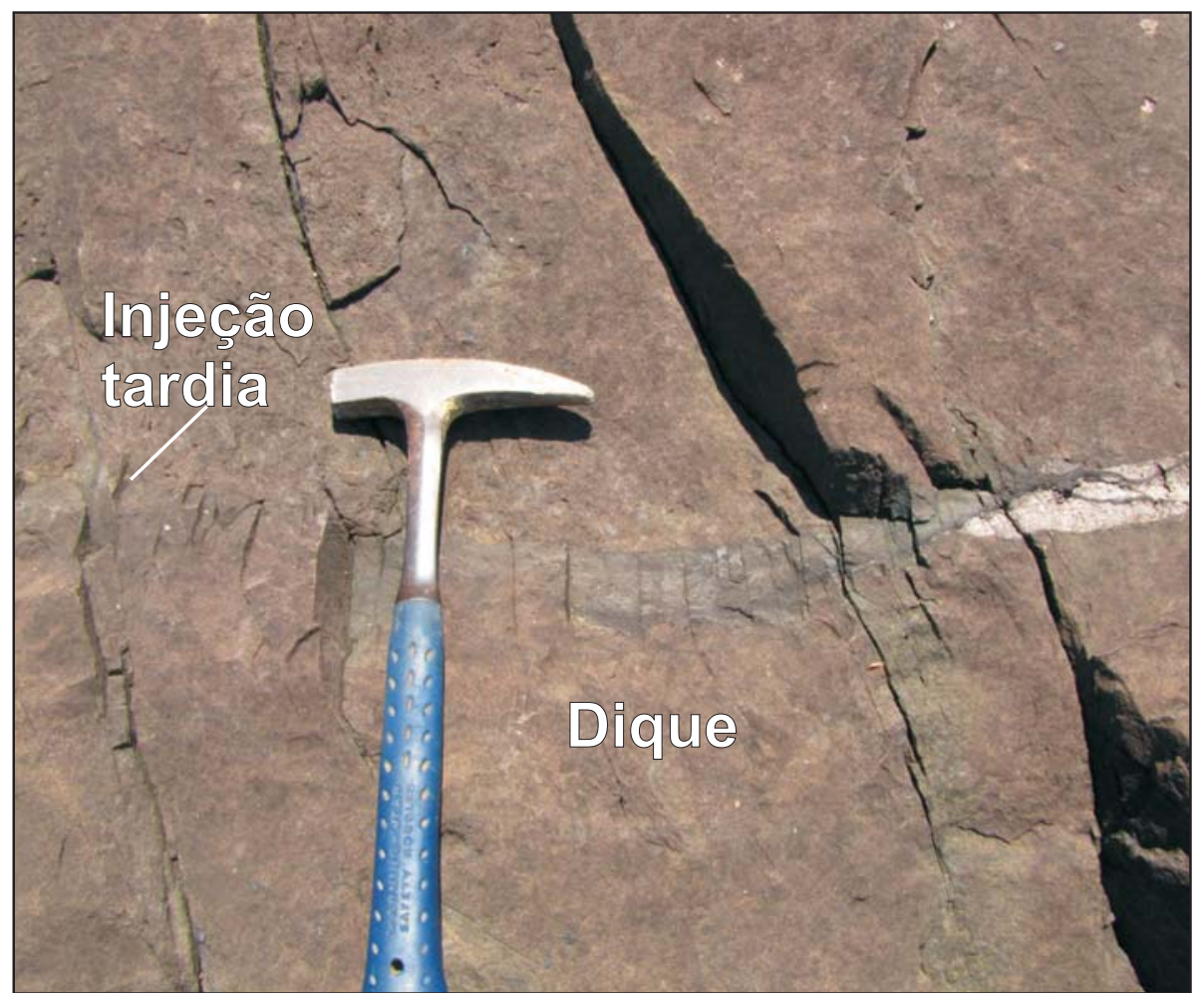

Foto 08 - Dique de diabásio mostrando fase de injeção magmática tardia. Praia de Mambucaba, Paraty. 


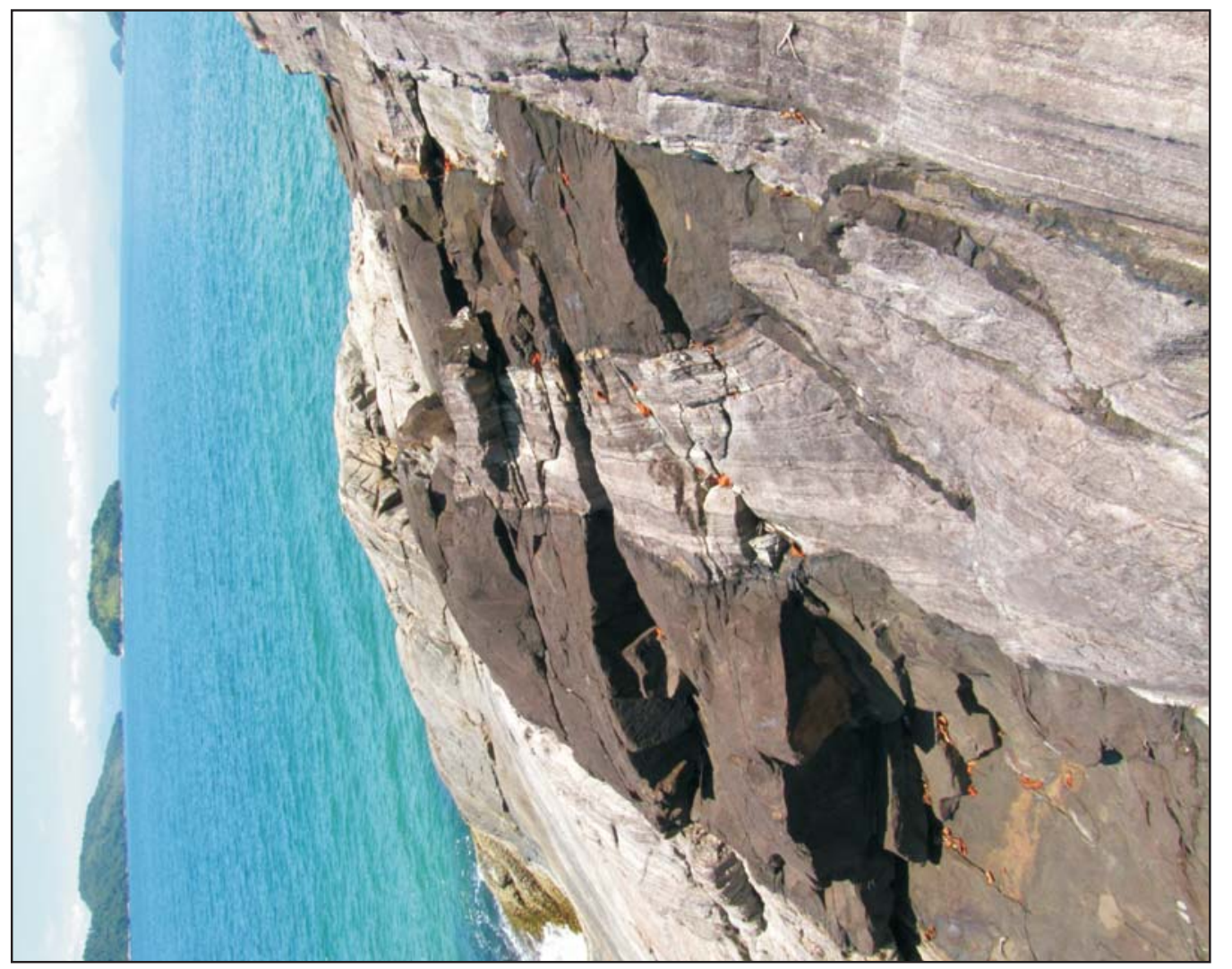

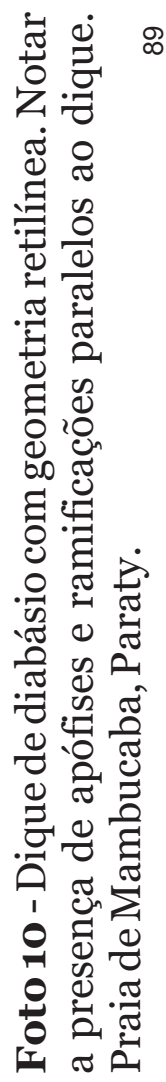

$\frac{7}{0}$
$\frac{1}{0}$
$\frac{c}{0}$
$\frac{1}{2}$

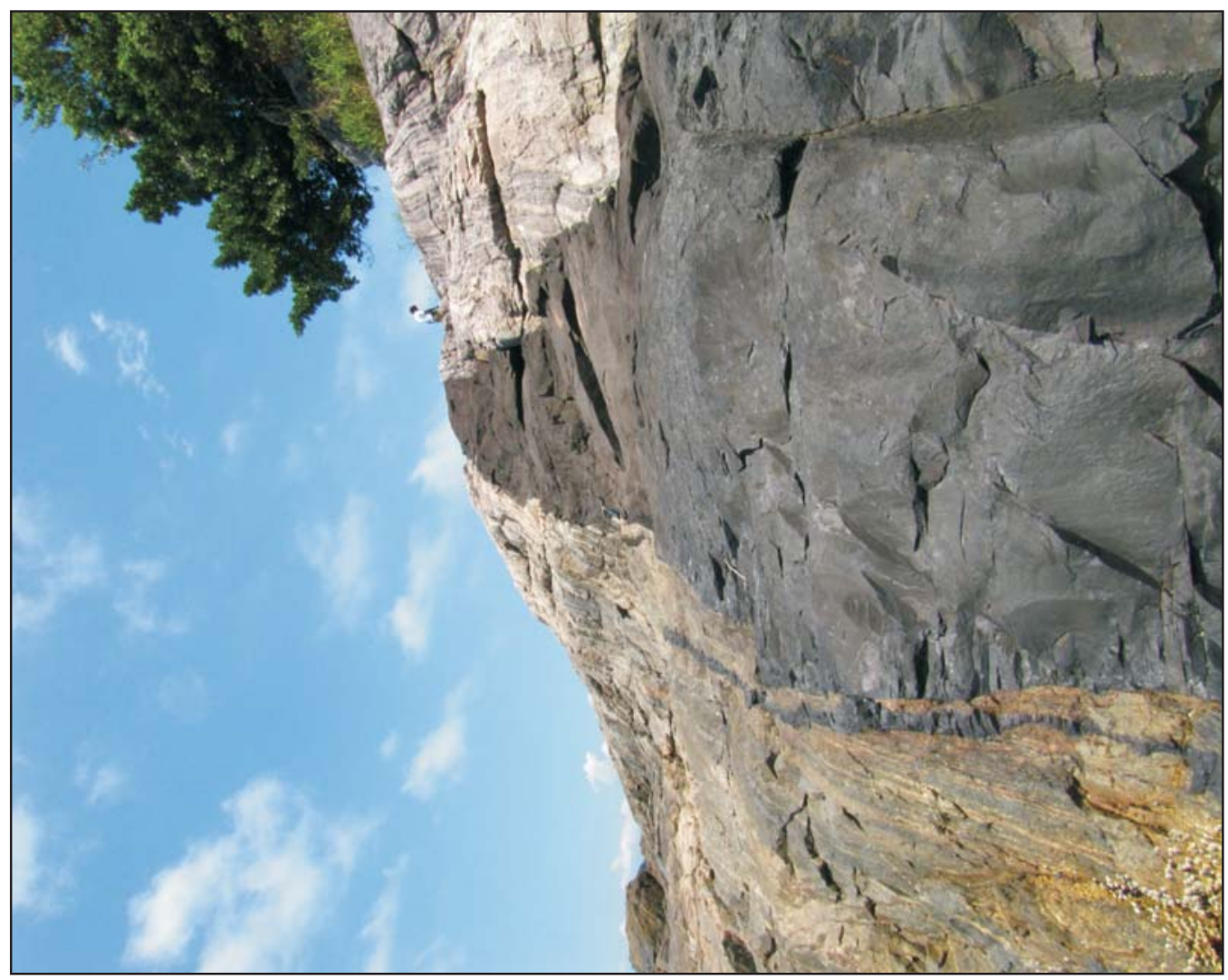

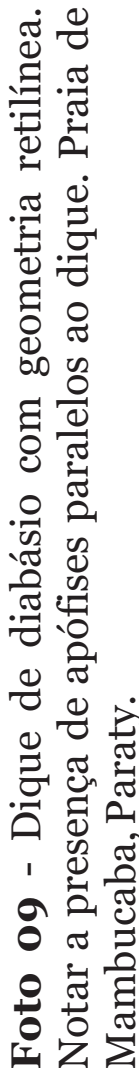




\subsubsection{Búzios-Cabo Frio}

No litoral norte do Estado do Rio de Janeiro foram descritos diques de diabásio entre os municípios de Búzios e Cabo Frio. Tais diques são formados por rochas de textura afanítica a fanerítica fina inequigranular. A mineralogia é formada por plagioclásio e piroxênio, com ilmenita e magnetita como opacos acessórios. Tetzner (2002) classificou os diques desse segmento como rochas de texturas tipicamente subvulcânicas (intergranular, intersertal e subofítica), com mineralogia essencial formada por plagioclásio (An50-90), clinopiroxênio (augita-pigeonita) e raros cristais de olivina.

Os diques estudados apresentam direção predominante NE-SW, com maior ocorrência entre as direções N40-50E (Figura 24A). Os mergulhos desses corpos mostram caimentos dominantemente de alto ângulo para os quadrantes NW e SE (Figura 24B).

Diferente dos enxames Florianópolis e dos outros segmentos do Enxame Serra do Mar, os diques do segmento Búzios-Cabo Frio truncam em alto ângulo o bandamento dos gnaisses encaixantes e ocorrem paralelos à falhas e fraturas de direção geral NE, muito persistentes na região (Figura 24C). Estas falhas apresentam intensas zonas de brechas, com registro de vários episódios de reativação. (vide Ferrari 2001, Rubim 2004). Os diques apresentam terminações abruptas como chifres, degraus e saltos, confirmando o estado rúptil da encaixante durante a intrusão. No contato com a encaixante ocorrem bordas de resfriamento, às vezes com formação de taquilito. Internamente ao dique, ocorrem fraturas de resfriamento perpendiculares ou transversais às paredes dos diques.

Neste segmento, os diques intrudem cianita-silimanita-granada-biotita gnaisse migmatitítico. Estas rochas apresentam bandamento composicional paralelo à foliação metamórfica, bem marcada em porções micáceas. Ocorrem intercalações de granada anfibolito de textura granoblástica paralelos ao bandamento composicional, normalmente de baixo ângulo e direções variáveis em torno de N-S (Figura 24D). 

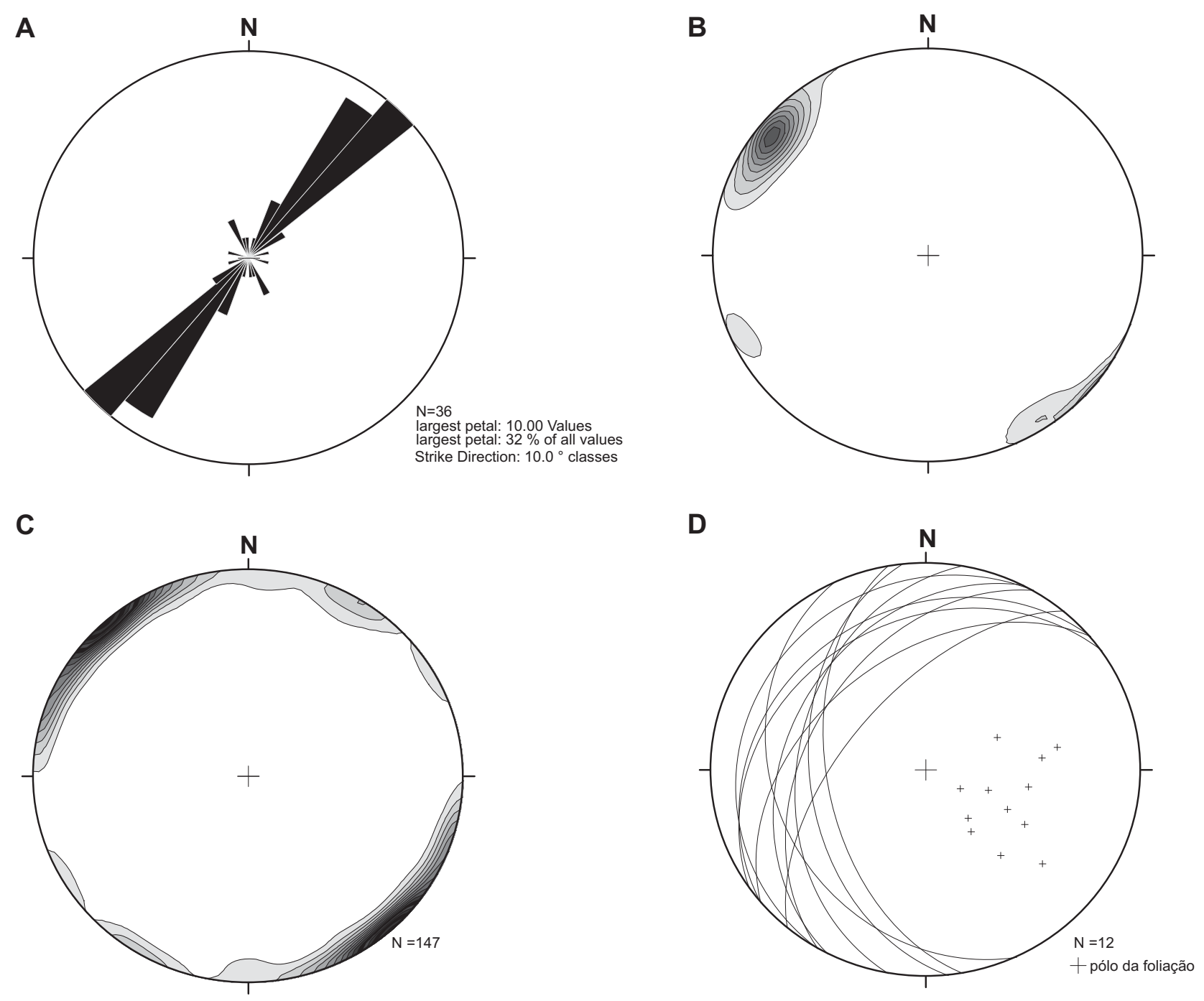

Figura 24 - A) Diagrama de rosácea representando 36 diques de diabásio entre BúziosCabo Frio. Dados obtidos nesta dissertação. B) Diagrama de contornos dos diques indicando o predomínio de mergulhos subverticais. C) Diagrama de contornos de atitude de fraturas nas rochas encaixantes dos diques. D) Notar a presença de fraturas subparalelas à direção dos diques.Projeção estereográfica da atitude da foliação regional do embasamento pré-cambriano. 


\subsubsection{Discussão sobre o Enxame de Diques Serra do Mar}

A direção preferencial dos diques em torno de N40E e N50E é persistente em todo Enxame Serra do Mar (Santos-Rio de Janeiro), indicando a abrangência regional do magmatismo intrusivo. Nesta região, o Enxame Serra do Mar pode ser definido como um enxame linear paralelo às bordas do Rift Sul-Atlântico.

Os estudos realizados neste enxame indicaram o predomínio de diques com geometria retilínea, sugerindo que a abertura dessas fraturas (dilatação) ocorreu de acordo com os mecanismos de ruptura do Modo I (Pollard 1987). Dessa forma, podemos considerar que as fraturas reativadas e/ou neoformadas durante a intrusão desses diques ocorreu a partir de mecanismos de fraturamento hidráulico, conforme o modelo proposto em Delaney et al. (1986) e Jolly \& Sanderson (1995). Exceto uma única ocorrência de um dique preenchendo uma falha N35E subvertical com rejeito aparente direcional, sinistral, não foram observados deslocamentos de marcadores pretéritos nas rochas encaixantes dos diques indicadores de intrusões não dilatantes. Esta observação é corroborada por Damasceno (1966) e Tetzner (2002).

A direção preferencial dos diques entre N40E e N50E é persistente em todo Enxame Serra do Mar (Santos-Rio de Janeiro), indicando a abrangência regional do magmatismo intrusivo e a homogeneidade do campo de tensões. A direção preferencial dos diques indica que o esforço principal mínimo ( $\sigma 3)$ variou entre N50W a N40W, paralelamente à direção de máximo estiramento crustal.

\section{2 - Enxame de diques de Ponta Grossa}

A origem e os aspectos evolutivos do Arco de Ponta Grossa, segundo alguns autores, remontam ao Paleozoico passando por uma série de reativações até o Paleógeno (vide Ferreira 1982 ${ }^{\mathrm{a}}$, Ferreira 1982 ${ }^{\mathrm{b}}$, Almeida 1982, Sadowski 1987, Machado Junior 2000, Franco-Magalhães 2010). Segundo Almeida (1976), o Arco de Ponta Grossa representa uma estrutura de soerguimento com eixo orientado na direção NW com caimento geral para a mesma direção exposto no leste do Paraná (Figura 21). O efeito erosivo diferencial presente nas unidades geológicas nos domínios do Arco de Ponta Grossa faz com que o mesmo seja caracterizado por uma marcante reentrância no 
embasamento e nas unidades paleozoicas da borda leste da Bacia do Paraná. Sadowski (1987) indica a continuidade do Arco de Ponta Grossa em território africano através do Arco de Mossamedes (Namíbia-Angola). De acordo com Almeida (1976) não se observa atividade tectônica vinculada ao Arco de Ponta Grossa afetando os sedimentos da Bacia de Santos, o que limitaria a principal fase de atividade desta estrutura ao intervalo Aptiano-Albiano.

Uma série de lineamentos estruturais subparalelos ocorre associada ao Arco de Ponta Grossa: I - Lineamento de Guapiara - este lineamento estrutural, reconhecido inicialmente por Vieira (1973) e formalizado como o limite setentrional do Arco de Ponta Grossa por Ferreira $\left(1982^{\mathrm{a}, \mathrm{b}}\right)$, representa uma extensa feição tectônica com pelo menos $600 \mathrm{~km}$ de comprimento e largura entre $20 \mathrm{~km}$ e $100 \mathrm{~km}$ orientado na direção N45W. Ferreira (1982) considera a planície litorânea da região de Iguape (SP) como o início do Lineamento de Guapiara, atravessando os terrenos Pré-Cambrianos onde coincide com um denso enxame de diques de diabásio (Alagarte 1972, Machado Junior 2000) e penetra na Bacia do Paraná até a confluência dos rios Verde e Paraná; II Lineamento de São Jerônimo - Curiúva e III - Lineamento do Rio Alonzo - estão localizados na região central do Arco de Ponta Grossa. Apresentam como característica marcante a grande concentração de diques de diabásio desde os terrenos PréCambrianos até as sucessões sedimentares da Bacia do Paraná, estendendo-se por cerca de $600 \mathrm{~km}$ com larguras entre $80 \mathrm{~km}$ e $100 \mathrm{~km}$ com direção preferencial N45-55W; IV Lineamento do Rio Piquiri - representa o limite meridional do Arco de Ponta Grossa. Este lineamento apresenta marcante destaque em imagens de sensores remotos conforme observado por Soares et al. (1982), constituindo um feixe de lineamentos orientados preferencialmente segundo a direção N60W com uma extensão aproximada de $500 \mathrm{~km}$ com largura variando entre $20 \mathrm{~km}$ e $100 \mathrm{~km}$. Com exceção do alinhamento do Rio Piquiri, definido por Ferreira $\left(1982^{\mathrm{a}, \mathrm{b}}\right)$ e interpretado por este autor como o limite meridional do Arco de Ponta Grossa, os demais lineamentos foram propostos por Vieira (1973).

A observação de mapas geológicos da região mostra claramente a influência desses lineamentos no condicionamento das sucessões mesozoicas da Bacia do Paraná (Figura 26). Apesar disso, diversos autores (e.g. Ferreira 1982 $2^{\mathrm{a}, \mathrm{b}}$, Fúlfaro et al. 1982, Zalán et al. 1990, Machado Jr 2000), baseando-se em análises principalmente de isópacas calculadas a partir da descrição de poços profundos perfurados para a pesquisa 
de hidrocarbonetos, coincidentemente mostram inflexões de direção NW no contorno de isolinhas de espessura de unidades paleozoicas na atual região sob influência estrutural do Arco de Ponta Grossa. Este fato aparenta representar que esta região tenha se comportado como embasamento da Bacia do Paraná durante o paleozoico, sem constituir a feição positiva de arco estrutural que passa a ter durante o NeojurássicoEocretaceo, não existindo evidências diretas de influência tectônica do Arco de Ponta Grossa durante a época de sedimentação das sucessões paleozoicas, conforme evidenciado por Franco-Magalhães (2009) e Franco-Magalhães et al. (2010) em um estudo da história de exumação do Arco de Ponta Grossa através de análises de termocronologia por traço de fissão em apatita e zircão.

Os resultados apontam 3 eventos térmicos, interpretados pelos autores como períodos de exumação da região, sendo eles: (1) Eocretaceo (idades de traços de fissão em zircão entre $138 \pm 51$ Ma e $107 \pm 22$ ); (2) Neocretaceo Superior (idades de traços de físsão em zircão entre $90 \pm 14$ Ma e $69 \pm 21 \mathrm{Ma}$; e idades de traços de fissão em apatita entre $74 \pm 14$ Ma e $66 \pm 2 \mathrm{Ma}$ ); (3) Oligoceno-Mioceno (idades de traços de fissão em apatita entre $26 \pm 3 \mathrm{Ma}$ e $14 \pm 2 \mathrm{Ma}$ ). Segundo os autores, idades observadas no evento 1 estão relacionadas aos processos tectônicos, magmáticos e de exumação do evento de ruptura do Gondwana Sul-Ocidental. O evento 2 estaria relacionado ao soerguimento do embasamento cristalino como resposta à uma anomalia térmica causada pela Pluma de Trindade sob o sudeste brasileiro, enquanto o evento 3 estaria associado à reativação de antigas zonas de falhas durante a instalação das bacias sedimentares vinculadas às bacias tafrogênicas do Rift Continental do Sudeste do Brasil (Riccomini 1989), na Bacia de Curitiba e nos grábens de Guaraqueçaba, Sete Barras e Cananéia. Apesar dos dados evidenciarem apenas esses eventos, Franco-Magalhães (2009) aponta a existência de um evento entre o Neocretaceo e o Eopaleoceno, onde teria ocorrido soerguimento regional generalizado e erosão das bacias sedimentares instaladas sobre a plataforma sulamericana, e ao tectonismo gerador do segmento central do Rift Continental do Sudeste do Brasil.

Os diques intrudidos ao longo do Arco de Ponta Grossa representam a mais significativa ocorrência de atividade magmática intrusiva no Eocretaceo durante o evento Serra Geral (Melfi et al. 1988). Tais diques estão encaixados em rochas précambrianas do embasamento da Bacia do Paraná e nas sucessões sedimentares anteriores à Formação Serra Geral. Esses diques apresentam orientação 
predominantemente NW-SE, concentrando a maior parte das ocorrências na região compreendida entre os lineamentos São Jerônimo-Curiúva e Rio Alonzo, onde diques são interpretados a partir de mapas aeromagnéticos com uma frequência de 1 a 4 corpos por $\mathrm{km}^{2}$ (Ferreira 1982 $2^{\mathrm{a}, \mathrm{b}}$ ). A largura aflorante desses corpos varia de 20 a 50 metros (Marini et al. 1967). Para a extensão, foram encontrados valores entre 1 e 50 quilômetros, sendo que na região são comuns anomalias magnéticas com até 200 quilômetros, geralmente atribuídas a diques de diabásio (Ferreira 1982 ${ }^{\mathrm{a}, \mathrm{b}}$ ).

Fúlfaro \& Suguio (1967) descrevem a ocorrência de diques de diabásio orientados preferencialmente na direção NW e subordinadamente NE nos domínios do Arco de Ponta Grossa intrudindo a sucessão paleozoica da Bacia do Paraná. Os autores interpretaram os diques como possíveis condutos alimentadores dos derrames da Formação Serra Geral, uma vez que os diques apresentam-se sob os derrames. No entanto, Raposo (1995) descreve que na região de Fartura no Estado de São Paulo diques ocorrem cortando a pilha de rochas basálticas. Raposo \& Ernesto $\left(1989,1995^{\text {a }} \mathrm{e}\right.$ $1995^{\mathrm{b}}$ ) apresentam um estudo paleomagnético onde verificaram uma diferença entre o pólo magnético obtido em rochas extrusivas da Formação Serra Geral (Ernesto 2007) e o pólo magnético determinado nos diques associados ao enxame do Arco de Ponta Grossa, indicando os diques como posteriores aos derrames e colocados em diferentes episódios, uma vez que, diques de mesma composição mostraram orientação de magnetização distinta.

Em trabalho posterior, Raposo \& Ernesto $\left(1995^{b}\right)$, a partir de medidas de anisotropia de suscetibilidade magnética, sugerem que o fluxo de magma nesses diques ocorreu quase exclusivamente com componentes horizontais a sub-horizontais sugerindo grandes distâncias da fonte, ou mesmo diferentes fontes magmáticas. $\mathrm{O}$ envolvimento de mais de uma fonte também é evidenciado pelas diferentes composições químicas encontradas ao longo dos domínios do enxame de Ponta Grossa (Pinese 1989, Piccirillo et al. 1990, Benini 1992).

A composição dos diques é constituída predominantemente por andesibasaltos formados por plagioclásio $\left(\mathrm{An}_{30-60}\right)$, piroxênio (augita-pigeonita), magnetita, titanomagnetita, ilmenita, com pirita e calcopirita ocasionais. De acordo com Pinese (1989), em lâmina petrográfica os diques apresentam texturas subofítica, intergranular, intersertal e hialofítica, com ocorrência restrita de textura ofítica. 
Em algumas localidades dos domínios do Arco de Ponta Grossa ocorrem diques ácidos formados por dacitos e riodacitos com plagioclásio, piroxênio (augita-pigeonita), feldspato alcalino, quartzo, magnetita e titanomagnetita, ilmenita e apatita como acessórios (Benini 1992, Raposo 1995). A composição dos diques ácidos é semelhante às rochas vulcânicas ácidas do tipo Chapecó (Benini 1992).

\subsubsection{Estudos no Enxame de Diques de Ponta Grossa}

Neste enxame foram descritos 27 diques no interior dos Estados de São Paulo e Paraná, na região do Vale do Ribeira, nos municípios de Capão Bonito-SP, e Cerro Azul-PR, nos domínios dos lineamentos Rio Alonzo, São Jerônimo-Curiúva e Guapiara. Neste enxame, também foram compilados diques descritos nos trabalhos de Pinese (1989), Raposo (1995) e Coutinho (2008) espalhados desde o litoral até o interior da região limítrofe entre São Paulo e Paraná.

\subsubsection{Capão Bonito-Cerro Azul}

Os diques mapeados apresentam direção geral NW-SE com predomínio entre as direções N40W e N50W (Figura 25A). Os mergulhos dos diques mostram caimentos dominantemente de alto ângulo para os quadrantes NE e SW (Figura 25B). Similar ao segmento de Búzios-Cabo Frio do Enxame Serra do Mar, os diques do Arco de Ponta Grossa truncam em alto ângulo as estruturas regionais. Foi identificada, em campo, a ocorrência de falhas e fraturas de direção geral NW, muito persistentes na região, com ocorrência subordinada de fraturas NE (Figura 25C). Os diques descritos intrudem principalmente rochas graníticas ediacaranas das suítes intrusivas Morro Grande e Cunhaporanga (Prazeres-Filho 2005). Estas rochas apresentam foliação protomilonítica em torno de N35E e N50E com mergulhos de alto ângulo para os quadrantes SE e NW (Figura 25D).

Os diques descritos foram classificados em campo como diabásio, de coloração cinza escura a preta, textura fanerítica fina equigranular. Em lâminas petrográficas, Pinese (1989) descreveu essas rochas como formadas por tipos de granulação fina, com texturas tipicamente subvulcânicas do tipo subofítica, intergranular e intersertal. 

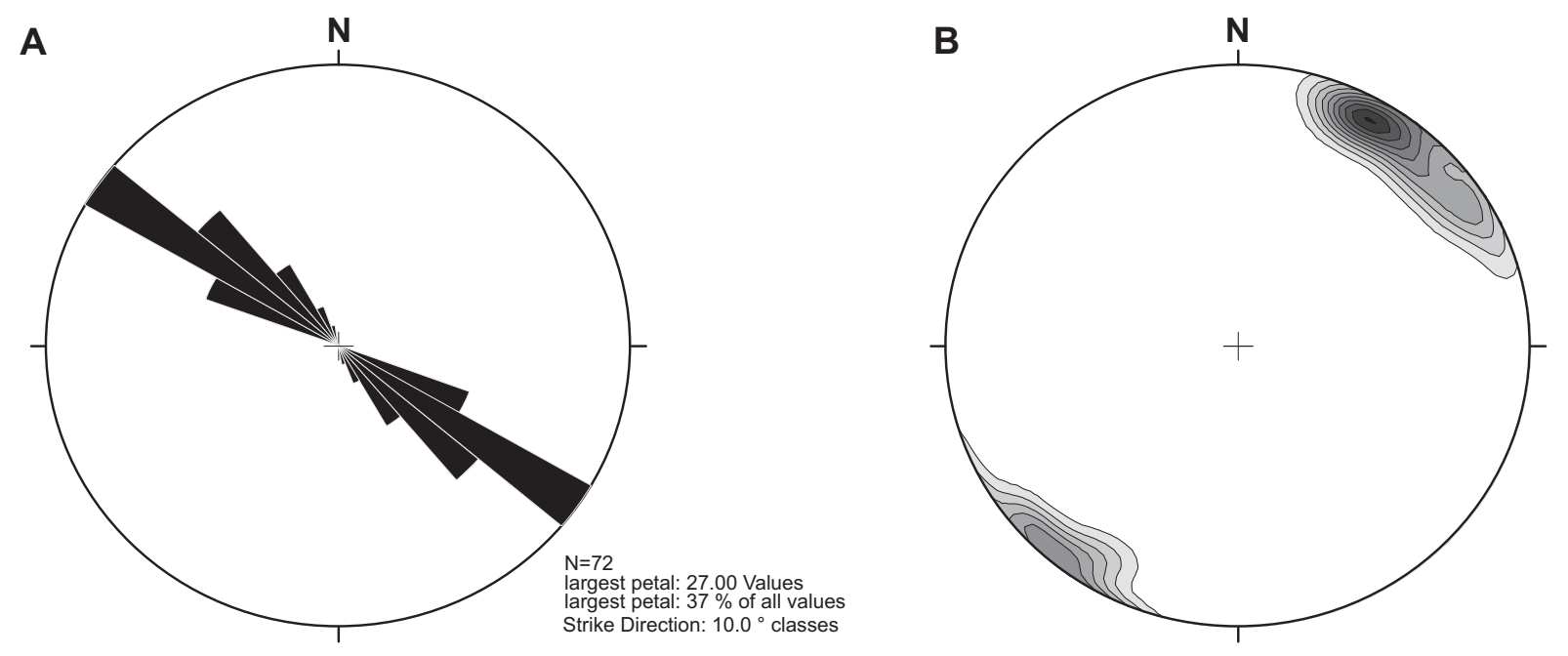

C
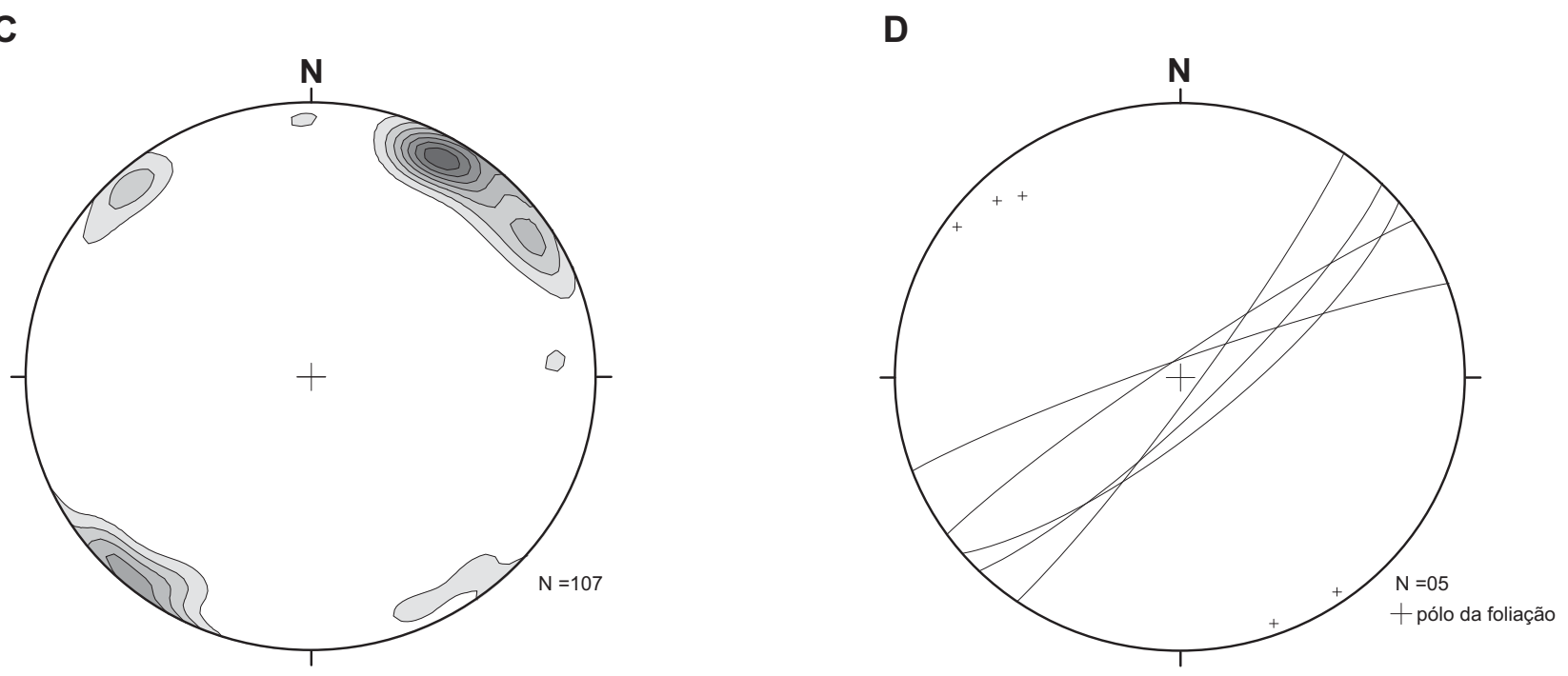

Figura 25 - A) Diagrama de rosácea representando 72 diques de diabásio nos domínios do Arco de Ponta Grossa. Dados obtidos nesta dissertação e compilados dos trabalhos de Pinese (1989), Raposo (1995) e Coutinho (2008). B) Diagrama de contornos dos diques indicando o predomínio de mergulhos subverticais . C) Diagrama de contornos de atitude de fraturas nas rochas encaixantes dos diques. Notar a presença de fraturas subparalelas à direção dos diques. D) Projeção estereográfica da atitude da foliação regional do embasamento pré-cambriano. 
Segundo o autor, essas rochas apresentam mineralogia essencial formada por plagioclásio $\left(\mathrm{An}_{55-80}\right)$, clinopiroxênio (augita-pigeonita), além de magnetita, ilmenita e pirita como opacos acessórios.

\subsubsection{Discussão sobre o Enxame de Ponta Grossa}

A direção preferencial dos diques em torno de N40W e N50W é persistente em todo Enxame de Ponta Grossa, e pode ser definido como um enxame linear transversal às bordas do Rift Sul-Atlântico, conforme já descrito por diferentes autores (e.g. Fúlfaro \& Suguio 1967, Pinese 1989, Coutinho 2008 e outros).

Os estudos realizados neste enxame indicaram o predomínio de diques com geometria retilínea, sugerindo que a abertura dessas fraturas (dilatação) ocorreu de acordo com os mecanismos de ruptura do Modo I (Pollard 1987). Dessa forma, podemos considerar que a formação/reativação de fraturas durante a intrusão desses diques ocorreu por processos de fraturamento hidráulico, conforme o modelo proposto em Delaney et al. (1986) e Jolly \& Sanderson (1995).

A direção preferencial dos diques entre $\mathrm{N} 40 \mathrm{~W}$ e N50W indica que o esforço principal mínimo $(\sigma 3)$ variou entre N50E a N40E, paralelamente à direção de máximo estiramento crustal. 


\section{3 - Enxames de diques Florianópolis}

Na Ilha de Santa Catarina e região continental adjacente são encontradas várias ocorrências de diques de rochas máficas relacionadas ao magmatismo Serra Geral reunidos no Enxame de Florianópolis (Figura 21).

Os diques do Enxame de Florianópolis intrudem rochas graníticas e metamórficas précambrianas do embasamento da Bacia do Paraná em SC. De uma maneira geral, os contatos entre as unidades litoestratigráficas são tectônicos, marcados pela influência de importantes falhamentos regionais como a Zona de Cisalhamento Major Gercino (Bitencourt et al. 1989) e a Zona de Transcorrência Itajaí-Perimbó (Silva 1991).

A partir de estudos de anisotropia de susceptibilidade magnética e magnetismo de rocha, Raposo (1997) interpretou a direção de fluxo magmático em diques na ilha de Santa Catarina. De acordo com o trabalho a maioria dos diques estudados apresentaram fluxo vertical a inclinado e subordinadamente fluxo horizontal a subhorizontal. Em trabalho posterior, Raposo et al. (1998) realizaram investigações paleomagnéticas e geocronológicas nos mesmos diques. Os resultados indicaram um pólo paleomagnéticos localizado a 33,0E / 89,1S, e idades em duas concentrações principais, entre 128 e 126 Ma e 122 e 119 Ma. Esta faixa de idades mais jovens abrange o maior número de ocorrências de diques, e foram relacionados pelos autores à distensão crustal nos estágios finais do rifteamento, anteriormente à formação de crosta oceânica nesta latitude.

A faixa de ocorrência do Enxame de diques de Florianópolis está inserida no segmento terminal do Planalto Atlântico, apresentando a mesma complexidade de eventos de soerguimento e denudação observada em outras regiões da Serra do Mar. Análises de termocronologia por traço de fissão em apatita na região do distrito de exploração de fluorita em Santa Catarina revelaram eventos de soerguimento entre o fim

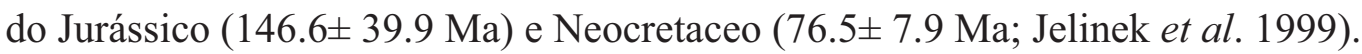

Do ponto de vista geoquímico, Marques (2001) mostrou a predominância de latiandesitos e andesibasaltos toleíticos, ocorrendo de maneira subordinada basaltos toleíticos e andesitos toleíticos e, ainda, diques pertencentes à série transicional, latitos e latibasaltos. A mineralogia desssas rochas é constituída predominantemente por 
plagioclásio $\left(\mathrm{An}_{50-60}\right)$, piroxênio (augita-pigeonita), magnetita, titanomagnetita, ilmenita, às vezes com pirita e calcopirita.

Coutinho (2008) descreve a ocorrência de 48 diques de diabásio espalhados no litoral de Santa Catarina entre Itajaí e Florianópolis. Com base em estudos petrográficos, o autor classificou estes diques como diabásio de textura intergranular com mineralogia essencial formada por plagioclásio $\left(\mathrm{An}_{40-60}\right)$, augita e mais raramente pigeonita. Como acessórios ocorrem ilmenita, magnetita, quartzo intersticial e apatita.

\subsubsection{Estudos no Enxame de Diques de Florianópolis}

No Enxame de Diques de Florianópolis foram estudados afloramentos na região de Bombinhas, a norte da ilha de Florianópolis, e entre as praias de Garopaba, Silveira, Barra de Ibiraquera e Ribanceira, a sul. Além disso, foram compilados dados direcionais e de ocorrência de diques na ilha de Florianópolis dos trabalhos de Brentan (2006), Tomazzoli \& Pellerin (2008), Coutinho (2008). Deste último também foram compilados diques da região de Itajaí. A apresentação dos estudos estruturais será feita com base em domínios onde os diques apresentam mesma associação litológica como encaixante. Assim foram separados dois segmentos: Itajaí-Bombinhas e Florianópolis-Imbituba.

\subsubsection{Itajai-Bombinhas}

Na região de Bombinhas, os diques estudados apresentam direção predominante NNE-SSW. A dispersão dos dados é relativamente pequena com predomínio de diques entre as direções N15E e N25E (Figura 26A). Os mergulhos desses corpos mostram caimentos dominantemente subvertical para WNW-ESE (Figura 26B). Em toda a região é marcante a frequência de fraturas oblíquas, ortogonais, paralelas e subparalelas aos diques (Figura 26C). A foliação milonítica regional observada nas rochas encaixantes apresenta atitude geral em torno de N45E, com mergulhos de alto ângulo, ás vezes subparalela à direção dos diques (Figura 26D). 

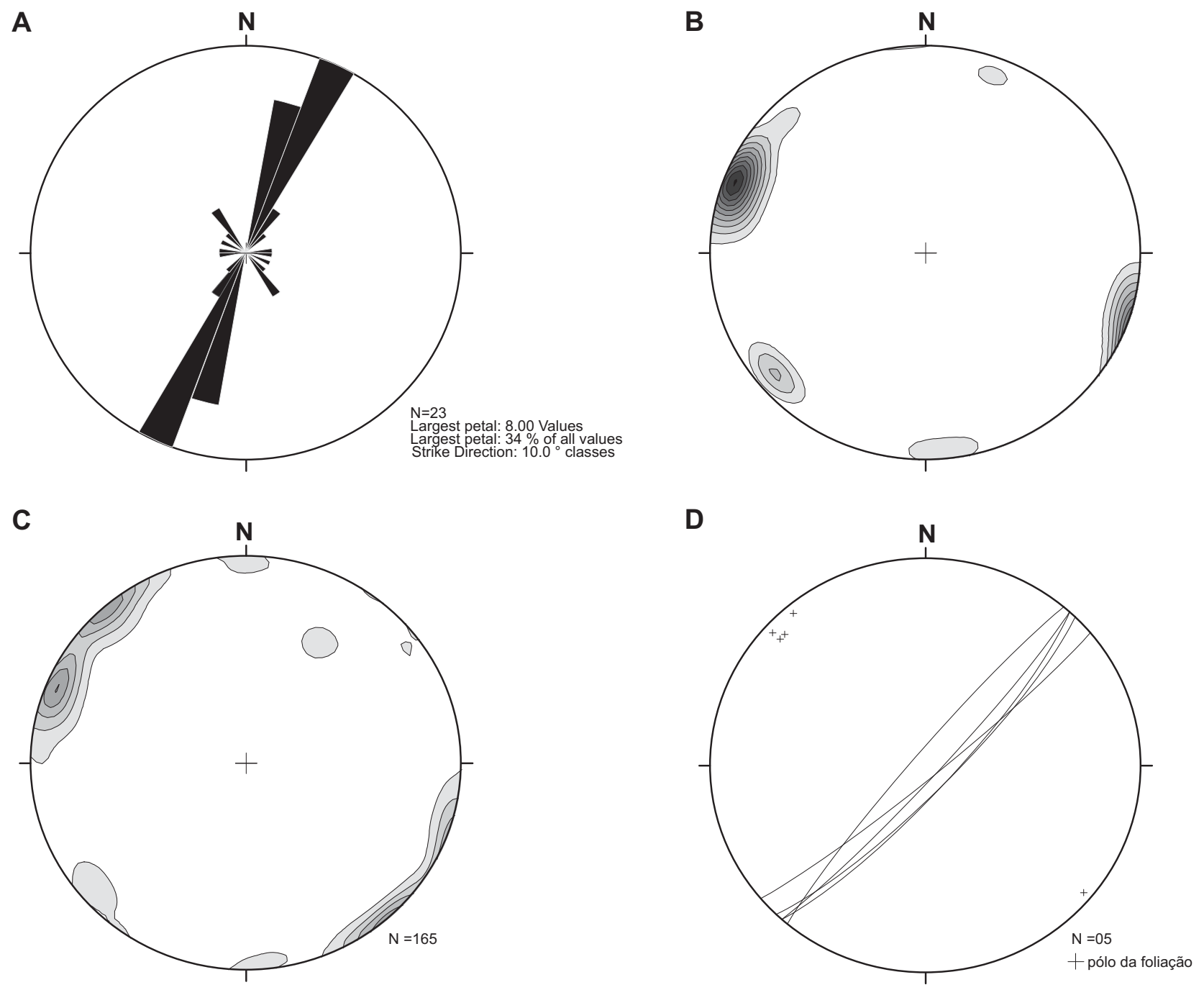

Figura 26 - A) Diagrama de rosácea representando 23 diques de diabásio entre Itajaí e Bombinhas. Dados obtidos nesta dissertação e compilados de Coutinho (2008). B) Diagrama de contorno da atitude dos diques indicando o predomínio de mergulhos subverticais. C) Diagrama de contornos de atitude de fraturas nas rochas encaixantes dos diques. Notar a presença de fraturas subparalelas à direção dos diques. D) Projeção estereográfica da atitude da foliação regional do embasamento pré-cambriano. 
Nesta região os diques intrudem principalmente migmatitos bandados e ortognaisses do Complexo Camboriú (Chemale Jr. et al. 1995). Os migmatitos foram descritos em campo como rochas bandadas de granulação média a grossa com leucossoma quartzo feldspático. O melanossoma é formado por anfibólio preto a esverdeado e biotita, isorientados em bandas centimétricas $(\sim 5 \mathrm{~cm})$. Estas feições encontram-se transpostas por uma marcante foliação blastomilonítica, registrada pela forte elongação e recristalização de porfiroblastos de quartzo e feldspato, com direção geral N40E.

A geometria dos diques é predominantemente retilínea (Prancha VI - Foto 11), geralmente com bordas de resfriamento marcada pela presença de taquilito. Ocorrem apófises distensionais paralelos ao dique (Prancha VI - Foto 12). Os diques apresentam contatos abruptos com a encaixante, confirmando o estado rúptil desta durante a intrusão.

\subsubsection{Florianópolis-Imbituba}

Os diques descritos no segmento Florianópolis-Imbituba apresentam direção geral NE-SW, com maior ocorrência de diques entre as direções N20E e N35E (Figura 27A) e caimentos subverticais predominantemente para o quadrante NE (Figura 27A).

Nessa região, os diques intrudem principalmente rochas graníticas do Batólito Pelotas (Fragoso-Cesar et al. 1986). De uma maneira geral, estas rochas são caracterizadas pela coloração rósea, textura fanerítica grossa a porfirítica com matriz fanerítica média, inequigranular. A mineralogia é formada por feldspato alcalino, quartzo, plagioclásio e anfibólio. Esses granitos estão extremamente faturados, com franco predomínio de fraturas de direção geral NE-SW e NW-SE (Figura 27B).

Os diques do segmento Florianópolis-Imbituba também apresentam geometria retilínea predominante. No entanto, apresentam a maior ocorrência de segmentos com terminações abruptas, como apófises, ramificações, pontes, chifres, saltos e degraus. (Pranchas VII, VIII e IX). 


\section{Prancha VI}

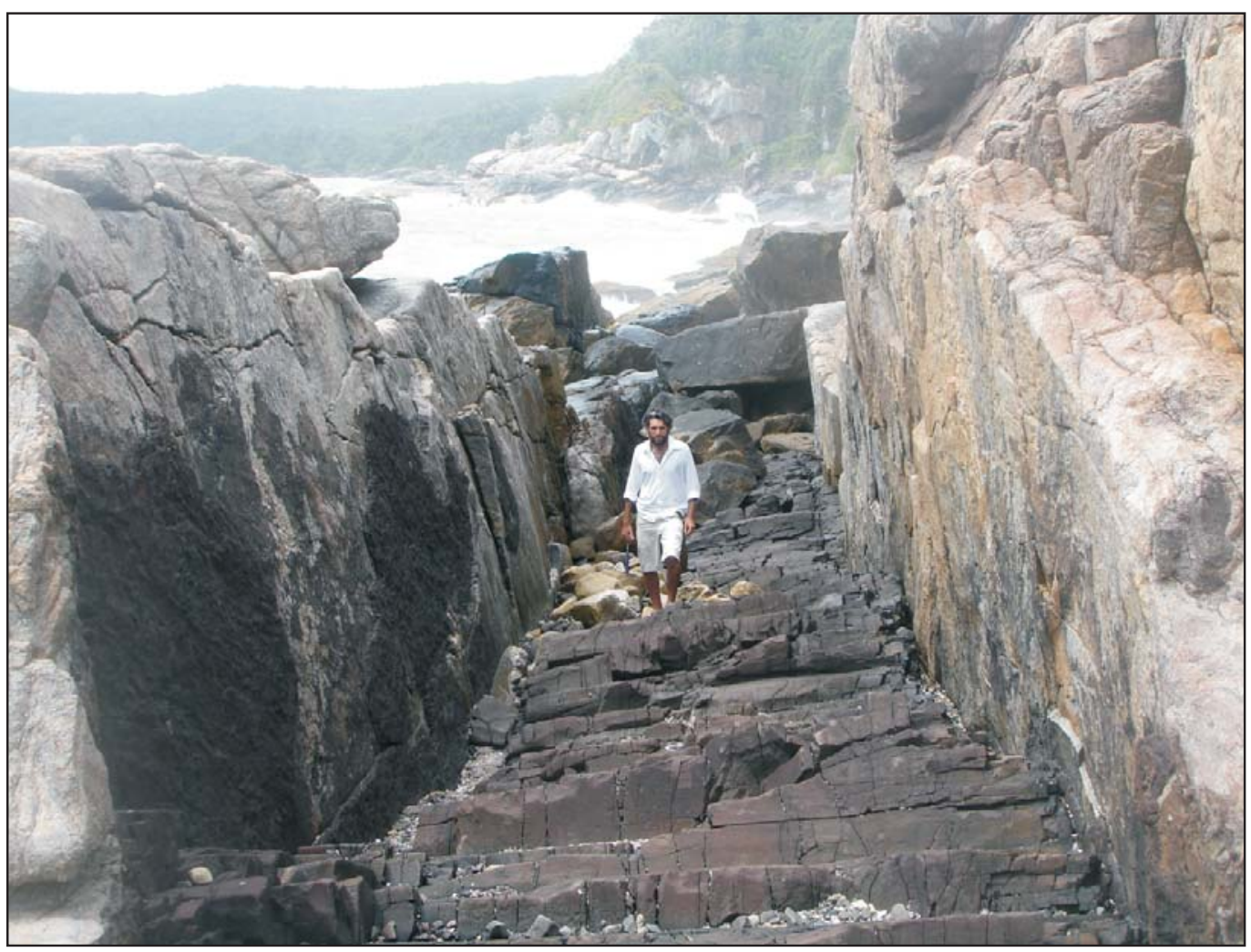

Foto 11 - Dique de diábásio com geometria retilínea. Ponta dos Zarlings, Bombinhas. A espessura do dique é de 3,om.

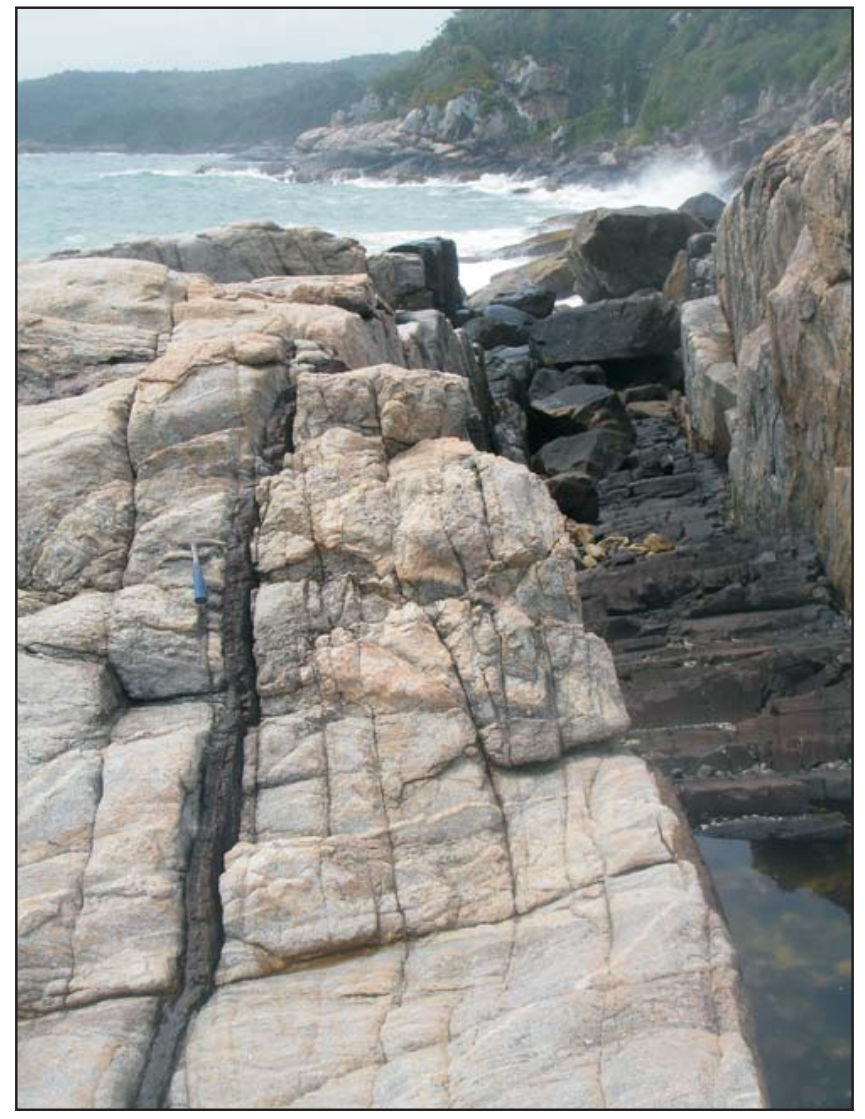

Foto 12 - Dique de diábásio com geometria retilínea. Ponta dos Zarlings, Bombinhas. A espessura do dique é de 3,om. 

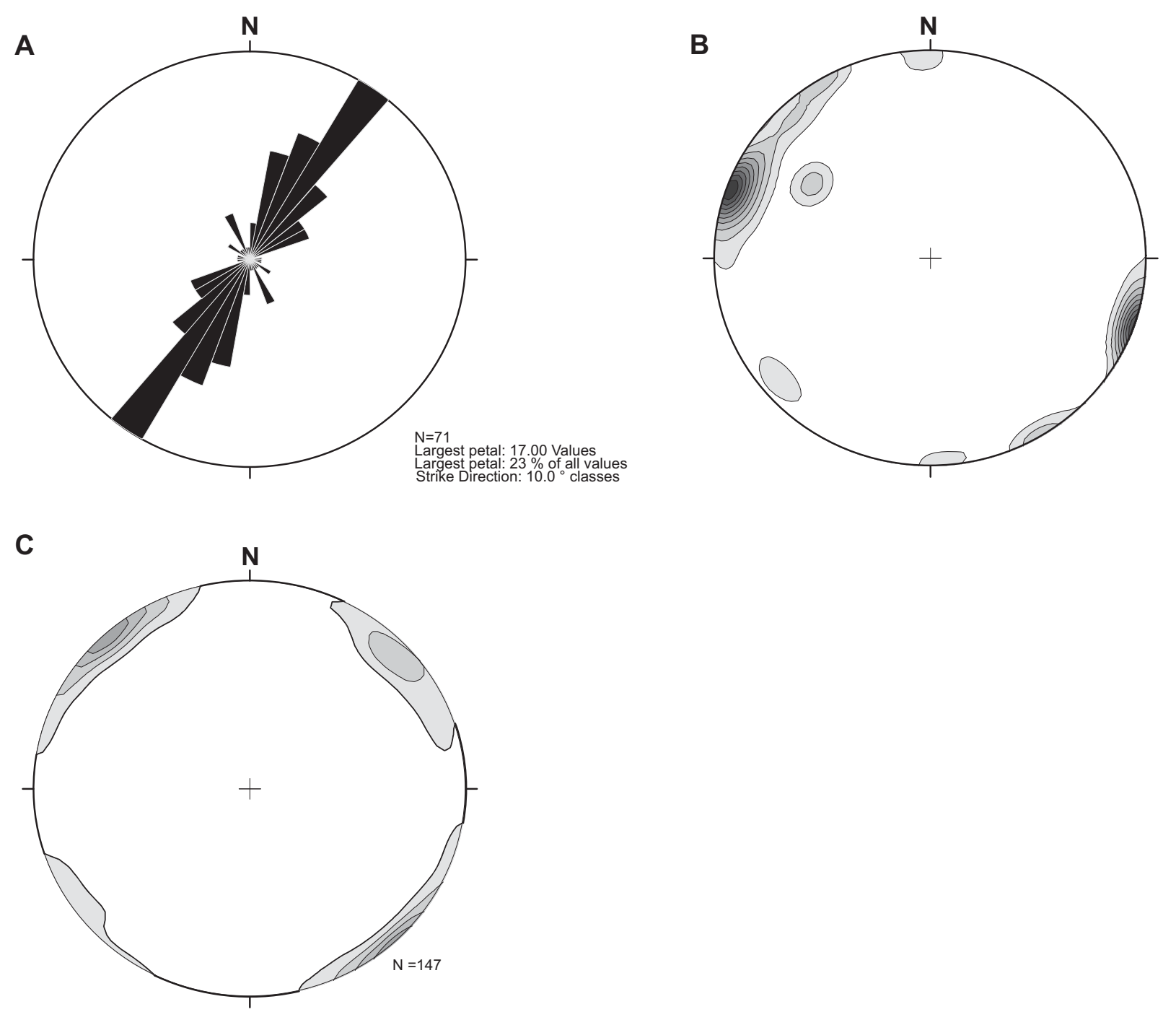

Figura 27 - A) Diagrama de rosácea representando 71 diques de diabásio entre Florianópolis e Imbituba. Dados obtidos nesta dissertação e compilados de Raposo (1998), Brentan (2006) e Tomazzoli \& Pellerin (2008). B) Diagrama de contorno da atitude dos diques indicando o predomínio de mergulhos subverticais. C) Diagrama de contornos de atitude de fraturas nas rochas encaixantes dos diques. Notar a presença de fraturas subparalelas à direção dos diques. 


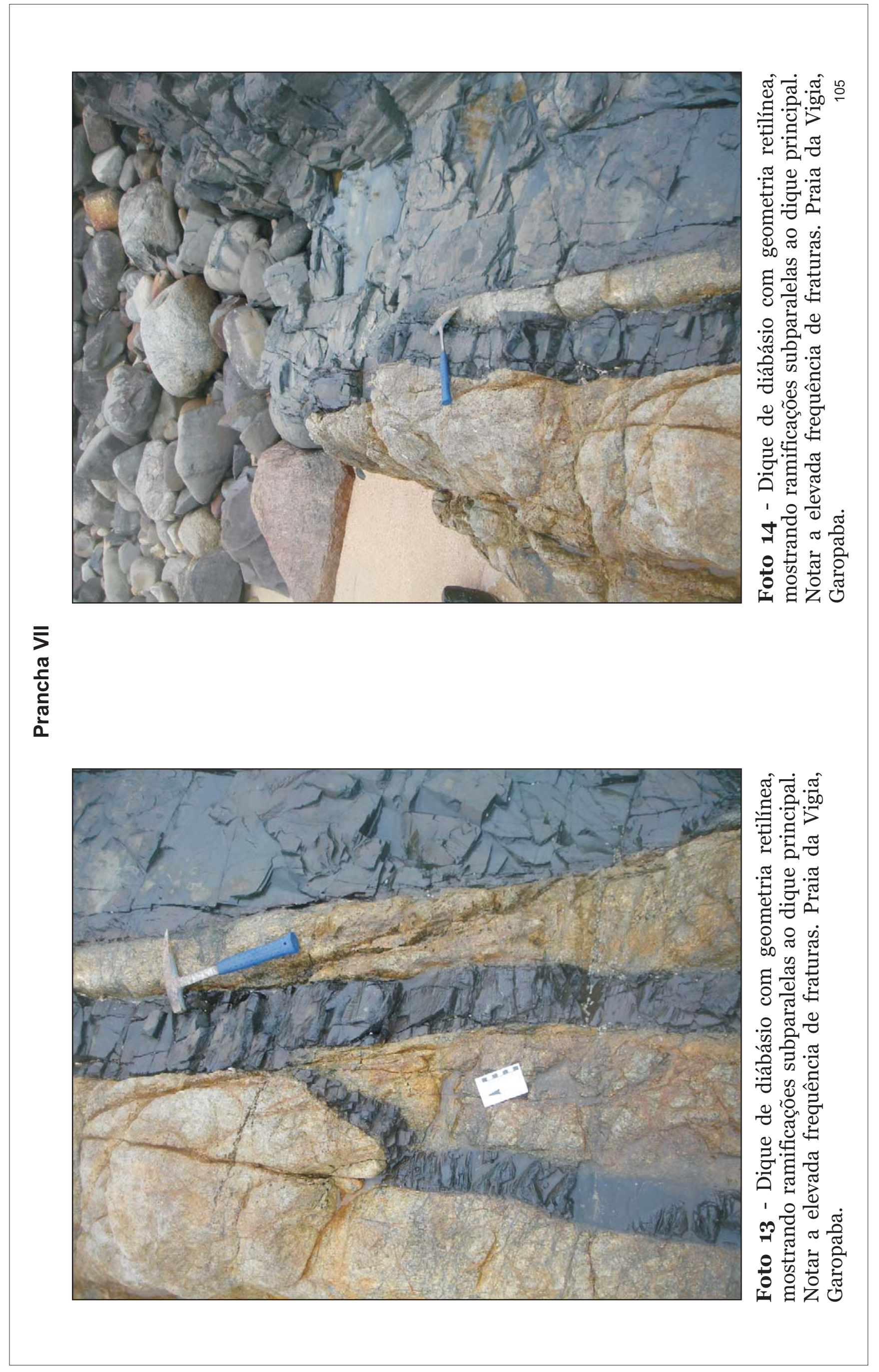




\section{Prancha VIII}

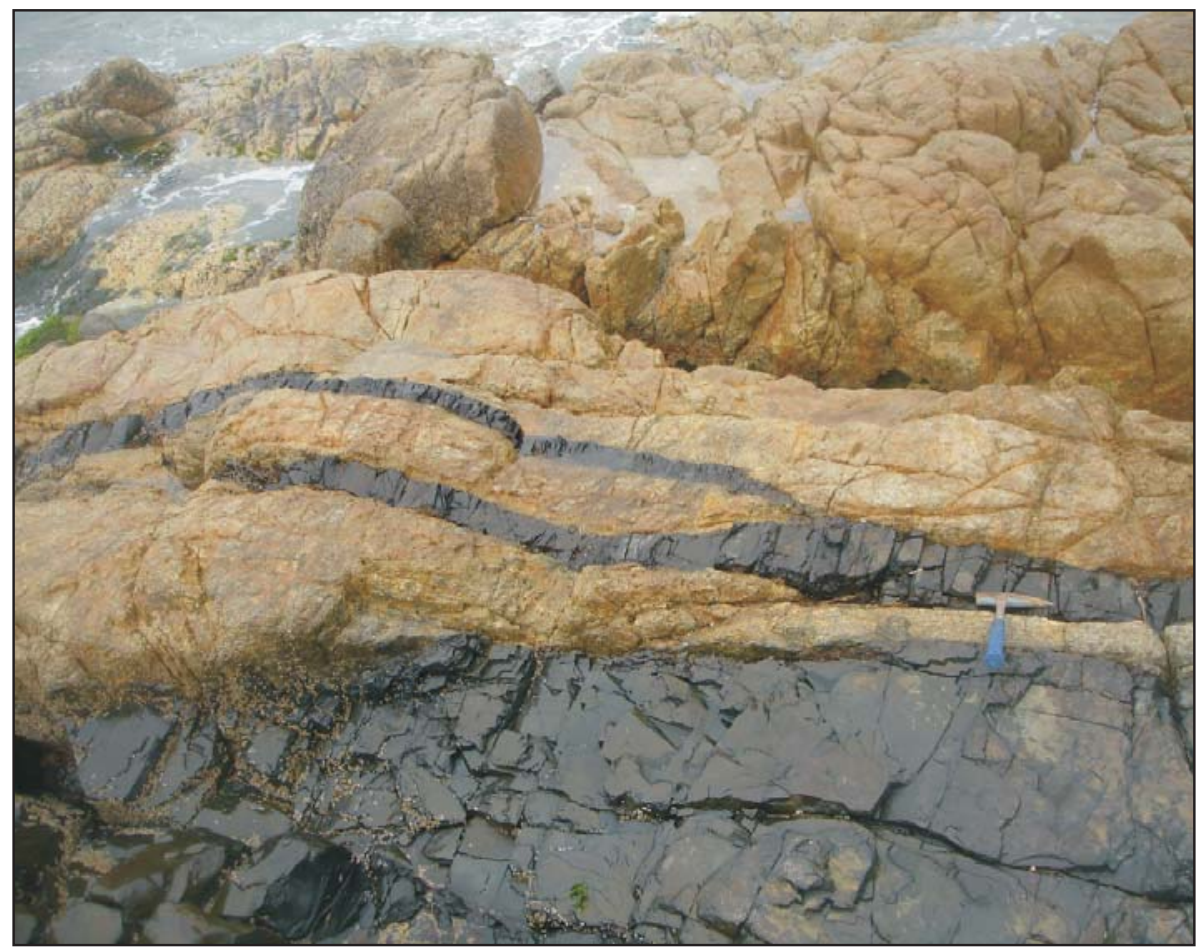

Foto 15 - Dique de diábásio com geometria retilínea e ramificações. Notar a elevada frequência de fraturas. Barra de Ibiraquera.

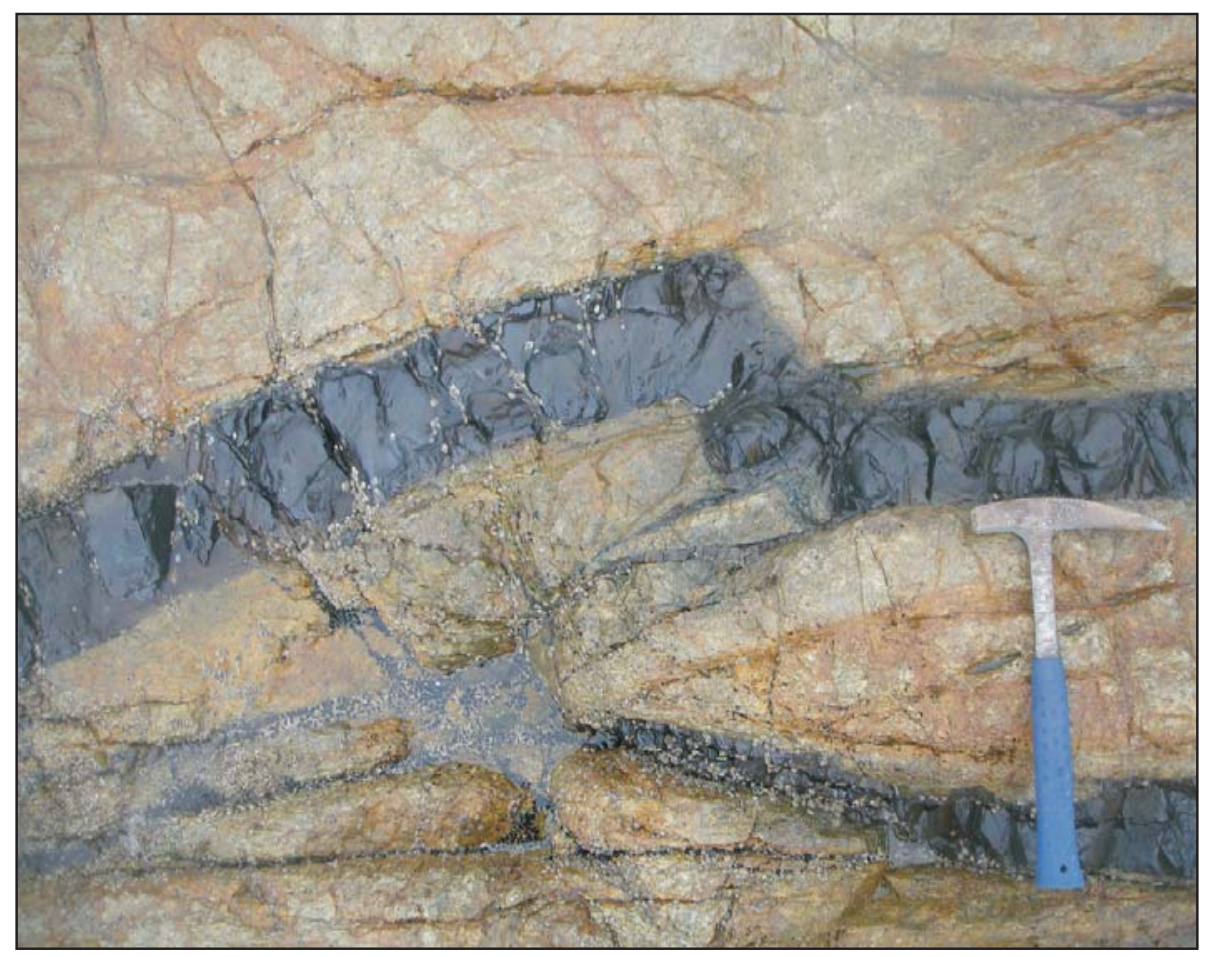

Foto 16 - Dique de diábásio com geometria segmentada . Notar a elevada frequência de fraturas. Barra de Ibiraquera. 


\section{Prancha IX}

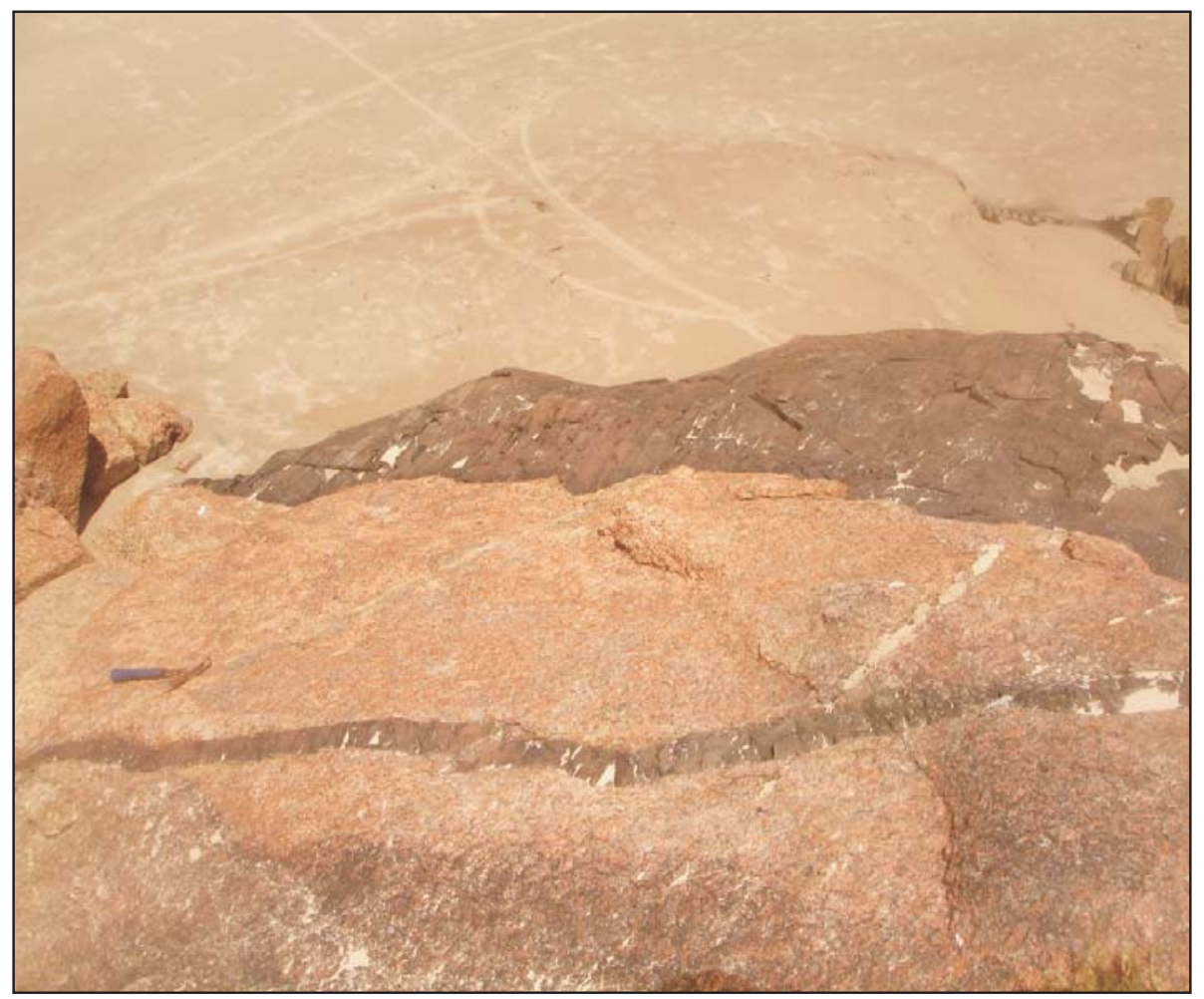

Foto 17 - Dique de diábásio com geometria retilínea, mostrando ramificações subparalelas ao dique principal. Notar a elevada frequência de fraturas. Barra de Ibiraquera.

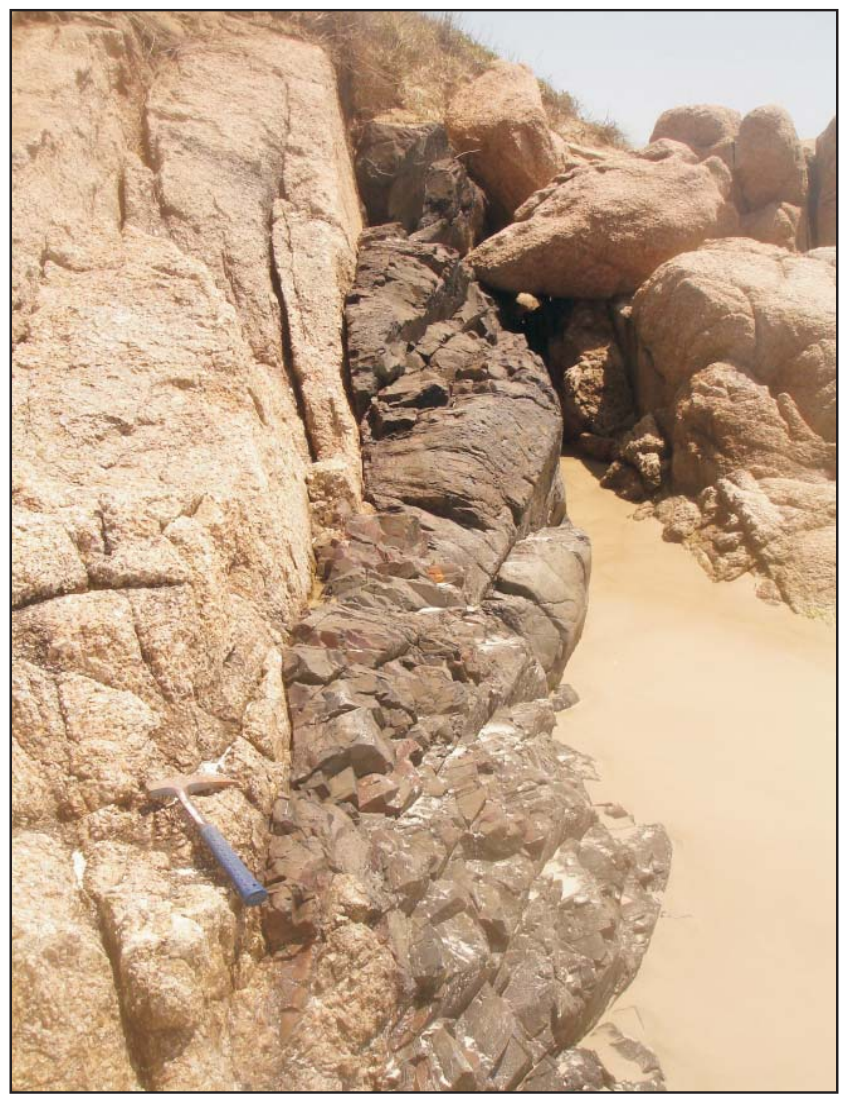

Foto 18 - Dique de diábásio com geometria retilínea. Notar a elevada frequência de fraturas. Barra de Ibiraquera. 


\subsubsection{Discussão sobre o Enxame de Florianópolis}

A direção preferencial dos diques entre N15E e N30E é persistente em todo Enxame de Florianópolis. De uma maneira geral, os diques estão organizados em um enxame linear paralelo às bordas do Rift Sul-Atlântico.

Os estudos realizados neste enxame indicaram o predomínio de diques com geometria retilínea, sugerindo que a abertura dessas fraturas (dilatação) ocorreu de acordo com os mecanismos de ruptura do Modo I (Pollard 1987). Dessa forma, podemos considerar que a formação/reativação de fraturas durante a intrusão desses diques ocorreu por processos de fraturamento hidráulico, conforme o modelo proposto em Delaney et al. (1986) e Jolly \& Sanderson (1995). A ocorrência de diques com terminações abruptas e ramificações é muito comum e foi interpretada como influência de fraturas pré-existentes durante o evento de intrusão.

A direção preferencial dos diques entre N15E e N30E indica que o esforço principal mínimo $(\sigma 3)$ variou entre N75E a N60E, paralelamente à direção de máximo estiramento crustal. 


\section{CONSIDERAÇÕES FINAIS SOBRE A DISSERTAÇÃO}

O intervalo de idade de geração do magmatismo Serra Geral ainda não está estabelecido. Aparentemente a melhor aproximação que se tem é representada por apenas 06 datações U-Pb. Esta sistemática isotópica mostrou-se a mais indicada ferramenta geocronológica para a resolução desta questão. No entanto, apenas com uma amostragem geográfica e estratigraficamente representativa, tanto dos derrames da Formação Serra Geral como dos enxames de diques, esta questão poderá avançar.

No caso dos enxames de diques, os dados geocronológicos existentes são insuficientes para o estabelecimento de relações cronológicas entre os diferentes enxames estudados. Se considerarmos as limitações interpretativas das sistemáticas isotópicas utilizadas, juntamente com dados paleomagnéticos, é possível considerar que os enxames de diques de Florianópolis, Ponta Grossa e Santos-Rio de Janeiro tenham se colocado em múltiplos episódios ao longo de um mesmo intervalo tempo.

Em relação ao uso de diques como indicadores tectônicos, estes não são suficientes para definir o regime de esforços durante a intrusão na crosta. Enxames de diques lineares são bons indicadores da direção do esforço principal mínimo ( $\sigma 3$ ou $\mathrm{SH}_{\text {min }}$ ), uma vez que estes corpos tendem a se colocarem perpendicularmente a esta direção, aproveitando estruturas pré-existentes (Figura 28).

Dessa forma, os estudos estruturais desenvolvidos nesta dissertação demonstram que o Enxame de Diques Santos-Rio de Janeiro, de direção geral NE-SW, se alojou na crosta em um regime tectônico onde o esforço principal mínimo $(\sigma 3)$ estava orientado na direção geral NW-SE, horizontal. Os diques do Enxame de Ponta Grossa, ao contrário, apresentam direção geral NW-SE e se alojaram na crosta durante a vigência de um regime tectônico, onde o esforço principal mínimo estava orientado na direção geral NE-SW. No caso do Enxame de Florianópolis, estes apresentam direção geral NNE-SSW e se alojaram na crosta durante a vigência de um regime tectônico com o esforço principal mínimo horizontal e orientado na direção WNW-ENE (Figura 29). 

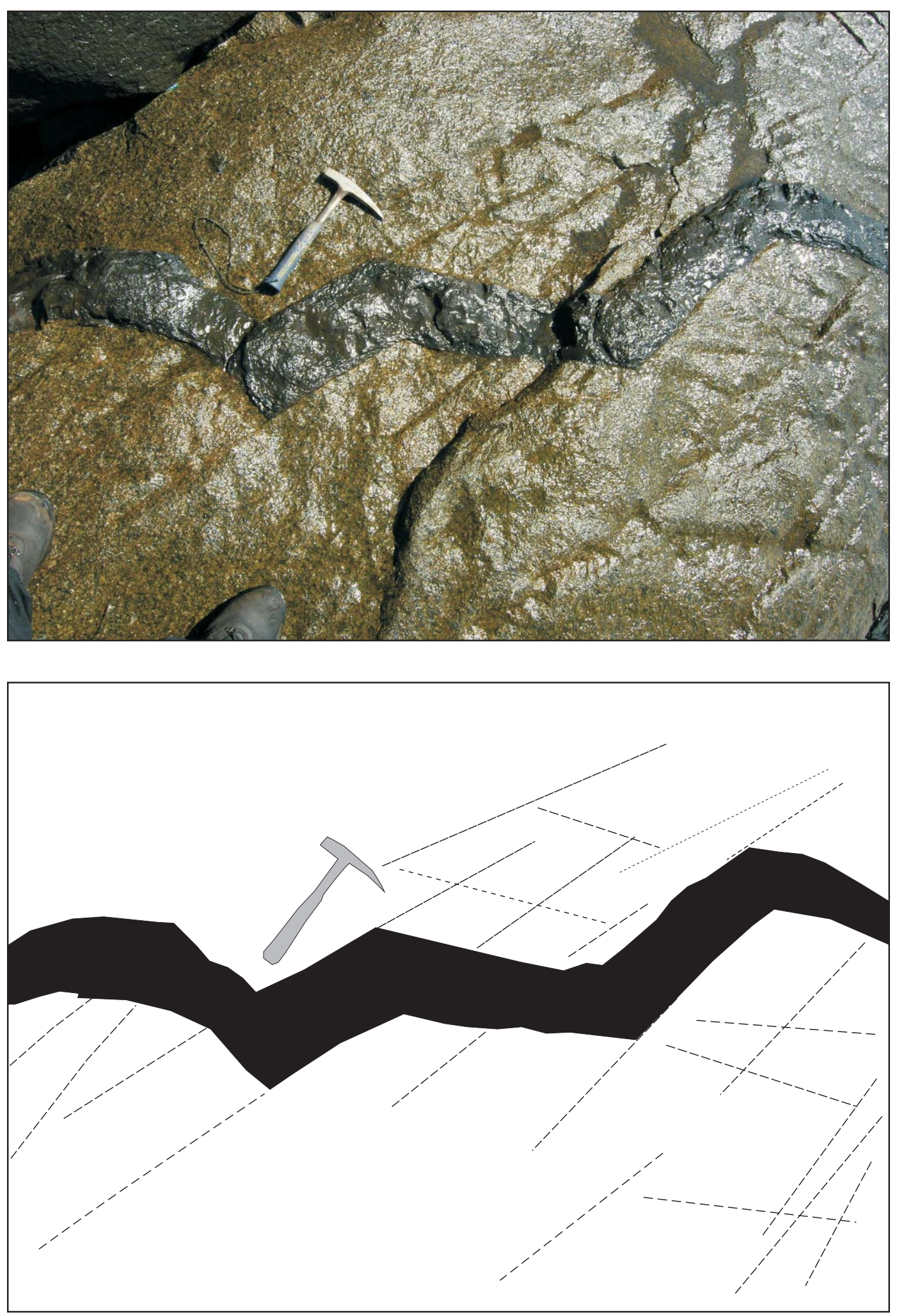

Figura 28 - Dique segmentado em zig-zag mostrando sua relação com as fraturas da rocha encaixante. Notar que as mudanças abruptas de direção está sempre associada à presença de uma fratura. As fraturas não cortam o dique, ao contrário, são cortadas por ele sem apresentar deslocamento aparente. Este fato implica que as fraturas são anteriores ao dique indicando um exemplo de dilation intrusion. Praia do Campeche Florianópolis. Foto: Claudio Riccomini. 


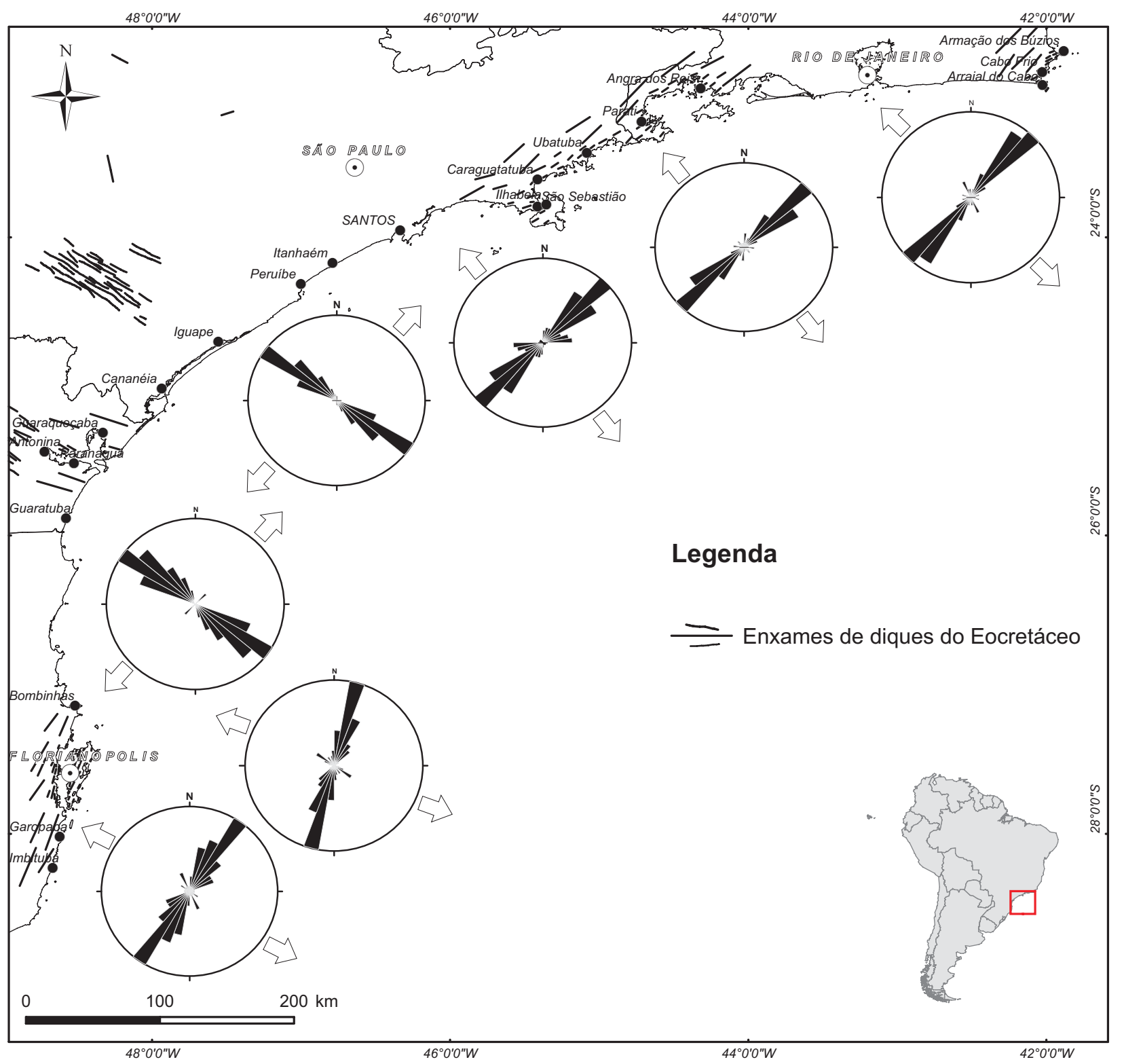

Figura 29 - Distribuição regional dos enxames de diques máficos eocretaceos do SulSudeste do Brasil. As setas brancas indicam a direção do esforço principal mínimo ( $\sigma 3)$.Diagramas de rosácea realizados com dados obtidos neste trabalho e compilados de Damasceno (1966), Pinese (1989), Garda (1995), Silva \& Riccomini (2005), Tomba \& Sato (2006), Brentan (2006) e Coutinho (2008). 
Os enxames da Serra do Mar e Florianópolis estão localizados nas bordas do Rift Sul-Atlântico, enquanto que o Enxame de Ponta Grossa é transversal às suas estruturas, situação semelhante à descrita por Mége \& Korme (2004) para os enxames de diques relacionados à Província Basáltica da Etiópia. Demonstrando que em regiões sujeitas à distensão crustal, enxames de diques são excelentes indicadores da direção de estiramento e tendem a se concentrar paralelamente e transversalmente às bordas de rifts.

A revisão histórica dos conhecimentos acumulados sobre os enxames de diques evidenciam que os assuntos discutidos no presente trabalho já estavam fartamente descritos, discutidos e interpretados em trabalhos anteriores. A extensão e polaridade do magmatismo Serra Geral, bem como a correlação desta unidade com as rochas vulcânicas das bacias marginais, foi proposta demonstrada nos trabalhos clássicos de Almeida (1976) "The system of continental rifts bordering the Santos Basin, Brazil" e em Almeida et al (1996) no trabalho "Correlação do magmatismo das bacias da margem continental brasileira com o das áreas emersas adjacentes".

Do ponto de vista da análise estrutural dos enxames de diques, o trabalho de Damasceno (1966) "Estudo Preliminar dos Diques de Rochas Básicas e Ultrabásicas da Região de Ubatuba, Estado de São Paulo" deve ser considerado pioneiro no assunto, inclusive internacionalmente. Neste trabalho, o autor demonstrou de forma clara que os diques máficos eocretaceos da região de Ubatuba, no litoral norte do Estado de São Paulo, aproveitaram preferencialmente fraturas pré-existentes durante a intrusão na crosta.

Em relação ao mapeamento e caracterização litológica e petrográfica dessas rochas, a maior contribuição deve-se a diversos trabalhos publicados pelo Prof. José Moacyr Vianna Coutinho desde a década de 1960 e sintetizados em Coutinho (2008): "Dyke Swarms of the Paraná Triple Junction, Southern Brazil", guia dessa dissertação.

As pesquisas realizadas nesta dissertação confirmam tudo que estes autores defenderam em seus trabalhos, e tornam reduzida nossa contribuição frente ao pioneirismo e alto nível dos trabalhos precedentes. 


\section{1- Referências Bibliográficas}

Alagarte J.P. (1972) A influência dos arqueamentos cratônicos no condicionamento das alcalinas nos estados de São Paulo e Paraná. In: 26 Congresso Brasileiro de Geologia, Belém, Resumos, (2): 65-69.

Almeida F.F.M. (1967) Origem e evolução da plataforma brasileira. Rio de Janeiro: DNPM/DGM, Boletim 241, 36 pp.

Almeida F.F.M. (1969) Diferenciação tectônica da plataforma brasileira. In: $22^{\circ}$ Congresso Brasileiro de Geologia, Salvador, Resumos, (1): 29-46.

Almeida F.F.M. (1972) Tectono-magmatic activation of the South American Platform and associated mineralization. 24th International. Geological Congress, Anaes (3): 339-346.

Almeida F.F.M. (1976). The system of continental rifts bordering the Santos Basin, Brazil. In: International Symposium on continental margins of Atlantic type, São Paulo, 1975. Anais da Academia Brasileira de Ciências 48:15-26.

Almeida F.F.M. (1986). Distribuição regional e relações tectônicas do magmatismo pós-Paleozoico no Brasil. Revista Brasileira de Geociências. 16: 325-349.

Almeida F.F.M. (1983) Relações tectônicas das rochas alcalinas mesozoicas da regiao meridional da plataforma sul-americana. Revista Brasileira de Geociências. 3: 139-158.

Almeida F.F.M., Carneiro C.D.R., Mizusaki A.M.P. (1996) Correlação do magmatismo das bacias da margem continental brasileira com o das áreas emersas adjacentes. Revista Brasileira de Geociências. 26 (3): $125-138$.

Almeida F.F.M. \& Carneiro C.D.R. (1998). Origem e evolução da Serra do Mar. Revista Brasileira de Geociências. 28 (2): 135-150.

Almeida F.F.M., Neves B.B.B., Carneiro C.D.R.D. (2000) The origin and evolution of the South American Platform. Earth Science Reviews 50: 77- 111.

Almeida R.P., Janikian L., Fragoso-Cesar A.R.S., Fambrini G. (2010) The Ediacaran to Cambrian Rift System of Southeastern South America: Tectonic Implications. The Journal of Geology 118: 145-161.

Almeida T.I.R. (1982) O Arco de ponta Grossa: uma proposta para sua configuração e gênese a partir da interpretação de dados de sensoriamento remoto. Dissertação de mestrado. Instituto Nacional de Pesquisas Espaciais, INPE.

Amaral G., Cordani U.G., Kawashita K., Reynolds J.H. (1966) Potassium-argon dates of basaltìc rocks from southerm Brazil. Geochimica. Cosmochimica. Acta 30:159-189.

Anderson E.M. (1951) The dynamics of faulting and dyke formation with application to Britain: Edinburgh. Oliver and Boyd Ltd., 206 p.

Anderson D.L. (1967) Phase changes in the upper mantle. Science 157: 1165-1173.

Anderson D.L. (1970) Velocity-density relations. Journal of Geophysical Research 84: 1623-1624.

Anderson D.L., Tanimoto T., Zhang Y.S. (1992) Plate tectonics and hotspots- The 3rd dimension. Science 256: 1645-1651.

Anderson D.L. (1995) Lithosphere, astenosphere and perisphere: Reviews of Geophysics 33: 125-149.

Anderson D.L. (1998) The edges of the mantle. In: Gurnis M., Wysession M.E, Knittle E., Buffett B.A. (Eds.). The Core-Mantle Boundary Region. Geodynamics Series Vol. 28: 255-271. 
Anderson D.L. $\left(2005^{\mathrm{a}}\right)$ Scoring hotspots: The plume and plate paradigms In: Foulger G.R., Natland, J.H., Presnall D.C., Anderson D.L. (Eds.) Plates, plumes and paradigms, Geological Society of America Special Paper, 388, p. 31-54

Anderson D.L. $\left(2005^{\mathrm{b}}\right)$ Self-gravity, self-consistency, and self-organization in geodynamics and geochemistry. In: van der Hilst R.D., Bass J., Matas J., Trampert J. (Eds.) Earth's Deep Mantle: Structure, Composition, and Evolution, American Geophysical Union Monograph Series 160: 165-186.

Anderson D.L., Schramm K.A. (2005) Global Hotspot Maps. In: Foulger G.R., Natland, J.H., Presnall D.C., Anderson D.L. (Eds.) Plates, plumes and paradigms, Geological Society of America Special Paper, 388 , p. $19-29$.

Ardnt N. \& Christensen N. (1992) The role of lithospheric mantle in continental flood volcanism: Thermal and geochemical constraints. Journal of Geophysical Research 97: 10967-10981.

Asmus H.E. \& Porto R. (1972) Classificação das bacias sedimentares brasileiras segundo a tectônica das placas. In: $2^{\circ}$ Congresso Brasileiro de Geologia, Belém, Resumos, (2): 67-90.

Asmus H.E. \& Ponte F.C. (1973) The Brazilian marginal basins. In: Naim A.E.M. \& Stehli F.G. (Eds.) The Ocean Basins and Margins, Vol. I. The South Atlantic. Plenum Press, New York, N.Y., pp. 87-133.

Asmus H.E. (1975) Controle estrutural da deposição mesozoica nas bacias da margem continental brasileira. Revista Brasileira de Geociências 5: 160-175

Asmus H.E. \& Porto R. (1980) Diferenças nos estágios iniciais da evolução tectônica da margem continental leste Brasileira: possíveis causas e implicações. In: $31^{\circ}$ Congresso Brasileiro de Geologia, Camboriú, Resumos, (1): 225-239.

Asmus H.E. \& Guazelli M. (1981) Descrição sumária das estruturas da margem continental brasileira e das áreas oceânicas e continentais adjacentes, hipóteses sobre o tectonismo causador e implicações para os prognósticos de recursos minerais. In: (Projeto REMAC 9). Estruturas e tectonismo da margem continental brasileira, e suas implicações nos processos sedimentares e na avaliação do potencial de recursos minerais. Relatório Final. PETROBRAS/CENPES/DINTEP. p.187-269.

Aslanian D., Moulin M., Olivet J.L., Unternehr P. Matias L., Bache F., Rabineau M., Nouzé H., Klingelheofer F., Contrucci I., Labails C. (2009) Brazilian and African passive margins of the Central Segment of the South Atlantic Ocean: Kinematic constraints. Tectonophysics 468 (1): 98-112.

Atkinson B.K. (1987) Fracture Mechanics of Rock Academic Press, London. 380p.

Baer G. \& Reches Z. (1987). Flow patterns of magma in dikes, Makhtesh Romon, Israel. Geology 15: $569-572$.

Baer G., Beyth M., Reches Z. (1994) Dikes emplaced into fractured basement, Timna Igneous Complex, Israel. Journal of Geophysical Research 99(B12): 0148-0227.

Baer G. \& Beyth M. (1990) A mechanism of dyke segmentation in fractured host rock. In: Mafic Dykes and Emplacement Mechanisms. Parker A.J. \& Rickwood P.C. (Eds.) Balkema, Rotterdam, p. 3-11.

Bahar I. \& Girod M. (1983) Controle Structural du Vulcanisme Indonesien (Sumatra, Java, Bali): application et critique de la methode de Nakamura. Bulletin de la Societe Geologique de France 4: 609614.

Baksi A. K. (2005) Radiometric ages of hotspot rocks in and around the Atlantic, Indian and Pacific Oceans. In: Foulger G.R., Natland, J.H., Presnall D.C., Anderson D.L. (Eds.) Plates, plumes and paradigms, Geological Society of America Special Paper, 388, p. 57-70.

Barton A.J. \& White R.S. (1997) Crustal structure of the Edoras Bank continental margin and mantle thermal anomalies beneath the North Atlantic, Journal of Geophysical Research 102: 3109-3129. 
Basseto M., Alkimim F.F., Szatmari P., Mohriak W.U. (2000) The oceanic Segment of the Southern Brazilian Margin: Morpho-Structural Domains and their Tectonic Significance. In: Mohriak W.U. \& Talwani M. (Eds.) Atlantic Rifts and Continental Margins American Geophysical Union Monography 115: 212-235.

Becaluva L., Campredon R., Féraud G., Macciotta G. (1983) Étude des relation entre volcanisme plioquaternaire et tectonique en Sardaigne a l'aide de l'analyse structurale des dykes. Bulletin of Volcanology 46: 365-379.

Behn M.D.\& Ito G. (2008) Magmatic and tectonic extension at mid-ocean ridges: 1. Controls on fault characteristics, Geochemistry, Geophysics, Geosystem 9.

Bellieni G., Comin-Chiaramonti P., Marques L.S., Melfi A.J., Nardy A.J.R., Piccirillo E.M., Stolfa D., Roisemberg A. (1984) High- and low- $\mathrm{TiO}_{2}$ flood basalts from the Paraná plateau (Brazil): petrology and geochemical aspects bearing on their mantle origin. Neues Jahrbuch Mineralogische Abhandlungen 150: 273-306

Bellieni G., Comin-Chiaramonti P.C., Marques L.S., Melfi A.J., Nardy A.J.R., Papatrechas C., Piccirillo E.M., Roisenberg A. (1986) Petrogenetic aspects of acid and basaltic lavas from the Parana plateau (Brazil): geological, mineralogical and petrochemical relationships. Journal of Petrology 27: 915-944.

Benini S. (1992) Sciami di dicchi nel S-E Brasile: petrologia, geochimica isotopica e implicazioni geodinamiche. Trieste. 123 p. (Tese de Doutorado, Intituto de Mineralogia e Petrografia da Universidade deTrieste, Itália).

Berger A.R. (1971) Dynamic Analysis Using Dikes with Oblique Internal Foliations. Geology 82 (3): 781-786.

Best M.G. (1988) Early Miocene change in direction of least principal stress, southwestern United States: Conflicting inferences from dikes and metamorphic core detachment fault terranes. Tectonics 7: 249-259.

Beutel E.K., Nomade S., Fronabarger A.K., Renne P.R. (2005) Pangaea's complex breakup: a new rapidly changing stress field model. Earth Planetary Science Letters 236: 471-485.

Beutel E. (2009) Magmatic rifting of Pangaea linked to onset of South American plate motion. Tectonophysics 468: 149-157.

Billings M. P. (1972) Structural Geology. Prentice-Hall Inc. Englewood Cliffs, New Jersey, USA. 606 p.

Bitencourt M.F., Hackspacher P.C., Stoll L.V. (1989) A Zona de Cisalhamento Major Gercino - Santa Catarina. In: $2^{\circ}$ Simpósio Nacional de Estudos Tectônicos, Fortaleza, Resumos, pág. 214-215.

Bossi J., Campal N., Civetta L., Girardi V.A.V., Mazzuchelli M., Negrini L., Rivalenti G., Fragoso-Cesar A.R.S., Sinigoi S., Teixeira W., Piccirillo E.M., Molesini M. (1993). Early Proterozoic dike swarms from western Uruguay: geochemistry, Sr-Nd isotopes and petrogenesis. Chemical Geology 106(3-4): 263-277.

Bosworth W., K. Burke, M. Strecker (2000) Magma chamber elongation as an indicator of intraplate stress field orientation: Borehole breakout mechanism and examples from the Late Pleistocene to Recent Kenya Rift Valley. In: Jessell M.V. \& Urai J.L. (Eds.) Stress, Strain, and Structure, A Volume in Honor of W.D. Means. Journal of Virtual Explorer 2.

Bott M.H.P. (1971) The Interior of the Earth. London: Edward Arnold.

Brentan S. (2006) Determinação do regime tectônico de colocação do enxame de diques de Florianópolis, Santa Catarina. Brasil. Trabalho de Conclusão de Curso. Instituto de Geociências,Universidade de São Paulo.50p. 
Bryan S.E., Ewart A., Stephens C.J., Parianos J., Downes P.J. (2000) The Whitsunday volcanic province, central Queensland, Australia: Lithologic and stratigraphic investigations of a silicic-dominated large igneous province. Journal of Volcanology and Geothermal Resarch 99: 55-78.

Bryan S. \& Ernst R.E. (2007) Revised definition of Large Igneous Provinces (LIPs). Earth-Science Reviews 86(1-4): 175-202.

Buck W. R. (2006) The role of magma in the development of the Afro-Arabian rift system. In: Yirgu G., Ebinger C.J., Maguire P.K.H. (Eds). The Afar Volcanic Province within the East African Rift System. Geological Society, London, Special Publications, 259: 43-54.

Bueno G.V., ZachariasA.A., Oreiro S.G., Cupertino J.A., Falkenhein F.U.H., Neto M.A. (2007) Bacia de Pelotas. Boletim de Geociências da Petrobras15 (2): 551-559.

Bueno G.V. (2004) Diacronismo de eventos no rifte Sul-Atlântico. Boletim de Geociências da Petrobrás 12 (2): 203-229.

Bullard E. C., Everett J.E., Smith A.J. (1965). The fit of the continents around the Atlantic. In: Blackett P.M.S., Bullard E.C., Runcorn S.K. (Eds.). A Symposium on Continental Drift. Philosophical. Transactions. Royal. Society of London, A258:41-51.

Burke K. \& Dewey J.F. (1973) Plume generated triple junctions: key indicators in applying plate tectonics to old rocks. The Journal of Geology 1: 406-433.

Bussel M. A. (1989) A simple method for the determination of the dilation direction of intrusive sheets. Journal of Structural Geology 11: 679-687.

Cainelli C. \& Mohriak W. U. (1998) Geology of Atlantic Eastern Brazilian Basins: American Association of Petroleum Geologists. International Conference and Exhibition Rio de Janeiro, Short Course on Brazilian Geology, Part II.

Campbell I.H. (2005) Large igneous provinces and the mantle plume hypothesis:

Element 1: 265-269.

Cañón-Tapia E. (2008) How deep can be a dyke? Journal of Volcanology and Geothermal Research 171: $215-228$.

Carlson R.W. (1992) Flood basalts: Melting a wet source. Nature 358: 20-21.

Chang H.K. \& Kowsmann R.O. (1984). Subsidência térmica e espessura crustal da Bacia de Santos. In: $33^{\circ}$ Congresso Brasileiro de Geologia, Rio de Janeiro, Resumos, (4): 1602-1614.

Chang H.K., Kowsmann R.O., Figueiredo A.M.F. (1988). New concepts on the development of East Brazilian marginal basins. Episodes 11, 194-202.

Chang H.K., Kowsmann R.O., Figueiredo A.M.F., Bender A.A. (1992). Tectonics and stratigraphy of the East Brazil rift system. Tectonophysics 213 (1): 97-138.

Coffin M.F. \& Eldholm O. (1992) Volcanism and continental break-up: a global compilation of large igneous provinces. In: B.C. Storey, T. Alabaster and R.J. Pankhurst (Editors), Magmatism and the Causes of Continental Breakup. Special Publication of the Geological Society of London, London, pp. 17-30.

Coffin M.F. \& Eldholm O. (1993) Scratching the surface: estimating dimensions of large igneous provinces. Geology 21: 515-518.

Coffin M.F. \& Eldholm O. (1994) Large igneous provinces: crustal structure, dimensions, and external consequences. Reviews of Geophysics 32(1): 1-36. 
Comin-Chiaramonti P., Riccomini C., Slejko F., De Min A., Ruberti E., Gome C.B. (2010) Cordieritebearing lavas from Jaguarão, southern Brazil: Petrological evidence for crustal melts during early rifting of Gondwana. Gondwana Research 18(2-3): 514-527.

Comin-Chiaramonti P., Gomes C.B., Piccirillo E.M., Rivalenti G. (1983) High-TiO2 basaltic dykes in the coastline of São Paulo and Rio de Janeiro states (Brazil). Neus. Jahr. Miner. Abh. 146: 133-150.

Correa-Gomes L.C., Souza Filho C.R., Martins C.J.F.N., Oliveira E.P. (2001) Development of symmetrical and asymmetrical fabrics in sheet-like igneous bodies: the role of magma flow and wall rock displacements in theoretical and natural cases. Journal of Structural Geology 23: 1415-1428.

Correa da Costa P. C., Girardi V.A.V., Teixeira W. (2006) ${ }^{40} \mathrm{Ar} /{ }^{39} \mathrm{Ar}$ geochronology of the Goiás-Crixás dyke swarm, Central Brazil: further evidence of the neoarchean-paleoproterozoic tectonic boundary in South America and Nd-Sr signature of the subcontinental mantle throughout time. International Geology Review 48: 547-560.

Corrêa Gomes L.C., Oliveira M.A.F., Motta A.C., Cruz M.J.M. (1996) Província de Diques Máficos do Estado da Bahia. Mapa, estágio atual do conhecimento e evolução temporal. SICM/SGM, Salvador (Edição Especial), 144p.

Courtillot V., Jaupart C. Manighetti P., Taponier P., Besse J. (1999) On causal links between flood basalts and continental breakup. Earth Planetary Science Letters 166: 177-195.

Courtillot V., Davaille A., Besse J., Stock J. (2003) Three distinct types of hotspots in the Earth mantle. Earth and Planetary Science Letters 205: 295-308.

Coutinho J.M.V. (2005) Dyke swarms of the Paraná triple junction. In: Vuollo J. \& Mertanen S. (Eds.). "Dyke swarms - time markers of crustal evolution". 5st International Dyke Conference. Finland.

Coutinho J.M.V. (2008) Dyke Swarms of the Paraná Triple Junction, Southern Brazil. Geologia USP: Série Científica 8 (2): 29-52.

CPRM (2004) Carta Geológica do Brasil ao Milionésimo, Sistema de Informações Geográficas. Programa Geologia do Brasil. CPRM, Brasília. 2004. CD-ROM.

Currie K.L. \& Ferguson J. (1970) The mechanism of intrusion of lamprophyre dikes indicated by offsetting of dikes. Tectonophysics 9: 525-535.

Curie D. (1984) Ouverture de l'Atlantique sud et discontinuités intra-plaque: une nouvelle analyse. Universitéde Bretagne Occidentale. Brest.192 pp.

D'agrella-Filho M. S., Pacca I.I.G., Trindade R.I.F., Teixeira W., Raposo M.I.B., Onstott T.C. (2004) Paleomagnetism and ${ }^{40} \mathrm{Ar}^{39} \mathrm{Ar}$ ages of mafic dykes from Salvador (Brazil): new constraints on the São Francisco Craton APW path between 1080 and 1010 Ma. Precambrian Research 132: 55-77.

Damasceno E.C. (1966) Estudo preliminar dos diques de rochas básicas e ultrabásicas da região de Ubatuba, Estado de São Paulo. Anais da Academia Brasileira de Ciências. 38 (2): 293-304.

Deckart K., Feraud G., Marques L.S., Bertrand H. (1998) New time constraints on dyke swarms related to the Parana-Etendeka magmatic province, and subsequent South Atlantic opening, southeastern Brazil. Jounal of Volcanology and Geothermal Research 80: 67-83.

Delaney P.T. \& Pollard D.D. (1981) Deformation of Host Rocks and Flow of Magma During Growth of Minette Dikes and Breccia-bearing Intrusions Near Ship Rock, New Mexico, Professional Paper, 1202. United States Geological Survey, Washington. 61 p.

Delaney P.T., Pollard D.D., Ziony J.I., McKee E.H. (1986) Field relations between dikes and joints: emplacement processes and paleostress analysis. Journal of Geophysical Research 91: 4920-4938. 
Denyszyn S.W., Halls H.C., Davis D.W. (2006) A paleomagnetic, geochemical and U-Pb geochronological comparison of the Thule (Greenland) and Devon Island (Canada) Dyke swarms and its relevance to the nares strait problem. Polarforschung 74(1-3): 6375.

Deuss A., Redfern S.A.T., Chambers K., Woodhouse J.H. (2006) The nature of the $660 \mathrm{~km}$ discontinuity in earth's mantle from global seismic observations of PP precursors. Science 311: 198-201.

Dias J.L., Sad A.R.E., Fontana R.L., Feijó F.J. (1994) Bacia de Pelotas. Boletim de Geociências da Petrobras 8: 235-245.

Dias J.L., Scarton J.C., Esteves F.R, Carminatti M., Guardado L.R. (1990) Aspectos da evolução sedimentar e a ocorrência de hidrocarbonetos na Bacia de Campos. In: Rajagabaglia G.P. \& Milani E.J. (Eds.). Origem e Evolução de Bacias Sedimentares. Rio de Janeiro. Petrobras,p. 333-360.

Dickin A.P. (1997) Radiogenic Isotope Geology. Cambridge University Press. 490pp

Dietz R.S. (1961) Continent and Ocean Basin Evolution by Spreading of the Sea Floor. Nature 190: 854857.

Dilek Y., Moores E., Elthon D., Nicolas A. (2000) Ophiolites and Oceanic Crust: New Insights from Field Studies and the Ocean Drilling Program. Proceedings of the Penrose Conference.Geological Society of America Special Paper no. 349. 552 pp.

Dutra T. (2006) Petrogênese dos basaltos de baixo-TiO2 do Enxame de Dique da Serra do Mar na Região dos Lagos, RJ. Dissertação de mestrado. Universidade do Estado do Rio de Janeiro. 111pp.

Dutra T, Valente S., Heilbron M., Corval A., Szatmari P. (2008) Litogeoquímica preliminar do Enxame de diques da Faixa de Colatina. In: IV Simpósio de Vulcanismo e Ambientes Associados, Foz do Iguaçu. v. CD-ROM.

Eagles G. (2007) New angles on South Atlantic opening. Geophysical Journal International 168: 353-361.

Eawart A. Schön R.W., Chappell B.W. (1992) The Cretaceous volcanic-plutonic province of the central Queensland (Australia) coast - a rift related "calc-alkaline" province. Transaction of the Royal Society of Edinburgh. Earth Sciences 83: 327-345.

Ewart A., Marsh J.S., Milner S.C., Duncan A.R., Kamber B.S., Armstrong R.A. (2004) Petrology and geochemistry of Early Cretaceous bimodal continental flood volcanism of NW Etendeka, Namibia. Part I: Introduction, mafic lavas and re evaluation of mantle source components. Journal of Petrology 45(1): 59105.

Erlank A.J., Marsh J.S., Duncan A.R., Miller R.McG., Hawkesworth C.J., Betton P.J., Rex D.C. (1984) Geochemistry and petrogenesis of the Etendeka volcanic rocks from South West Africa/Namibia, Special Publication of Geological Society of South African 13: 195-245.

Ernesto M (1990) Palaeomagnetism of the Mesozoic Serra Geral Formation, southern Brazil. Physics of the Earth and Planetary Interiors 64: 153-175.

Ernesto M., Raposo M.I.B., Marques L.S., Renne P.R., Diogo L.A., de Min A. (1999) Paleomagnetism, geochemistry and ${ }^{40} \mathrm{Ar} /{ }^{39} \mathrm{Ar}$ dating of the North-eastern Paraná Magmatic Province: tectonic implications. Journal of Geodynamics 28: 321-340.

Ernesto M., Bellieni G., Piccirillo E.M., Marques L.S., de Min A., Pacca I.G., Martins G., Macedo J.W.P. (2002) Paleomagnetic and geochemical constraints on the timing and duration of the CAMP activity in Northeastern Brazil. In: Hames W.E., Renne P.R., Ruppel C. (Eds.). The Central Atlantic Magmatic Province. American. Geophysical. Union Monography 136: 91-128.

Ernesto M. (2007) Drift of South America Platform since Early Cretaceous: Revewing the apparent polar wander path. Geociências 25: 83-90. 
Ernst R.E. (1990) Magma flow directions in two mafic Proterozoic dyke swarms of the Canadian Shield: as estimated using anisotropy of magnetic susceptibility data. In: Parker, Rickwood, Tucker (Eds.), Mafic Dykes and Emplacement Mechanisms. Balkema, Rotterdam, pp. 231-235.

Ernst R.E., Buchan K.L., Palmer H.C. (1995) Giant dyke swarms: Characteristics, distribution and geotectonic implications. In: Baer, G, Heimann, A (Eds.), Physics and Chemistry of Dykes. A.A. Balkema, Rotterdam, pp. 3-21.

Ernst R.E., Buchan K.L. (1997) Giant radiating dyke swarms; their use in identifying pre-Mesozoic large igneous provinces and mantle plume. In: Mahoney J.J. \& Coffin M.F. (Eds.). Large Igneous Provinces; Continental, Oceanic, and Planetary Flood Volcanism. American. Geophysical. Union Monography 100: 297-333.

Ernst R.E., \& Buchan K.L. (2001) Mantle Plumes: Their Identification through Time. Geological Society of America Special Paper 352: 592 pp.

Estrella G.O. (1972). O estágio rift nas bacias marginais do Leste Brasileiro. In: $26^{\circ}$ Congresso Brasileiro de Geologia, Belém, Resumos (3): 29-34.

Ewart A., Marsh J.S., Milner S.C., Duncan A.R., Kamber B.S., Armstrong R.A. (2004) Petrology and geochemistry of Early Cretaceous bimodal continental flood volcanism of NW Etendeka, Namibia. Part I: Introduction, mafic lavas and re evaluation of mantle source components. Journal of Petrology 45(1): 59105.

Fahrig W.F. (1987) The tectonic setting of continental mafic dyke swarms: failed arm and early passive margin. In: Halls H.C. \& Fahrig W.F. (Eds). Mafic Dyke Swarms. Geological Association of Canada, Special Paper 34: 331-348.

Farley K.A. \& Neroda E. (1998) Noble gases in the Earth's mantle. Annual Review of Earth and planetary Sciences 26: 189-218.

Faure G. (1986) Principles of isotope geology. 2nd edition, John Wiley \& Sons, Inc. 589p.

Faure S., Tremblay A., Angelier J. (1996) State of intraplate stress and tectonism of northeastern North America since Cretaceous times, with particular emphasis on the New England - Quebec igneous province. Tectonophysics 255: 111-134.

Féraud G., Giannérini G., Campredon R. (1987) Dyke Swarms as paleostress indicators in areas adjacent to continental collision zones: Examples from the european ans northwest arabian plates. Geological Association of Canada Special Paper 34: 273-278.

Féraud F. \& Campredon R. (1983) Geochronological and Structural study of tertiary and quaternary dikes in southern France and Sardinia: An example of the utilization of dike swarms as paleostress indicators. Tectonophysics 98: 297-325.

Ferrari A.L. (2001) Evolução tectônica do Gráben da Guanabara. Tese de Doutorado, Instituto de Geociências, Universidade de São Paulo, 412p.

Ferreira F.J.F. (1982 ${ }^{\mathrm{a}}$ ) Alinhamentos estruturais-magneticos da região centro-oriental da Bacia do Paraná e seu significado tectônico. In: Bacia do Paraná - Reavaliação da potencialidade e prospectividade em hidrocarbonetos. Consórcio CESP-IPT (Paulipetro) p. 143-166.

Ferreira F.J.F. (1982 ${ }^{\text {b }}$ Integração de dados aeromagnéticos e geológicos: configuração e evolução do Arco de Ponta Grossa. 1982a. Dissertação de Mestrado, Instituto de Geociências. Universidade de São Paulo. 169 p.

Figueró J. E. P., Viero A. P. \& Roisenberg A. (1996) Aspectos Geoquímicos e Petrogenéticos do Vulcanismo Toleítico Mesozóico da Formação Passo das Carretas, Santana da Boa Vista, RS. In: $39^{\circ}$ Congresso Brasileiro de Geologia, Salvador, Resumos, 2: 65-68. 
Florisbal L.M., Janasi V.A., Heaman L.M., Nardi L.V.S., Bitencourt M.F. (2011) O enxame de diques de Florianópolis na região de Garopaba, SC: Idade U-Pb TIMS em Badeleíta e relação com o vulcanismo Serra Geral. In: $5^{\circ}$ Simpósio de Vulcanismo e Ambientes Associados, Resumos.

Fodor R.V., McKee E.H., Asmus H.E. (1984) K-Ar ages and the opening of the South Atlantic Ocean: Basaltic rocks from the Brazilian margin. Marine. Geology 54: 1-8.

Fodor R.V. \& Vetter S.K. (1984) Rift-zone magmatism: Petrology of basaltic rocks transitional from CFB to MORB, southeastern Brazil margin. Contribution to Mineralogy and Petrology 88: 307-321.

Fontana R.L. (1987) Desenvolvimento termomecânico da Bacia de Pelotas e parte sul da plataforma de Florianópolis. Dissertação de Mestrado, Universidade. Federal de Ouro Preto. 128 p.

Fonseca M.J.G., Silva Z.C., Campos D.A. (1979) Carta geológica do Brasil ao milionésimo. Folhas Rio de Janeiro (SF-23)/Vitória (SF-24)/Iguape (SG-23). Texto Explicativo. DNPM.

Foulger G.R. \& Natland J.H. (2003) Is "hotspot" volcanism a consequence of plate tectonics? Science 300: $921-922$.

Foulger G.R., Natland J.H., Presnall D.C., Anderson D.L. (Eds.), Plates, Plumes, and Paradigms. Geological Society of America Special Volume 388, pp.

Foulger G.R. (2010) Plates vs Plumes: A Geological Controversy, Wiley-Blackwell, 328p.

Fragoso Cesar A.R.S. (2008) Novas considerações sobre o Ciclo Brasiliano. In: $44^{\circ}$ Congresso Brasileiro de Geologia, Curitiba, Resumos, pág. 28.

Fragoso César A.R.S., Figueiredo M.C.H., Soliani Jr. E., Faccini U.F. (1986) O Batólito

Pelotas (Proterozóico Superior/Eo-Paleozóico) no Escudo do Rio Grande do Sul. In: 34 Congresso Brasileiro de Geologia, Goiânia, Resumos, 3: 1322-1343.

Fragoso Cesar A.R.S. (1980) O Cráton Rio de La Plata e o Cinturão Dom Feliciano no Escudo UruguaioSul-Riograndense. In: $31^{\circ}$ Congresso Brasileiro de Geologia, Camboriú, Resumos, 5: 2879-2892.

França R.L. (2007)Bacia Espírito Santo. Boletim de Geociências da Petrobras 15(2): 501-509.

Franco-Magalhães A.O.B. (2009) Exumação tectônica e evolução associada do relevo no Arco de Ponta Grossa, sul-sudeste do Brasil. Tese de Doutoramento, Universidade Estadual Paulista. 121 p.

Franco-Magalhães A.O.B., Hackspacher P.C., Saad A.R. (2010) Exumação tectônica e reativação de paleolineamentos no Arco de Ponta Grossa: termocronologia por traços de físsão em apatitas. Revista Brasileira de Geociências 40(2): 184-495.

Freitas V.A. (2009) A geração de magmas ácidos na Província Magmática do Paraná, região de PirajuOurinhos (SP): uma contribuição da geoquímica isotópica e de elementos traço em rochas e minerais. Dissertação de Mestrado. Instituto de Geociências. Universidade de São Paulo. 193p.

Fúlfaro V J \& Suguio K. (1969) Campos de diques de diabásio da bacia do Paraná. Boletim da Sociedade Brasileira de Geologia 16 (2): 23-37.

FúlfaroV.J., Saad A.R.; Santos, M.V.; Vianna R.B. (1982) Compartimentação e evolução tectônica da Bacia do Paraná. Revista Brasileira de Geociências 12(4):590-611.

Gallagher K., Hawkesworth C.J., Mantovani M. (1994) The denudation history of the onshore continental margin os SE Brazil inferred form apatite fission track data. Journal of Geophysical Research 99(B9): 18117-18145.

Gallagher K. \& Hawkesworth C.J. (1994) Mantle plumes, continental magmatism and asymmetry in the South Atlantic. Earth and Planetary Science Letters 123: 105-117. 
Gallagher K. \& Hawkesworth C.J. (1992). Dehydration melting and the generation of continental flood basalts. Nature 358: 57-59.

Garda G. M. (1995) Os diques básicos e ultrabásicos da região costeira entre as cidades de São Sebastião e Ubatuba, Estado de São Paulo. Tese de Doutorado. Instituto de Geociências, Universidade de São Paulo. 156p.

Geoffroy L., Bergerat F., Angelier J. (1993) Modification d'un champ de contrainte régional par un champ de contraintes mamatique local. Exemple de l'Ille de Skye (Ecosse) au Paléoéne. Bulletin de la Societé Géologique de France 164 (4): 541-552.

Glazner A.F., Bartley J.M., Walker J. D. (1988) Geology of the Waterman Hills detachment fault, central Mojave Desert, California. In: Weide L.D. \& Faber M.L. (Eds.). This Extended Land- Geological Surveys in the Southern Basin and Range. University of Nevada. 225-237 pp.

Glazner A., Bartley J., Carl B., (1999) Oblique opening and noncoaxial emplacement of the Jurassic independence dike swarm, California. Journal of Structural Geology 21: 1275-1283.

Gonzaga de Campos L.F. (1889) Secção geológica. In: São Paulo, Comissão Geographica e Geológica do Estado de São Paulo. Relatório Interno. 13p.

Gordon Jr. M. (1947) Classificação das formações gondwânicas do Paraná, Santa Catarina e Rio Grande do Sul Notas Preliminares e Estudos - DNPM/DGM 38: 1-20.

Gomes P.O., Gomes B.S., Palma J.J.C., Jinno K., Souza J.M. (2000) Ocean-Continent Transition and Tectonic Framework of the Oceanic Crust at the Continental Margin of NE Brazil: Results of LEPLAC Project.

Gradstein F.M., Agterberg F.F., Ogg J.G. (1995) "A Triassic, Jurassic and Cretaceous Time Scale". In: Berggren W.A., Kent D.V., Aubry M.P., Hardenbol J. (Eds.) Geochronology, Time Scales and Global Stratigraphic Correlation, SEPM Special Publication No. 54, pp. 95-126. Tulsa, OK: Society for Sedimentary Geology.

Gradstein F.M., Ogg J.G., Smith A.G., Agterberg F.P., Bleeker W., Cooper R.A., Davydov V., Gibbard P., Hinnov L., House M.R., Lourens L., Luterbacher H.P., McArthur J., Melchin M.J., Robb L.J., Shergold J., Villeneuve M., Wardlaw B.R., Ali J., Brinkhuis H., Hilgen F.J., Hooker J., Howarth R.J., Knoll A.H., Laskar J., Monechi S., J.Powell, Plumb K.A., Raffi I., Röhl U., Sanfilippo A., Schmitz B., Shackleton N.J., Shields G.A., Strauss H., Van Dam J., Veizer J., Kolfschoten T., Wilson D. (2010) A Geologic Time Scale 2010. Cambridge University Press.500 p.

Greenough J.D. \& Hodych J.P. (1990) Evidence for lateral magma injection in the Early Mesozoic dykes of Eastern North America. In: Parker A.J., Rickwood P.C., Tucker D.H. (Eds). Mafic Dykes and Emplacement Mechanisms. Proceedings of the Second International Dyke Conference. pp. 35-46.

Griffiths R.W. \& Campbell I.H. (1991) Interaction of mantle plume heads with the Earth's surface and onset of small scale convection. Journal of Geophysical Research 96 (B11): 18295-18310.

Guedes E., Heilbron M., Vasconcelos P.M., de Morisson Valeriano C., Horta de Almeida J. C., Teixeira W., Filho A. T. (2005) K-Ar and ${ }^{40} \mathrm{AR} /{ }^{39} \mathrm{Ar}$ ages of dikes emplaced in the onshore basement of the Santos Basin, Resende area, SE Brazil: implications for the south Atlantic opening and Tertiary reactivation. Journal of South American Earth Sciences 18: 371-382.

Hackspacher P.C., Ribeiro L.F.B.; Ribeiro M.C.S., Fetter A.H., Hadler Neto J.C., Tello Saenz C.A., Dantas E.L. (2004) Consolidation and Break-up of the South American Platform in Southeastern Brazil: Tectonothermal and Denudation Histories. Gondwana Research 7 (1): 91 - 101.

Halls H.C. \& Fahrig W.F. (1987) Mafic Dyke Swarms. Special Paper 34. Geological Society of Canada. 503 pp. 
Halls, H. C. (1982) The importance and potential of mafic dyke swarms in studies of geodynamic processes. Geoscience of Canada 9: 145-154.

Halls H.C. \& Bates M.P. (1990) The evolution of the 2.45 Ga Matachewan dyke swarm, Canada. In: Parker J., Rickwood P.C. \& Tucker D.H. (Eds.) Mafic dykes and emplacement machanisms. Rotterdam, Balkema, p. 237-249.

Hancock P.L. (1972) The analysis of en echelon veins. Geological Magazine 109: 269-276.

Hargraves R.B., Johnson D., Chan C.Y. (1991) Distribution anisotropy: the cause of AMS in igneous rocks? Geophysical Research Letters 18: 2193-2196.

Harland W.B., Armstrong R.L., Cox A.V., Craig L.E., Smith A.G., Smith D.G. (1989) A Geologic Time Scale 1989 edition. Cambridge University Press: Cambridge. 263pp.

Harry D.L. \& Sawyer D.S. (1992) Basaltic volcanism, mantle plumes, and the mechanics of rifting: the Paraná flood basalt province of South America. Geology 20: 207-210.

Hasui Y., Penalva F., Hennies W.T. (1969) Geologia do Grupo São Roque. In: $23^{\circ}$ Congresso Brasileiro de Geologia, Salvador, Resumos, p.101-134.

Hasuy Y., Dantas A.S., Carneiro C.D.R., Bistrichi C.A. (1981) O Embasamento Pré- Cambriano e Eopaleozóico em São Paulo. In: Instituto de Pesquisas Tecnológicas, Mapa Geológico do Estado de São Paulo, PRÓ-MINÉRIO/PROMOCET. p. 12-45.

Hasuy Y. Oliveira M.A.F. (1984) Província Mantiqueira - Setor Central. In: Almeida F.F.M. \& Hasuy Y. (Eds.). O Pré-Cambriano do Brasil, Edgard Blücher, São Paulo, 378p.

Hawkesworth C.J., Gallager K., Kelley S., Mantovani M.S.M., Peate D., Regelous M., Rogers N. (1992) Paraná magmatism and the opening of the South Atlantic. In: Storey B., Alabaster A., Pankhurst R. (Eds.). Magmatism and the Causes of Continental Break-up. Geological Society Special Publication 68: 221240.

Hawkesworth C.J. \& Gallagher K. (1993). Mantle hotspots, plumes and regional tectonics as causes of intraplate magmatism. Terra Nova 5: 552-559.

Hennies W.T., Hasui Y., Penalva F. (1967) O falhamento transcorrente de Taxaquara. In: $21^{\circ}$ Congresso Brasileiro de Geologia, Curitiba, Resumos 159-168.

Hess, H.H. (1960). "Nature of great oceanic ridges". Preprints of the 1st International Oceanographic Congress (New York, August 31-September 12, 1959). Washington: American Association for the Advancement of Science. (A). pp. 33-34.

Hill R. (1991) Starting plumes and continental break-up. Earth and Planetary Science Letters 104: 398416.

Hinz K. (1981) A hypothesis on terrestrial catastrophes: wedges of very thick oceanward dipping layers beneath passive continental margins $\mathrm{D}$ their origin and paleoenvironmental significance. Geologische Jahrebuch, Reihe E, Geophysik, 22, 3-28.

Hinz K. \& Weber J (1976) Zum geologischen Aufbau des Norwegischen Kontinentalrandes und der Barents-See nachre ${ }^{-}$exionsseismischen Messungen. Erdol und Kohle, Erdgas Petrochemie, Compendium 57/76, 3-29.

Hinz K., Mutter J. C., Zehnder C.M. \& the NGT Study Group (1987) Symmetric conjugation of continent-ocean boundary structures along the Norwegian and east Greenland margins. Marine Petroleum Geology 4: 166-187. 
Hiruma S.T., Riccomini C., Modenesi-Gauttieri M.C., Hackspacher P.C., Hadler J.C., Franco-Magalhães A.O.B. (2010) Denudation history of the Bocaina Plateau, Serra do Mar, southeastern Brazil: Relationships to Gondwana breakup and passive margin development. Gondwana Research 18: 674-687.

Hoek J.D. (1991) A classification of dyke-fracture geometry with examples from the Precambrian dyke swarms in the Vestfold Hills, Antarctica. International Journal of Earth sciences 80: 233-248.

Hoffman P.F. (1989) Precambrian geology and tectonic history of North America. In: Bally A.W. \& Palmer A.R. (Eds.) The Geology of North America-An overview. Geological Society of America.

Hofmann C., Courtillot V., Féraud G., Rochette P., Yirgu G., Ketefo E., Pik R. (1997) Timing of the Ethiopian flood basalt event and implications for plume birth and global change. Nature 389: 838-841.

Hofmann C., Féraud G., Courtillot V. (2000) ${ }^{40} \mathrm{Ar} /{ }^{39}$ Ar dating of mineral separates and whole rocks from the Western Ghats lava pile: further constraints on duration and age of the Deccan Traps, Earth Planetary Science Letters 180: 13-27.

Holmes A. (1929) Radioactivity and earth movements: Transactions of the Geological Society of Glasgow 18: (Part 3), pp. 559- 606.

Holmes A. (1944). Principles of Physical Geology (1 ed.). Edinburgh: Thomas Nelson \& Sons. 580p.

Holmes A. (1965) Principles of Physical Geology . Thomas Nelson \& Sons Ltd., London and Edinburgh. Segunda Edição. 1287p.

Hooper P.R. (1990) The timing of crustal extension and the eruption of continental flood basalts. Nature 345: $246-249$

Iacumin M., Piccirlilo E.M., Girardi V.A., Teixeira W., Bellieni G., Echeveste R., Fernandez R., Pinese J.P.P., Ribot A. (2001) Early Proterozoic Calc-Alkaline and Middle Proterozoic Tholeiitic Dyke Swarms from Central-Eastern Argentina: Petrology, Geochemistry, Sr-Nd Isotopes and Tectonic Implications. Journal of Petrology 42(11): 2109-2143.

IPT - Instituto de pesquisas tecnológicas do Estado de São Paulo (1981) Mapa geológico do Estado de São Paulo; escala 1:500.000. v1 (texto) e v2 (mapa). Governo do estado de São Paulo. Secretaria da Indústria, Comércio, Ciência e Tecnologia.

Ita J. \& Stixrude L. (1992) Petrology, elasticity, and composition of the mantle transition zone. Journal of Geophysical Research 97(B5): 6849- 6866.

Jackson M.P.A., Cramez C., Fonck J. M. (2000) Role of subaerial volcanic rocks and mantle plumes in creation of South Atlantic margins: implications for salt tectonics and source rocks. Marine and Petroleum Geology 17: 477-498.

Jacobs J.A. (1974) Physics and Geology. New York : McGraw-Hill. 622 p.

Janasi V.A., Freitas V.A., Heaman L.H. (2010) The onset of flood basalt volcanism, Northern Paraná Basin, Brazil: A precise U-Pb baddeleyite/zircon age for a Chapecó-type dacite. Earth and Planetary Science Letters 302: 147-153.

Jelinek A.R., Bastos Neto A.C., Lelarge M.L.V., Soliani Jr. (1999) Apatite fission track dating of fluorite ore veins from Santa Catarina state, Brazil: a complex hydrothermal evolution. Journal of South American Earth Science 12: 367-377.

Jerram D., Moutney N., Hololzforster F., Stollhofen H. (1999) Internal stratigraphic relationships in the Etendeka Group in the Huab Basin, NW Namibia: understanding the onset of the flood volcanism. Journal of Geodynamics 28: 393-418.

Jolly R.J.H. \& Sanderson D.J. (1995) Variations in the form anddistribution of dykes in the Mull swarm, Scotland. Journal of Structural Geology 17: 1543-1557. 
Jourdan F., Feraud G., Bertrand H., Watkeys M.K., Kampunzu A.B., Le Gall B. (2006) Basement control on dyke distribution in Large Igneous Provinces: case study of the Karoo triple junction. Earth Planetary Science Letters 241: 307-322.

Karniol T. (2000) Análise geométrica e cinemática de um segmento do Complexo Costeiro na região de São Sebastião. Trabalho de Conclusão de Curso. Instituto de Geociências. Universidade de São Paulo.

Kattenhorn S.A. \& Watkeys M.K. (1995) Blunt-ended dyke segments. Journal of Structural Geology 17: $1535-1542$

Kearey P., Keith A.K., Frederick J.V. (2009) Global Tectonics. John Wiley \& Sons. 496pp.

Keller G. R., Lidiak, E. G., Hinze, W. J., Braile, L. W. 1983. The role of rifting in the tectonic development of the midcontinent, U.S.A. Tectonophysics 94: 391-412.

King S.D. \& Anderson D.L. (1995) An alternative mechanism to flood basalt formation, Earth Planetary Science Letters 136: 269-279.

König M., \& Jokat W. (2006). The Mesozoic breakup of the Weddell Sea. Journal of Geophysical Research 111(B12):102-130.

Krogh TE, Davis DW, Corfu F (1984) Precise U-Pb zircon and baddeleyite ages for the Sudbury area. In: Pye E.G., Naldrett A.J., Giblin P.E. (Eds.) The Geology and Ore Deposits of the Sudbury Structure. Ontario Geological Survey Special Volume 1: 431-446.

Lajtai E.Z. (1969) Mechanics of second order faults and tension gashes. Geological Society of America Bulletin 80:2253-2272.

Larsen H.C. \& Jakobsdíttir S. (1988). Distribution, crustal properties and significance of seawardsdipping sub-basement reflectors of E Greenland. In: Morton A. C., Parson L.M. Early Tertiary Volcanism and the Opening of the NE Atlantic. Geological Society of London Special Publication 39: 95-114.

Lawver L.A., Gahagan L.M., Dalziel I.W.D. (1999) Antarctica, Keystone of Gondwana, http://www.ig.utexas.edu/research/projects/plates/movies/akog.ppt

Le Gall B., Tshoso G., Dyment J., Kampunzu A.B., Jourdan F., Féraud G., Bertrand H., Aubourg C., Vétel V. (2005) Structure of the Okavango giant mafic dyke swarm (NE Botswana) and its significance within the Karoo large igneous province of southern Africa. Journal of structural Geology 27: 2234-2255.

Leinz V. (1949) Contribuição à geologia dos derrames basalticos do sul do Brasil. Tese de Doutorado. Faculdade de Filosofia, Ciências e Letras. Universidade de São Paulo, São Paulo. 61 p.

Liss D., Hutton D.H.W., Owens W.H. (2002) Ropy flow structures: a neglected indicator of magma-flow direction in sills and dikes. Geology 30: 715-718.

Lobo J.T.(2000) Petrogênese dos basaltos do Cretáceo Inferior das bacias de Campos e Pelotas, SE do Brasil. Dissertação de Mestrado. Faculdade de Geologia. Universidade do Estado do Rio de Janeiro. 97p.

Lohmann H.H., Hoffmann-Rolhe J., Hinz K. (1995) Argentine. In: Kulke, H. Regional petroleum geology of the world. Part II: Africa, America, Australia and Antarctica. 650p.

Maaløe S. (1998) Shape of ascending feeder dikes, and ascent modes of magmas. Journal of Volcanology and Geothermal Research 81: 207-214.

Macedo J.M. (1990) Evolução tectônica da Bacia de Santos e áreas continentais adjacentes. In: Raja Gabaglia G. P. \& Milani E. J. (Eds.). Origem e evolução de bacias sedimentares. Rio de Janeiro, PETROBRAS, p. 361-376. 
Machado Jr. D.L. (2000) Condicionamento Estrutural e Contexto Tectônico do "Alinhamento de Guapiara”. Tese de Doutorado. Instituto de Geociências, Universidade de São Paulo. 143p.

Mantovani M.S.M., Marques L.S., Souza M.A.D., Civetta L., Atalla M., Innocenti F. (1985) Trace element and strontium isotope constraints on the origin and evolution of Paraná Continental Flood Baalts of Santa Catarina State (southern Brazil). Journal of Petrology 26: 187-209.

Marini O.J., Fuck R.A., Trein E. (1967) Intrusivas básicas Jurássico-Cretáceas do Paraná. Boletim Paranaense de Geociências 26: 85-124.

Marrett R. \& Peacock D.C.P. (1999) Strain and stress. Journal of Structural Geology 21: 1061-1067.

Marsh J.S., Ewart A., Milner S.C., Duncan A.R., Miller R. (2001) The Etendeka Igneous Province: magma types and their stratigraphic distribution with implications for the evolution of the Paraná Etendeka flood basalt province. Bulletin of Volcanology 62: 464-486.

Marques L.S., Dupre B., Piccirillo E. M. (1999) Mantle source compositions of the Paraná Magmatic Province (southern Brazil): evidence from trace elements and $\mathrm{Sr}-\mathrm{Nd}-\mathrm{Pb}$ isotope geochemistry. Journal of Geodynamics 28: 439-458.

Marques L.S. (2001) Geoquímica dos diques toleíticos da costa sul-sudeste do Brasil: contribuição ao conhecimento da Província Magmática do Paraná. 2001. 86 f. Tese (livredocência) - Instituto Astronômico, Geofísico e de Ciências Atmosféricas, Universidade de São Paulo.

Marques L.S. (2008) Tectônica de placas, plumas, heterogeneidades do manto e a origem da Província Magmática do Paraná. In: IV Simpósio de Vulcanismo e Ambientes Associados, Foz do Iguaçu. v. CDROM.

Marques L.S. \& Ernesto M. (2004) O Magmatismo Toleítico da Bacia do Paraná. In: Mantesso Neto V., Bartorelli A., Carneiro C.R., Brito Neves B.B. (Eds.). Geologia do continente Sul-Americano: evolução da obra de Fernando Flávio Marques de Almeida. São Paulo: Beca Produções Culturais, p. 245-263.

Marton G.L, Tari G.C., Lehmann C.T. (2000) Evolution of the Angolan passive margin, West Africa, with emphasis on post-salt structural styles. In: Mohriak W.U. \& Talwani M. (Eds.) Atlantic Rifts and Continental Margins American Geophysical Union Monography 115: 129-149.

Marzoli A., Melluso L., Morra V., Renne P.R., Sgrosso I., D’Antonio M., Duarte Morais L., Morais E.A.A., Ricci G. (1999) Geochronology and petrology of Cretaceous basaltic magmatism in the Kwanza basin western Angola, and relationships with the Paranà-Etendeka continental flood basalt province. Journal of Geodynamics 28: 341-356

Masquelin H., Aifa T., Muzio R., Hallot E., Veroslavsky G., , Bonnevalle L. (2009) The Cuaró Mesozoic doleritic dyke swarm, southern Paraná basin, Uruguay: examples of superimposed magnetic fabrics? Comptes Rendus Geoscience 341 (12): 1003-1015.

May P.R. (1971) Pattern of Triassic-Jurassic diabase dikes around the North Atlantic in the context of the predrift positions of the continents. Geological. Society of American. Bulletin 82:12851292.

Mège D., Korme T. (2004) Dyke swarm emplacement in the Ethiopian Large Igneous Province: not only a matter of stress. Journal of Volcanology and Geothermal Research 132: 283-310.

Menzies M.A., Klemperer S.A., Ebinger C.J., Baker J. (2002) Volcanic Rifted Margins. Geological Society of America Special Paper 362. Geological Society of America. 230p.

Meyers J.B., Rosendahl B.R., Austin-Jr. J.A. (1996). Deep-penetrating MCS imaging of the South Gabon Basin: Implications for rift tectonics and post-breakup salt remobilization. Basin Research 8: 65-84. 
McHone J.G. (1988) Tectonic and paleostress patterns of Mesozoic intrusions in eastern North America. In: Manspeizer W. (Ed.). Triassic-Jurassic Rifting: continental breakup and the origins of the Atlantic Ocean and passive margins. Elsevier, New York, pp. 607-620.

McHone J.G. (2000) Non-plume magmatism and tectonics during the opening of the central Atlantic Ocean. Tectonophysics 316: 287-296.

McHone J.G., Anderson D.L., Beutel E.K., Fialko Y.A. (2005) Giant dykes, flood basalts, and plate tectonics: A contention of mantle models. In: Foulger G.R., Natland, J.H., Presnall D.C., Anderson D.L. (Eds.) Plates, plumes and paradigms, Geological Society of America Special Paper, 388, p. 401-420.

McKenzie D. (1984) The generation and compaction of partially molten rock. Journal of Petrology $25: 713-765$.

McKenzie D. \& Bickle M.J. (1988) The volume and composition of melt generated by extension of the lithosphere. Journal of Petrology 29 (3): 625-679.

Melfi A.J., Piccirillo E.M., Nardy J.R. (1988). Geological and magmatic aspects of the Paraná Basin. In: Piccirillo E.M., Melfi A.J. (Eds.). The Mesozoic Flood Volcanism of the Paraná Basin. Instituto Astronômico e Geofísico. Universidade de São Paulo. São Paulo, pp. 1-13.

Milani E.J. (1997) Evolução tectono-estratigráfica da Bacia do Paraná e seu relacionamento com a geodinâmica fanerozóica do Gondwana Sul-Ocidental. Tese de Doutorado. Instituto de Geociências, Universidade Federal do Rio Grande do Sul. Porto Alegre. 255 p.

Milani E. J. \& Thomaz Filho A. (2000) Sedimentary basins of South America. In: Cordani U.G., Milani E.J. Thomaz Filho A., Campos D.A. (Eds.) Tectonic evolution of South America, 31st International Geological Congress, Rio de Janeiro, 389-449.

Milani E.J., Rangel H.D., Bueno G.V., Stica J. M., Winter W.R., Caixeta J.M., Pessoa Neto O.C. (2007) Bacias Sedimentares Brasileiras - Cartas Estratigráficas: Introdução. Boletim de Geociências da Petrobras15 (2): 183-205.

Milner S.C., Le Roex A.P., O’Connor J.M. (1995) Age of Mesozoic igneous rocks in northwest Namibia and the relationship to continental breakup. Journal of Geological Society of London 151: 97-104.

Mizusaki A.M.P., Thomaz Filho A., Cesero P. (1998) Ages of the magmatism and the opening of the South Atlantic Ocean. Pesquisas 25 (2): 47-57.

Mizusaki A.M.P., Thomaz Filho A., Milani E.J., Cesero P. (2002) Mesozoic and Cenozoic igneous activity and its tectonic control in northeastern Brazil. Journal of South American Earth Sciences 15: 183-198.

Mohriak W.U., Szatmari P., Anjos S.M.C. (2008) Sal: Geologia e Tectônica. Beca. 448p.

Mohriak W.U. (2003) Bacias Sedimentares da Margem Continental Brasileira. In: Bizzi L.A., Schobbenhaus C., Vidotti R.M., \& Gonçalves J.H. (Eds.). Geologia, Tectônica e Recursos Minerais do Brasil. Companhia de Pesquisas de Recursos Minerais.p. 87-165.

Mohriak W.U. Rosendahl B.R., Turner J.P., Valente S.C. (2000) Crustal architecture of South Atlantic volcanic margins. In: Menzies M.A., Klemperer S.L., Ebinger C.J., Baker J. (Eds.) Volcanic Rifted Margin. Special Paper Geological Society of America 362: 159-202.

Monteiro H.L.J. \& Valente S.C. (2003) Estudo petrológico comparativo das suítes de baixo $\mathrm{TiO}_{2}$ do Enxame de Diques da Serra do Mar: Jornada de Iniciação Científica, Universidade Federal Rural do Rio de Janeiro, Seropédica, p. 54-55.

Montelli R., Nolet G., Dahlen F., Masters G. (2006) A catalogue of deep mantle plumes: new results from finite frequency tomography. Geochemistry, Geophysics and Geosystems 7. 
Moreira J.L.P., Madeira C.V., Gil J.A., Machado M.A.P. (2007) Bacia de Santos. Boletim de Geociências da Petrobras 15(2): 531-549.

Morgan W.J. (1971) Convective plumes in the lower mantle. Nature 230: 42-43.

Moulin M., Aslanian D., Unternher P. (2010) A new starting point for the South and Equatorial Atlantic Ocean. Earth Science Reviews 97(1-4): 59-95.

Muller R.D., Royer J-Y., Lawver L.A. (1993) Revised plate motions relative to hotspots from combined Atlantic and Indian hotspot tracks. Geology 21: 275-278.

Mutter J., Talwani M., Stoffa P.L. (1982). Origin of seaward dipping reflectors in oceanic crust off the Norwegian margin by "subaerial seafloor spreading". Geology 10: 353-357.

Nakamura K. (1977). Volcanoes as possible indicators of tectonic stress orientation; principle and proposal. Journal of Volcanology and Geothermal Research 2(1): 1-16.

Nardy A.J.R., Oliveira M.A.F., Betancourt R.H.S., Verdugo D.R.H., Machado F.B. (2002) Geologia e estratigrafia da Formação Serra Geral. Revista Brasileira de Geociências 21:15-32.

Nicholson R. \& Pollard D.D. (1985) Dilation and linkage of en echelon cracks. Journal of Structural Geology 7: 583-590.

Noble J. A. (1952) Evaluation of criteria for the forcible intrusion of magma. Journal of Geology 60: 3457.

Novais L.C.C., Teixeira L.B., Neves M.T., Rodarte J.B.M., Almeida J.C.H., Valeriano C.M. (2003) Novas ocorrências de diques de diabásio na faixa Colatina - ES: estruturas rúpteis associadas e implicações tectônicas para as bacias de Campos e do Espírito Santo. Boletim de Geociências da Petrobras 12(1): 191-194.

Nürnberg D. \& Müller R. D. (1991) The tectonic evolution of the South Atlantic from Late Jurassic to present. Tectonophysics 191: 27-53.

O’Connor J.M., Duncan R.A. (1990) Evolution of the Walvis Ridge-Rio Grande Rise Hot Spot System: implications for African and South American plate motions over plumes. Journal of Geophysical. Research 95(B11): 17475-17502.

Odé H. (1957) Mechanical analysis of the dike pattern of the Spanish Peaks area, Colorado. Geological Society of America Bulletin 68: 567-576.

Oliveira E.P., Souza Z.S., Corrêa-Gomes L.C. (2000) U-Pb dating of deformed mafic dyke and host gneiss: implications for understanding reworking processes on the western margin of the Archaean Uauá block, NE São Francisco Craton, Brazil. Revista Brasileira de Geociências30 (1): 149-152.

Olsen K.H. \& Morgan P. (1995) Introduction: Progress in understanding continental rifts. In: Olsen K.H. (Ed.). Continental rifts: evolution, structure, tectonics. Developments in Geotectonics 25: 3-26.

Onstott T.C., Buser G., Muneer H. (1993) Analyses of P1 to P31 samples, well API-1-PR (Brazil) report 93-1 to PETROBRÁS. Princeton University. 64p.

Oreskes N. (1999) The Rejection of Continental Drift: Theory and Method in American Earth Science. Oxford University Press. 420p.

Pálmason G. (1980). A continuum model of crustal generation in Iceland: Kinematic aspects. Journal of Geophysics 47: 7-18.

Peate D. W. (1990) Stratigraphy and petrogenesis of the Paraná continental flood basalts, southern Brazil. $\mathrm{Ph}$. D. thesis, The Open University. 
Peate D.W., Hawkesworth C.J., Mantovani M.S.M. (1992) Chemical stratigraphy of the Paraná lavas (South America): classification of magma types and their spatial distribution. Bulletin of Volcanology 55: 119-139.

Peate D.W. (1997) The Parana-Etendeka Province. In: Mahoney J.J., Coffin M.F. (Eds.), Large Igneous Provinces: Continental, Oceanic, and Planetary Flood Volcanism. American Geophysical Union Monography 100: 217-246.

Piccirilo E.M., Melfi A.J., Comin-Chiaramonti P.; Bellieni G., Ernesto M., Marques L.S., Nardy A.J.R., Pacca I.G., Rosenberg A., Stolfa D. (1988) Continental Flood Volcanism from the Paraná Basin (Brazil). In: McDougall J. D. (Ed.) Continental Flood Basalts. 195-238p.

Piccirilo E.M., Melfi A.J. (1988) The Mesozoic Flood Volcamism of the Paraná Basin: Petrogenetic and Geophysiscal Aspects. Instituto Astronômico e Geofísico Universidade de São Paulo, São Paulo. 600 p.

Piccirillo E.M., Bellieni G., Cavazzini G., Comin-Chiaramonti P, Petrini R., Melfi A.J., Pinese J.P.R, Zantadeschi R, De Min A. (1990). Lower Cretaceous tholeiitic dyke swarms from the Ponta Grossa Arch (southeast Brazil): Petrology, Sr-Nd isotopes and genetic relationships with the Paraná flood volcanics. Chemical Geology 89:19-48.

Pindell J. \& Dewey J. (1982) Permo-Triassic reconstruction of western Pangea and the evolution of the Gulf of Mexico/Caribbean region. Tectonics 1: 179-211.

Pinese J.P.P. (1989) Caracierização pelrológica e geoquímica dos diques do Arco de Ponta Grossa. Dissertação de Mestrado. Instituto Astronômico e Geofísico. Universidade de São Paulo. 196 p.

Pinto V.M., Hartmann L.A., Santos J.O.S., Mcnaughton N.J., Wildner W. (2010) Zircon U Pb geochronology from the Paraná bimodal volcanic province support a brief eruptive cycle at $\sim 135 \mathrm{Ma}$. Chemical Geology 281: 93-102.

Philpotts A.R. \& Asher P.M. (1994) Magmatic flow-direction indicators in a giant diabase feeder dike, Connecticut. Geology 22: 363-366.

Platten I.M. \& Watterson J. (1987) Magma flow and crystallization in dyke fissures. In: Mafic dyke swarms. Halls H.C. \& Fahrig W.F. (Eds.) Special Paper of geological Association of Canada 34: 65-73.

Pollard D.D. (1973): Derivation and evaluation of a mechanical model for sheet intrusions. Tectonophysics. 19: 233-269.

Pollard D.D. \& Muller O.H. (1976): The effect of gradients in regional stress and magma pressure on the form of sheet intrusions in cross section. Journal of Geophysical Research 81 (B): 975-984.

Pollard D.D., Delaney P., Duffield W., Endo E. \& Okamura A. (1983) Surface deformation in volcanic rift zones. Tectonophysics 94: 541-584.

Pollard D.D. (1987) Elementary fracture mechanics applied to the structural interpretation of dykes. Geological Association of Canada Special Paper 34: 5-24.

Pollard D.D., Segall P., Delaney P.T. (1982) Formation and interpretation of dilatant echelon cracks. Bulletin of geological Society of America 93: 1291-1303.

Ponte F.C. \& Asmus H.E. (1978). Geological framework of the Brazilian continental margin. Geol. Rundsch. 67: 201-235.

Prazeres Filho H.J. (2005) Caracterização geológica e getrogenética do batólito granítico Três Córregos (PR-SP): geoquímica isotópica (Nd-Sr-Pb), idades (ID-TIMS/SHRIMP) e O em zircão. Tese de doutorado. Instituto de Geociências. Universidade de São Paulo.

Rabinowitz P. \& LaBrecque J. (1979). The Mesozoic south Atlantic Ocean and evolution of its continental margins. Journal of Geophysical Research 84(B11). 
Ramsay J.G. (1980) Shear zone geometry: a review. Journal of Structural Geology 2: 83-99.

Ramsay J.G. \& Huber M.I. (1987) The Techniques of Modern Structural Geology. Volume 2: Folds and Fractures. Academic Press, London.

Raposo M.I.B. \& Ernesto M. (1989) Rochas intrusivas do Arco de Ponta Grossa: resultados Paleomagnéticos preliminares. Revista Brasileira de Geociências 19 (3): 393-400.

Raposo M. I. B. (1995) Episódios Intrusivos do Arco de Ponta Grossa determinados através de um estudo paleomagnético. Revista Brasileira de Geociências 25 (1): 3-19.

Raposo M.I.B. \& Ernesto M. (1995ª) Anisotropy of magnetic susceptibility in the Ponta Grossa dyke swarm (Brazil) and its relationship with the magma flow directions. Physics of the Earth and Planetary Interiors 87: 183-195.

Raposo M.I.B. \& Ernesto M. (1995 ${ }^{\mathrm{b}}$ ) An early Cretaceous paleomagnetic pole from Ponta Grossa dikes (Brazil): implications for the South America Mesozoic APWP. Journal of Geophysical Research 100 (B10): 20095-20109.

Raposo M.I.B. (1997) Magnetic fabric and its significance in the Florianopolis dyke swarm, southern Brazil. Geophysical Journal International 131: 159-170.

Raposo M.I.B., Ernesto M., Renne P.R. (1998) Paleomagnetism and 40Ar/39Ar dating of the early Cretaceous Florianópolis dike swarm (Santa Catarina Island), Southern Brazil. Physics of the Earth and Planetary Interiors. 108:275-290.

Renne P.R., Ernesto M., Pacca I.G., Coe R.S. Glen J.M., Prévot M., Perrin M. (1992) The Age of Paranà Flood Volcanism, Rifting of Gondwanaland and the Jurassic Cretaceous Boundary. Science 258: 975979.

Renne P. R., Deckart K., Ernesto M., Féraud G., Piccirillo E. (1996) Age of the Ponta Grossa dike swarmBrazil and implications to Parana flood volcanism. Earth and Planetary Science Letters 144: 199211.

Riccomini C. (1989) O Rift Continental do Sudeste do Brasil. 1989. Tese de Doutorado. Instituto de Geociências, Universidade de São Paulo. São Paulo, 256p.

Riccomini C. (1995) Tectonismo gerador e deformador dos depósitos sedimentares pós-Gondwânicos da porção centro-oriental do Estado de São Paulo e áreas vizinhas. Tese de Livre-Docência, Universidade de São Paulo, 100 p.

Riccomini C. \& Assumpção M. (1999) Quaternary tectonics in Brazil. Episodes 22 (3): 221-225.

Riccomini C., Velazquez V.F., Gomes C.B. (2005) Tectonic controls of the Mesozoic and Cenozoic alkaline magmatism in central-southeastern Brazilian Platform. In: Gomes C.B. \& Comin-Chiaramonti P. (Eds.). Mesozoic to Cenozoic alkaline magmatism in the Brazilian Platform. São Paulo: EDUSPFAPESP, p31-55.

Riccomini C., Santana L.G., Ferrari A.L. (2004) Evolução geológica do Rift Continental do Sudeste do Brasil. In: Mantesso Neto V., Bartorelli A., Carneiro C.D.R., Brito Neves B.B. (Eds.) Geologia do Continente Sul-Americano: Evolução da Obra de Fernando Flávio Marques de Almeida.Beca. p. 383-405.

Riccomini C., Brentan S., Tomba C.L.B., Ferrari A.L., Taioli F., Silva T.B. \& Manoel D.F.C. 2006. Regime tectônico de colocação dos enxames de diques eocretáceos do sudeste do Brasil. In: 43 Congresso Brasileiro de Geologia, Aracaju, Resumos, pág. 110.

Richards M.A., Duncan R.A., Courtillot V.E. (1989) Flood basalts and hot spot tracks: plume heads and tails. Science 246: 103-107. 
Rickard M. J. \& Rixon L. K. (1983) Stress configurations in conjugate quartz-vein arrays. Journal of Structural Geology 5: 573-578.

Rickwood P.C. (1990) The anatomy of a dyke and the determination of propagation and magma flow directions. In: Parker J., Rickwood P.C. \& Tucker D.H. (Eds.) Mafic dykes and emplacement machanisms. Rotterdam, Balkema, p.81-100.

Ringwood A.E. (1975) Composition and petrology of the Earth's Mantle. McGraw-Hill, New York, $618 \mathrm{pp}$.

Ritsema J. \& Allen R.M. (2003) The elusive mantle plume. Earth and Planetary Science Letters 207: 112.

Rocha-Campos A.C., Cordani U.G., Kawashita K., Sonoki H.M., Sonoki I.K. (1988) Age of the Paraná flood volcanism. In: Piccirillo E.M., Melfi A. J. (Eds) The Mesozoic Flood Volcanism of the Paraná Basin: Petrogenetic and Geophysical Aspects. Instituto Astronômico e Geofísico. Universidade de São Paulo. p.25-46.

Rubin A.M. \& Pollard D.D. (1987) Origins of blade-like dikes in volcanic rift zones. In Decker R.W., Wright T.L., Stauffer P.H. (Eds.) Volcanism in Hawaii, USGS Professional Paper 1350: 1449-1470.

Sadowski G. R. (1974) Tectônica da Serra de Cubatão, S.P. Tese de Doutorado. Instituto de Geociências. Universidade de São Paulo. 160p.

Sadowski G. R (1987) A possible reJation between pulses of platform activation and plate kinematics. Tectonophysics 43(1-3): 43-57.

Sanford R.M. \& Lange F.W. (1960) Basin study approach to oil evaluation of Paraná miogeosyncline, South Brasil. Bulletin of American Association of Petrolleum Geologist 44 (8): 1316-1370.

Sawamoto H (1977) Orthorhombic perovskite (Mg, Fe) SiO 3 and the constitution of the lower mantle. In: Manghnani MH, Akimoto S (Eds.) High pressure research. New York, Academic Press 350p.

Schettino A., \& Scotese C. R. (2005) Apparent polar wander paths for the major continents (200 Ma Present Day): A paleomagnetic reference frame for global plate tectonic reconstructions, Geophysical Journal International 163(2): 727-759.

Scholz C.H. (1990) The mechanics of earthquakes and faulting. University Press, Cambridge.

Schubert G., Turcotte D., Olson P. (2001) Mantle Convection in the Earth and Planets. Cambridge: Cambridge University Press 940p.

Sears J.W., St. George, G.M., Winne J.C. (2005) Continental rift systems and anorogenic magmatism: Lithos 80(1-4): 147-154.

Şengör A.M.C. \& Burke K. (1978) Relative timing of rifting and volcanism on Earth and its tectonic implications. Geophysical Research Letters 5 (6): 419-421.

Sheth H.C. (1999) Flood basalts and large igneous provinces from deep mantle plumes: fact, ficction and fallacy. Tectonophysics 311:1-29.

Sheth H.C. (2007) 'Large Igneous Provinces (LIPs)': Definition, recommended terminology, and a hierarchical classification, Earth-Science Reviews 85: 117-124.

Sial A.N., Oliveira E.P., Choudhuri A (1987). Mafic dykes swarm of Brazil. Geological Association of Canada, Special paper 34: 467-481.

Sigurdsson H. \& Sparks R.S.J. (1978) Rifting episode in North Iceland in 1874-1875 and the eruptions of Askja and Sveinagja. Bulletin of Volcanology 41: 149-167. 
Silva L.C. (1991) O Cinturão metavulcanossedimentar Brusque e a evolução policíclica das faixas dobradas proterozóicas no Sul do Brasil: uma revisão. Revista Brasileira de Geociências 21(1): 60-73.

Silva T.B. \& Riccomini C. (2005) O uso de corpos intrusivos como indicadores tectônicos: o enxame de diques Santos - Rio de Janeiro. In: $13^{\circ}$ Simpósio Internacional de Iniciação Científica da USP. São Carlos, SP.

Sleep N.H. (1990) Hotspots and mantle plumes; some phenomenology: Journal of Geophysical Research 95: 6715-6736.

Smith R.P. (1987) Dyke emplacement at Spanish Peaks, Colorado. In: Halls H.C., Fahrig W.F. (Eds.), Mafic Dyke Swarms. Geological Association of Canada, St. John, p. 47-54.

Smith A.D. \& Lewis C. (1999) The planet beyond the plume hypothesis. Earth-Science Reviews 48: 135182.

Soares P.C., Luz M.E.R., Redaelli R., Guerra S.M.S. (1982) Análise morfoestrutural em fotos aéreas: aplicação na prospecção de hidrocarbonetos na Bacia do Paraná. In: $2^{\circ}$ Simpósio Brasileiro de Sensoriamento Remoto, Brasília, Resumos, p.157-168.

Stevens B. (1911) The laws of intrusion. Bulletin of the American Institute of Mining Engineers 49: 1-23.

Stevenson O.J. (1989) Spontaneous small-scale melt segregation in partial melts undergoing deformation. Geophysical Research Letters 16:1067- 70

Stewart K., Turner S., Kelley S., Hawkesworth C., Kirstein L., Mantovani M. (1996) 3-D, ${ }^{40}$ Ar- ${ }^{39}$ Ar geochronology in the Paraná continental flood basalt province. Earth Planetary Science Letters 143: 95109.

Stixrude L., Hemley R.J., Fei Y., Mao H. K. (1992) Thermoelasticity of silicate perovskite and magnesiowüstite and stratification of the earth's mantle, Science 257: 1099-1101.

Stüwe K. (2007) Geodynamics of the Lithosphere, 2nd ed. Springer-Verlag, Berlin. $493 \mathrm{p}$.

Suppe J. (1985). Principles of Structural Geology. Prentice-Hall, Englewood Cliffs, N.J., 537 pp.

Tchalenko J.S. (1970) Similarities between shear zones of different magnitudes. Geological Society of American Bulletin 81: 1625-1640.

Tetzner W. (2002) Tectônica, petrologia, geoquímica, e geocronologia dos diques básicos da Região dos Lagos-RJ. Dissertação de mestrado. Universidade do Estado do Rio de Janeiro. 111 pp.

Thiede D.S. \& Vasconcelos P.M. (2010) Paraná flood basalts: Rapid extrusion hypothesis confirmed by new ${ }^{40} \mathrm{Ar} /{ }^{39} \mathrm{Ar}$ results. Geology 38 (8): 747-750.

Thompson G.A. (1998) Deep mantle plumes and geoscience vision. GSA Today 8 (4): $17-25$.

Thompson R.N. \& Gibson S.A. (1991) Subcontinental mantle plumes, hot spots and preexisting thin spots. Journal of Geophysical Research 148: 973-977.

Tokarski A.K. (1990) Dyke swarms as stress indicators: Two constraints. In: Parker A.J., Rickwood P.C., Tucker D.H. (Eds.), Mafic Dykes and Emplacement Mechanisms. A.A. Balkema, Rotterdam, p. 101-104.

Tomazzoli E.R., Pellerin J.R.M. (2008) O Enxame de Diques Florianópolis Na Ilha de Santa Catarina SC: Mapa Geológico. In: Simpósio de Vulcanismo e Ambientes Assossiados, Foz do Iguaçú, Resumos, pág 87. 
Tomba C.L.B. (2006) Tectônica e sedimentação das coberturas triássicas isoladas sobre o Alto Estrutural do Rio Grande na região entre Santana da Boa Vista e Canguçu, RS. Trabalho de Conclusão de Curso. Instituto de Geociências, Universidade de São Paulo.

Tomba C.L.B. \& Sato E.N. (2006) Campos de esforços controladores do enxame de diques máficoultramáfico da ilha de São Sebastião, SP. In: $43^{\circ}$ Congresso Brasileiro de Geologia, Aracaju, Resumos, pág. 272.

Tomba C.L.B. \& Riccomini C. 2008. Indicadores de fluxo magmático e rochas ígneas intrusivas: exemplos do enxame de diques máfico-ultramáfico do litoral norte de São Paulo. In: $12^{\circ}$ Simpósio Nacional de Estudos Tectônicos, Ouro Preto, Resumos, pág. 42

Torsvik T.H., Rousse S., Labails C., Smethurst M.A. (2009) A new scheme for the opening of the South Atlantic Ocean and the dissection of an Aptian salt basin. Geophysical Journal International 177: 13151333.

Turner S., Regelous M., Kelley S., Hawkesworth C. \& Mantovani M. (1994) Magmatism and continental break-up in the South Atlantic high precision 40Ar-39Ar geochronology. Earth and Planetary Science Letters 121: 333-348.

Turner S., Hawkesworth C., Gallagher K., Stewart K., Peate D., Mantovani M. (1996) Mantle plumes, flood basalts, and thermal models for melt generation beneath continents: assessment of conductive heating model and application to the Paraná. Journal of Geophysical Research 101: 11503-11518.

Trindade R.I.F, D'agrella-Filho M.S, Epof I, Brito Neves B.B. (2006) Paleomagnetism of Early Cambrian Itabaiana mafic dikes (NE Brazil) and the final assembly of Gondwana. Earth and Planetary Science Letters 244: 361-377.

Triola M. F. (2005) Introdução à Estatística, 9a ed., LCT.

Valente S.C., Ellam R.L., Meighan I.G., Fallick A.E. (1998) Geoquímica isotópica, modelo geodinâmico e petrogênese dos diabásios do cretácio Inferior no Enxame de Diques Máficos da Serra do Mar (EDSM) na área de do Rio de Janeiro, RJ. In: 40 Congresso Brasileiro de Geologia, Belo Horizonte, Resumos, pág. 471.

Valente S.C., Duarte B.P., Heilbron M., Almeida J.C.H., Valladares C.S., Guedes E., Tetzner W., Lobo J., Corval A., Dutra T., Soares L.H., Souza F.M., Vinha J., Famelli N. 2005. Mapa do Enxame de Diques da Serra do Mar. In: $3^{\circ}$ Simpósio de Vulcanismo e Ambientes Associados, 3, Anais, p. 207-211.

Valente S.C., Corval A., Duarte B.P., Ellam R.M., Fallick A.E., Meighan I.G., Dutra T. (2007) Tectonic boundaries, crustal weakness zones and plume subcontinentallithospheric mantle interactions in the Serra do Mar dyke swarm, SE Brazil. Revista Brasileira de Geociências 37(1): 194-201.

Vieira A.J. (1973) Geologia do centro e nordeste do Paraná e centro-sul de São Paulo. In: $27^{\circ}$ Congresso Brasileiro de Geologia, Aracaju, Resumos (3): 259-277.

Vink G.E. (1982) Continental rifting and the implications for plate tectonic reconstructions. Journal of Geophysical Research 87: 10677-10688.

Wildner W., Brito R.S.C., Licht O.A.B., Arioli E. (2006) Geologia e Recursos Minerais do Estado do Paraná. CPRM/MINEROPAR. 95p.

Wilson J.T. (1963) A possible origin of the Hawaiian Islands. Canadian Journal of Physics 41: 863-868.

Wilson M. (1989) Igneous petrogenesis. A global tectonic approach. Springer. 466p.

Winter R.W., Jahnert R.J., França A.B. (2007) Bacia de Campos. Boletim de Geociências da Petrobras 15(2): 511-530. 
White I. C. (1908) Relatório sobre as coal measures e rochas associadas ao sul do Brasil. Rio de Janeiro, Comissão das Minas e carvão de Pedra do Brasil, 300 p.

White R.S. \& McKenzie D.P. (1989). Magmatism at rift zones: the generation of volcanic continental margins and flood basalts. Journal of Geophysical Research 94: 7685-7729.

White R.S. \& McKenzie D.M. (1995) Mantle plumes and flood basalts. Journal of. Geophysical. Research 100B9: 17543-17585.

Zalán P.V. (2004) Evolução fanerozóica das bacias sedimentares brasileiras. In V. Mantesso-Neto V., Bartorelli A., Carneiro C.D.R., Brito-Neves B.B. (Coords.). Geologia do continente sul-americano. Evolução da obra de Fernando Flávio Marques de Almeida, São Paulo: Ed. Beca, 245-263.

Zalán P.V., Wolff S., Astolfi M.A.M., Vieira I.S., Conceição J.C.J., Appi V.T., Neto E.V.S, Cerqueira J.R., Marques A. (1990) The Paraná Basin, Brazil. In: Interior Cratonic Basins. Bulletin of the American Association of Petroleum Geologists, Memoir 51: 681-707.

Zoback M.L., Zoback M.D., Adams J., Assumpçao M., Bell S., Beegman E.A., Blüming P., Brereton N.R., Denham D., Ding J., Fuchs K., Gay N., Gregersen S., Gupta H.K., Gvishiani A., Jacob K., Klein R., Knoll P., Magee M., Mercier J.L., Müller B.C., Paquin C., Rajendran K., Stephansson O., Suarez G., Suter M., Udías A., Xu Z.H. \& Zhzhin M. (1989) Global pattern of tectonic stress. Nature 341:291-298.

Zoback M.L. (1992) First and second-order patterns of stress in the lithosphere: the World Stress map project. Journal of Geophysical Research 97B:11703-11728. 